Prepared in cooperation with the State of Hawaii Department of Health

\title{
Suspended-Sediment and Nutrient Loads for Waiakea and Alenaio Streams, Hilo, Hawaii, 2003-2006
}
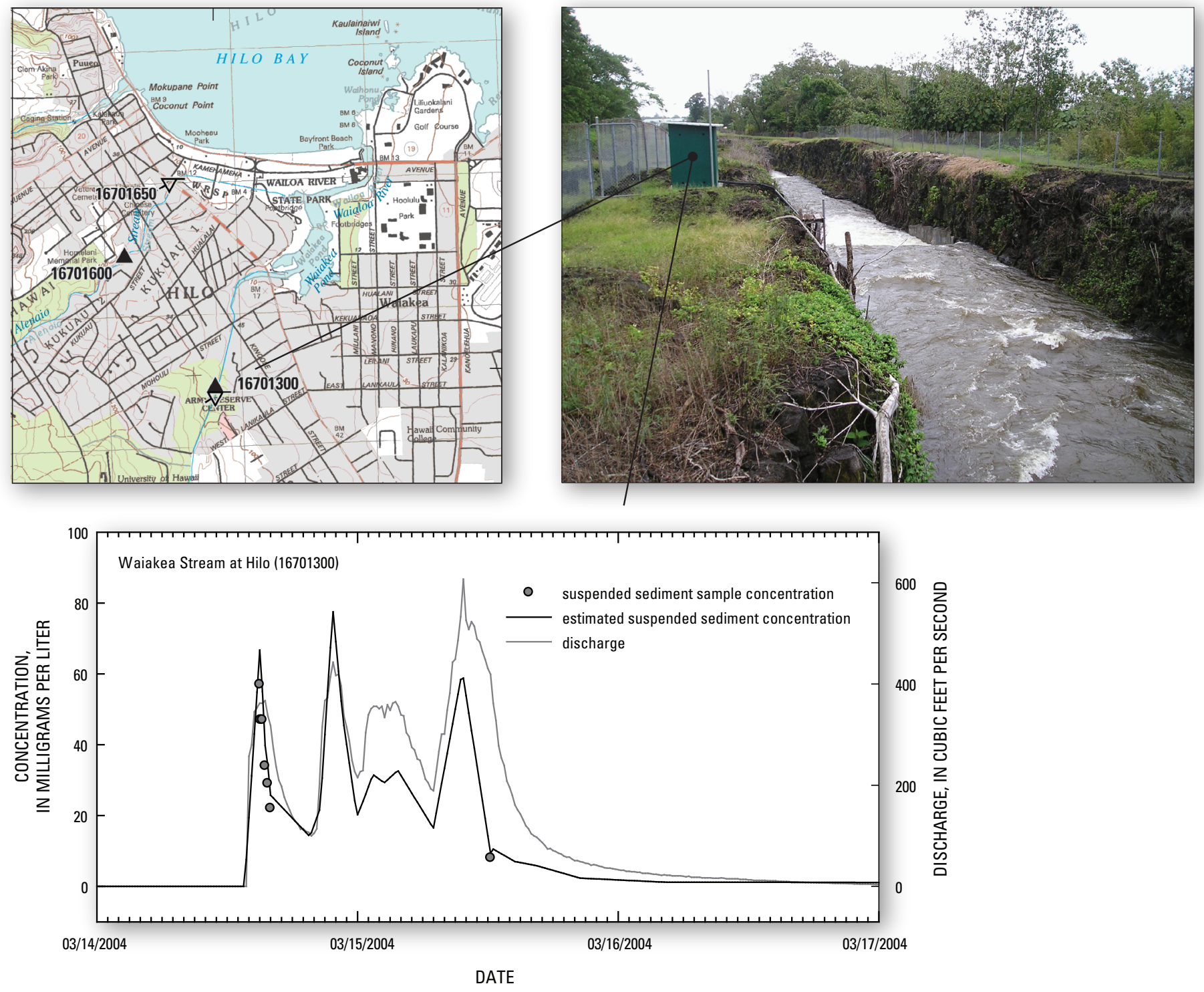

Open-File Report 2007-1429 
This page intentionally left blank 


\section{Suspended-Sediment and Nutrient Loads for Waiakea and Alenaio Streams, Hilo, Hawaii, 2003-2006}

By Todd K. Presley, Marcael T.J. Jamison, and Dale C. Nishimoto

Prepared in cooperation with the State of Hawaii Department of Health

Open-File Report 2007-1429 


\section{U.S. Department of the Interior DIRK KEMPTHORNE, Secretary}

\section{U.S. Geological Survey \\ Mark D. Myers, Director}

\section{U.S. Geological Survey, Reston, Virginia: 2008}

For product and ordering information:

World Wide Web: http://www.usgs.gov/pubprod

Telephone: 1-888-ASK-USGS

For more information on the USGS--the Federal source for science about the Earth, its natural and living resources, natural hazards, and the environment:

World Wide Web: http://www.usgs.gov

Telephone: 1-888-ASK-USGS

Any use of trade, product, or firm names is for descriptive purposes only and does not imply endorsement by the U.S. Government.

Although this report is in the public domain, permission must be secured from the individual copyright owners to reproduce any copyrighted materials contained within this report.

Suggested citation:

Presley, T.K., Jamison, M.T.J, and Nishimoto, D.C., 2008, Suspended-sediment and nutrient loads for Waiakea and Alenaio Streams, Hilo, Hawaii, 2003-2006: Honolulu, Hawaii, U.S. Geological Survey Open-File Report 2007-1429, $73 \mathrm{p}$. 


\section{Contents}

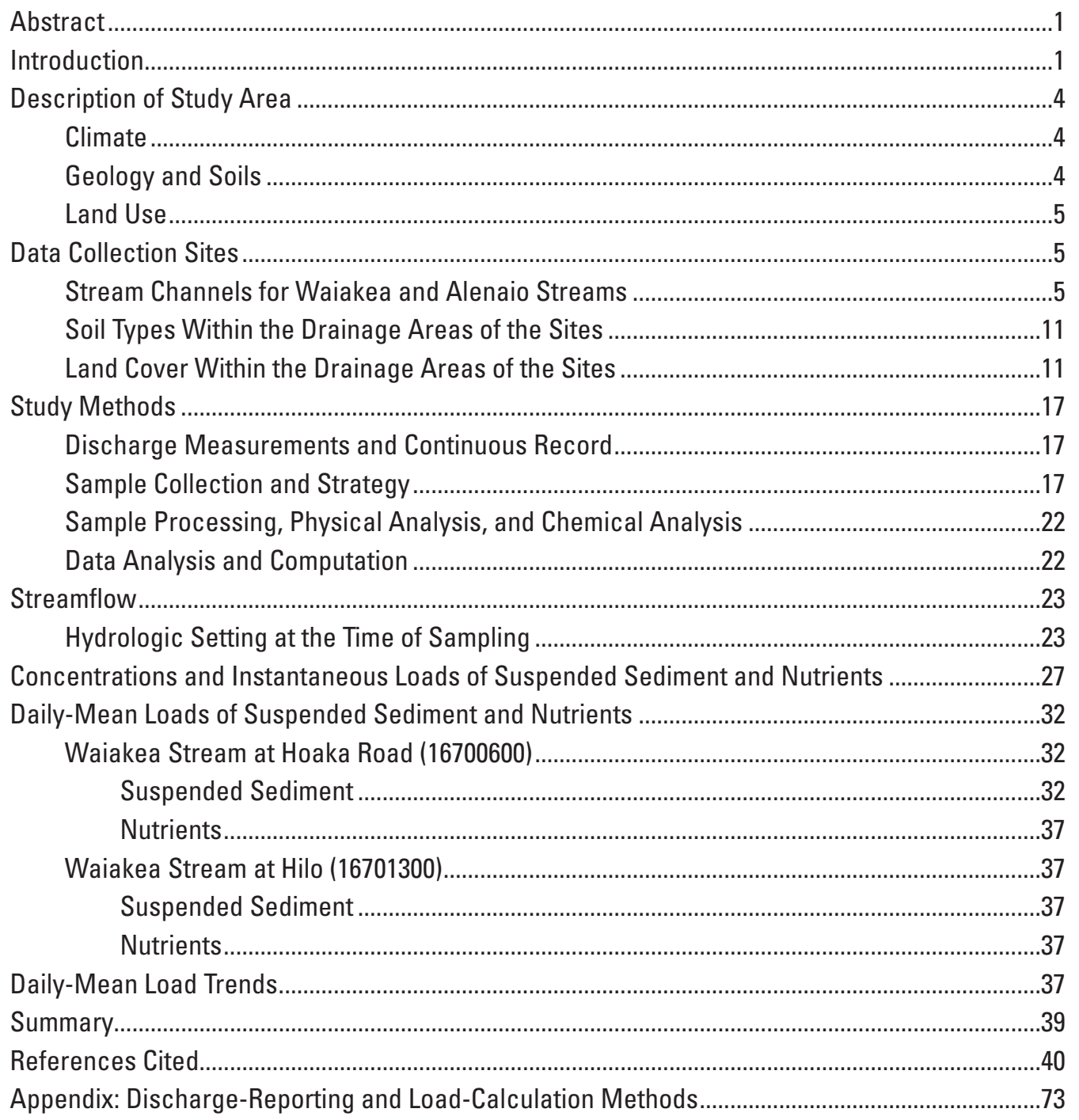




\section{Figures}

1. Map showing rain gages, stream-gaging sites, and stream-sampling sites used in this study, and the Waiakea and Alenaio drainage basins, Hilo area, Hawaii..................2

2. Map showing stream-gaging sites and water-quality sites used for this study, Hilo, Hawaii.

3. Photographs of sampling site and gage at Waiakea Stream at Hoaka Road (16700600), (A) looking downstream and (B) looking upstream, October 27, 2003, Hilo, Hawaii.

4. Photographs of sampling site and gage Waiakea Stream at Hilo (16701300), $(A)$ looking upstream, and $(B)$ looking downstream, on March 9, 2006, Hilo, Hawaii .7

5. Photographs of sampling site and gage Alenaio Stream at Kilauea Avenue Bridge (16701650), $(A)$ gage house and sampling line, $(B)$ staff plate and $(C)$ standing wave downstream of gage, on March 9, 2006, Hilo, Hawaii

6. Photographs of sampling site and gage at Alenaio Stream at Hilo (16701600), $(A)$ looking downstream during flow on March 9, 2006, $(B)$ looking downstream from gage during dry conditions on 0 ctober 13,2006 , and $(C)$ looking downstream from upstream location, Hilo, Hawaii

7. Photograph of Waiakea Stream flood control work near West Kawailani Street, January 11, 2005, Hilo, Hawaii

8. Map showing soil hydrologic groups and soil erodibility factors within drainage areas of stream-gaging and sampling sites for this study, Hilo, Hawaii.

9. Map showing land cover classes within drainage areas of stream-gaging and sampling sites for this study, Hilo, Hawaii

10. Daily-mean discharge for sites Waiakea Stream at Hoaka Road (16700600), Waiakea Stream at Hilo (16701300), and Alenaio Stream at Hilo (16701600), Hilo, Hawaii; October 1, 2003, to September 30, 2006

11. Discharge, suspended sediment sample concentration, estimated suspended sediment concentration, and discharge for Waiakea Stream at Hilo (16701300), Hilo, Hawaii, during March 1 to June 1, 2004, and detail of March 14 to March 17, 2004 ......25

12. Discharge at Alenaio Stream at Hilo (16701600) and discharge measurements made at Alenaio Stream at Kilauea Avenue Bridge (16701650), during November 9, 2005, January 26, 2006, and March 9, 2006, Hilo, Hawaii .

13. Daily-mean discharge for sites Waiakea Stream at Hoaka Road (16700600), Waiakea Stream at Hilo (16701300), Alenaio Stream at Hilo (16701600), Wailuku River at Piihonua (16704000), and Honolii Stream near Papaikou (1671700, Hilo, Hawaii; October 1, 2003, to September 30, 2005.

14. Monthly rainfall, as percent departure from mean-monthly rainfall, for three National Weather Service raingages in or near study area; discharge at gaging station Honolii Stream near Papaikou (16717000), with band delineating 25th and 75th percentile flow, and sampling dates for suspended sediment and nutrients at study sites, during 2003 to 2006, Hilo, Hawaii..

15. Daily-mean loads of suspended sediment and nutrients at Waiakea Stream at Hoaka Road (16700600), Hilo, Hawaii: (A) October 1, 2003, to September 30, 2004, (B) October 1, 2004, to September 30, 2005. 
16. Daily-mean loads of suspended sediment and nutrients at Waiakea Stream at Hilo (16701300), Hilo, Hawaii: (A) October 1, 2003, to September 30, 2004, (B) October 1, 2004, to September 30, 2005.

17. Daily-mean concentration and load for suspended sediment and total nitrogen, and daily-mean discharge, for sites Waiakea Stream at Hoaka Road (16700600) and Waiakea Stream at Hilo (16701300) during early March 2004, Hilo, Hawaii .

18. Daily-mean concentration and load for suspended sediment and total nitrogen, and daily-mean discharge, for sites Waiakea Stream at Hoaka Road (16700600) and Waiakea Stream at Hilo (16701300) during early February and late March 2005, Hilo, Hawaii.

19. Daily-mean concentration and load for suspended sediment, and daily-mean discharge, for sites Waiakea Stream at Hoaka Road (16700600) and Waiakea Stream at Hilo (16701300) during early August 2005, Hilo, Hawaii..

\section{Tables}

1. Sampling sites, drainage area, types of data collected, and general land use above sites on Waiakea and Alenaio Streams, Hilo, Hawaii

2. Descriptions of stream channels for Waiakea and Alenaio Streams, based on distance and altitude, Hilo, Hawaii.

3. Areas and percentages of soil map units within drainage areas of sites used in study, Hilo Hawaii

4. Areas and percentages of NOAA C-CAP land cover classes within drainage areas of sites used in study, Hilo Hawaii.

5. Chronology of data collection, number of days samples were collected, number of samples collected, and number storm events at sites on Waiakea and Alenaio Streams, Hilo, Hawaii.

6. Number of samples used, number of estimates used, cross-section coefficient values, and transport curve equations used for estimating daily-mean load records at Waiakea Stream at Hoaka Road (16700600) and Waiakea Stream at Hilo (16701300), during water years 2004 and 2005.

7. Altitude, drainage area, and period of record for additional stream gaging stations and National Weather Service rain gages presented in this report, Hilo, Hawaii

8. Discharge, concentration and instantaneous loads of suspended sediment, for samples collected without associated nutrient analyses, from March 15, 2004, to August 7, 2005, Waiakea Stream at Hoaka Road (16700600), Hilo, Hawaii .....

9. Discharge, concentration and instantaneous loads of nutrients and suspended sediment samples collected from March 14, 2004, to March 30, 2005, Waiakea Stream at Hoaka Road (16700600), Hilo, Hawaii .

10. Discharge, concentration and instantaneous loads of suspended sediment, for samples collected without associated nutrient analyses, from March 15, 2004, to August 7, 2005, Waiakea Stream at Hilo (16701300), Hilo, Hawaii

11. Discharge, concentration and instantaneous loads of nutrients and suspended sediment for samples collected from March 14, 2004, to March 30, 2005, Waiakea Stream at Hilo (16701300), Hilo, Hawaii. 
12. Discharge, concentration and instantaneous loads of suspended sediment, for samples collected without associated nutrient analyses, from November 9, 2005, to January 26, 2006, Alenaio Stream at Kilauea Avenue Bridge (16701650), Hilo, Hawaii

13. Discharge, concentration and instantaneous loads of nutrients and suspended sediment for samples collected from November 9, 2005, to March 9, 2006, Alenaio Stream at Kilauea Avenue Bridge (16701650), Hilo, Hawaii.

14. Statistical summary of discharge, suspended sediment and nutrient concentrations, and instaneous loads, for Waiakea Stream at Hoaka Road, Waiakea Stream at Hilo, and Alenaio Stream at Kilauea Avenue Bridge, Hilo, Hawaii.

15A. Daily-mean loads of suspended sediment during October 1, 2003, to September 30, 2004, Waiakea Stream at Hoaka Road (1670600), Hilo, Hawaii .... .51

15B. Daily-mean loads of suspended sediment during October 1, 2004, to September 30, 2005, Waiakea Stream at Hoaka Road (1670600), Hilo, Hawaii

16A. Daily-mean loads of total nitrogen during October 1, 2003, to September 30, 2004, Waiakea Stream at Hoaka Road (1670600), Hilo, Hawaii

16B. Daily-mean loads of total nitrogen during October 1, 2004, to September 30, 2005, Waiakea Stream at Hoaka Road (1670600), Hilo, Hawaii

17A. Daily-mean loads of nitrogen, nitrite plus nitrate, dissolved, during 0 ctober 1, 2003, to September 30, 2004, Waiakea Stream at Hoaka Road (1670600), Hilo, Hawaii ................55

17B. Daily-mean loads of nitrogen, nitrite plus nitrate, dissolved, during October 1, 2004, to September 30, 2005, Waiakea Stream at Hoaka Road (1670600), Hilo, Hawaii ................56

18A. Daily-mean loads of total phosphorus during October 1, 2003, to September 30, 2004, Waiakea Stream at Hoaka Road (1670600), Hilo, Hawaii ....

18B. Daily-mean loads of total phosphorus during October 1, 2004, to September 30, 2005, Waiakea Stream at Hoaka Road (1670600), Hilo, Hawaii

19A. Daily-mean discharge during October 1, 2003, to September 30, 2004, Waiakea Stream at Hoaka Road (1670600), Hilo, Hawaii.

19B. Daily-mean discharge during October 1, 2004, to September 30, 2005, Waiakea Stream at Hoaka Road (1670600), Hilo, Hawaii.

19C. Daily-mean discharge during October 1, 2005, to September 30, 2006, Waiakea Stream at Hoaka Road (1670600), Hilo, Hawaii

20A. Daily-mean loads of suspended sediment during October 1, 2003, to September 30, 2004, Waiakea Stream at Hilo (16701300), Hilo, Hawaii.

20B. Daily-mean loads of suspended sediment during October 1, 2004, to September 30, 2005, Waiakea Stream at Hilo (16701300), Hilo, Hawaii.

21A. Daily-mean loads of total nitrogen during October 1, 2003, to September 30, 2004, Waiakea Stream at Hilo (16701300), Hilo, Hawaii..

21B. Daily-mean loads of total nitrogen during October 1, 2004, to September 30, 2005, Waiakea Stream at Hilo (16701300), Hilo, Hawaii..

22A. Daily-mean loads of nitrogen, nitrite plus nitrate, dissolved, during October 1, 2003, to September 30, 2004, Waiakea Stream at Hilo (16701300), Hilo, Hawaii.

22B. Daily-mean loads of nitrogen, nitrite plus nitrate, dissolved, during October 1, 2004, to September 30, 2005, Waiakea Stream at Hilo (16701300), Hilo, Hawaii

23A. Daily-mean loads of total phosphorus during October 1, 2003, to September 30, 2004, Waiakea Stream at Hilo (16701300), Hilo, Hawaii.

23B. Daily-mean loads of total phosphorus during October 1, 2004, to September 30, 2005, Waiakea Stream at Hilo (16701300), Hilo, Hawaii. 
24A. Daily-mean discharge during October 1, 2003, to September 30, 2004, Waiakea Stream at Hilo (16701300), Hilo, Hawaii ...........................................................................................70

24B. Daily-mean discharge during October 1, 2004, to September 30, 2005, Waiakea Stream at Hilo (16701300), Hilo, Hawaii ........................................................................................... 71

24C. Daily-mean discharge during October 1, 2005, to September 30, 2006, Waiakea Stream at Hilo (16701300), Hilo, Hawaii ...................................................................................... 72

\section{Conversion Factors}

Inch/Pound to SI

\begin{tabular}{lll}
\hline \multicolumn{1}{c}{ Multiply } & \multicolumn{1}{c}{ By } & \multicolumn{1}{c}{ To obtain } \\
\hline inch (in.) & Length & \\
foot (ft) & 2.54 & centimeter $(\mathrm{cm})$ \\
mile (mi) & 0.3048 & meter $(\mathrm{m})$ \\
\hline & 1.609 & kilometer $(\mathrm{km})$ \\
\hline cubic foot per second $\left(\mathrm{ft}^{3} / \mathrm{s}\right)$ & Flow rate & \\
\hline & 0.02832 & cubic meter per second $\left(\mathrm{m}^{3} / \mathrm{s}\right)$ \\
\hline cubic foot $\left(\mathrm{ft}^{3}\right)$ & Volume & liter $(\mathrm{L})$ \\
\hline & 28.3178 & \\
\hline pounds per day (lbs/day) & Load & tons per year (tons/yr)
\end{tabular}

Temperature in degrees Celsius $\left({ }^{\circ} \mathrm{C}\right)$ may be converted to degrees Fahrenheit $\left({ }^{\circ} \mathrm{F}\right)$ as follows:

${ }^{\circ} \mathrm{F}=\left(1.8 x^{\circ} \mathrm{C}\right)+32$

Vertical coordinate information is referenced relative to mean sea level.

Horizontal coordinate information is referenced to NAD 83 unless otherwise stated.

Concentrations of chemical constituents in water are given either in milligrams per liter (mg/L) or micrograms per liter ( $\mu \mathrm{g} / \mathrm{L})$.

Specific conductance is given in microsiemens per centimeter at 25 degrees Celsius ( $\mu \mathrm{S} / \mathrm{cm}$ at $\left.25^{\circ} \mathrm{C}\right)$. 
This page intentionally left blank 


\title{
Suspended-Sediment and Nutrient Loads for Waiakea and Alenaio Streams, Hilo, Hawaii, 2003-2006
}

\author{
By Todd K. Presley, Marcael T.J. Jamison, and Dale C. Nishimoto
}

\section{Abstract}

Suspended sediment and nutrient samples were collected during wet-weather conditions at three sites on two ephemeral streams in the vicinity of Hilo, Hawaii during March 2004 to March 2006. Two sites were sampled on Waiakea Stream at 80- and 860-foot altitudes during March 2004 to August 2005. One site was sampled on Alenaio Stream at 10-foot altitude during November 2005 to March 2006. The sites were selected to represent different land uses and land covers in the area. Most of the drainage area above the upper Waiakea Stream site is conservation land. The drainage areas above the lower site on Waiakea Stream, and the site on Alenaio Stream, are a combination of conservation land, agriculture, rural, and urban land uses.

In addition to the sampling, continuous-record streamflow sites were established at the three sampling sites, as well as an additional site on Alenaio Stream at altitude of 75 feet and 0.47 miles upstream from the sampling site. Stage was measured continuously at 15-minute intervals at these sites. Discharge, for any particular instant, or for selected periods of time, were computed based on a stage-discharge relation determined from individual discharge measurements. Continuous records of discharge were computed at the two sites on Waiakea Stream and the upper site on Aleniao Stream. Due to non-ideal hydraulic conditions within the channel of Alenaio Stream, a continuous record of discharge was not computed at the lower site on Alenaio Stream where samples were taken.

Samples were analyzed for suspended sediment, and the nutrients total nitrogen, dissolved nitrite plus nitrate, and total phosphorus. Concentration data were converted to instantaneous load values: loads are the product of discharge and concentration, and are presented as tons per day for suspended sediment or pounds per day for nutrients. Daily-mean loads were computed by estimating concentrations relative to discharge using graphical constituent loading analysis techniques. Daily-mean loads were computed at the two Waiakea Stream sampling sites for the analyzed constituents, during the period October 1, 2003 to September 30, 2005. No record of dailymean load was computed for the Alenaio Stream sampling site due to the problems with computing a discharge record.
The maximum daily-mean loads for the upper site on Waiakea Stream for suspended sediment was 79 tons per day, and the maximum daily-mean loads for total nitrogen, dissolved nitrite plus nitrate, and total phosphorus were 1,350, 13, and 300 pounds per day, respectively. The maximum daily-mean loads for the lower site on Waiakea Stream for suspended sediment was 468 tons per day, and the maximum daily-mean loads for total nitrogen, nitrite plus nitrate, and total phosphorus were 913, 8.5, and 176 pounds per day, respectively. From the estimated continuous daily-mean load record, all of the maximum daily-mean loads occurred during October 2003 and September 2004, except for suspended sediment load for the lower site, which occurred on September 15, 2005. Maximum values were not all caused by a single storm event. Overall, the record of daily-mean loads showed lower loads during storm events for suspended sediments and nutrients at the downstream site of Waiakea Stream during 2004 than at the upstream site. During 2005, however, the suspended sediment loads were higher at the downstream site than the upstream site. Construction of a flood control channel between the two sites in 2005 may have contributed to the change in relative suspended-sediment loads.

\section{Introduction}

The Hawaii Department of Health $(\mathrm{HDOH})$ has the responsibility under the federal Clean Water Act to establish total maximum daily loads (TMDLs) for waterbodies on the Hawaii 303(d) list of impaired waterbodies (HDOH, 2004). Five streams that discharge into Hilo Bay on the island of Hawaii have been identified as impaired owing to high levels of sediment and nutrients: Wailoa, Waiakea, Alenaio, Wailuku, and Honolii streams (fig. 1). In order to assist with the preparation of a TMDL analysis for these streams, the $\mathrm{HDOH}$ and the U.S. Geological Survey (USGS) entered into a cooperative agreement to collect streamflow and water-quality data to determine suspended-sediment and nutrient loads at selected locations along two streams that discharge into Hilo Bay: Waiakea and Alenaio Streams (figs. 1 and 2). 


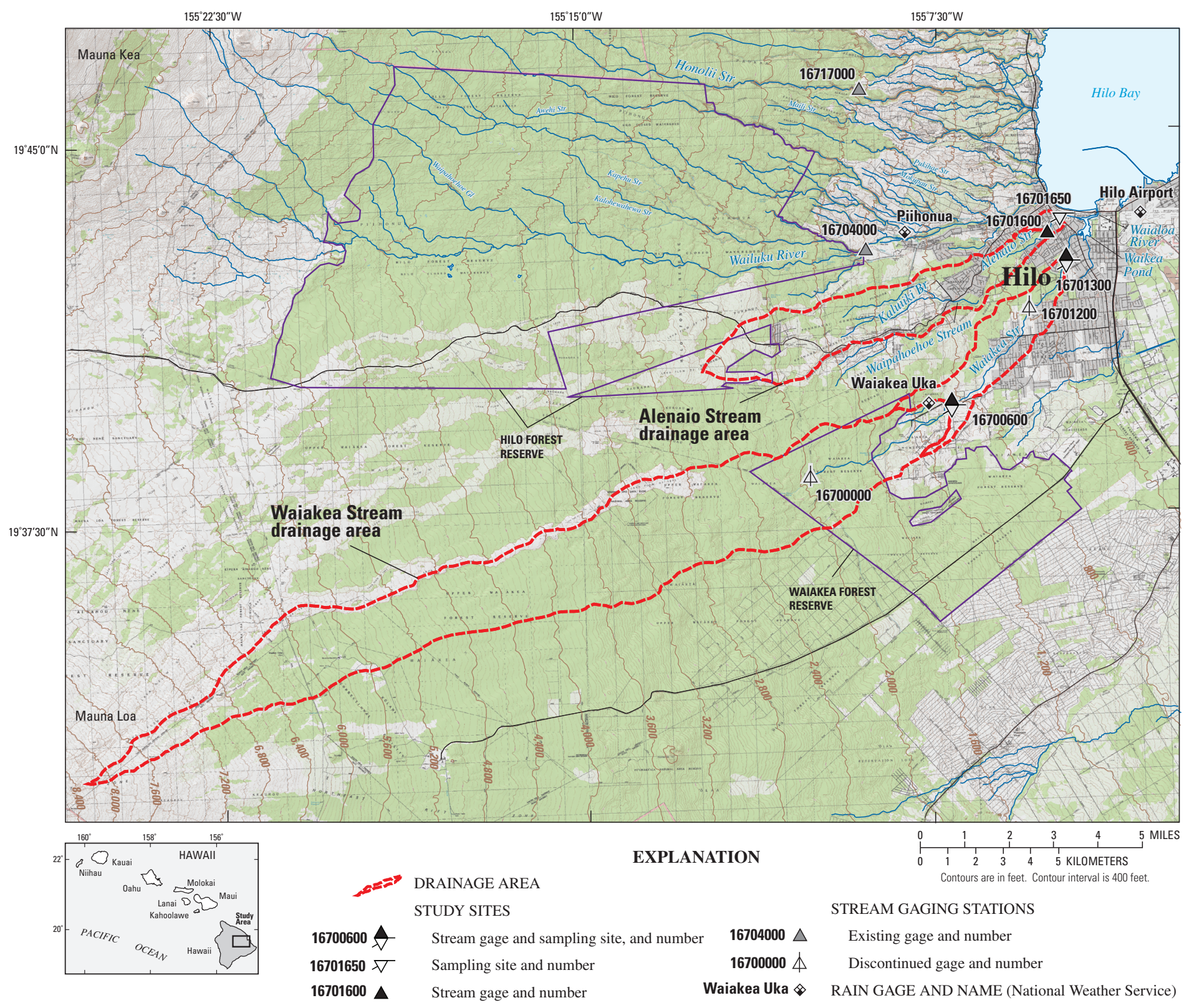

Figure 1. Map showing rain gages, stream-gaging sites, and stream-sampling sites used in this study, and the Waiakea and Alenaio drainage basins, Hilo area, Hawaii. 


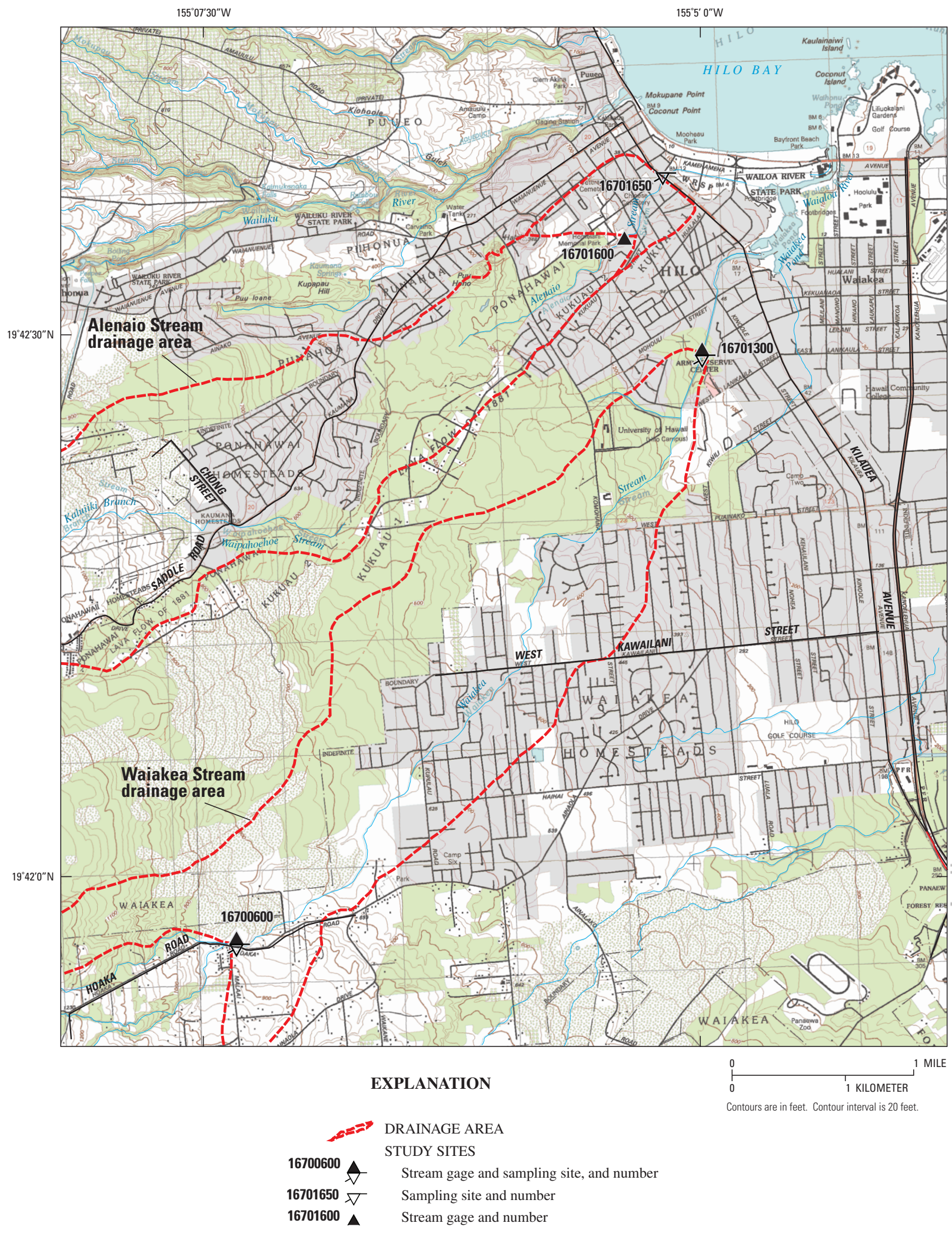

Figure 2. Map showing stream-gaging sites and water-quality sites used for this study, Hilo, Hawaii. 
Stream load is a measure of the amount of constituent delivered by the stream, in pounds (lbs) or tons, divided over a period of time, in days. In order to calculate loads, the concentration of the constituent, in milligrams per liter $(\mathrm{mg} / \mathrm{L})$ or other concentration unit, is multiplied by discharge in cubic feet per second (cfs), and a conversion factor. Concentration data can be estimated to create a continuous record, and is based on the concentration of samples and a continuous record of discharge. Daily-mean loads are the mean of the unit-value loads for a given day, derived from the concentrations of samples and unit-value estimates of concentration multiplied by the corresponding unit-value discharge data.

This report presents streamflow, suspended sediment, and nutrient data collected on these two streams. Two sites were sampled on Waiakea Stream during March 2004 to August 2005 and one site on Alenaio Stream during November 2005 to March 2006. The site locations on each stream were selected in an effort to relate suspended-sediment and nutrient loads to different geographical areas, based on land use / land cover characteristics within the drainage areas. Percentages of land cover and soil type in the drainage areas of the sampling sites are presented. Continuous-record discharge data for the two Waiakea Stream sites are presented; however, due to difficulties developing a stage / discharge relation for the Alenaio Stream sampling site, no continuous-record discharge data for this site is presented. A second Alenaio Stream site, 0.47 miles (mi) upstream, was established to measure discharge only in lieu of the record at the lower site. Discharge data at this upstream site were collected concurrently with the sampling at the lower site.

Instantaneous loads were calculated for constituents analyzed in samples from all three sites, and daily-mean loads were calculated for the two sites on Waiakea Stream. Dailymean loads could not be determined for the Alenaio Stream sampling site due to the difficulties of computing a record of discharge at that site.

The assistance and support of the State of Hawaii Department of Health is gratefully acknowledged. Special thanks to Dave Penn and Glen Fukunaga, for thorough review comments and supplementing the report with land cover and soil cover maps and data. David Bishaw, an intern with $\mathrm{HDOH}$, assisted with site construction and sampling. The project was funded through a grant from the U.S. Environmental Protection Agency to the State of Hawaii Department of Health.

\section{Description of Study Area}

The study area includes the watersheds of Waiakea and Alenaio Streams on the island of Hawaii. These two watersheds drain a combined area of about 44.6 square miles $\left(\mathrm{mi}^{2}\right)$ on the windward (northeast) slope of the Mauna Loa Volcano (fig. 1). Both streams drain into the Wailoa River, which empties into Hilo Bay, the major harbor for the island. Drainage areas are from drainage area maps housed at the USGS Pacific
Islands Water Science Center, and are based on field observations and the study of topography adjacent to the stream channel.

Terrain within the study area is mostly uniform slopes with poorly dissected stream channels. Altitudes within the study area range from sea level to about 8,680 feet (ft) above sea level for the Waiakea Stream drainage area, and about 2,530 $\mathrm{ft}$ above sea level for the Aleniao Stream drainage area.

\section{Climate}

The climate of the study area is warm and humid. At higher altitudes, especially at the summits of the high volcanoes, temperatures vary seasonally to a greater extent than at lower altitudes (Giambelluca and Schroeder, 1998). Rainfall is highly variable across space and time, and is greatly affected by the prevailing northeast trade winds, orographic effects of Mauna Loa and Mauna Kea, and inversion layer dynamics. Mean-annual rainfall ranges from 118 inches per year (in/ yr) along the coast to over $236 \mathrm{in} . / \mathrm{yr}$ at altitudes near 2,500 ft west-northwest of Hilo on the slopes of Mauna Kea (Giambelluca and others, 1986). Above 2,500 ft, mean annual rainfall decreases to about 39 in. at 8,600-ft altitude, and about 20 in. per year at the summits of Mauna Kea and Mauna Loa, which have altitudes over 13,000 ft. Rainfall occurs year-round, but major storms are more common between November and April than during the rest of the year (Giambelluca and others, 1986).

\section{Geology and Soils}

The exposed rocks in the study area include lava flows from Mauna Loa Volcano and ash deposits of unknown origin. Basaltic aa and pahoehoe lava flows of the Kau Basalt, and Pahala Ash are exposed in the study area. Underlying the Kau Basalt and Pahala Ash are basaltic flows of the Kahuku Basalt (Wolfe and Morris, 1996; Stearns and Macdonald, 1946).

Soils within the study area are generally thin or non existent due to the young age of Mauna Loa Volcano. Within the upper areas of the study area, the lava flows have little or no soil. Lava flows, stony land, and rock land account for 22.01 percent of the total surface throughout the study area. Soils, where present, are predominantly Histosols (organic soils with a high organic matter content in the surface horizon) with some Andisols (derived from volcanic ash, with high water-holding capacity and the ability to fix large quantities of phosphorus). Surface permeability values for these soils range from slow to rapid (2.0 to 20 inches per hour), runoff ranges from very slow to medium, and erosion hazard ranges from slight to moderate (Sato and others, 1973). 


\section{Land Use}

Land use in the study area, in general sense, can be divided into four categories: conservation (forest reserves), agriculture, rural, and urban. Conservation areas above an altitude of roughly $1,500 \mathrm{ft}$ in the Waiakea and Alenaio drainage areas include parts of the Hilo and Waiakea Forest Reserves. These reserves include both native and introduced forest trees, and include small areas used for planting and harvesting within the past 10 years. Most of the Waiakea Stream drainage area (fig. 1) below an altitude of 1,500 ft was used for cultivation of sugar cane from approximately 1880 to 1995 . Since 1995, some of the former sugar fields have been used for pasture, diversified agriculture and low/medium density residences. Other agricultural areas have been left fallow and are overgrown with exotic grasses and shrubs. Light urban development is confined below an altitude of $800 \mathrm{ft}$, although in recent years, development has expanded into higher areas. Higher density residential and urban development predominates below $300 \mathrm{ft}$ in the vicinity of Hilo.

\section{Data Collection Sites}

Four data collection sites were located and established within the study area based on: 1) upstream land use and land cover, and 2) suitability, in a hydraulic sense, for measuring discharge. Two sampling and discharge measurement sites were located on Waiakea Stream, and one site was located on Alenaio Stream (figs. 1and 2, table 1). The site Waiakea Stream at Hoaka Road (station number 16700600, fig. 3) was located near the forest reserve boundary (fig. 1). The site Waiakea Stream at Hilo (station number 16701300, fig. 4) was about 4.65 mi downstream of Waiakea Stream at Hoaka Road, about 1.60 mi upstream from the mouth of Wailoa River, and was near the campus of the University of Hawaii at Hilo (fig. 2).
The site Alenaio Stream at Kilauea Avenue Bridge (station number 16701650, fig. 5) was located in downtown Hilo (fig. 2). A fourth site, Alenaio Stream at Hilo (station number 16701600, fig. 6) was located about 0.47 mi upstream of Alenaio Stream at Kilauea Avenue Bridge, and was established to measure discharge only.

\section{Stream Channels for Waiakea and Alenaio Streams}

Both Waiakea and Alenaio Streams eventually flow into Wailoa River. Waiakea Stream flows first into an estuarine area and a water body called Waiakea Pond, which is directly connected to Wailoa River. Alenaio Stream flows into the Waialama Canal prior to flowing into Wailoa River. The flat area containing Waialama Canal, Waiakea Pond, Wailoa River, and a large park, serves as a flood control area and a buffer zone for tsunami waves (fig. 2).

Both Waiakea and Alenaio Streams have had substantial modification in the lower reaches within the Hilo area, and have channels that loose flow in the reaches above the Hilo area. Streams in the vicinity of Hilo have been modified primarily for flood control, and have fortified walls, straightened channels, or concrete linings. At higher altitudes, some of the streams may disappear and reappear due to interaction with lava tubes and other volcanic features found in the lavas of Mauna Loa, and some reaches of the streams loose substantial flow if their course is over permeable lavas. Distances and altitudes of features in the stream channels of Waiakea and Alenaio Streams are described in table 2.

Waiakea Stream.-Above Waiakea Pond, Waiakea Stream is a concrete-lined channel for about $0.22 \mathrm{mi}$ upstream from the pond. Above the channelized reach of stream, the channel bottom is natural, with the walls of the channel either natural, or rock and concrete lined, to about $3.88 \mathrm{mi}$ upstream of the Wailoa River mouth. The sampling and stream gage site Waiakea Stream at Hilo is within this section of stream

Table 1. Sampling sites, drainage area, types of data collected, and general land use above sites on Waiakea and Alenaio Streams, Hilo, Hawaii.

[mi ${ }^{2}$, square miles]

\begin{tabular}{|c|c|c|c|c|}
\hline Station number & Station name & $\begin{array}{l}\text { Drainage } \\
\text { area } \\
\text { (mi2) }\end{array}$ & Data collected & General upstream land use \\
\hline 16700600 & $\begin{array}{l}\text { Waiakea Stream at Hoaka } \\
\text { Road }\end{array}$ & 31.82 & $\begin{array}{l}\text { Discharge, suspended sediment, } \\
\text { nutrients }\end{array}$ & Conservation and agriculture \\
\hline 16701300 & Waiakea Stream at Hilo & 35.87 & $\begin{array}{l}\text { Discharge, suspended sediment, } \\
\text { nutrients }\end{array}$ & $\begin{array}{l}\text { Conservation, agriculture, rural, } \\
\text { and urban }\end{array}$ \\
\hline 16701600 & Alenaio Stream at Hilo & 8.50 & Discharge & Conservation, agriculture, and rural \\
\hline 16701650 & $\begin{array}{l}\text { Alenaio Stream at Kilauea } \\
\text { Avenue Bridge }\end{array}$ & 8.77 & Suspended sediment, nutrients & $\begin{array}{l}\text { Conservation, agriculture, rural, } \\
\text { and urban }\end{array}$ \\
\hline
\end{tabular}




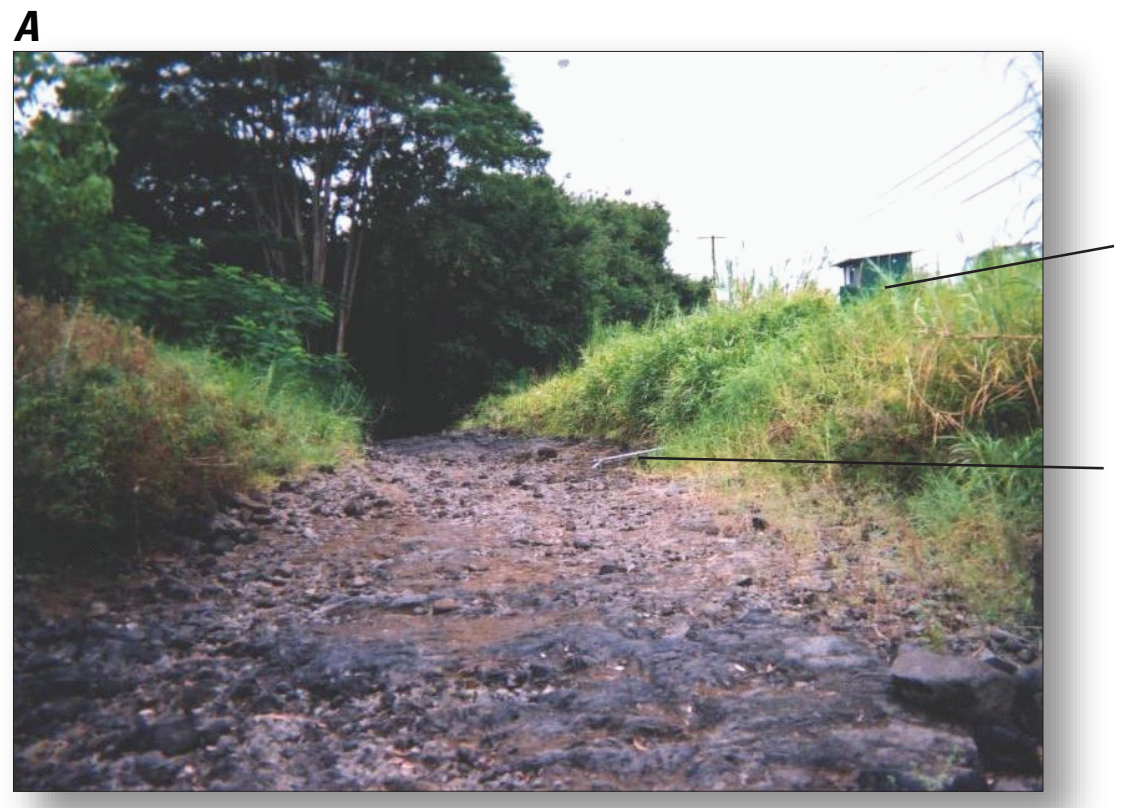

Gage house with autosampler

Pipe containing sampler tube and stream gage stage sensor

\section{$\boldsymbol{B}$}

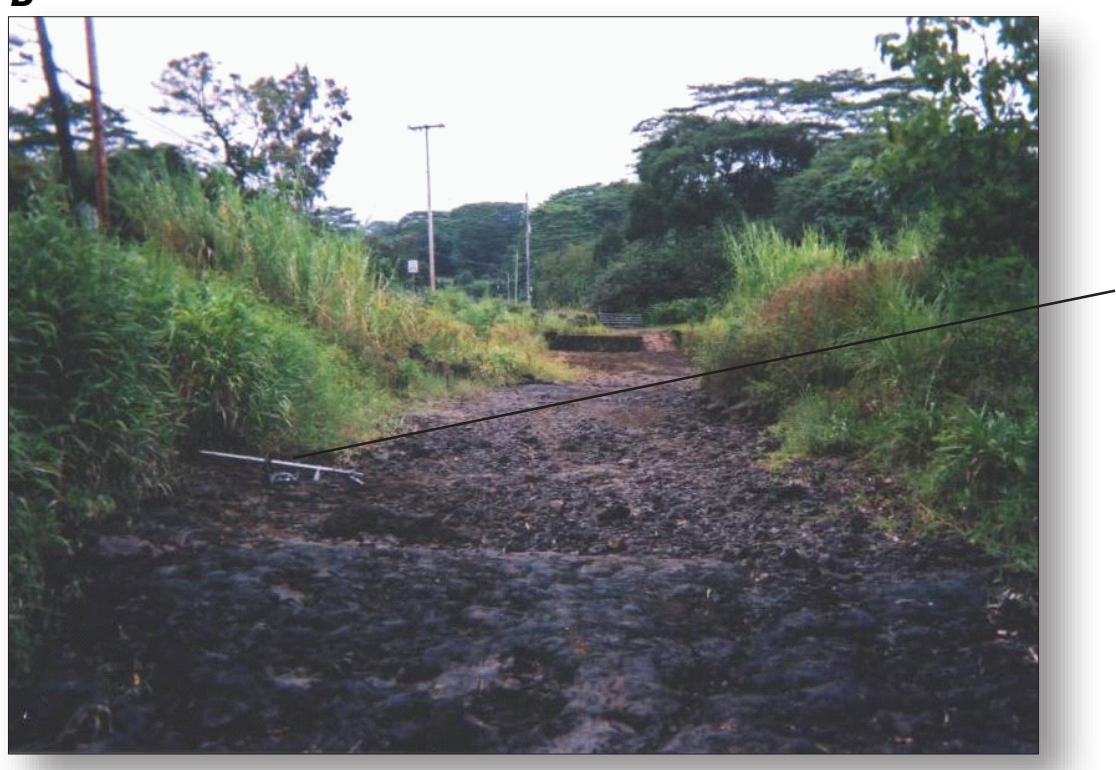

Pipe containing sampler tube and stream gage stage sensor

Figure 3. Photographs of sampling site and gage at Waiakea Stream at Hoaka Road (16700600), $(A)$ looking downstream and $(B)$ looking upstream, October 27, 2003, Hilo, Hawaii. 
$\boldsymbol{A}$

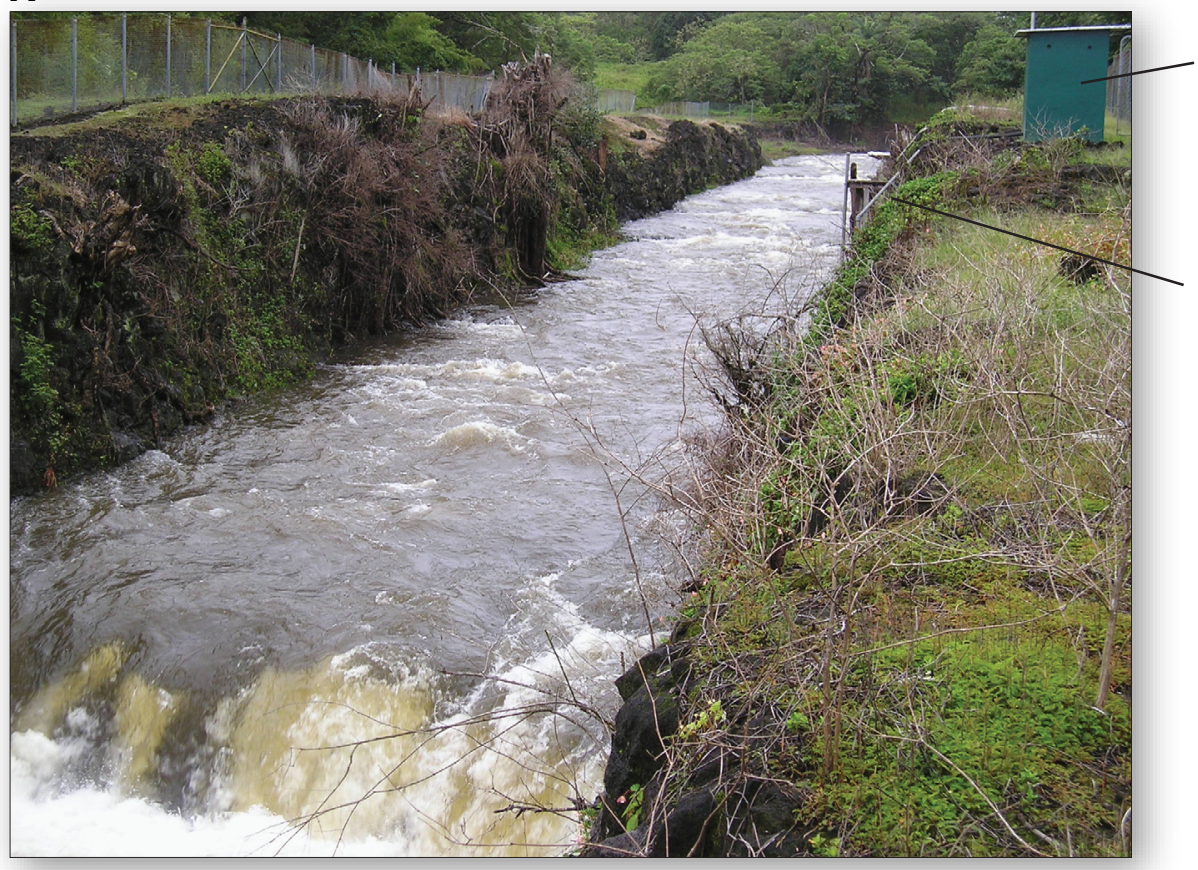

B

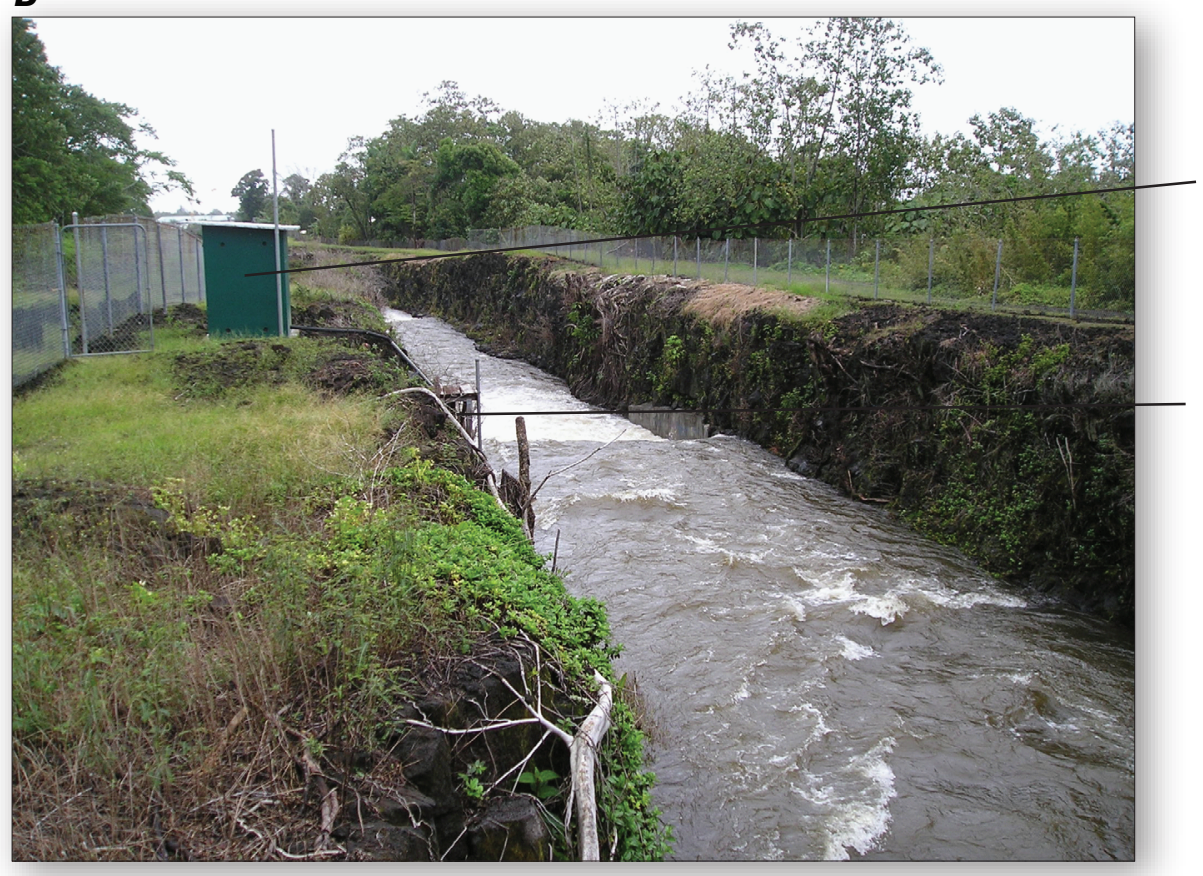

Gage house with autosampler

Pipe containing sampler tube and stream gage stage sensor

Gage house with autosampler

Pipe containing sampler tube and stream gage stage sensor

Figure 4. Photographs of sampling site and gage Waiakea Stream at Hilo (16701300), $(A)$ looking upstream, and $(B)$ looking downstream, on March 9, 2006, Hilo, Hawaii. 


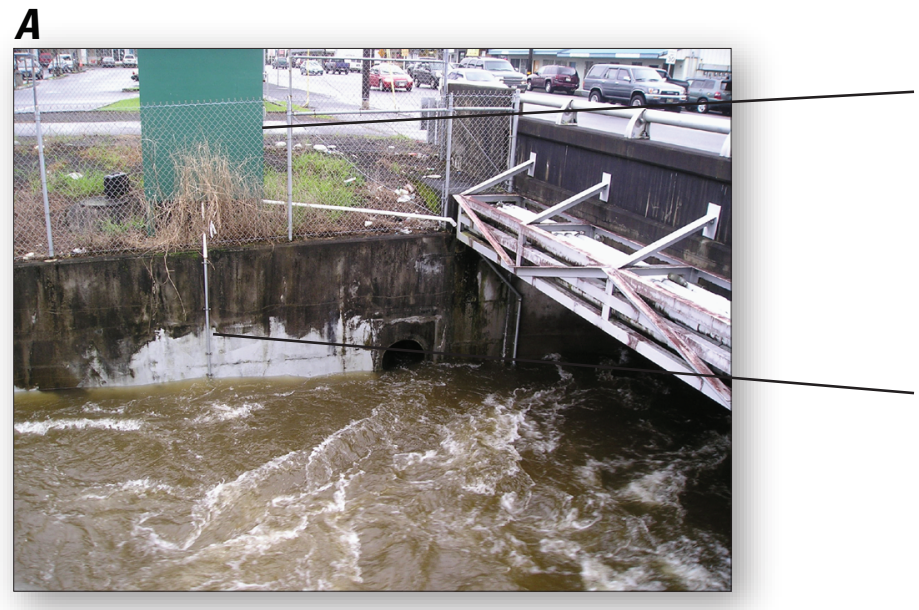

\author{
Gage house with \\ autosampler
}

Pipe containing sampler tube and stream gage stage sensor

\title{
$\boldsymbol{B}$
}

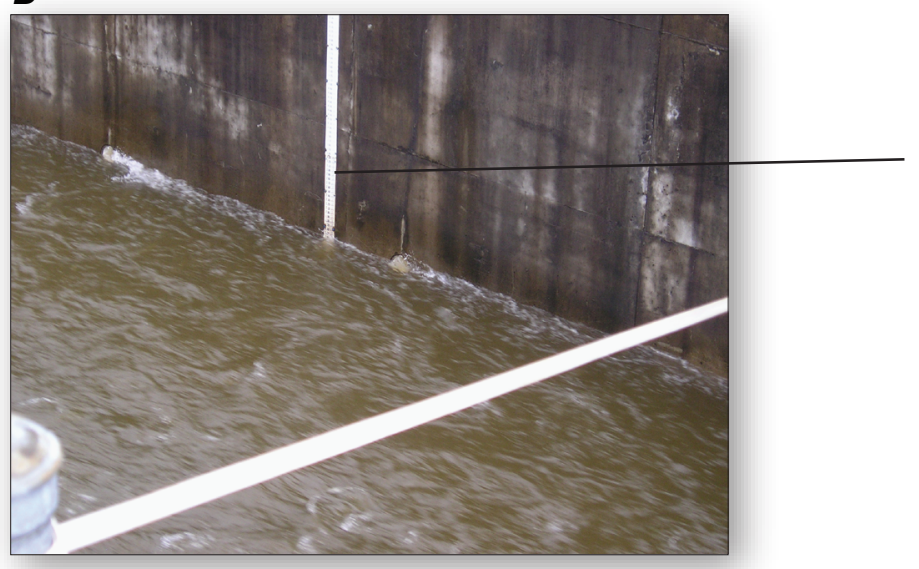

\section{Staff plate}

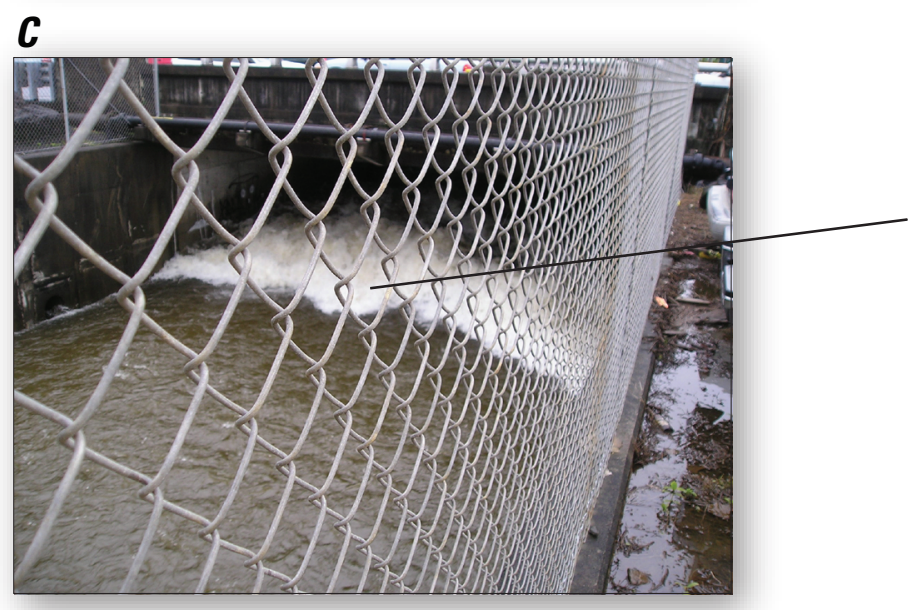

\section{Standing wave}

Figure 5. Photographs of sampling site and gage Alenaio Stream at Kilauea Avenue Bridge (16701650), $(A)$ gage house and sampling line, $(B)$ staff plate and $(C)$ standing wave downstream of gage, on March 9 , 2006, Hilo, Hawaii. 
$\boldsymbol{A}$

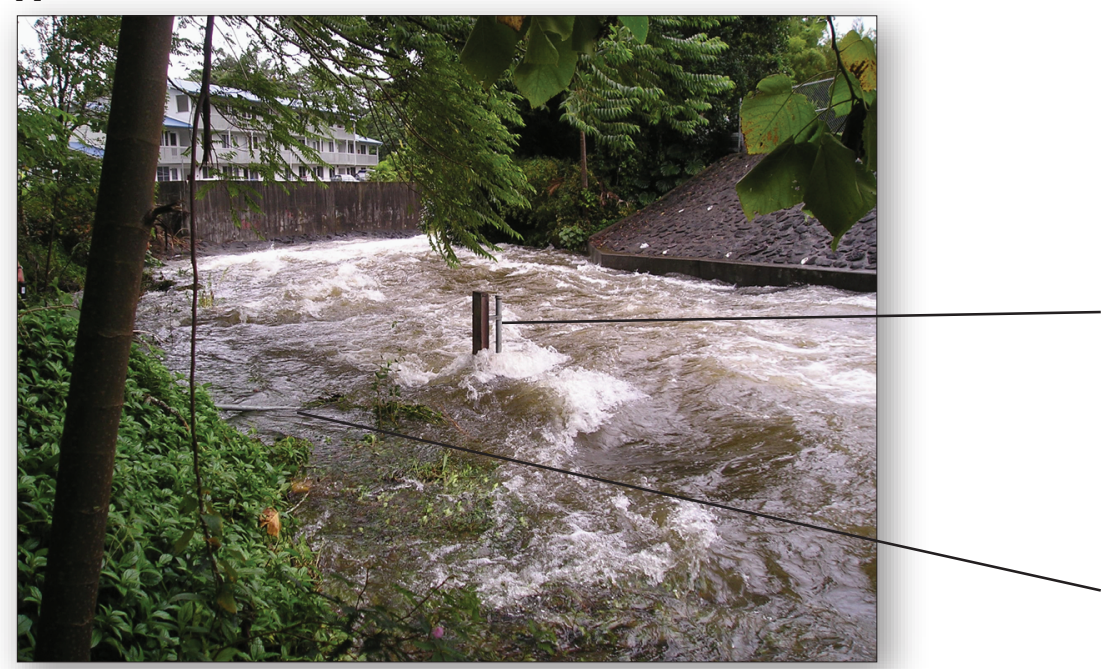

Crest gage and staff plate

Stream gage stage sensor pipe

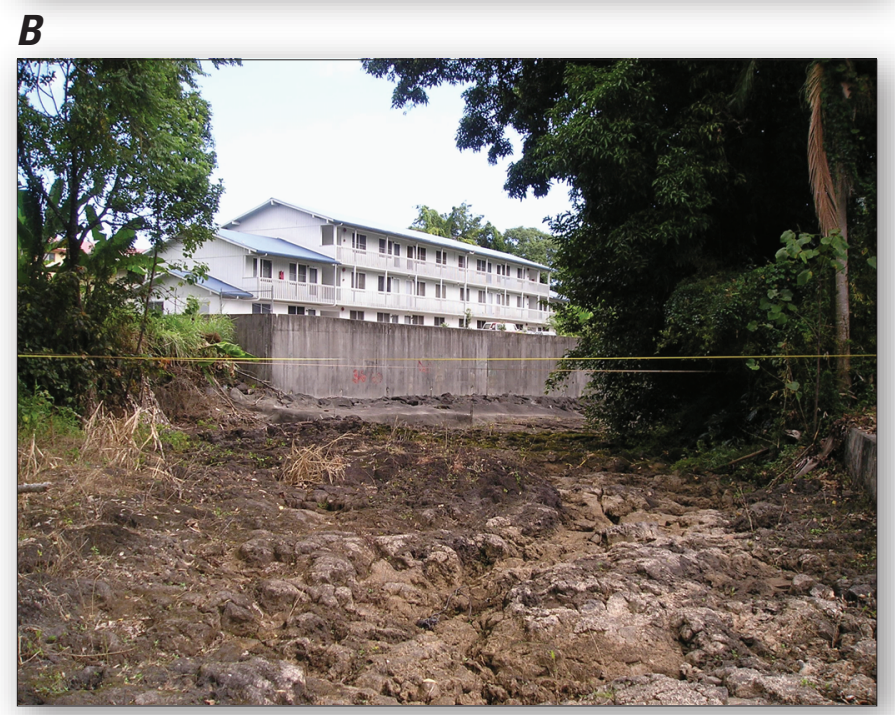

C

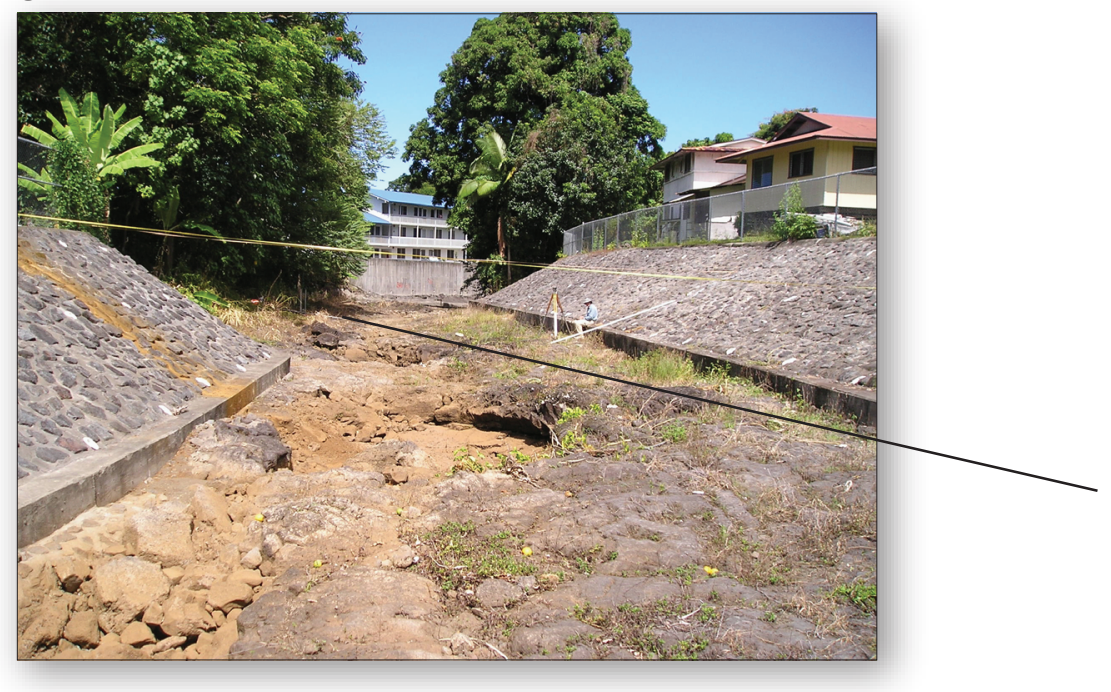

Stream gage stage sensor at end of pipe

Figure 6. Photographs of sampling site and gage at Alenaio Stream at Hilo (16701600), $(A)$ looking downstream during flow on March 9, 2006, $(B)$ looking downstream from gage during dry conditions on October 13, 2006, and $(C)$ looking downstream from upstream location, Hilo, Hawaii. 
Table 2. Descriptions of stream channels for Waiakea and Alenaio Streams, based on distance and altitude, Hilo, Hawaii. [Altitudes and Distances were estimated using a topographical map]

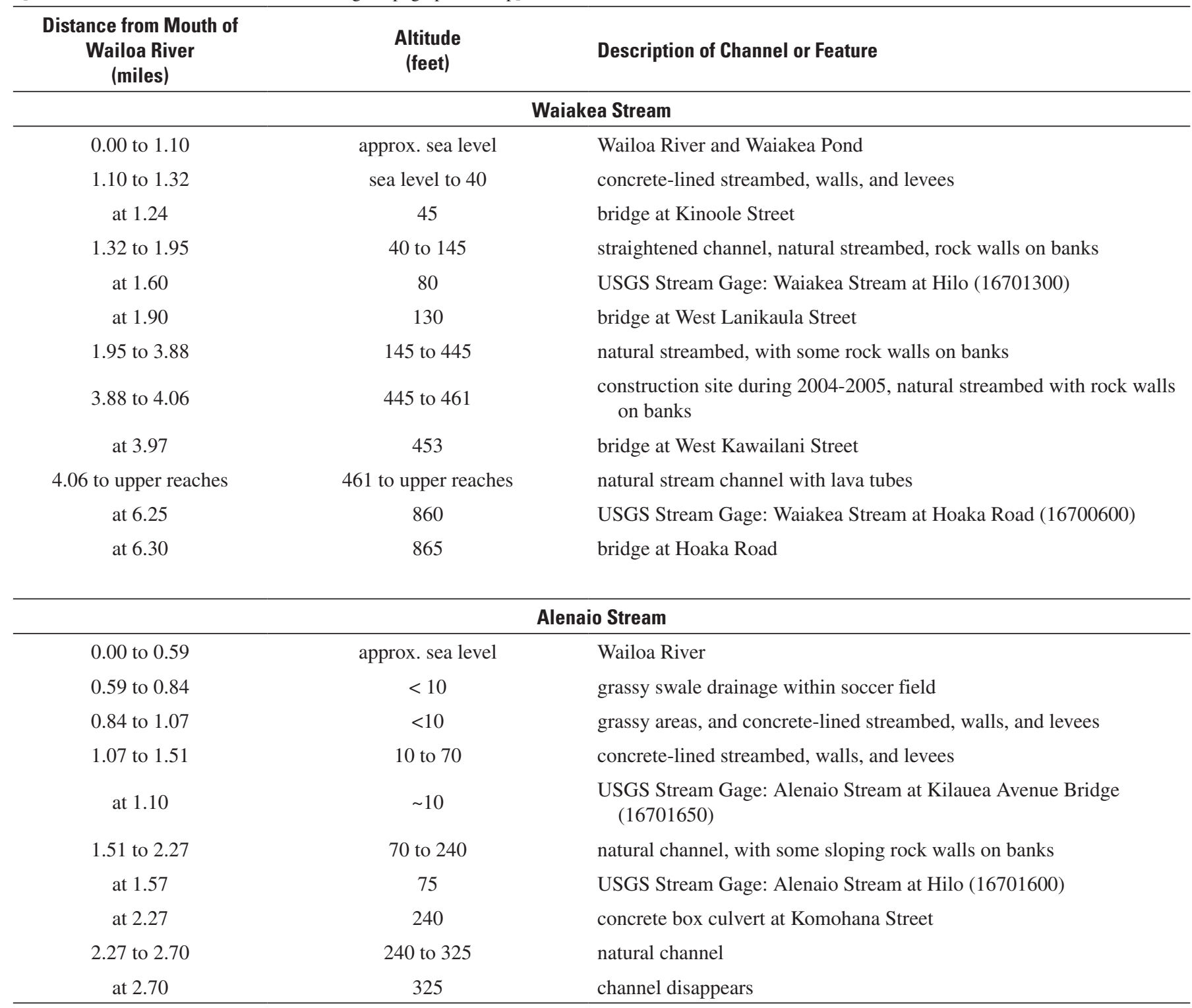

(fig. 4), and is about $0.50 \mathrm{mi}$ upstream from Waiakea Pond. Between 3.88 and 4.06 mi upstream of the mouth, at an altitude of about 445 to $461 \mathrm{ft}$, a flood-control channel (fig. 7) was constructed near the Kawailani Street Bridge beginning September 27, 2004, and ending June 1, 2005 (David Penn, HDOH, oral commun., 2006). This length of modified channel was a potential source of sediment load during the study.

Above the new flood control channel, the stream channel is natural with visible lava tubes. Waiakea Stream looses water along this reach between the new flood control channel and the Waiakea Stream at Hoaka Road sampling site.

Alenaio Stream. - Alenaio Stream flows into the upper part of the Waialama Canal, which is a grass-lined ditch. Above the grassy area for about $0.75 \mathrm{mi}$, the stream is a con- crete channel (fig. 5). Above the concrete lined channel, the stream channel bottom is natural with some sloping rock walls and concrete (fig. 6). The channel is natural beyond a concrete box covert at about $2.27 \mathrm{mi}$ upstream from the mouth. Alenaio Stream disappears in an upstream direction at about $2.7 \mathrm{mi}$ from the mouth, at an altitude of about $325 \mathrm{ft}$. Above this altitude, a channel is not distinguishable.

The drainage area for Alenaio Stream includes the drainages of Waipahoehoe Stream and Kaluiiki Branch (fig. 1 and 2). At lower flow rates, Waipahoehoe Stream looses all of its water due to percolation into lava flows, tubes and other volcanic features starting at about $700 \mathrm{ft}$ near Chong Street. Below Chong Street, the stream channel becomes undefined into a broader flood plain (U.S. Department of Agriculture, 
Soil Conservation Service, 1976), which eventually connects with the upper reaches of Alenaio Stream. Part of the stream flow from Waipahoehoe Stream likely reemerges into Alenaio Stream. At higher flows, a part of the total streamflow flows overland from Waipahoehoe Stream into Alenaio Stream. Due to the subsurface flow, however, water falling in this drainage may not discharge into Alenaio Stream; there is some evidence that water may flow into adjacent drainages through lava tubes and other volcanic features (Richard Fontaine, USGS Surface Water Specialist, oral commun., 2007).

It is important to note that while the Alenaio Stream at Kilauea Avenue Bridge site collects water at a location right at the point prior to the stream reaching the Wailama Canal and Wailoa River, the lower site on Waiakea Stream is about 0.50 mi upstream from Waiakea Pond. On the basis of the sampled water being representative of the water that reaches the estuarine environment of the Wailama Canal, Waiakea Pond, and Wailoa River area, the site Waiakea Stream at Hilo may miss a small portion of runoff from the urban area between Waiakea Pond and the site. In addition, since there is substantial water loss within the natural channels, large volumes of water must reach the estuarine area via subsurface flow.

\section{Soil Types Within the Drainage Areas of the Sites}

The areas, percentages, and hydrologic characteristics of soil types, as delineated in the Soil Survey of Hawaii County, Hawaii (Soil Survey Staff, 2006), were determined for the drainage areas of each site of this study. Within the drainage areas, 24 soil types out of the 150 soil types mapped on the island of Hawaii are found. Table 3 lists the soils found within



Figure 7. Photograph of Waiakea Stream flood control work near West Kawailani Street, January 11, 2005, Hilo, Hawaii. the drainage areas of the sites in this study, the area of each soil type and percentage within the drainage areas. The soils were grouped on the map (fig. 8) and in the table by their Soil Hydrologic Group (SHG) and Soil Erodibility Factor (K).

Soils in each Soil Hydrologic Group have similar runoff potential under similar storm and cover conditions. Soils are assigned to one of four groups according to the rate of water infiltration when the soils are not protected by vegetation, are thoroughly wet, and receive precipitation from long-duration storms. Although SHG A, B, C, and D are found within the drainage area for the site Waiakea Stream at Hilo, only SHG $\mathrm{C}$ and $\mathrm{D}$ (slow to very slow infiltration rates) are mapped within the drainage area for the site Alenaio Stream at Kilauea Avenue Bridge. SHG C and D (higher runoff potential) also make up 64 percent of the draingage area for Waiakea Stream at Hilo, while SHG A and B (high to moderate infiltration rates with lower runoff potential) make up the remaining 36 percent.

The Soil Erodibility Factor (K) indicates the susceptibility of a soil to sheet and rill erosion by water. It is one of six factors used in the Universal Soil Loss Equation (USLE) and the Revised Universal Soil Loss Equation (RUSLE) to predict the average annual rate of soil loss by sheet and rill erosion in tons per acre per year. Soil Erodibility Factors are further defined as Kf (rock free) and Kw (whole soil). Kf indicates the erodibility of the fine-earth fraction, or the material less than 2 millimeters. Kw indicates the erodibility of the whole soil such that the estimates are modified by the presence of rock fragments. For Hilo soils, $\mathrm{Kf}$ and $\mathrm{Kw}$ are the same for each soil map unit, except for the Puukala extremely stony silt loam, Puukala very rocky silt loam, and the Rock land soil types. $\mathrm{Kw}$ was used for these soil types due to their rocky or stony characteristics.

Other factors being equal, the higher the $\mathrm{K}$ value, the more susceptible the soil is to sheet and rill erosion by water. Global values for $\mathrm{K}$ range from 0.02 to 0.69 , while those for the 24 soil types within the drainage areas of this study range from 0.02 to 0.05 in all of the Alenaio drainage area and in 90.4 percent of the drainage area for Waiakea Stream at Hilo. Higher K value soils ( 0.10 to 0.20$)$ are mapped in 9.6 percent of the drainage area for Waiakea Stream at Hilo; occurring at the upper elevations. Most of the area of soils of higher K value are associated with the high runoff potential SHG D.

\section{Land Cover Within the Drainage Areas of the Sites}

The National Oceanographic and Atmospheric Administration (NOAA) Coastal Change Analysis Program (C-CAP) map of land covers (National Oceanographic and Atmospheric Administration, 2001), was used to define the land-cover percentages in the drainage areas. Of the 22 land cover classes mapped nationwide by the NOAA Coastal Change Analysis Program, twelve classes are found on the island of Hawaii, 
Table 3. Areas and percentages of soil map units within drainage areas of sites used in study, Hilo Hawaii.

[Hydrologic Group, groups defined by the National Resource Conservation Service based on the soil's runoff potential; Soil Map Unit Abbreviation, as defined by the National Resource Conservation Service; $\mathrm{K}$, soil erodibility factor is a measure of the soil's susceptiblity to water erosion]

\begin{tabular}{|c|c|c|c|c|c|c|c|c|c|c|c|c|}
\hline \multirow[b]{2}{*}{ Soil Map Unit* } & \multirow{2}{*}{$\begin{array}{l}\text { Soil Map } \\
\text { Unit Percent } \\
\text { Slopes }\end{array}$} & \multirow{2}{*}{$\begin{array}{c}\text { Soil Map } \\
\text { Unit } \\
\text { Abbreviation } \\
\text { Symbol }\end{array}$} & \multirow[b]{2}{*}{$\begin{array}{l}\text { Soil Type } \\
\text { Symbol }\end{array}$} & \multirow{2}{*}{$\begin{array}{c}\text { Soil } \\
\text { Erodibility } \\
\text { Factor } \\
\text { K } \\
\text { Symbol }\end{array}$} & \multicolumn{2}{|c|}{$\begin{array}{l}\text { Waiakea Stream at Hoaka Road } \\
(16700600)\end{array}$} & \multicolumn{2}{|c|}{$\begin{array}{c}\text { Waiakea Stream at Hilo } \\
(16701300)\end{array}$} & \multicolumn{2}{|c|}{ Alenaio Stream at Hilo (16701600) } & \multicolumn{2}{|c|}{$\begin{array}{c}\text { Alenaio Stream at } \\
\text { Kilauea Avenue } \\
\text { Bridge (16701650) } \\
\end{array}$} \\
\hline & & & & & acres & $\begin{array}{c}\text { percent of } \\
\text { drainage } \\
\text { area }\end{array}$ & acres & $\begin{array}{c}\text { percent } \\
\text { of } \\
\text { drainage } \\
\text { area }\end{array}$ & acres & $\begin{array}{c}\text { percent of } \\
\text { drainage area }\end{array}$ & acres & $\begin{array}{c}\text { percent } \\
\text { of } \\
\text { drainage } \\
\text { area }\end{array}$ \\
\hline \multicolumn{13}{|c|}{ Hydrologic Group A } \\
\hline Lava flows, aa & -- & rLV & -- & 0.02 & $2,407.1$ & 11.8 & $2,407.1$ & 10.5 & 0.0 & 0.0 & 0.0 & 0.0 \\
\hline $\begin{array}{l}\text { Mawae ex- } \\
\text { tremely stony } \\
\text { muck }\end{array}$ & 6 to 20 & rMWD & Histosol & 0.02 & 650.2 & 3.2 & 650.2 & 2.8 & 0.0 & 0.0 & 0.0 & 0.0 \\
\hline $\begin{array}{l}\text { Kiloa extremely } \\
\text { stony muck }\end{array}$ & 6 to 20 & $\mathrm{rKXD}$ & Histosol & 0.05 & $3,644.6$ & 17.9 & $3,644.6$ & 15.9 & 0.0 & 0.0 & 0.0 & 0.0 \\
\hline $\begin{array}{l}\text { Papai extremely } \\
\text { stony muck }\end{array}$ & 3 to 25 & rPAE & Histosol & 0.05 & 0.0 & 0.0 & 10.0 & 0.0 & 0.0 & 0.0 & 0.0 & 0.0 \\
\hline $\begin{array}{l}\text { Total Area of } \\
\text { Hydrologic } \\
\text { Group A }\end{array}$ & & & & & $6,701.9$ & 33.0 & $6,711.9$ & 29.3 & 0.0 & 0.0 & 0.0 & 0.0 \\
\hline \multicolumn{13}{|c|}{ Hydrologic Group B } \\
\hline $\begin{array}{l}\text { Ohia silty clay } \\
\text { loam }\end{array}$ & 0 to 10 & $\mathrm{OHC}$ & Andisol & 0.05 & 329.1 & 1.6 & 450.8 & 2.0 & 0.0 & 0.0 & 0.0 & 0.0 \\
\hline $\begin{array}{l}\text { Olaa silty clay } \\
\text { loam }\end{array}$ & 0 to 10 & $\mathrm{OaC}$ & Andisol & 0.05 & 3.6 & 0.0 & 227.5 & 1.0 & 0.0 & 0.0 & 0.0 & 0.0 \\
\hline $\begin{array}{l}\text { Olaa extremely } \\
\text { stony silty } \\
\text { clay loam }\end{array}$ & 0 to 20 & OID & Andisol & 0.05 & 129.7 & 0.6 & 863.9 & 3.8 & 0.0 & 0.0 & 0.0 & 0.0 \\
\hline $\begin{array}{l}\text { Ohia extremely } \\
\text { stony silty } \\
\text { clay loam }\end{array}$ & 0 to 20 & OSD & Andisol & 0.05 & 118.2 & 0.6 & 124.5 & 0.5 & 0.0 & 0.0 & 0.0 & 0.0 \\
\hline $\begin{array}{l}\text { Total Area in } \\
\text { Hydrologic } \\
\text { Group B }\end{array}$ & & & & & 580.6 & 2.9 & $1,666.7$ & 7.3 & 0.0 & 0.0 & 0.0 & 0.0 \\
\hline
\end{tabular}


Table 3. Areas and percentages of soil map units within drainage areas of sites used in study, Hilo Hawaii.-Continued.

[Hydrologic Group, groups defined by the National Resource Conservation Service based on the soil's runoff potential; Soil Map Unit Abbreviation, as defined by the National Resource Conservation Service; $\mathrm{K}$, soil erodibility factor is a measure of the soil's susceptiblity to water erosion]

\begin{tabular}{|c|c|c|c|c|c|c|c|c|c|c|c|c|}
\hline \multirow[b]{2}{*}{ Soil Map Unit* } & \multirow{2}{*}{$\begin{array}{l}\text { Soil Map } \\
\text { Unit Percent } \\
\text { Slopes }\end{array}$} & \multirow{2}{*}{$\begin{array}{c}\text { Soil Map } \\
\text { Unit } \\
\text { Abbreviation } \\
\text { Symbol }\end{array}$} & \multirow{2}{*}{$\begin{array}{l}\text { Soil Type } \\
\text { Symbol }\end{array}$} & \multirow{2}{*}{$\begin{array}{c}\text { Soil } \\
\text { Erodibility } \\
\text { Factor } \\
\text { K } \\
\text { Symbol }\end{array}$} & \multicolumn{2}{|c|}{$\begin{array}{c}\text { Waiakea Stream at Hoaka Road } \\
(16700600)\end{array}$} & \multicolumn{2}{|c|}{$\begin{array}{c}\text { Waiakea Stream at Hilo } \\
(\mathbf{1 6 7 0 1 3 0 0 )}\end{array}$} & \multicolumn{2}{|c|}{ Alenaio Stream at Hilo (16701600) } & \multicolumn{2}{|c|}{$\begin{array}{c}\text { Alenaio Stream at } \\
\text { Kilauea Avenue } \\
\text { Bridge (16701650) } \\
\end{array}$} \\
\hline & & & & & acres & $\begin{array}{l}\text { percent of } \\
\text { drainage } \\
\text { area }\end{array}$ & acres & $\begin{array}{c}\text { percent } \\
\text { of } \\
\text { drainage } \\
\text { area }\end{array}$ & acres & $\begin{array}{c}\text { percent of } \\
\text { drainage area }\end{array}$ & acres & $\begin{array}{c}\text { percent } \\
\text { of } \\
\text { drainage } \\
\text { area } \\
\end{array}$ \\
\hline \multicolumn{13}{|c|}{ Hydrologic Group C } \\
\hline $\begin{array}{l}\text { Lava flows, } \\
\text { pahoehoe }\end{array}$ & -- & $\mathrm{rLW}$ & -- & 0.02 & 79.4 & 0.4 & 852.4 & 3.7 & $1,491.7$ & 27.5 & $1,491.7$ & 26.7 \\
\hline $\begin{array}{l}\text { Akaka silty clay } \\
\text { loam }\end{array}$ & 10 to 20 & $\mathrm{AkD}$ & Andisol & 0.05 & $2,241.3$ & 11.0 & $2,241.3$ & 9.8 & 0.0 & 0.0 & 0.0 & 0.0 \\
\hline $\begin{array}{l}\text { Hilo silty clay } \\
\text { loam }\end{array}$ & 0 to 10 & $\mathrm{HoC}$ & Andisol & 0.05 & 0.0 & 0.0 & 0.0 & 0.0 & 127.9 & 2.4 & 251.9 & 4.5 \\
\hline $\begin{array}{l}\text { Hilo silty clay } \\
\text { loam }\end{array}$ & 10 to 20 & HoD & Andisol & 0.05 & 0.0 & 0.0 & 0.0 & 0.0 & 14.4 & 0.3 & 14.4 & 0.3 \\
\hline $\begin{array}{l}\text { Kaiwiki silty } \\
\text { clay loam }\end{array}$ & 0 to 10 & $\mathrm{KaC}$ & Andisol & 0.05 & 0.0 & 0.0 & 0.0 & 0.0 & 397.0 & 7.3 & 397.0 & 7.1 \\
\hline $\begin{array}{l}\text { Kaiwiki silty } \\
\text { clay loam }\end{array}$ & 10 to 20 & $\mathrm{KaD}$ & Andisol & 0.05 & 0.0 & 0.0 & 0.0 & 0.0 & 183.2 & 3.4 & 183.2 & 3.3 \\
\hline $\begin{array}{l}\text { Kaiwiki silty } \\
\text { clay loam }\end{array}$ & 20 to 35 & $\mathrm{KaE}$ & Andisol & 0.05 & 0.0 & 0.0 & 0.0 & 0.0 & 0.3 & 0.0 & 0.3 & 0.0 \\
\hline Very stony land & -- & rVS & -- & 0.20 & 86.1 & 0.4 & 86.1 & 0.4 & 0.0 & 0.0 & 0.0 & 0.0 \\
\hline $\begin{array}{l}\text { Total Area in } \\
\text { Hydrologic } \\
\text { Group C }\end{array}$ & & & & & $2,406.8$ & 11.8 & $3,179.8$ & 13.9 & $2,214.6$ & 40.8 & $2,338.5$ & 41.8 \\
\hline
\end{tabular}


Table 3. Areas and percentages of soil map units within drainage areas of sites used in study, Hilo Hawaii.-Continued.

[Hydrologic Group, groups defined by the National Resource Conservation Service based on the soil's runoff potential; Soil Map Unit Abbreviation, as defined by the National Resource Conservation Service; $\mathrm{K}$, soil erodibility factor is a measure of the soil's susceptiblity to water erosion]

\begin{tabular}{|c|c|c|c|c|c|c|c|c|c|c|c|c|}
\hline \multirow[b]{2}{*}{ Soil Map Unit* } & \multirow{2}{*}{$\begin{array}{l}\text { Soil Map } \\
\text { Unit Percent } \\
\text { Slopes }\end{array}$} & \multirow{2}{*}{$\begin{array}{c}\text { Soil Map } \\
\text { Unit } \\
\text { Abbreviation } \\
\text { Symbol }\end{array}$} & \multirow{2}{*}{$\begin{array}{l}\text { Soil Type } \\
\text { Symbol }\end{array}$} & \multirow{2}{*}{$\begin{array}{c}\text { Soil } \\
\text { Erodibility } \\
\text { Factor } \\
\text { K } \\
\text { Symbol }\end{array}$} & \multicolumn{2}{|c|}{$\begin{array}{l}\text { Waiakea Stream at Hoaka Road } \\
(16700600)\end{array}$} & \multicolumn{2}{|c|}{$\begin{array}{l}\text { Waiakea Stream at Hilo } \\
(16701300)\end{array}$} & \multicolumn{2}{|c|}{ Alenaio Stream at Hilo (16701600) } & \multicolumn{2}{|c|}{$\begin{array}{c}\text { Alenaio Stream at } \\
\text { Kilauea Avenue } \\
\text { Bridge (16701650) }\end{array}$} \\
\hline & & & & & acres & $\begin{array}{c}\text { percent of } \\
\text { drainage } \\
\text { area }\end{array}$ & acres & $\begin{array}{c}\text { percent } \\
\text { of } \\
\text { drainage } \\
\text { area } \\
\end{array}$ & acres & $\begin{array}{c}\text { percent of } \\
\text { drainage area }\end{array}$ & acres & $\begin{array}{c}\begin{array}{c}\text { percent } \\
\text { of } \\
\text { drainage } \\
\text { area }\end{array} \\
\end{array}$ \\
\hline \multicolumn{13}{|c|}{ Hydrologic Group D } \\
\hline $\begin{array}{c}\text { Panaewa very } \\
\text { rocky silty } \\
\text { clay loam }\end{array}$ & 0 to 10 & $\mathrm{PeC}$ & Andisol & 0.05 & 33.3 & 0.2 & 187.6 & 0.8 & 0.0 & 0.0 & 0.0 & 0.0 \\
\hline $\begin{array}{l}\text { Kahaluu } \\
\text { extremely } \\
\text { rocky muck }\end{array}$ & 6 to 20 & rKAD & Histosol & 0.05 & $4,971.8$ & 24.5 & $4,971.8$ & 21.7 & 0.0 & 0.0 & 0.0 & 0.0 \\
\hline $\begin{array}{l}\text { Keaukaha } \\
\text { extremely } \\
\text { rocky muck }\end{array}$ & 6 to 20 & rKFD & Histosol & 0.05 & 5.7 & 0.0 & 401.3 & 1.8 & $1,271.2$ & 23.4 & $1,318.5$ & 23.6 \\
\hline $\begin{array}{l}\text { Keei extreme- } \\
\text { ly rocky } \\
\text { muck }\end{array}$ & 6 to 20 & rKGD & Histosol & 0.05 & $3,645.8$ & 17.9 & $3,809.0$ & 16.6 & $1,938.6$ & 35.7 & $1,938.6$ & 34.6 \\
\hline $\begin{array}{l}\text { Hilea silty } \\
\text { clay loam }\end{array}$ & 6 to 12 & $\mathrm{HlC}$ & Andisol & 0.05 & 99.2 & 0.5 & 99.2 & 0.4 & 0.0 & 0.0 & 0.0 & 0.0 \\
\hline $\begin{array}{l}\text { Puukala } \\
\text { extremely } \\
\text { stony silt } \\
\text { loam** }\end{array}$ & 6 to 12 & PSC & Andisol & 0.10 & 190.9 & 0.9 & 190.9 & 0.8 & 0.0 & 0.0 & 0.0 & 0.0 \\
\hline $\begin{array}{c}\text { Puukala very } \\
\text { rocky silt } \\
\text { loam** }\end{array}$ & 6 to 12 & PTC & Andisol & 0.10 & 246.9 & 1.2 & 246.9 & 1.1 & 0.0 & 0.0 & 0.0 & 0.0 \\
\hline Rock land** & -- & rRO & -- & 0.20 & $1,434.7$ & 7.1 & $1,434.7$ & 6.3 & 0.0 & 0.0 & 0.0 & 0.0 \\
\hline $\begin{array}{l}\text { Total Area in } \\
\text { Hydrologic } \\
\text { Group D }\end{array}$ & & & & & $10,628.2$ & 52.3 & $11,341.4$ & 49.5 & $3,209.7$ & 59.2 & $3,257.1$ & 58.2 \\
\hline
\end{tabular}


Table 3. Areas and percentages of soil map units within drainage areas of sites used in study, Hilo Hawaii.-Continued.

[Hydrologic Group, groups defined by the National Resource Conservation Service based on the soil's runoff potential; Soil Map Unit Abbreviation, as defined by the National Resource Conservation Service; $\mathrm{K}$, soil erodibility factor is a measure of the soil's susceptiblity to water erosion]

\begin{tabular}{|c|c|c|c|c|c|c|c|c|c|c|c|c|}
\hline \multirow[b]{2}{*}{ Soil Map Unit* } & \multirow{2}{*}{$\begin{array}{l}\text { Soil Map } \\
\text { Unit Percent } \\
\text { Slopes }\end{array}$} & \multirow{2}{*}{$\begin{array}{c}\text { Soil Map } \\
\text { Unit } \\
\text { Abbreviation } \\
\text { Symbol }\end{array}$} & \multirow{2}{*}{$\begin{array}{l}\text { Soil Type } \\
\text { Symbol }\end{array}$} & \multirow{2}{*}{$\begin{array}{c}\text { Soil } \\
\text { Erodibility } \\
\text { Factor } \\
\mathbf{K} \\
\text { Symbol }\end{array}$} & \multicolumn{2}{|c|}{$\begin{array}{c}\text { Waiakea Stream at Hoaka Road } \\
(16700600)\end{array}$} & \multicolumn{2}{|c|}{$\begin{array}{c}\text { Waiakea Stream at Hilo } \\
(16701300)\end{array}$} & \multicolumn{2}{|c|}{ Alenaio Stream at Hilo (16701600) } & \multicolumn{2}{|c|}{$\begin{array}{l}\text { Alenaio Stream at } \\
\text { Kilauea Avenue } \\
\text { Bridge (16701650) }\end{array}$} \\
\hline & & & & & acres & $\begin{array}{l}\text { percent of } \\
\text { drainage } \\
\text { area }\end{array}$ & acres & $\begin{array}{c}\text { percent } \\
\text { of } \\
\text { drainage } \\
\text { area }\end{array}$ & acres & $\begin{array}{c}\text { percent of } \\
\text { drainage area }\end{array}$ & acres & $\begin{array}{c}\begin{array}{c}\text { percent } \\
\text { of } \\
\text { drainage } \\
\text { area }\end{array} \\
\end{array}$ \\
\hline \multicolumn{13}{|c|}{ Totals by Soil Type or Erosivity Factor } \\
\hline Andisols & & & & & $3,392.2$ & 16.7 & $4,632.6$ & 20.2 & 722.8 & 13.3 & 846.8 & 15.1 \\
\hline Histosols & & & & & $12,918.0$ & 63.6 & $13,486.9$ & 58.9 & $3,209.7$ & 59.2 & $3,257.1$ & 58.2 \\
\hline $\begin{array}{l}\text { Lava flows, } \\
\text { stony land, } \\
\text { and rock } \\
\text { land }\end{array}$ & & & & & $4,007.4$ & 19.7 & $4,780.4$ & 20.9 & $1,491.7$ & 27.5 & $1,491.7$ & 26.7 \\
\hline Soil Erosivity & & & & & & & & & & & & \\
\hline $\begin{array}{l}\text { Index K = } \\
0.02\end{array}$ & & & & & $3,136.7$ & 15.4 & $3,909.7$ & 17.1 & $1,491.7$ & 27.5 & $1,491.7$ & 26.7 \\
\hline Soil Erosivity & & & & & & & & & & & & \\
\hline $\begin{array}{l}\text { Index } \mathrm{K}= \\
0.05\end{array}$ & & & & & $15,222.2$ & 74.9 & $17,031.5$ & 74.4 & $3,932.6$ & 72.5 & $4,103.9$ & 73.3 \\
\hline Soil Erosivity & & & & & & & & & & & & \\
\hline $\begin{array}{l}\text { Index } \mathrm{K}= \\
0.10\end{array}$ & & & & & 437.8 & 2.2 & 437.8 & 1.9 & 0.0 & 0.0 & 0.0 & 0.0 \\
\hline $\begin{array}{l}\text { Soil Erosivity } \\
\text { Index K = } \\
0.20\end{array}$ & & & & & $1,520.8$ & 7.5 & $1,520.8$ & 6.6 & 0.0 & 0.0 & 0.0 & 0.0 \\
\hline $\begin{array}{l}\text { Total Area in } \\
\text { Drainage }\end{array}$ & & & & & $20,317.5$ & & $22,899.8$ & & $5,424.3$ & & $5,595.6$ & \\
\hline
\end{tabular}

*Data from Hawaii; U.S. Department of Agriculture Natural Resources Conservation Service (Soil Survey Staff, 2006)

**Soil erosion factor $\mathrm{K}$ for these soil types is the soil erosion factor $\mathrm{Kw}$ (whole soil). All other soil types have equal Kf (rock free, material less than $2 \mathrm{~mm}$ ) and Kw. 


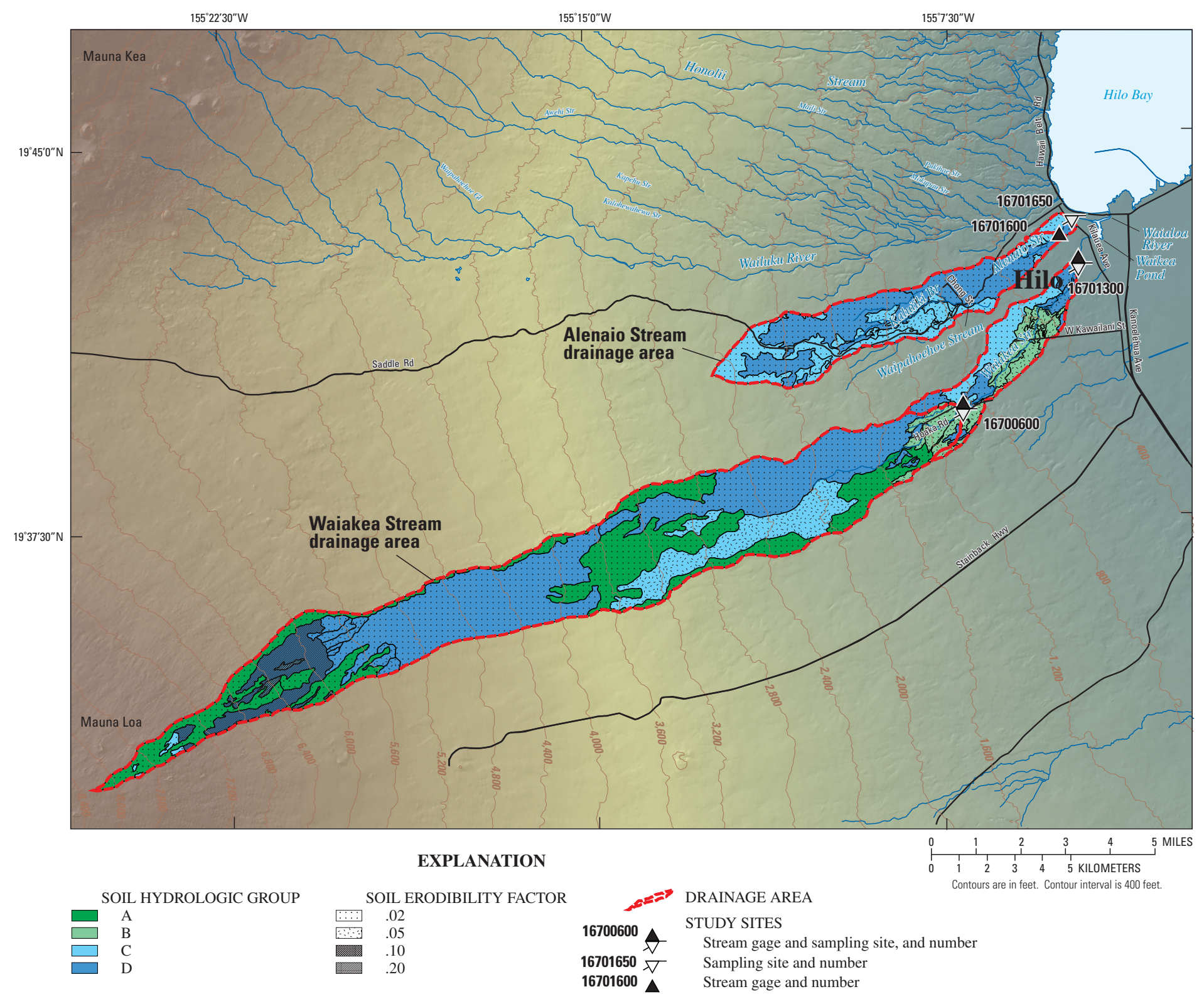

Figure 8. Map showing soil hydrologic groups and soil erodibility factors within drainage areas of stream-gaging and sampling sites for this study, Hilo, Hawaii. 
nine of these twelve are common to the combined drainage areas of the three sampling sites of this study (table 4, fig. 9).

The land-cover classes with the highest coverages within the study area are 'evergreen forest' and 'scrub/shrub', covering 72.8 and 12.7 percent, respectively, of the drainage area above the site Waiakea Stream at Hilo, and 42.5 and 24.7 percent, respectively, of the drainage area above Alenaio Stream at Kilauea Avenue Bridge. Both of the lower sites of Waiakea and Alenaio streams have less than 2 percent 'hiintensity developed', whereas only the lower site on Alenaio has appreciable 'low-intensity developed' land cover class at 11.3 percent. The remainder of the area of the drainages is comprised mostly of 'grassland', 'bare land', and 'cultivated land'. Definitions for these land-cover classes are available on-line (National Oceanographic and Atmospheric Administration, 2006).

\section{Study Methods}

Water quality samples for suspended sediment and nutrient analysis were collected at Waiakea Stream at Hoaka Road, Waiakea Stream at Hilo, and Alenaio Stream at Kilauea Avenue Bridge during wet weather storm events during March 2004 to March . Beginning and ending dates for data collection, the number of events, and the number of samples collected are listed in table 5. Sampling did not overlap between the two sites.

Methods used to collect the discharge and water quality data conformed to standard U.S. Geological Survey practices (Rantz and others, 1982; Wilde and others, 1998; Edwards and Glysson, 1999). The method used for developing daily-mean load for the constituents utilized U.S. Geological Survey software and techniques (McKallip and others, 2001).

\section{Discharge Measurements and Continuous Record}

Stream discharge was measured at the two sites on Waiakea Stream, and the two sites on Aleniao Stream. A continuous record of discharge was computed for the two sites on Waiakea Stream, and only the upper site of Alenaio Stream, Alenaio Stream at Hilo, using standard USGS methods (Rantz and others, 1982). These methods include a continuous record of stage measured every 15 minutes, individual measurements of discharge over a range of stages, development of a 'rating' to relate stage to discharge, and notations regarding factors that may affect the relations between stage and discharge.

During water years 2004 and 2005 (a 'water year' spans from October 1 to September 30, and takes the number of the calendar year in which it ends), instrument failure or malfunction caused short losses of record at both Waiakea Stream at Hoaka Road and Waiakea Stream at Hilo (table 5). The data gaps were estimated either visually or by regression methods using discharge records from long-term stations Honolii
Stream near Papaikou (station number 16717000, figs. 1 and 2) and Wailuku River at Piihonua (station number 16704000, figs. 1 and 2).

Because of a hydraulic effect within the concrete channel, it was not possible to determine an accurate stage / discharge relation for the site Alenaio Stream at Kilauea Avenue Bridge. Photographs of discharge during January 26, 2006, show a hydraulic jump in the form of a standing wave near the measuring device of the gage (fig. 5). At higher flows, the standing wave moved away from the gage. Only instantaneous discharge measurements were made at Alenaio Stream at Kilauea Avenue Bridge using surface velocity measurements and a cross-section area (determined from stage height and predetermined channel geometry) during sampling; wading measurements using standard flow meters would be too dangerous to conduct in the slippery concrete channel. A continuous record of stream flow was not computed. Not all of the samples collected at Alenaio Stream at Kilauea Avenue Bridge have associated discharge measurements.

In addition to the measurements made at Alenaio Stream at Kilauea Avenue Bridge, and in lieu of a continuous discharge record at this site, stage and discharge were measured upstream at Alenaio Stream at Hilo. A stage/discharge relation and a continuous record of discharge were determined for this site using available measurements and computer modeling methods.

Daily-mean discharge (fig. 10) was computed using unitvalue data (computed from the stage data measured every 15 minutes) for Waiakea Stream at Hoaka Road, Waiakea Stream at Hilo, and Alenaio Stream at Hilo. The duration of discharge record and the duration of data gaps for these sites are shown in table 5.

\section{Sample Collection and Strategy}

Flowing streamwater, in general, will have temporal and spatial heterogeneity. In order to adequately sample a stream, automated point samples are collected over time, either at specific intervals or based on discharge at irregular intervals. In order to represent the spatial heterogeneity, isokinetic, depthintegrating sampling methods are used to produce a discharge weighted sample for a discrete time (usually within 30 minutes or less); thus, each unit of stream discharge across the width and depth of the stream is equally represented in the sample (Wilde and others, 1998). By using the constituent concentration data from discharge weighted samples collected concurrently with automated point samples, a cross-section coefficient can be determined to adjust the automated point samples to better represent the constituent discharge for the stream spatially. In turn, the adjusted values from the automated point samples are used with discharge data to estimate the constituent concentrations and loads through time.

For this study, automated point samples were collected during storms, and whenever practical, discharge-weighted samples were collected concurrently with automated point 
Table 4. Areas and percentages of NOAA C-CAP land cover classes within drainage areas of sites used in study, Hilo Hawaii. [NOAA C-CAP Class Name, land cover classes defined by the NOAA Coastal Change Analysis program (National Oceanographic and Atmospheric Administration, 1995, 2001, and 2006); $\mathrm{mi}^{2}$, square miles]

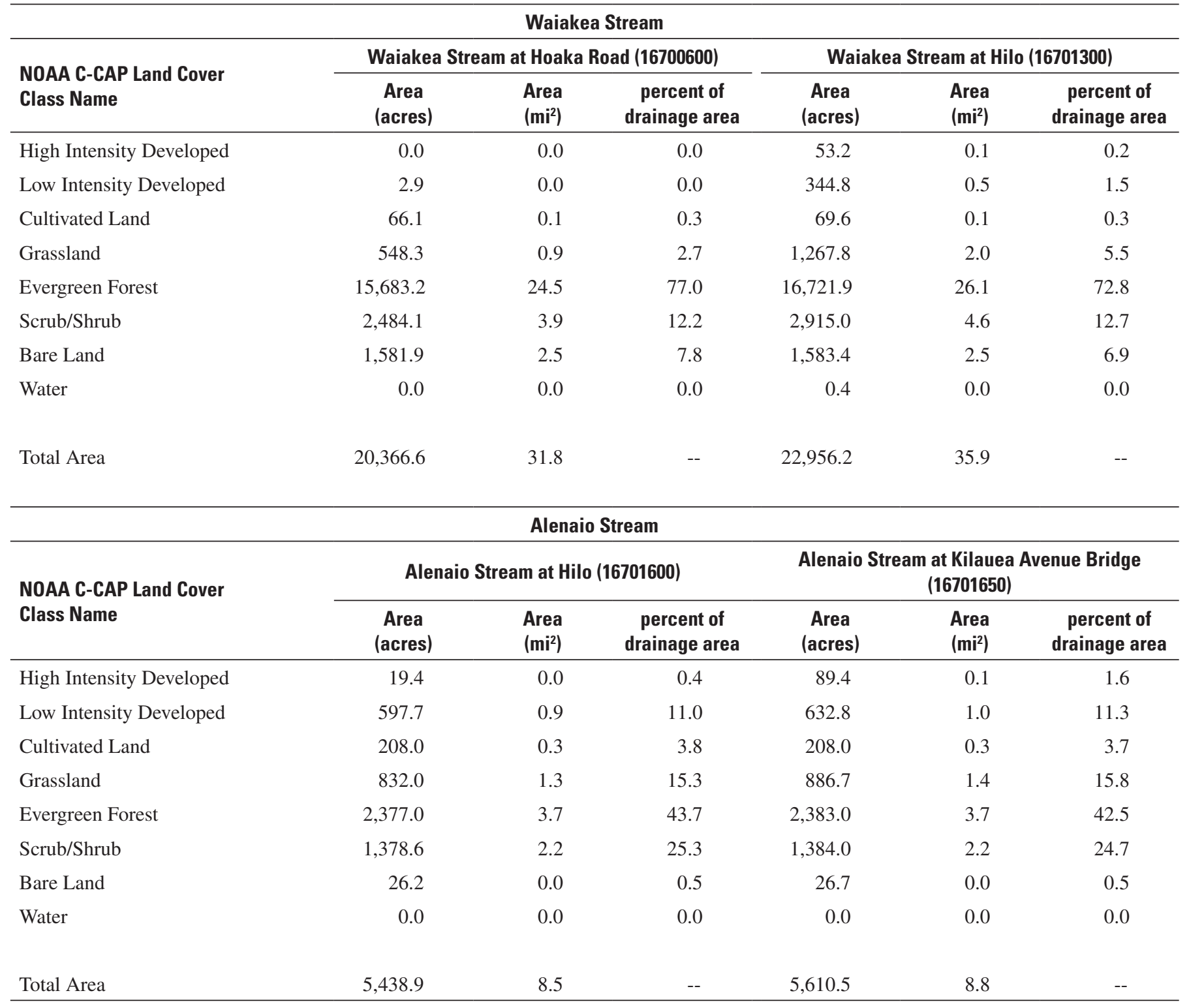




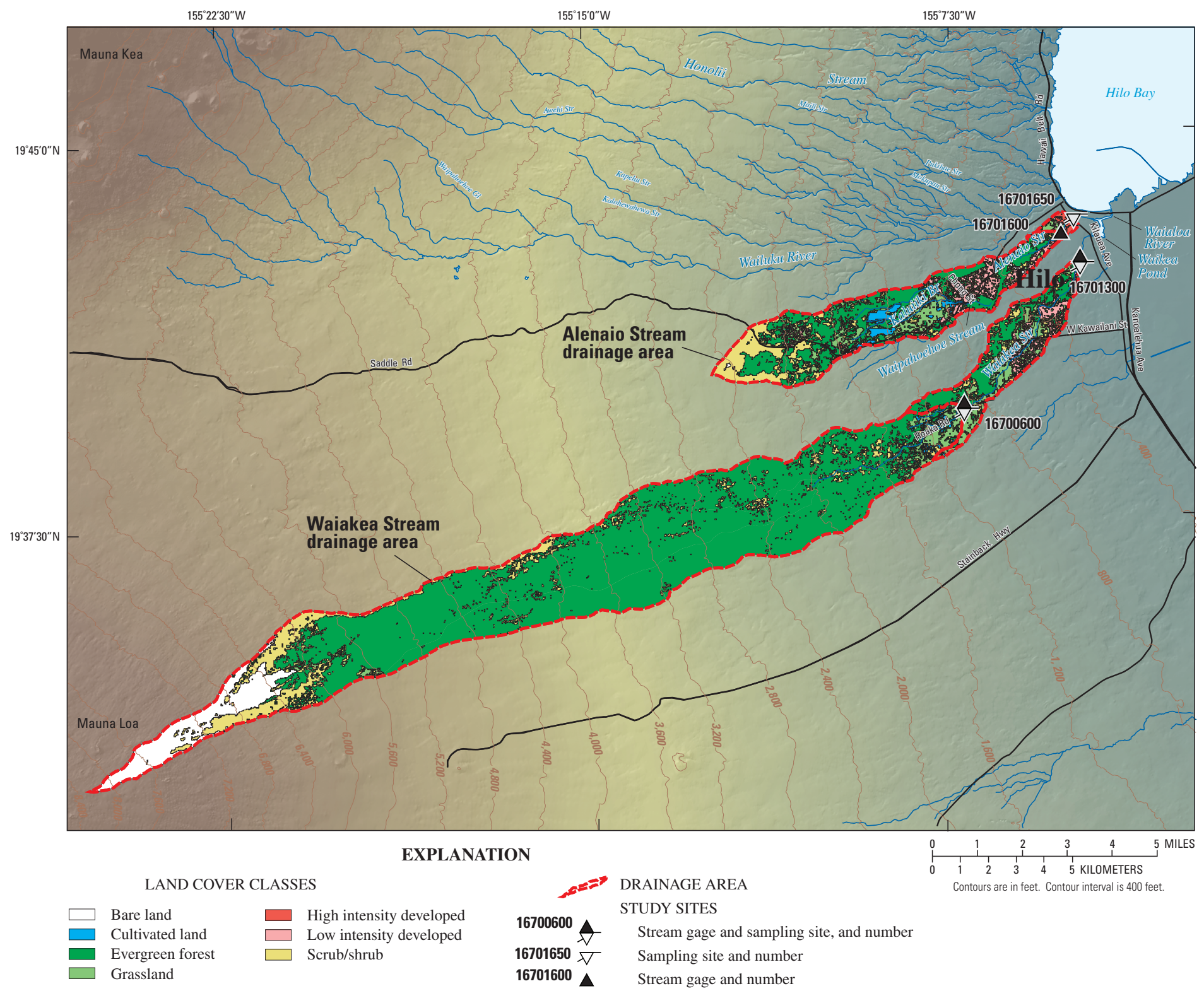

Figure 9. Map showing land cover classes within drainage areas of stream-gaging and sampling sites for this study, Hilo, Hawaii. 
Table 5. Chronology of data collection, number of days samples were collected, number of samples collected, and number storm events at sites on Waiakea and Alenaio

Streams, Hilo, Hawaii.

[cfs, cubic feet per second]

\begin{tabular}{|c|c|c|c|c|}
\hline Description & $\begin{array}{l}\text { Waiakea Stream at Hoaka Road } \\
(16700600)\end{array}$ & $\begin{array}{c}\text { Waiakea Stream at Hilo } \\
(16701300)\end{array}$ & $\begin{array}{c}\text { Alenaio Stream at Kilauea Avenue } \\
\text { Bridge } \\
(16701650)\end{array}$ & $\begin{array}{c}\text { Alenaio Stream at Hilo } \\
(16701600)\end{array}$ \\
\hline \multicolumn{5}{|c|}{ Begin and end dates for types of data } \\
\hline Daily-mean discharge & $10 / 01 / 2003$ to $10 / 11 / 2005$ & $10 / 01 / 2003$ to $10 / 14 / 2005$ & data not computed & $10 / 01 / 2004$ to $04 / 18 / 2006$ \\
\hline $\begin{array}{l}\text { Estimated daily-mean dis- } \\
\text { charge }\end{array}$ & $\begin{array}{l}06 / 25 / 2004 \text { to } 07 / 02 / 2004 \\
12 / 10 / 2004 \text { to } 01 / 06 / 2005\end{array}$ & $\begin{array}{l}10 / 01 / 2003 \text { to } 10 / 03 / 2003 \\
01 / 07 / 2005 \text { to } 02 / 04 / 2005\end{array}$ & data not computed & none \\
\hline $\begin{array}{l}\text { Daily-mean loads for } \\
\text { suspended sediment and } \\
\text { nutrients }\end{array}$ & $10 / 01 / 2003$ to $09 / 30 / 2005$ & $10 / 01 / 2003$ to $09 / 30 / 2005$ & data not computed & no sampling at this site \\
\hline Nutrient sampling & $03 / 14 / 2004$ to $03 / 30 / 2005$ & $03 / 14 / 2004$ to $03 / 30 / 2005$ & $11 / 09 / 2005$ to $03 / 09 / 2006$ & no sampling at this site \\
\hline $\begin{array}{l}\text { Suspended sediment sam- } \\
\text { pling }\end{array}$ & $03 / 14 / 2004$ to $08 / 07 / 2005$ & 03/14/2004 to $08 / 07 / 2005$ & $11 / 09 / 2005$ to $03 / 09 / 2006$ & no sampling at this site \\
\hline \multicolumn{5}{|c|}{ Number of sampling days } \\
\hline Suspended sediment & 21 & 11 & 3 & no sampling at this site \\
\hline Nutrients & 13 & 5 & 3 & no sampling at this site \\
\hline \multicolumn{5}{|c|}{ Number of samples } \\
\hline Suspended sediment & 156 & 78 & 33 & no sampling at this site \\
\hline Nutrients & 71 & 31 & 34 & no sampling at this site \\
\hline $\begin{array}{l}\text { Calibration for suspended } \\
\text { sediment }\end{array}$ & 5 & 1 & 3 & no sampling at this site \\
\hline Calibration for nutrients & 3 & 1 & 3 & no sampling at this site \\
\hline \multicolumn{5}{|c|}{ Number of storm events* } \\
\hline $\begin{array}{l}\text { Number of events with daily } \\
\text { mean discharge greater } \\
\text { than } 20 \text { cfs during duration } \\
\text { of discharge data }\end{array}$ & 13 & 7 & no discharge record at this site & 7 \\
\hline Number of sampled events & 11 & 6 & 3 & no sampling at this site \\
\hline $\begin{array}{l}\text { Number of sampled events } \\
\text { with daily mean discharge } \\
\text { greater than } 50 \mathrm{cfs}\end{array}$ & 8 & 4 & no discharge record at this site & no sampling at this site \\
\hline
\end{tabular}



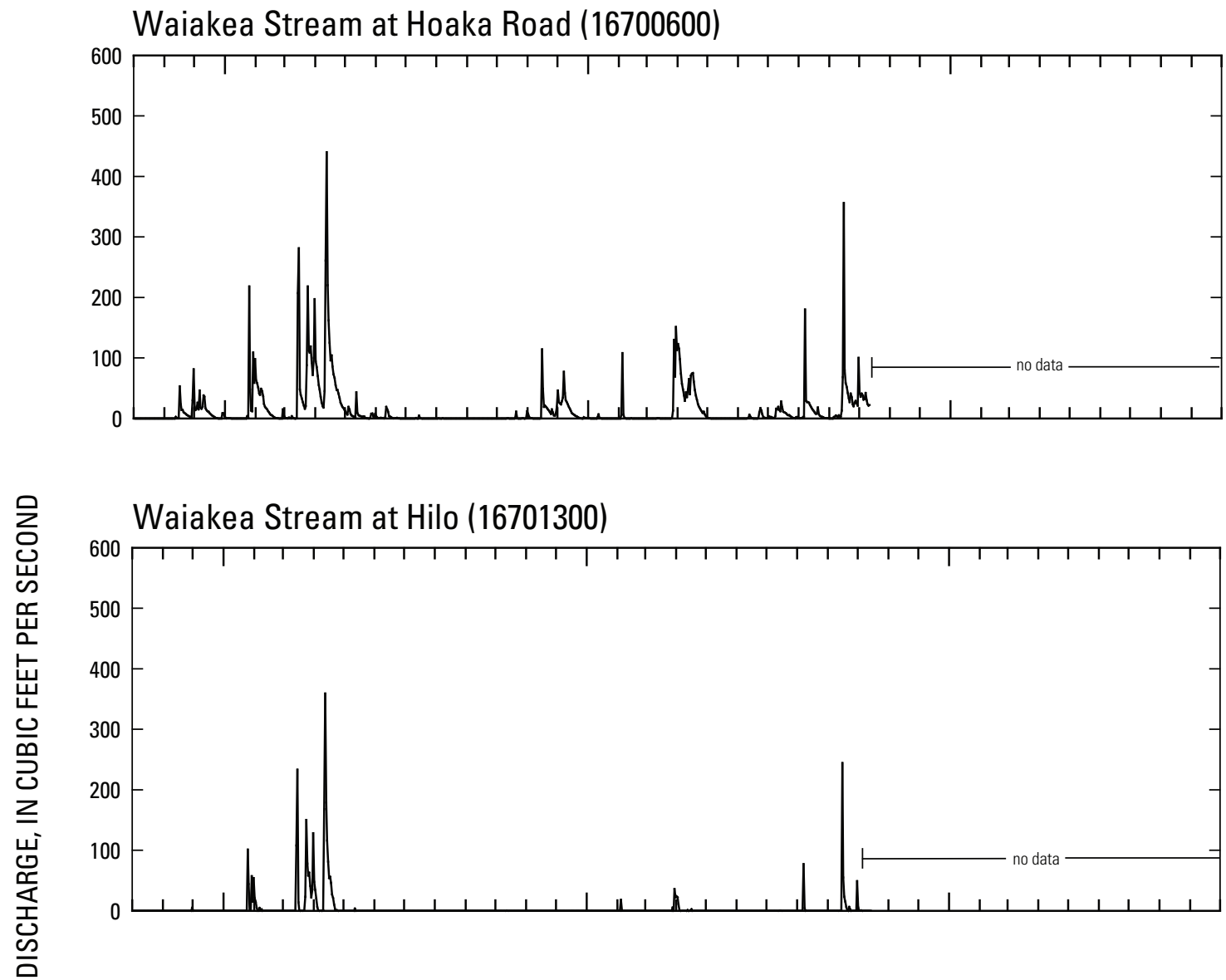

Alenaio Stream at Hilo (16701600)

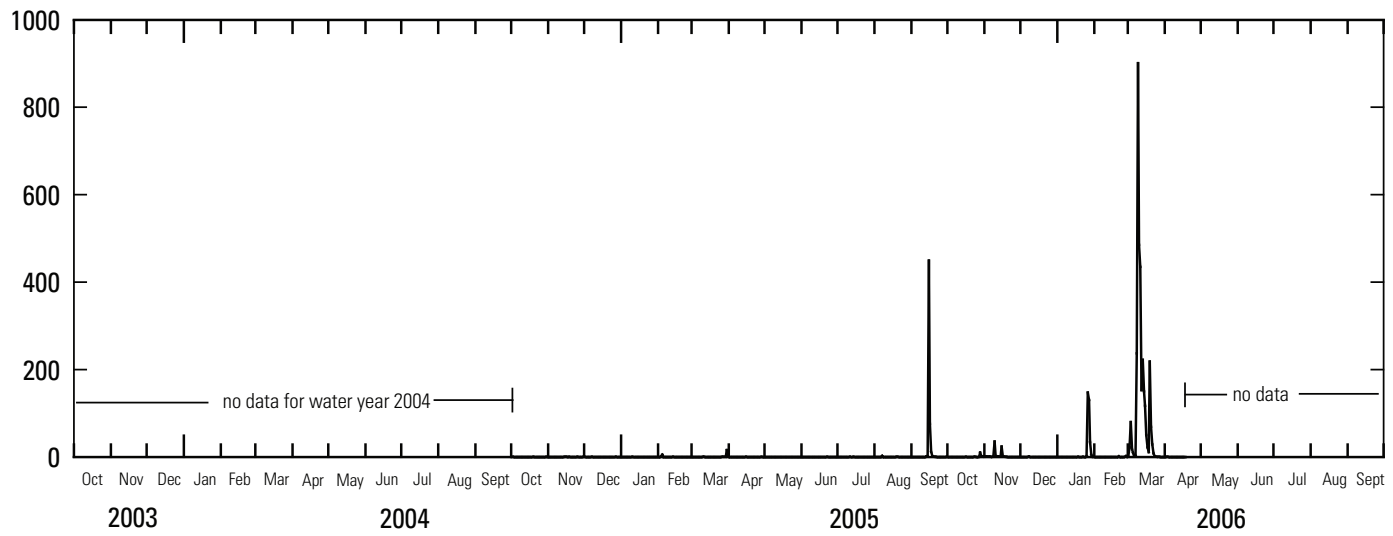

Figure 10. Daily-mean discharge for sites Waiakea Stream at Hoaka Road (16700600), Waiakea Stream at Hilo (16701300), and Alenaio Stream at Hilo (16701600), Hilo, Hawaii; October 1, 2003, to September 30, 2006. 
samples. During the sampling period, two dip samples were collected at the Waiakea sites when streamflow was high; these samples were not used to create cross-section coefficients.

Automated point samplers were used to collect water samples for suspended-sediment and nutrient concentration analyses at each of the three water-quality sites according to methods described by Edwards and Glysson (1999). Samples were collected using an automated point sampler that pumps water from a permanently installed orifice at the stream gage. The automated point samplers have the capacity to collect 24 1-liter bottles. The automated samplers were programmed to collect multiple suspended-sediment and nutrient samples during storms at intervals ranging from 5 minutes to 24 hours. In most cases, the samplers were triggered to sample by the electronic loggers that measured stream stage. The threshold stages for the samplers were variable, and were based on experience and storm forecasting. For example, during drier periods, the sampler thresholds were set at stages that were low to sample small events at lower flows. If a storm was forecasted, stage thresholds were set higher in an effort to sample over a longer period of the discharge peak; if the threshold was left set at a lower stage, the sampler would have filled up with samples early in the event. During some events, the sampler was triggered manually while field personnel monitored the change in stage of the event. By manually triggering the sampler, field personnel could sample over a longer period of the discharge peak and over a range of discharge.

Discharge-weighted samples were collected concurrently with automated point samples at the two Waiakea Stream sites and at Alenaio Stream at Kilauea Avenue Bridge to determine cross-section coefficients. Unfortunately, discharge-weighted samples were only collected during relatively low flows, and ideally, these should be collected over a larger range of discharge. However, streams tend to be well mixed at higher flows, thus minimizing differences between automated point samples and discharge-weighted samples.

Samples were collected over a period of 24 months from March 14, 2004, through March 9, 2006 (table 5). Field personnel concentrated their efforts on Waiakea Stream during the early part of the project, from March 14, 2004, to August 7, 2005, and then changed focus to sampling at Alenaio Stream at Kilauea Avenue Bridge and determining the stage / discharge relation at Alenaio Stream at Hilo during November 9, 2005, to March 9, 2006.

\section{Sample Processing, Physical Analysis, and Chemical Analysis}

Suspended-sediment samples were shipped to the USGS Cascades Volcanoes Observatory Sediment Laboratory in Vancouver, Washington for analysis. Concentrations were determined according to ASTM Standard Test Method D 3977-97, which includes retaining, drying at $103^{\circ} \mathrm{C}$, and weighing all of the sediment in a known mass of a water-sediment mixture
(Guy, 1969). Sediment concentrations were determined to the nearest $\mathrm{mg} / \mathrm{L}$. Concentrations of $100 \mathrm{mg} / \mathrm{L}$ and above are reported to 3 significant figures.

Nutrient samples were processed according to procedures in the USGS National Field Manual for the Collection of Water-Quality Data (Wilde and others, 1998). Processing and preservation chambers were used to reduce the potential for contamination from the surrounding environment during sample splitting, filtration, and preservation. Samples were chilled and shipped to the laboratory as quickly as possible. The temperature of the cooler and the date it was received were recorded at the laboratory. A record of all samples collected and shipped to a laboratory for analysis was maintained.

Nutrient samples were shipped to the USGS National Water Quality Laboratory (NWQL) in Arvada, Colorado for analysis. Concentrations were determined using semiautomated colorimetric methods (U.S. Environmental Protection Agency, 1983; Fishman, 1993; Patton and Truitt, 2000). Laboratory reporting limits were adequate for project requirements because the laboratory reporting limits are less than the minimum applicable state stream water-quality criteria.

Total nitrogen concentrations were computed as the sum of the concentrations of nitrogen, nitrite plus nitrate, dissolved, and total ammonia plus organic nitrogen (Kjeldahl). Although the analysis of nitrogen, nitrite plus nitrate, dissolved, is not directly comparable with the State of Hawaii's criteria for total nitrate plus nitrite nitrogen (defined as: the sum of total nitrate plus nitrite from an unfiltered sample, which may be filtered or centrifuged when extreme turbidity [threshold under development] indicates potential interference with analytical instruments), adding this sum to total ammonia plus organic nitrogen provides a satisfactory approximation of the State of Hawaii's criteria for total nitrogen, and meets the needs of $\mathrm{HDOH}$ for determining the degree of waterbody impairment. Furthermore, it also meets the needs of $\mathrm{HDOH}$ for developing TMDLs and pollutant load allocations for total nitrogen (David Penn, HDOH, written communication, 2004). Concentrations of nitrogen, nitrite plus nitrate, dissolved, are essentially equivalent to total nitrate plus nitrite because under normal conditions of $\mathrm{pH}$ and redox potential, nitrate and nitrite are completely dissolved in water (Hem, 1985).

\section{Data Analysis and Computation}

As mentioned before, stream load is a measure of the amount of constituent delivered by the stream, in tons or pounds (lbs), divided over a period of time, in days. In order to calculate loads, the concentration of the constituent, in milligram per liter $(\mathrm{mg} / \mathrm{L})$ or other concentration unit, is multiplied by discharge, in cubic feet per second (cfs), and a conversion factor. Daily-mean loads are the mean of the unit-value loads, derived from the concentrations of samples, estimates of concentration based on discharge, and the unit value (15 minute interval) discharge recordings over each day. The Appendix shows the methods used for these calculations. 
Instantaneous loads were calculated for all samples from the three sampling sites, when discharge data was available. Daily-mean loads were computed for water years 2004 and 2005 for sites Waiakea Stream at Hoaka Road and Waiakea Stream at Hilo. Since a continuous record of discharge was not possible to compute at Alenaio Stream at Kilauea Avenue Bridge, no daily-mean load record was computed.

For the two Waiakea Stream sites, cross-section sample concentrations were compared to samples from the automatic sampler to determine cross-section coefficients (Edwards and Glysson, 1999). The cross-section coefficients are shown for each constituent, by site, in table 6. Different cross-section coeffiecients were used for suspended sediment for water year 2004 and 2005 at the upper Waiakea Stream site. For nutrient constituents at Waiakea Stream at Hoaka Road, and both suspended sediment and nutrient constituents at Waiakea Stream at Hilo, each constituent used the same cross-section coefficient for water years 2004 and 2005.

The data, after adjustment using the cross-section coefficients, showed weak correlations between discharge and concentration for suspended sediment and nutrients. At Waiakea Stream at Hoaka Road, a suitable regression or 'sediment transport curve' for suspended sediment (table 6) was developed and used to help create estimated points in GCLAS. However, no suitable regressions were developed for Waiakea Stream at Hilo due to the poor correlation. The regression equations for transport curves for total nitrogen, dissolved nitrate plus nitrite, and total phosphorus were not developed for the two sites, also due to poor correlation.

Sediment and nutrient (total nitrogen, total phosphorus, and dissolved nitrate plus nitrite) loads were computed following the methods described by Porterfield (1972), and by using the Graphical Constituent Loading Analysis System (GCLAS) software package (Koltun and others, 2006). GCLAS graphically displays samples and discharge, and allows the user to estimate constituent concentrations based on the peaks and troughs of discharge. GCLAS allows the user to interpolate the data through time between the estimated and/or actual points. Not all constituents behave the same way relative to discharge, in fact, for a given site, the concentration pattern for one storm or discharge event may differ from that of another, even if the discharge was similar (Porterfield, 1972). As shown in figure 11 , this method creates a practical estimate of concentration.

Cross-section sample data, adjusted automated point sampler data, and suitable sediment transport curves were loaded into GCLAS. For the two sites on Waiakea Stream, the number of estimates for each water year are listed in table 6. GCLAS is capable of outputting unit values and daily mean values of concentration and load data. Daily-mean concentration data, unit value (15 minute) concentration data, and unit-value load data are not provided in this report, but are available by request.

\section{Streamflow}

Streamflow at Waiakea and Alenaio Streams is ephemeral and flashy. Streamflow data for two sites on Waiakea Stream and one site on Alenaio Stream show many long periods of zero flow (fig. 10).

For Waiakea Stream, discharge is generally greater and longer in duration at the higher altitude site, Waiakea Stream at Hoaka Road, than at the lower site, Waiakea Stream at Hilo. Also, streamflow resulted from more storms at the upper site than at the lower site. Contributing factors to the greater discharge at the upper site than the lower site include (1) higher rainfall at higher altitudes (Giambelluca and others, 1986) and (2) the reach between the two sites has exposed lava tubes within the channel and loses substantial flow. The reaches below the natural channel may lose water along the stream bed, but have been extensively modified; the walls of the channel are fortified, and the stream gains water from storm drains and other urban runoff during the early portion of runoff events. These stream characteristics also affect the duration of the discharge events at each site; the lower site returns to little or no flow more quickly than the upper site.

Along Alenaio Stream, discharge was about the same at both the lower site and the upper site during three of the sampling events (fig. 12). Discharge data from these two sites were derived by highly different methods, yet they agree within reason. However, it was found that during some localized storms, there was sufficient flow at the lower site to sample for nutrients and suspended sediment while there was little or no flow at the upper site. Similar to Waiakea Stream, Alenaio Stream has numerous storm drains that drain into the lower channelized part of the stream, which may add to runoff during the early part of storms.

\section{Hydrologic Setting at the Time of Sampling}

The collection of water-quality data requires additional information and data to put the sampled storms in perspective and context. Data from nearby raingages and long-term stream gages assist interpretation in this way, and are presented here as an example or starting point for further study.

Rainfall is measured by the National Weather Service at many locations within or adjacent to the study area. Presented here are data from three locations within or near the study area: Hilo Airport (altitude: $28 \mathrm{ft}$ ), Piihonua (altitude: 860 $\mathrm{ft}$ ) and Waiakea Uka (altitude: 1,000 ft). Discharge and stage have been measured at over a dozen sites in the Hilo area; of interest to this report are two discontinued gages on Waiakea Stream; Waiakea Stream near Mountain View (station number 16700000) and Waiakea Stream near Hilo (station number 16701200), and two sites that are still in operation mentioned earlier; Honolii Stream near Papaikou and Wailuku River at Piihonua. Figure 1 and table 7 shows locations and periods of record for each of these stations. Figure 13 shows discharge at the sites in this study as well as discharge at Honolii Stream 
Table 6. Number of samples used, number of estimates used, cross-section coefficient values, and transport curve equations used for estimating daily-mean load records at Waiakea Stream at Hoaka Road (16700600) and Waiakea Stream at Hilo (16701300), during water years 2004 and 2005.

[cfs, cubic feet per second; Q, discharge, in cfs; wy, water year]

\begin{tabular}{|c|c|c|}
\hline Description & $\begin{array}{l}\text { Waiakea Stream at Hoaka Road } \\
(16700600)\end{array}$ & $\begin{array}{c}\text { Waiakea Stream at Hilo } \\
(16701300)\end{array}$ \\
\hline Number of samples used, wy 2004 & 51 & 50 \\
\hline Number of samples used, wy 2005 & 157 & 26 \\
\hline Number of estimates used, wy 2005 & 134 & 66 \\
\hline $\begin{array}{l}\text { Cross-section coefficient for suspended sedi- } \\
\text { ment samples, wy } 2005\end{array}$ & 2.25 & 1.17 \\
\hline Sediment transport curve equation, wy 2004 & $\log (\operatorname{conc})=0.67 \times \log (Q)-0.53$ & poor correlation, not developed \\
\hline Number of estimates used, wy 2004 & 167 & 105 \\
\hline Number of samples used, wy 2005 & 56 & 22 \\
\hline Number of estimates used, wy 2005 & 128 & 49 \\
\hline $\begin{array}{l}\text { Cross-section coefficient for total nitrogen } \\
\text { samples, wy } 2004 \text { and } 2005\end{array}$ & 0.95 & 0.90 \\
\hline
\end{tabular}

Transport curve equation, wy 2004

Transport curve equation, wy 2005

negative and weak correlation, not developed postive and weak correlation, not developed negative and weak correlation, not developed postive and weak correlation, not developed Nitrogen, Nitrite + Nitrate, Dissolved Daily-Mean Load Compuations

Number of samples used, wy 2004

Number of estimates used, wy 2004

Number of samples used, wy 2005

Number of estimates used, wy 2005

Cross-section coefficient for nitrogen, nitrite + nitrate, dissolved samples, wy 2004 and 2005

Transport curve equation, wy 2004

Transport curve equation, wy 2005

$\begin{array}{cc}8 & 7 \\ 173 & 97 \\ 56 & 22 \\ 107 & 47 \\ & \\ 0.97 & 1.00\end{array}$

negative and weak correlation, not developed negative and weak correlation, not developed negative and weak correlation, not developed negative and weak correlation, not developed Total Phosphorus Daily-Mean Load Compuations

Number of samples used, wy 2004

Number of estimates used, wy 2004

$\begin{array}{cc}8 & 7 \\ 210 & 97 \\ 56 & 22 \\ 131 & 52 \\ & \\ 1.06 & 0.84\end{array}$

negative and weak correlation, not developed

postive and weak correlation, not developed negative and weak correlation, not developed postive and weak correlation, not developed 

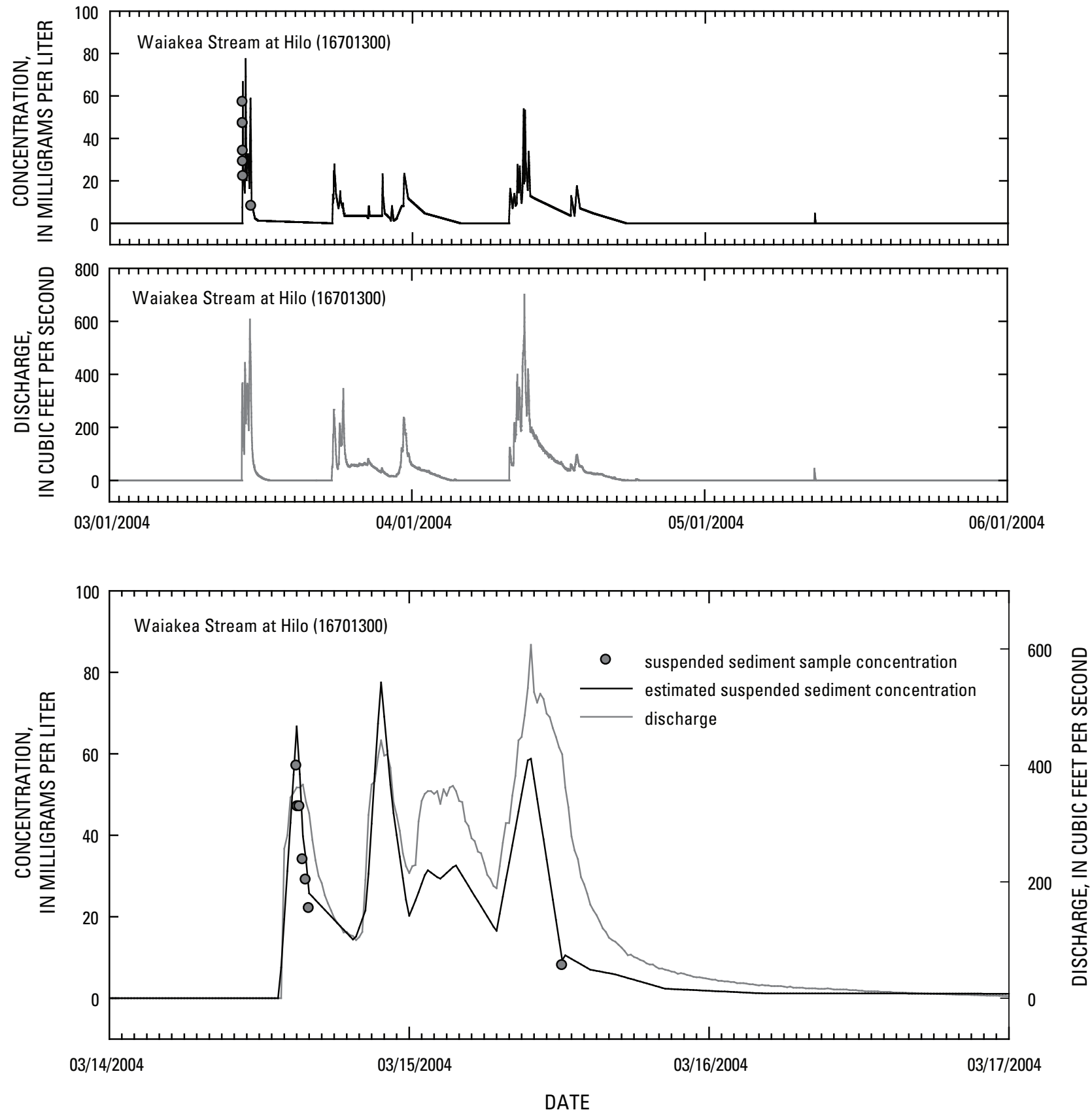

Figure 11. Discharge, suspended sediment sample concentration, estimated suspended sediment concentration, and discharge for Waiakea Stream at Hilo (16701300), Hilo, Hawaii, during March 1 to June 1, 2004, and detail of March 14 to March 17, 2004. 
November 9, 2005
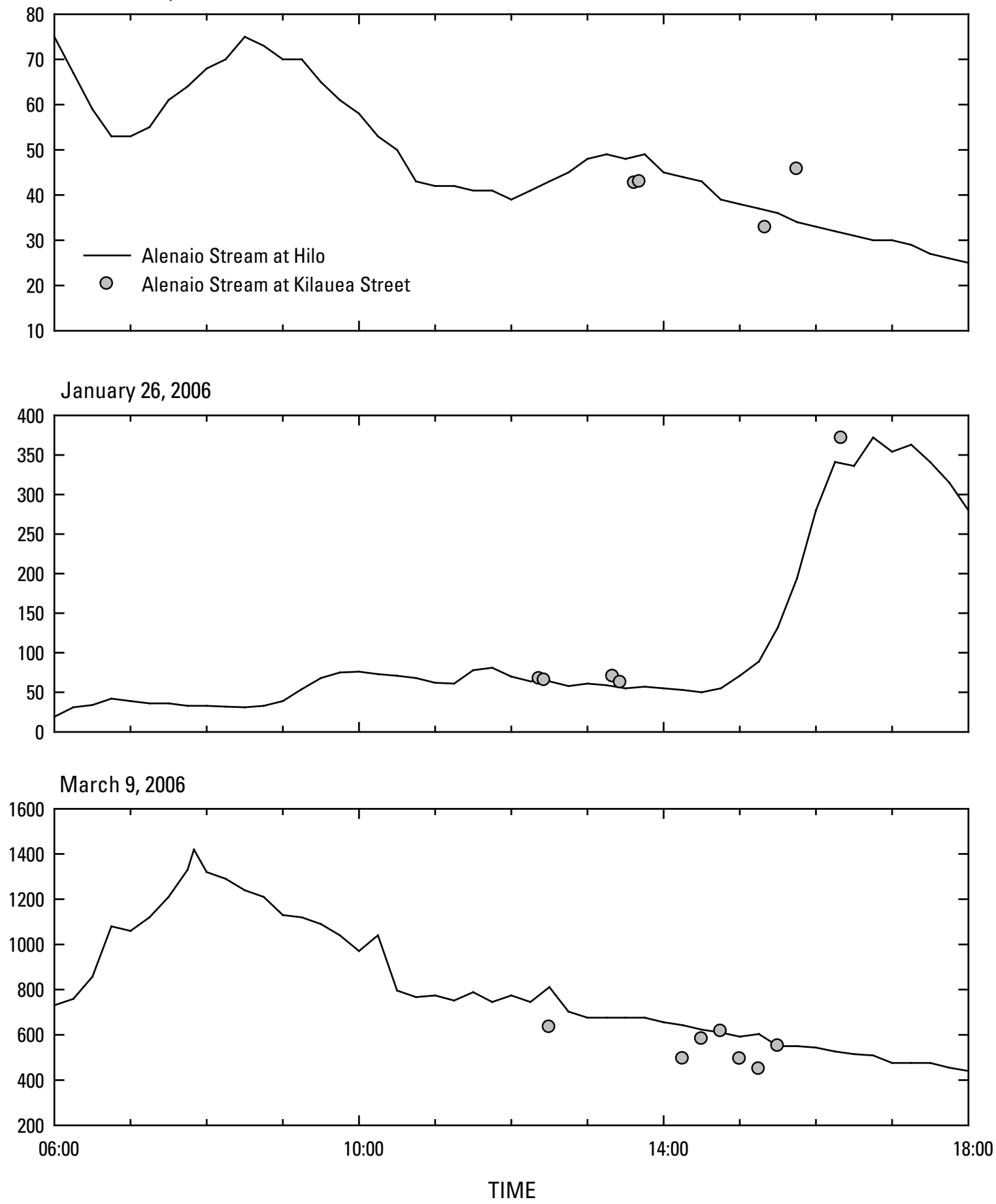

Figure 12. Discharge at Alenaio Stream at Hilo (16701600) and discharge measurements made at Alenaio Stream at Kilauea Avenue Bridge (16701650), during November 9, 2005, January 26, 2006, and March 9, 2006, Hilo, Hawaii. 
near Papaikou and Wailuku River at Piihonua over seven water years.

Lower than normal rainfall and streamflow throughout the study period may have reduced the amount of sediment being washed into streams as well as constituents, such as phosphorus, that attach to sediment particles. Figure 14 shows monthly rainfall for four years, including the years of this study, as percent departure from the mean monthly rainfall for the period of record, as well as daily-mean discharge at Honolii Stream near Papaikou, with the $25^{\text {th }}$ and $75^{\text {th }}$ percentile daily discharge for the period of record (shown as a light blue band). For reference, figure 14 also shows the dates of the samples relative to the rainfall and Honolii Stream discharge hydrographs.

Data analyses, such as event rainfall intensities, flowduration curves for the three sites of this report, as well as for other long-term stations in the general vicinity, and criteria to determine duration of a storm event, are required to define the conditions for each sampled event. Although the criteria for defining storm events was not developed for this study, the data suggests that about 13 storm events occurred at Waiakea Stream at Hoaka Road over the period of discharge record from October 1, 2003, to October 11, 2005, and about 7 events occurred at Alenaio Stream at Hilo from October 1, 2004, to April 18, 2006. Table 5 shows the number of 'storm events' sampled, based visual inspection of the hydrographs, at the three sampling sites. Further analyses and definition may increase the number of storm events if each peak is considered a storm.

\section{Concentrations and Instantaneous Loads of Suspended Sediment and Nutrients}

A total of 267 suspended sediment samples and 136 nutrient samples were collected at both sites on Waiakea Stream and the lower site on Alenaio Stream between March 14, 2004, and March 9, 2006. Table 5 shows the number of sampling dates, and the numbers of individual suspendedsediment and nutrient samples collected for each site.

Tables 8, 10, and 12 list suspended sediment concentrations and instantaneous loads for times when only suspended sediment samples were collected (no nutrient analyses). Tables 9, 11, and 13 list concentrations and instantaneous loads for times when both suspended sediment and nutrient samples were collected.

Concentrations of suspended sediment at Waiakea Stream at Hoaka Road range from 1 to $201 \mathrm{mg} / \mathrm{L}$, and instantaneous loads range from 0.02 to 363 tons/day (table 8 and 9). Total nitrogen concentrations range from 0.14 to $29 \mathrm{mg} / \mathrm{L}$, and instantaneous loads range from 5.3 to 7,400 lbs/day (table 9). Concentrations of nitrogen, as nitrite plus nitrate, dissolved, range from 0.011 to $0.200 \mathrm{mg} / \mathrm{L}$, and instantaneous loads range from 1.2 to $238 \mathrm{lbs} /$ day. Phosphorus concentrations range from 0.006 to $3.12 \mathrm{mg} / \mathrm{L}$, and instantaneous loads range from 0.23 to $850 \mathrm{lbs} /$ day.

At Waiakea Stream at Hilo, concentration of suspended sediment range from 1 to $1,430 \mathrm{mg} / \mathrm{L}$, and instantaneous loads range from 0.03 to 1,010 tons/day (table 10 and 11). Total nitrogen concentration range from 0.21 to $1.0 \mathrm{mg} / \mathrm{L}$, and instantaneous loads range from 5.7 to 2,000 lbs/day (table 11). Concentrations of nitrogen, as nitrite plus nitrate, dissolved, range from 0.014 to $0.121 \mathrm{mg} / \mathrm{L}$, and instantaneous loads

Table 7. Altitude, drainage area, and period of record for additional stream gaging stations and National Weather Service rain gages presented in this report, Hilo, Hawaii.

[ft, feet; msl, mean sea level; $\mathrm{mi}^{2}$, square miles]

\begin{tabular}{|c|c|c|c|c|c|c|}
\hline \multirow{2}{*}{$\begin{array}{l}\text { Station } \\
\text { Number }\end{array}$} & \multirow{2}{*}{ Station Name } & \multirow{2}{*}{$\begin{array}{c}\text { Altitude } \\
\text { (ft above } \\
\text { msl) }\end{array}$} & \multirow{2}{*}{$\begin{array}{c}\text { Drainage } \\
\text { Area } \\
\left(\mathrm{mi}^{2}\right)\end{array}$} & \multicolumn{2}{|c|}{ Period of Record } & \multirow{2}{*}{ Status } \\
\hline & & & & Begin & End & \\
\hline \multicolumn{7}{|c|}{ Stream Gaging Stations } \\
\hline 16700000 & Waiakea Stream nr Mountain View, HI & 1940 & 17.4 & Oct-1930 & Sep-1991 & discontinued station \\
\hline 16701200 & Waiakea Stream near Hilo, HI & 370 & 33.6 & Jun-1957 & Jun-1967 & discontinued station \\
\hline \multicolumn{7}{|c|}{ National Weather Service Rain Gages } \\
\hline NWS \# 511492 & Hilo Airport & 28 & -- & Oct-1949 & present & current station \\
\hline NWS \# 518053 & Piihonua & 860 & -- & Mar-1991 & present & current station \\
\hline NWS \# 519084 & Waiakea Uka & 1000 & -- & Mar-1991 & present & current station \\
\hline
\end{tabular}



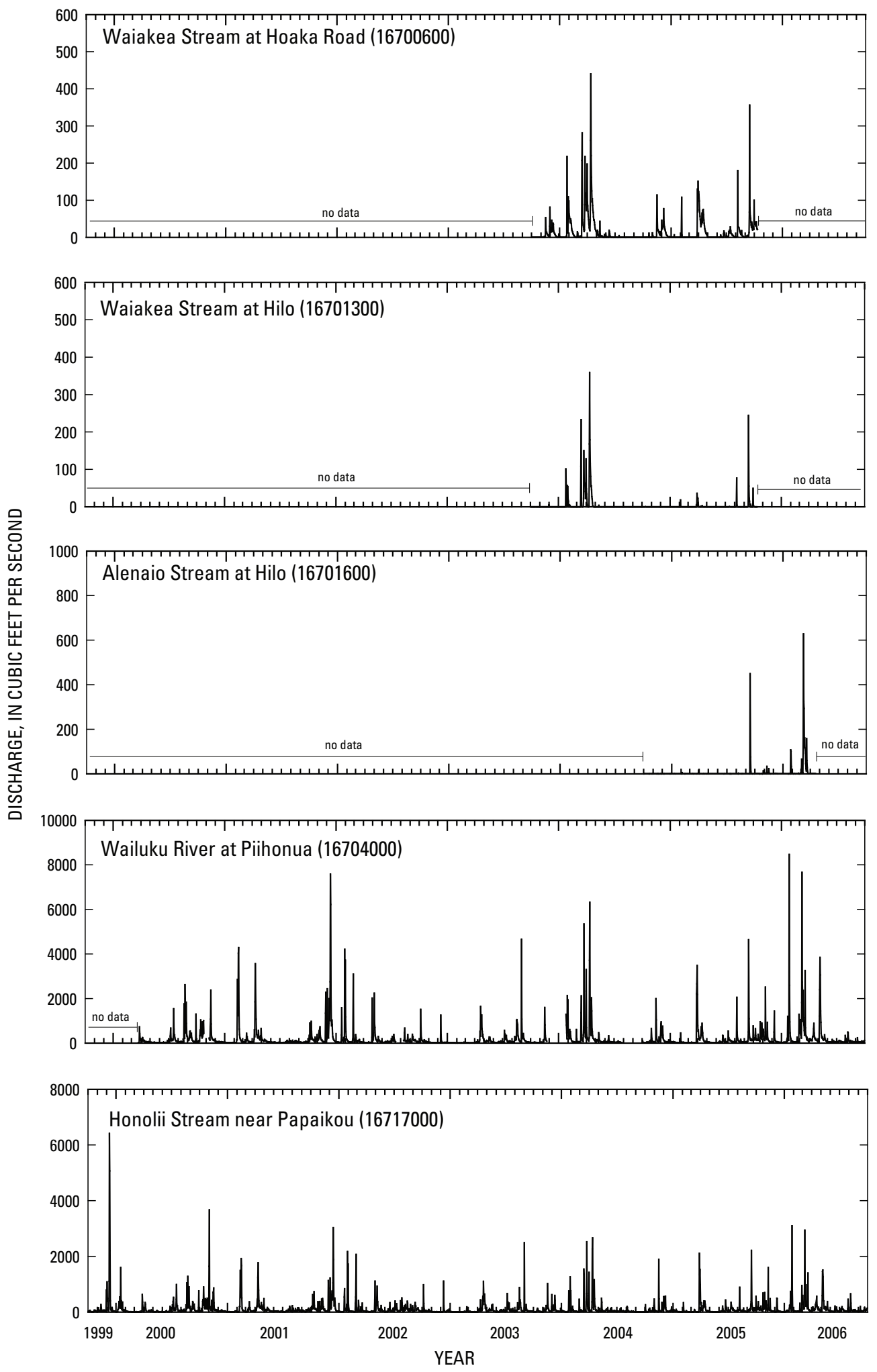

Figure 13. Daily-mean discharge for sites Waiakea Stream at Hoaka Road (16700600), Waiakea Stream at Hilo (16701300), Alenaio Stream at Hilo (16701600), Wailuku River at Piihonua (16704000), and Honolii Stream near Papaikou (16717000, Hilo, Hawaii; October 1, 2003, to September 30, 2005. 

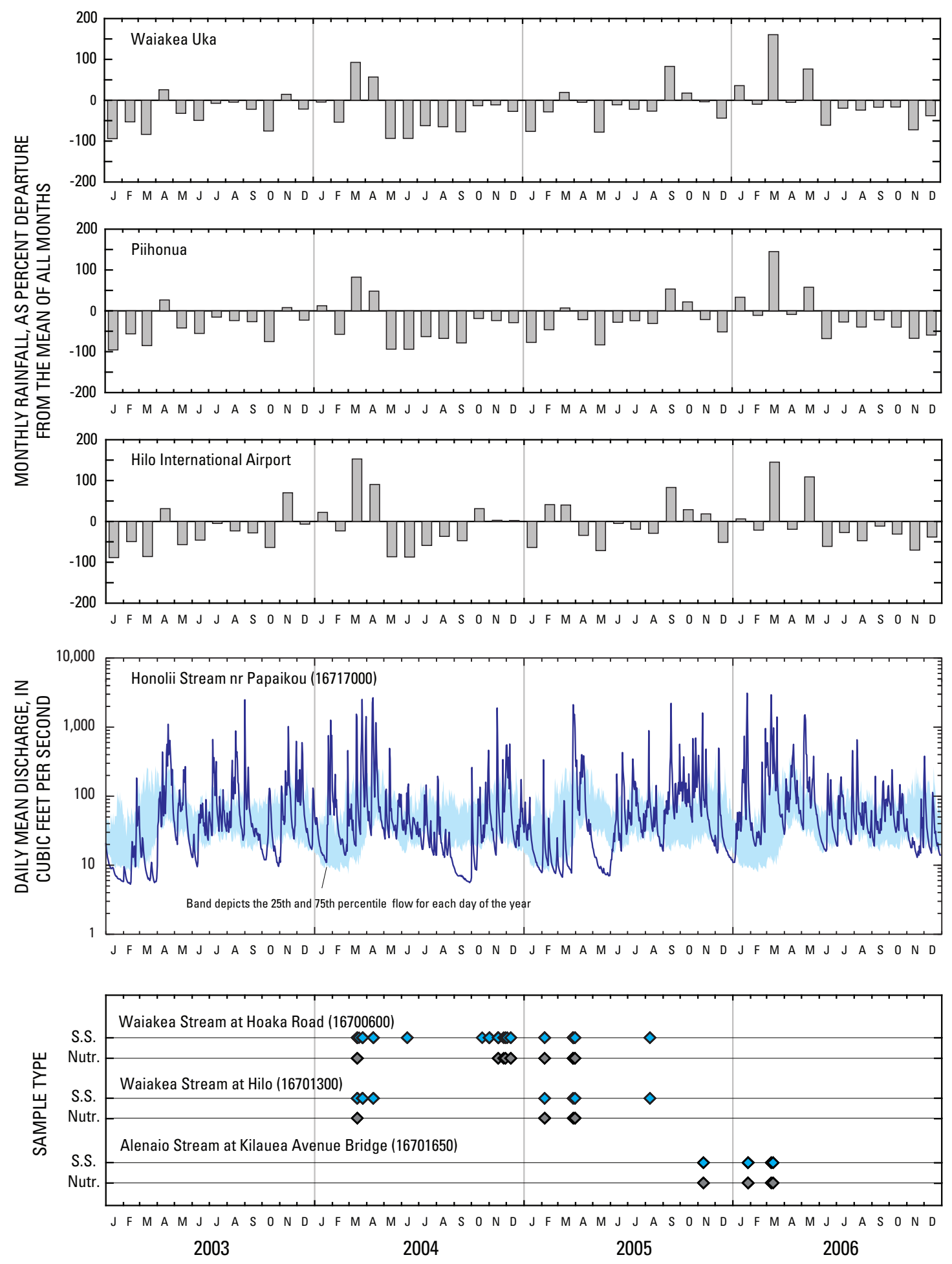

Figure 14. Monthly rainfall, as percent departure from mean-monthly rainfall, for three National Weather Service rain gages in or near study area; discharge at gaging station Honolii Stream near Papaikou (16717000), with band delineating 25th and 75th percentile flow, and sampling dates for suspended sediment and nutrients at study sites, during 2003 to 2006, Hilo, Hawaii. 
Table 8. Discharge, concentration and instantaneous loads of suspended sediment, for samples collected without associated nutrient analyses, from March 15, 2004, to August 7, 2005, Waiakea Stream at Hoaka Road (16700600), Hilo, Hawaii.

[hh:mm, hours and minutes; Conc., concentration; Load, computed from concentration value and discharge value for each sample; $\mathrm{ft}^{3} / \mathrm{s}$, cubic feet per second; $\mathrm{mg} / \mathrm{L}$, milligrams per liter; lbs/day, pounds per day]

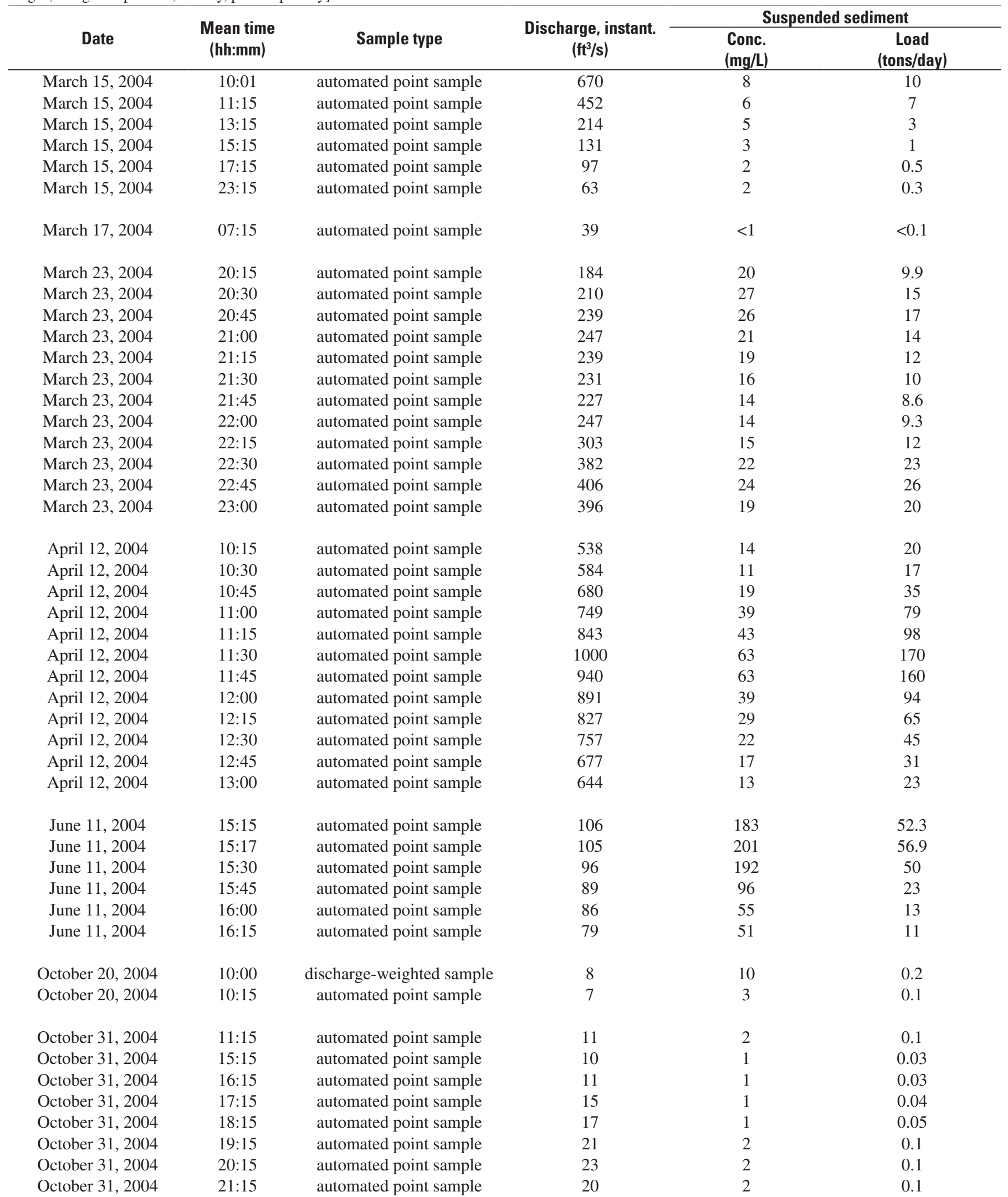


Table 8. Discharge, concentration and instantaneous loads of suspended sediment, for samples collected without associated nutrient analyses, from March 15, 2004, to August 7, 2005, Waiakea Stream at Hoaka Road (16700600), Hilo, Hawaii.—Continued.

[hh:mm, hours and minutes; Conc., concentration; Load, computed from concentration value and discharge value for each sample; ft $3 / \mathrm{s}$, cubic feet per second; $\mathrm{mg} / \mathrm{L}$, milligrams per liter; lbs/day, pounds per day]

\begin{tabular}{|c|c|c|c|c|c|}
\hline Date & $\begin{array}{l}\text { Mean time } \\
\text { (hh:mm) }\end{array}$ & Sample type & $\begin{array}{l}\text { Discharge, instant. } \\
\qquad\left(\mathrm{ft}^{3} / \mathbf{s}\right)\end{array}$ & \multicolumn{2}{|c|}{ Suspended sediment } \\
\hline October 31, 2004 & $22: 15$ & automated point sample & 18 & 2 & 0.1 \\
\hline November 1, 2004 & $00: 15$ & automated point sample & 14 & 2 & 0.1 \\
\hline November 1, 2004 & $01: 15$ & automated point sample & 13 & 2 & 0.1 \\
\hline November 1, 2004 & $04: 15$ & automated point sample & 10 & 1 & 0.03 \\
\hline November 1, 2004 & $05: 15$ & automated point sample & 9 & 1 & 0.02 \\
\hline November 1, 2004 & $06: 15$ & automated point sample & 8 & 1 & 0.02 \\
\hline November 15, 2004 & $10: 49$ & automated point sample & 150 & 5 & 2 \\
\hline November 15, 2004 & $13: 30$ & automated point sample & 161 & 4 & 2 \\
\hline November 15, 2004 & $14: 30$ & automated point sample & 140 & 4 & 2 \\
\hline November 15, 2004 & $15: 30$ & automated point sample & 109 & 3 & 0.9 \\
\hline November 15, 2004 & $16: 30$ & automated point sample & 122 & 3 & 1 \\
\hline November 15, 2004 & $17: 30$ & automated point sample & 156 & 7 & 3 \\
\hline November 15, 2004 & $18: 30$ & automated point sample & 161 & 3 & 1 \\
\hline November 15, 2004 & $19: 20$ & automated point sample & 141 & 5 & 2 \\
\hline November 15, 2004 & $20: 30$ & automated point sample & 113 & 2 & 0.6 \\
\hline November 15, 2004 & $21: 30$ & automated point sample & 111 & 2 & 0.6 \\
\hline November 15, 2004 & $22: 30$ & automated point sample & 103 & 2 & 0.6 \\
\hline November 15, 2004 & $23: 30$ & automated point sample & 89 & 3 & 0.7 \\
\hline November 16, 2004 & $07: 30$ & automated point sample & 60 & 2 & 0.3 \\
\hline November 16, 2004 & $08: 30$ & automated point sample & 58 & 1 & 0.2 \\
\hline November 16, 2004 & $09: 30$ & automated point sample & 54 & 3 & 0.4 \\
\hline November 16, 2004 & $10: 30$ & automated point sample & 50 & 1 & 0.1 \\
\hline November 30, 2004 & $11: 00$ & automated point sample & 19 & 3 & 0.2 \\
\hline November 30, 2004 & $11: 05$ & discharge-weighted sample & 19 & 7 & 0.4 \\
\hline November 30, 2004 & 11:07 & automated point sample & 19 & 5 & 0.3 \\
\hline February 4, 2005 & 01:30 & automated point sample & 292 & 11 & 8.7 \\
\hline February 4, 2005 & $10: 53$ & automated point sample & 51 & 3 & 0.4 \\
\hline February 4, 2005 & $11: 00$ & automated point sample & 50 & 5 & 0.7 \\
\hline February 4, 2005 & 11:04 & automated point sample & 50 & 2 & 0.3 \\
\hline March 27, 2005 & $09: 46$ & automated point sample & 3 & 2 & 0.02 \\
\hline March 27, 2005 & $10: 45$ & automated point sample & 6 & 2 & 0.03 \\
\hline March 28, 2005 & 09:40 & automated point sample & 99 & 4 & 1 \\
\hline
\end{tabular}


Table 8. Discharge, concentration and instantaneous loads of suspended sediment, for samples collected without associated nutrient analyses, from March 15, 2004, to August 7, 2005, Waiakea Stream at Hoaka Road (16700600), Hilo, Hawaii.-Continued. [hh:mm, hours and minutes; Conc., concentration; Load, computed from concentration value and discharge value for each sample; $\mathrm{ft}^{3} / \mathrm{s}$, cubic feet per second; $\mathrm{mg} / \mathrm{L}$, milligrams per liter; lbs/day, pounds per day]

\begin{tabular}{|c|c|c|c|c|c|}
\hline Date & $\begin{array}{l}\text { Mean time } \\
\text { (hh:mm) }\end{array}$ & Sample type & $\begin{array}{l}\text { Discharge, instant. } \\
\qquad\left(\mathrm{ft}^{3} / \mathrm{s}\right)\end{array}$ & \multicolumn{2}{|c|}{ Suspended sediment } \\
\hline March 28, 2005 & $09: 45$ & automated point sample & 99 & 5 & 1 \\
\hline August 7, 2005 & $10: 00$ & automated point sample & 412 & 99 & 110 \\
\hline August 7, 2005 & $10: 30$ & automated point sample & 814 & 146 & 320 \\
\hline August 7, 2005 & $12: 00$ & automated point sample & 707 & 71 & 140 \\
\hline August 7, 2005 & $12: 30$ & automated point sample & 535 & 51 & 74 \\
\hline
\end{tabular}

range from 1.5 to $86 \mathrm{lbs} /$ day. Phosphorus concentrations range from 0.021 to $0.174 \mathrm{mg} / \mathrm{L}$, and instantaneous loads range from 0.46 to $340 \mathrm{lbs} /$ day.

At Alenaio Stream at Kilauea Avenue Bridge, concentration of suspended sediment range from 5 to $182 \mathrm{mg} / \mathrm{L}$, and instantaneous loads range from 0.8 to 48 tons/day (table 12 and 13). Total nitrogen concentration range from 0.24 to 0.84 $\mathrm{mg} / \mathrm{L}$, and instantaneous loads range from 43 to 1,100 lbs/day (table 13). Concentrations of nitrogen, as nitrite plus nitrate, dissolved, range from 0.011 to $0.141 \mathrm{mg} / \mathrm{L}$, and instantaneous loads range from 13 to $451 \mathrm{lbs} /$ day. Phosphorus concentration range from 0.015 to $0.194 \mathrm{mg} / \mathrm{L}$, and instantaneous loads range from 3.2 to $130 \mathrm{lbs} /$ day.

It is important to note that the concentration and instantaneous load values, listed in these tables, were not adjusted based on the cross-section coefficients. Adjusted data were used for the computation of daily-mean loads.

Table 14 provides statistics for stream discharge, concentration and instantaneous loads. For Waiakea Stream, higher concentrations and loads of suspended sediment and nutrients were found at Waiakea Stream at Hoaka Road than at the downstream site Waiakea Stream at Hilo. At Alenaio Stream at Kilauea Avenue Bridge, only 12 of the nutrient samples had associated discharge measurements. The period of sampling for this site does not overlap the period of sampling at the two Waiakea sites.

\section{Daily-Mean Loads of Suspended Sediment and Nutrients}

This section presents the daily-mean load data for the two Waiakea sites. Within the hydrographs of the data (figs. 15a, $15 \mathrm{~b}, 16 \mathrm{a}$ and $16 \mathrm{~b}$ ), the dates of the samples are also shown. Within the tables, the monthly total discharge data are also provided. Daily-mean load data are also available in electronic format.

Daily-mean loads, although estimated, can be used to calculate a total tonnage of the analyzed constituents that have passed by at the sampling / discharge site. The units for dailymean load values are actually provided in tons, thus, by simply adding up the daily-mean loads, event, monthly, or annual totals can be calculated.

Unit-value data.-Unit-value discharge, concentration and load data were computed as part of the process to create daily-mean loads. Unit-value data, in this case, 15-minute interval data as shown in figure 11, can be used to estimate the tonnage of constituent delivered during a given storm event. In addition, the sampling methodology provides important information regarding the change in concentration relative to changes in discharge during storm events. As mentioned before, some constituents do not behave in a linear relation to discharge, and in some cases the peak concentration of a given constituent can occur before or after the peak in discharge (Porterfield, 1972). Unit-value discharge, concentration and load data are also available upon request.

\section{Waiakea Stream at Hoaka Road (16700600)}

Daily-mean loads of suspended-sediment and nutrient constituents for Waiakea Stream at Hoaka Road for water years 2004 and 2005 are shown in figures 15a and 15b, and tables 15a and b, 16a and b, 17a and b, and 18a and b. In addition, tables of daily-mean discharge are also provided (tables 19a, b, and c).

\section{Suspended Sediment}

Daily-mean loads of suspended-sediment varied from 0.00 to 79 tons/day over the period of record. Since discharge 
Table 9. Discharge, concentration, and instantaneous loads of nutrients and suspended sediment samples collected from March 14, 2004, to March 30, 2005, Waiakea Stream at Hoaka Road (16700600), Hilo, Hawaii.

[hh:mm, hours and minutes; Conc., concentration; Load, computed from concentration value and discharge value for each sample; e, value is estimated; --, not analyzed or measured; fts, cubic feet per second; mg/L,milligrams per liter; lbs/day, pounds per day]

\begin{tabular}{|c|c|c|c|c|c|c|c|c|c|c|c|}
\hline \multirow[b]{2}{*}{ Date } & \multirow[b]{2}{*}{$\begin{array}{c}\text { Mean time } \\
\text { (hh:mm) }\end{array}$} & \multirow[b]{2}{*}{ Sample type } & \multirow{2}{*}{$\begin{array}{c}\text { Discharge, } \\
\text { instant. } \\
\left(\mathrm{ft}^{3} / \mathrm{s}\right)\end{array}$} & \multicolumn{2}{|c|}{ Total nitrogen ${ }^{a}$} & \multicolumn{2}{|c|}{$\begin{array}{l}\text { Nitrogen, nitrite + } \\
\text { nitrate, dissolved }\end{array}$} & \multicolumn{2}{|c|}{ Total phosphorus } & \multicolumn{2}{|c|}{ Suspended sediment } \\
\hline & & & & $\begin{array}{l}\text { Conc. } \\
\text { (mg/L } \\
\text { as N) }\end{array}$ & $\begin{array}{l}\text { Load } \\
\text { (lbs/ } \\
\text { day) }\end{array}$ & $\begin{array}{l}\text { Conc. } \\
\text { (mg/L } \\
\text { as N) }\end{array}$ & $\begin{array}{l}\text { Load } \\
\text { (Ibs/ } \\
\text { day) }\end{array}$ & $\begin{array}{l}\text { Conc. } \\
\text { (mg/L } \\
\text { as P) }\end{array}$ & $\begin{array}{c}\text { Load } \\
\text { (Ibs/day) }\end{array}$ & $\begin{array}{l}\text { Conc. } \\
\text { (mg/L) }\end{array}$ & $\begin{array}{l}\text { Load } \\
\text { (tons/ } \\
\text { day) }\end{array}$ \\
\hline March 14, 2004 & $13: 30$ & automated point sample & 684 & 0.55 & 2,000 & 0.026 & 96 & 0.149 & 550 & 60 & 100 \\
\hline March 14, 2004 & $13: 35$ & automated point sample & 684 & 1.0 & 3,700 & 0.028 & 100 & 0.143 & 528 & 57 & 110 \\
\hline March 14, 2004 & $13: 45$ & automated point sample & 677 & 0.54 & 2,000 & 0.025 & 91 & 0.114 & 416 & 46 & 84 \\
\hline March 14, 2004 & $14: 00$ & automated point sample & 608 & 0.64 & 2,100 & 0.023 & 75 & 0.095 & 310 & 36 & 59 \\
\hline March 14, 2004 & $14: 15$ & automated point sample & 551 & 0.51 & 1,500 & 0.023 & 68 & 0.078 & 230 & 24 & 37 \\
\hline March 14, 2004 & $14: 30$ & automated point sample & 503 & 0.50 & 1,400 & 0.022 & 60 & 0.070 & 190 & 24 & 33 \\
\hline March 15, 2004 & $11: 00$ & dip sample & 503 & 0.22 & 600 & 0.036 & 98 & 0.029 & 79 & 5 & 7 \\
\hline March 15, 2004 & 11:01 & automated point sample & 504 & 0.19 & 520 & 0.034 & 92 & 0.031 & 84 & -- & -- \\
\hline October 20, 2004 & 09:30 & automated point sample & 6.5 & 0.16 & 5.6 & 0.037 & 1.3 & 0.012 & 0.42 & -- & -- \\
\hline October 20, 2004 & $09: 35$ & discharge-weighted sample & 6.5 & 0.15 & 5.3 & 0.034 & 1.2 & 0.013 & 0.46 & -- & -- \\
\hline October 20, 2004 & $09: 45$ & automated point sample & 8 & 0.20 & 8.6 & 0.036 & 2 & 0.011 & 0.5 & -- & -- \\
\hline November 15, 2004 & 03:00 & automated point sample & 47 & 29 & 7,400 & 0.086 & 22 & 3.12 & 790 & 10 & 1 \\
\hline November 15, 2004 & 03:05 & automated point sample & 47 & 0.46 & 120 & 0.088 & 22 & 0.034 & 8.6 & 9 & 1 \\
\hline November 15, 2004 & $03: 15$ & automated point sample & 66 & 0.64 & 130 & 0.108 & 38 & 0.048 & 17 & 18 & 3.2 \\
\hline November 15, 2004 & $03: 30$ & automated point sample & 47 & 0.76 & 190 & 0.105 & 27 & 0.065 & 16 & 28 & 3.5 \\
\hline November 15, 2004 & $03: 45$ & automated point sample & 99 & 0.68 & 360 & 0.095 & 51 & 0.081 & 43 & 34 & 9.1 \\
\hline November 15, 2004 & 04:00 & automated point sample & 103 & 0.60 & 330 & 0.088 & 49 & 0.071 & 39 & 20 & 6 \\
\hline November 15, 2004 & $10: 33$ & automated point sample & 149 & 0.28 & 220 & 0.038 & 31 & 0.021 & 17 & -- & -- \\
\hline November 15, 2004 & $10: 35$ & discharge-weighted sample & 149 & 0.25 & 200 & 0.043 & 35 & 0.022 & 18 & -- & -- \\
\hline November 15, 2004 & $10: 44$ & discharge-weighted sample & 149 & 0.25 & 200 & 0.038 & 31 & 0.020 & 16 & -- & -- \\
\hline November 25, 2004 & $09: 45$ & automated point sample & 23 & 0.26 & 32 & 0.077 & 9.6 & 0.042 & 5.2 & 1 & 0.1 \\
\hline November 25, 2004 & $10: 30$ & automated point sample & 25 & $\mathrm{e} 0.17$ & $\mathrm{e} 23$ & 0.097 & 13 & 0.006 & 0.8 & 2 & 0.1 \\
\hline November 29, 2004 & $22: 15$ & automated point sample & 24 & 2.2 & 280 & 0.113 & 15 & 0.170 & 22 & 16 & 1 \\
\hline November 29, 2004 & $22: 20$ & automated point sample & 24 & 0.33 & 43 & 0.067 & 8.7 & 0.017 & 2.2 & 3 & 0.2 \\
\hline November 29, 2004 & $22: 30$ & automated point sample & 26 & 0.21 & 29 & 0.073 & 10 & 0.008 & 1 & 3 & 0.2 \\
\hline November 29, 2004 & $22: 45$ & automated point sample & 28 & 0.18 & 27 & 0.073 & 11 & 0.009 & 1 & 4 & 0.3 \\
\hline November 29, 2004 & $23: 00$ & automated point sample & 29 & 0.30 & 47 & 0.073 & 11 & 0.015 & 2.3 & 5 & 0.4 \\
\hline November 29, 2004 & $23: 15$ & automated point sample & 30 & 0.18 & 29 & 0.069 & 11 & 0.009 & 1 & 3 & 0.2 \\
\hline November 30, 2004 & $10: 48$ & automated point sample & 19 & 0.17 & 17 & 0.036 & 3.7 & 0.012 & 1.2 & -- & -- \\
\hline November 30, 2004 & $10: 50$ & discharge-weighted sample & 19 & 0.15 & 15 & 0.037 & 3.8 & 0.009 & 0.9 & -- & -- \\
\hline November 30, 2004 & $10: 51$ & automated point sample & 19 & 0.14 & 14 & 0.038 & 3.9 & 0.008 & 0.8 & -- & -- \\
\hline
\end{tabular}


Table 9. Discharge, concentration, and instantaneous loads of nutrients and suspended sediment samples collected from March 14, 2004, to March 30, 2005, Waiakea Stream at Hoaka Road (16700600), Hilo, Hawaii._Continued.

[hh:mm, hours and minutes; Conc., concentration; Load, computed from concentration value and discharge value for each sample; e, value is estimated; --, not analyzed or measured; fťs, cubic feet per second; mg/L,milligrams per liter; lbs/day, pounds per day]

\begin{tabular}{|c|c|c|c|c|c|c|c|c|c|c|c|}
\hline \multirow[b]{2}{*}{ Date } & \multirow[b]{2}{*}{$\begin{array}{l}\text { Mean time } \\
\text { (hh:mm) }\end{array}$} & \multirow[b]{2}{*}{ Sample type } & \multirow{2}{*}{$\begin{array}{c}\text { Discharge, } \\
\text { instant. } \\
\left(\mathrm{ft}^{3} / \mathrm{s}\right)\end{array}$} & \multicolumn{2}{|c|}{ Total nitrogen $^{a}$} & \multicolumn{2}{|c|}{$\begin{array}{l}\text { Nitrogen, nitrite + } \\
\text { nitrate, dissolved }\end{array}$} & \multicolumn{2}{|c|}{ Total phosphorus } & \multicolumn{2}{|c|}{ Suspended sediment } \\
\hline & & & & $\begin{array}{l}\text { Conc. } \\
\text { (mg/L } \\
\text { as N) }\end{array}$ & $\begin{array}{l}\text { Load } \\
\text { (Ibs/ } \\
\text { day) } \\
\end{array}$ & $\begin{array}{l}\text { Conc. } \\
\text { (mg/L } \\
\text { as N) }\end{array}$ & $\begin{array}{l}\text { Load } \\
\text { (Ibs/ } \\
\text { day) } \\
\end{array}$ & $\begin{array}{l}\text { Conc. } \\
(\mathrm{mg} / \mathrm{L} \\
\text { as } \mathrm{P}) \\
\end{array}$ & $\begin{array}{c}\text { Load } \\
\text { (lbs/day) }\end{array}$ & $\begin{array}{l}\text { Conc. } \\
\text { (mg/L) }\end{array}$ & $\begin{array}{c}\text { Load } \\
\text { (tons/ } \\
\text { day) } \\
\end{array}$ \\
\hline December 7, 2004 & $14: 15$ & automated point sample & 182 & $\mathrm{e} 0.45$ & e440 & $\mathrm{e} 0.011$ & e11 & 0.076 & 75 & 31 & 15 \\
\hline December 7, 2004 & $14: 20$ & automated point sample & 180 & 0.70 & 680 & 0.017 & 17 & 0.096 & 93 & 32 & 16 \\
\hline December 7, 2004 & $14: 45$ & automated point sample & 172 & $\mathrm{e} 0.28$ & e260 & $\mathrm{e} 0.014$ & $\mathrm{e} 13$ & 0.030 & 28 & 24 & 11 \\
\hline December 7, 2004 & $15: 15$ & automated point sample & 155 & 0.27 & 230 & 0.027 & 23 & 0.027 & 23 & 16 & 6.7 \\
\hline December 7, 2004 & $15: 45$ & automated point sample & 147 & 0.23 & 180 & 0.028 & 22 & 0.019 & 15 & 11 & 4.4 \\
\hline December 7, 2004 & $16: 15$ & automated point sample & 135 & 0.21 & 150 & 0.029 & 21 & 0.017 & 12 & 7 & 3 \\
\hline February 3, 2005 & $23: 30$ & automated point sample & 115 & 9.6 & 6,000 & 0.195 & 121 & 1.37 & 850 & 35 & 11 \\
\hline February 3, 2005 & $23: 35$ & automated point sample & 115 & 0.90 & 560 & 0.200 & 100 & 0.102 & 63.3 & 38 & 12 \\
\hline February 4, 2005 & 00:00 & automated point sample & 313 & 0.75 & 1,300 & 0.200 & 238 & 0.104 & 176 & 91 & 77 \\
\hline February 4, 2005 & 00:30 & automated point sample & 315 & 0.55 & 930 & 0.200 & 167 & 0.059 & 100 & 26 & 22 \\
\hline February 4, 2005 & 01:00 & automated point sample & 308 & 0.48 & 800 & 0.200 & 154 & 0.049 & 81 & 17 & 14 \\
\hline February 4, 2005 & $10: 30$ & automated point sample & 55 & 0.43 & 130 & 0.200 & 18 & 0.049 & 15 & -- & -- \\
\hline February 4, 2005 & $10: 35$ & discharge-weighted sample & 54 & 0.18 & 52 & 0.200 & 17 & 0.013 & 3.8 & -- & -- \\
\hline February 4, 2005 & $10: 45$ & automated point sample & 53 & 0.85 & 240 & 0.200 & 18 & 0.011 & 3.1 & -- & -- \\
\hline March 27, 2005 & $09: 45$ & automated point sample & 2.9 & 0.36 & 5.6 & 0.118 & 1.8 & 0.017 & 0.27 & 2 & 0.02 \\
\hline March 27, 2005 & 09:50 & automated point sample & 2.9 & 0.34 & 5.3 & 0.109 & 1.7 & 0.015 & 0.23 & -- & -- \\
\hline March 27, 2005 & $10: 15$ & automated point sample & 4.9 & 0.26 & 6.9 & 0.090 & 2.4 & 0.016 & 0.42 & 2 & 0.03 \\
\hline March 27, 2005 & $11: 15$ & automated point sample & 5.5 & 0.21 & 6.2 & 0.062 & 1.8 & 0.014 & 0.41 & 2 & 0.03 \\
\hline March 27, 2005 & $11: 45$ & automated point sample & 5.5 & -- & -- & -- & -- & 0.016 & 0.47 & 2 & 0.03 \\
\hline March 28, 2005 & 09:30 & automated point sample & 98 & 0.18 & 95 & 0.029 & 15 & 0.015 & 7.9 & -- & -- \\
\hline March 28, 2005 & $09: 34$ & discharge-weighted sample & 98 & 0.17 & 90 & 0.023 & 12 & 0.017 & 9.0 & -- & -- \\
\hline March 28, 2005 & $09: 38$ & automated point sample & 98 & 0.15 & 79 & 0.023 & 12 & 0.015 & 7.9 & -- & -- \\
\hline March 28, 2005 & $10: 30$ & automated point sample & 115 & 0.19 & 120 & 0.038 & 24 & 0.018 & 11 & 4 & 4 \\
\hline March 28, 2005 & $10: 35$ & automated point sample & 115 & 0.18 & 110 & 0.036 & 22 & 0.017 & 11 & 4 & 4 \\
\hline March 28, 2005 & $11: 00$ & automated point sample & 194 & 0.22 & 230 & 0.028 & 29 & 0.028 & 29 & 10 & 5.0 \\
\hline March 28, 2005 & $11: 30$ & automated point sample & 227 & 0.36 & 440 & 0.034 & 42 & 0.051 & 62 & 18 & 11 \\
\hline March 28, 2005 & $12: 00$ & automated point sample & 237 & 0.39 & 500 & 0.032 & 41 & 0.049 & 63 & 21 & 13 \\
\hline March 28, 2005 & $12: 30$ & automated point sample & 243 & 0.41 & 540 & 0.026 & 34 & 0.063 & 83 & 25 & 16 \\
\hline March 28, 2005 & $13: 00$ & automated point sample & 220 & 0.29 & 340 & 0.031 & 37 & 0.063 & 75 & 23 & 14 \\
\hline March 28, 2005 & $13: 30$ & automated point sample & 192 & 0.36 & 370 & 0.032 & 33 & 0.058 & 60 & 21 & 11 \\
\hline March 28, 2005 & $14: 00$ & automated point sample & 175 & 0.32 & 300 & 0.033 & 31 & 0.039 & 37 & 13 & 6.1 \\
\hline March 28, 2005 & $14: 30$ & automated point sample & 166 & 0.18 & 160 & 0.024 & 21 & 0.024 & 21 & 9 & 4 \\
\hline March 28, 2005 & $15: 00$ & automated point sample & 161 & 0.19 & 160 & 0.024 & 21 & 0.020 & 17 & 6 & 3 \\
\hline March 28, 2005 & $15: 30$ & automated point sample & 155 & 0.21 & 180 & 0.034 & 28 & 0.019 & 16 & 6 & 3 \\
\hline
\end{tabular}


Table 9. Discharge, concentration, and instantaneous loads of nutrients and suspended sediment samples collected from March 14, 2004, to March 30, 2005, Waiakea Stream at Hoaka Road (16700600), Hilo, Hawaii.-Continued.

[hh:mm, hours and minutes; Conc., concentration; Load, computed from concentration value and discharge value for each sample; e, value is estimated; --, not analyzed or measured; fts, cubic feet per second; $\mathrm{mg} / \mathrm{L}$,milligrams per liter; lbs/day, pounds per day]

\begin{tabular}{|c|c|c|c|c|c|c|c|c|c|c|c|}
\hline \multirow[b]{2}{*}{ Date } & \multirow[b]{2}{*}{$\begin{array}{l}\text { Mean time } \\
\text { (hh:mm) }\end{array}$} & \multirow[b]{2}{*}{ Sample type } & \multirow{2}{*}{$\begin{array}{c}\text { Discharge, } \\
\text { instant. } \\
\left(\mathrm{ft}^{3} / \mathrm{s}\right)\end{array}$} & \multicolumn{2}{|c|}{ Total nitrogen ${ }^{a}$} & \multicolumn{2}{|c|}{$\begin{array}{l}\text { Nitrogen, nitrite + } \\
\text { nitrate, dissolved }\end{array}$} & \multicolumn{2}{|c|}{ Total phosphorus } & \multicolumn{2}{|c|}{ Suspended sediment } \\
\hline & & & & $\begin{array}{l}\text { Conc. } \\
\text { (mg/L } \\
\text { as N) }\end{array}$ & $\begin{array}{l}\text { Load } \\
\text { (Ibs/ } \\
\text { day) }\end{array}$ & $\begin{array}{l}\text { Conc. } \\
\text { (mg/L } \\
\text { as N) }\end{array}$ & $\begin{array}{l}\text { Load } \\
\text { (Ibs/ } \\
\text { day) }\end{array}$ & $\begin{array}{l}\text { Conc. } \\
\text { (mg/L } \\
\text { as P) }\end{array}$ & $\begin{array}{c}\text { Load } \\
\text { (lbs/day) }\end{array}$ & $\begin{array}{l}\text { Conc. } \\
\text { (mg/L) }\end{array}$ & $\begin{array}{l}\text { Load } \\
\text { (tons/ } \\
\text { day) }\end{array}$ \\
\hline March 30, 2005 & $00: 30$ & automated point sample & 130 & 0.18 & 130 & 0.059 & 41 & 0.016 & 11 & 4 & 1 \\
\hline March 30, 2005 & $00: 35$ & automated point sample & 138 & 0.23 & 170 & 0.060 & 45 & 0.018 & 13 & 5 & 2 \\
\hline March 30, 2005 & 01:00 & automated point sample & 235 & 0.28 & 350 & 0.054 & 68 & 0.030 & 38 & 10 & 6.0 \\
\hline March 30, 2005 & 01:30 & automated point sample & 277 & 0.31 & 460 & 0.050 & 75 & 0.046 & 69 & 15 & 11 \\
\hline March 30, 2005 & 02:00 & automated point sample & 268 & 0.25 & 360 & 0.043 & 62 & 0.030 & 43 & 11 & 8.0 \\
\hline March 30, 2005 & $02: 30$ & automated point sample & 257 & 0.22 & 304 & 0.037 & 51 & 0.029 & 40 & 10 & 7.0 \\
\hline
\end{tabular}

${ }^{\mathrm{a}}$ Total nitrogen is calculated by adding nitrogen, total organic + ammonia (Kjeldahl), to nitrogen, nitrite + nitrate, dissolved. If the concentration value of nitrogen, nitrite + nitrate, dissolved,

is estimated and below the minimum reporting level, the concentration value of total nitrogen is reported as the sum of the values shown for nitrogen, total organic + ammonia (Kjeldahl) and nitrogen, nitrite + nitrate, dissolved, and noted as estimated. 
Table 10. Discharge, concentration, and instantaneous loads of suspended sediment, for samples collected without associated nutrient analyses, from March 15, 2004, to August 7, 2005, Waiakea Stream at Hilo (16701300), Hilo, Hawaii.

[hh:mm, hours and minutes; Conc., concentration; Load, computed from concentration value and discharge value for each sample; $\mathrm{ft}^{3} / \mathrm{s}$, cubic feet per second; $\mathrm{mg} / \mathrm{L}$,milligrams per liter; lbs/day, pounds per day]

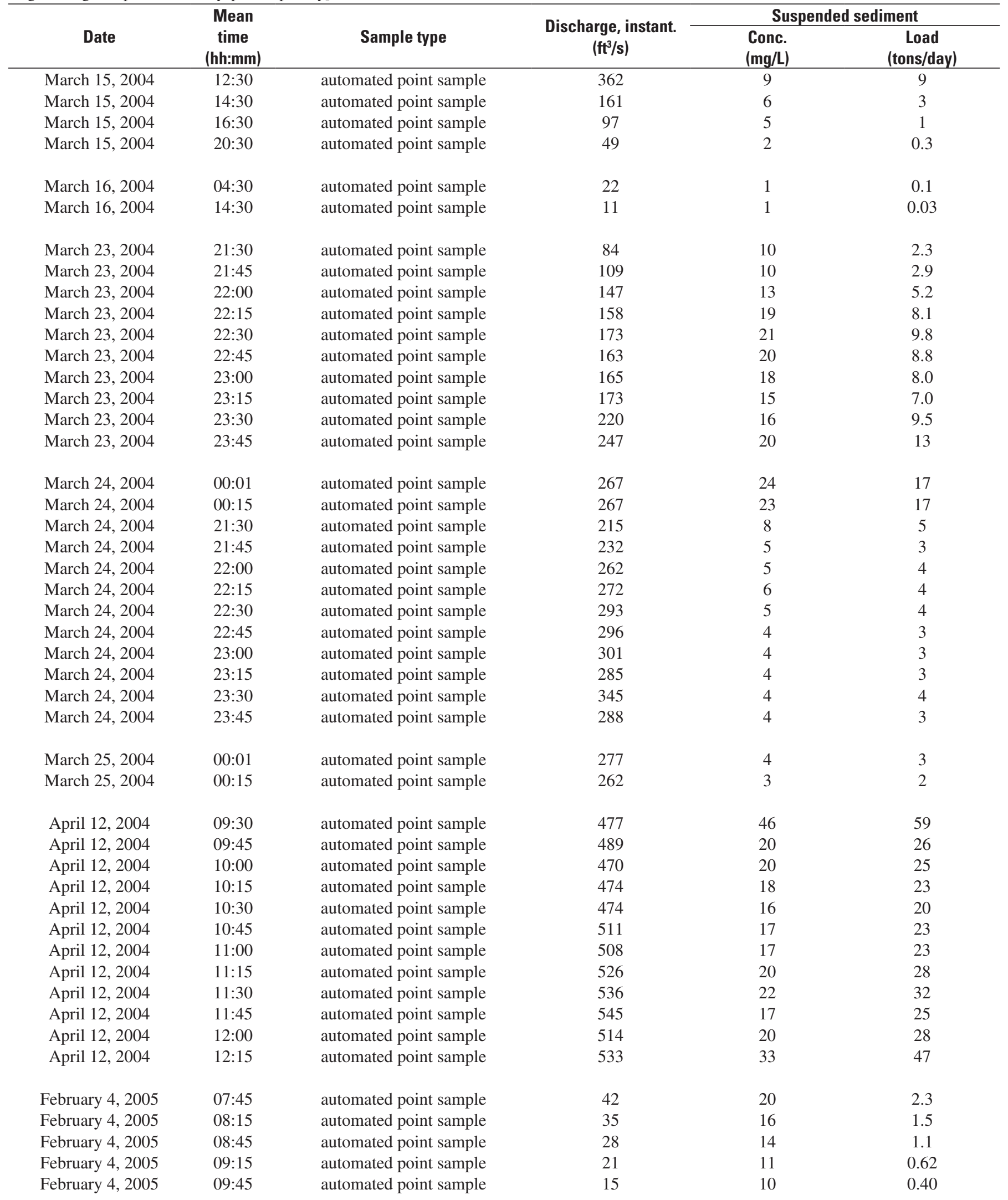


Table 10. Discharge, concentration, and instantaneous loads of suspended sediment, for samples collected without associated nutrient analyses, from March 15, 2004, to August 7, 2005, Waiakea Stream at Hilo (16701300), Hilo, Hawaii.—Continued.

[hh:mm, hours and minutes; Conc., concentration; Load, computed from concentration value and discharge value for each sample; $\mathrm{ft}^{3} / \mathrm{s}$, cubic feet per second; mg/L,milligrams per liter; lbs/day, pounds per day]

\begin{tabular}{|c|c|c|c|c|c|}
\hline \multirow[b]{2}{*}{ Date } & \multirow{2}{*}{$\begin{array}{c}\text { Mean } \\
\text { time } \\
\text { (hh:mm) }\end{array}$} & \multirow[b]{2}{*}{ Sample type } & \multirow[b]{2}{*}{$\begin{array}{l}\text { Discharge, instant. } \\
\qquad\left(\mathrm{ft}^{3} / \mathrm{s}\right)\end{array}$} & \multicolumn{2}{|c|}{ Suspended sediment } \\
\hline & & & & $\begin{array}{l}\text { Conc. } \\
\text { (mg/L) }\end{array}$ & $\begin{array}{c}\text { Load } \\
\text { (tons/day) }\end{array}$ \\
\hline February 4, 2005 & $10: 15$ & automated point sample & 9.3 & 8 & 0.2 \\
\hline March 30, 2005 & $12: 02$ & automated point sample & 62 & 12 & 2.0 \\
\hline March 30, 2005 & $12: 05$ & discharge-weighted sample & 62 & 14 & 2.3 \\
\hline August 7, 2005 & $11: 15$ & automated point sample & 143 & 463 & 179 \\
\hline August 7, 2005 & $11: 30$ & automated point sample & 262 & 1430 & 1010 \\
\hline August 7, 2005 & $12: 00$ & automated point sample & 334 & 780 & 703 \\
\hline August 7, 2005 & $12: 15$ & automated point sample & 359 & 654 & 633 \\
\hline August 7, 2005 & $12: 30$ & automated point sample & 452 & 624 & 761 \\
\hline
\end{tabular}

was zero for a majority of the days during the period of record, the median value of mean-daily load for suspended sediment was zero. The annual load of suspended sediment during water year 2004 was 522 tons, and the annual load during water year 2005 was 298 tons.

\section{Nutrients}

Daily-mean loads of total nitrogen, dissolved nitrite plus nitrate, and total phosphorus varied from 0.00 to $1,350,0.00$ to 13 , and 0.00 to $300 \mathrm{lbs} /$ day, respectively, over the period of record. Since discharge was zero for a majority of the days during the period of record, the median value of mean-daily load for all of these constituents was zero. The annual loads for total nitrogen, dissolved nitrite plus nitrate, and total phosphorus during water year 2004 were 9,650, 328, and 1,430 lbs. The annual loads for total nitrogen, dissolved nitrite plus nitrate, and total phosphorus during water year 2005 were 5,820, 180, and $752 \mathrm{lbs}$, respectively.

\section{Waiakea Stream at Hilo (16701300)}

Daily-mean loads of suspended-sediment and nutrient constituents for Waiakea Stream at Hilo for water years 2004 and 2005 are shown in figures $16 A$ and $16 B$, and tables $20 A$ and $B, 21 A$ and $B, 22 A$ and $B$, and $23 A$ and $B$. In addition, tables of daily-mean discharge are also provided (tables $24 A$, $B$, and $C$ ).

\section{Suspended Sediment}

Daily-mean loads of suspended-sediment varied from 0.00 to 468 tons/day over the period of record. Since discharge was zero for a majority of the days during the period of record, the median value of mean-daily load for suspended sediment was zero. The annual load of suspended sediment during water year 2004 was 114 tons, and the annual load during water year 2005 was 700 tons.

\section{Nutrients}

Daily-mean loads of total nitrogen, dissolved nitrite plus nitrate, and total phosphorus varied from 0.00 to $913,0.00$ to 8.5, and 0.00 to $176 \mathrm{lbs} /$ day, respectively, over the period of record. Since discharge was zero for a majority of the days during the period of record, the median value of mean-daily load for all of these constituents was zero. The annual loads for total nitrogen, dissolved nitrite plus nitrate, and total phosphorus during water year 2004 were 4,420, 82.3, and $754 \mathrm{lbs}$, respectively. The annual loads for total nitrogen, dissolved nitrite plus nitrate, and total phosphorus during water year 2005 were $1,110,19.8$, and $153 \mathrm{lbs}$, respectively.

\section{Daily-Mean Load Trends}

For the two sites on Waiakea Stream, all of the maximum daily-mean loads for the different constituents occurred in the first year of data collection, except for an estimated suspended sediment load for the lower site, which was on September 15, 2005. As mentioned before, this increase in suspended sediment load in water year 2005 was likely due to construction activities in the stream channel at the West Kawailani Road bridge, which began on September 27, 2004, and ended June 1,2005 . Only events with low discharge occurred between September 27, 2004, when construction started, and August 7 , 2005, when the suspended sediment sample was collected with higher concentration. No sampling was done for the storm of September 15-18, 2005, storm, thus the maximum is an esti- 
Table 11. Discharge, concentration and instantaneous loads of nutrients and suspended sediment for samples collected from March 14, 2004, to March 30, 2005, Waiakea Stream at Hilo (16701300), Hilo, Hawaii.

[hh:mm, hours and minutes; Conc., concentration; Load, computed from concentration value and discharge value for each sample; e, value is estimated; --, not analyzed or measured; fťs, cubic feet per second; $\mathrm{mg} / \mathrm{L}$,milligrams per liter; lbs/day, pounds per day]

\begin{tabular}{|c|c|c|c|c|c|c|c|c|c|c|c|}
\hline \multirow{2}{*}{ Date } & \multirow{2}{*}{$\begin{array}{l}\text { Mean time } \\
\text { (hh:mm) }\end{array}$} & \multirow{2}{*}{ Sample type } & \multirow{2}{*}{$\begin{array}{c}\text { Discharge, } \\
\text { instant. } \\
\left(\mathrm{ft}^{3} / \mathrm{s}\right)\end{array}$} & \multicolumn{2}{|c|}{ Total nitrogen $^{\mathrm{a}}$} & \multicolumn{2}{|c|}{$\begin{array}{l}\text { Nitrogen, nitrite + } \\
\text { nitrate, dissolved }\end{array}$} & \multicolumn{2}{|c|}{ Total phosphorus } & \multicolumn{2}{|c|}{ Suspended sediment } \\
\hline & & & & $\begin{array}{c}\text { Conc. } \\
\text { (mg/L as } \mathrm{N})\end{array}$ & $\begin{array}{c}\text { Load } \\
\text { (Ibs/day) }\end{array}$ & $\begin{array}{c}\text { Conc. } \\
\text { (mg/L as } \mathrm{N})\end{array}$ & $\begin{array}{c}\text { Load } \\
\text { (Ibs/day) }\end{array}$ & $\begin{array}{c}\text { Conc. } \\
\text { (mg/L as } \mathrm{P})\end{array}$ & $\begin{array}{c}\text { Load } \\
\text { (Ibs/day) }\end{array}$ & $\begin{array}{l}\text { Conc. } \\
\text { (mg/L) }\end{array}$ & $\begin{array}{c}\text { Load } \\
\text { (tons/day) }\end{array}$ \\
\hline March 14, 2004 & $15: 00$ & automated point sample & 362 & 1.0 & 2,000 & 0.028 & 55 & 0.174 & 340 & 57 & 56 \\
\hline March 14, 2004 & $15: 05$ & automated point sample & 362 & 0.89 & 1,700 & 0.024 & 47 & 0.169 & 330 & 47 & 46 \\
\hline March 14, 2004 & $15: 15$ & automated point sample & 362 & 0.76 & 1,500 & 0.026 & 51 & 0.138 & 269 & 47 & 46 \\
\hline March 14, 2004 & $15: 30$ & automated point sample & 367 & 0.69 & 1,400 & 0.022 & 44 & 0.112 & 222 & 34 & 34 \\
\hline March 14, 2004 & $15: 45$ & automated point sample & 337 & 0.59 & 1,100 & 0.019 & 34 & 0.096 & 174 & 29 & 26 \\
\hline March 14, 2004 & $16: 00$ & automated point sample & 318 & 0.48 & 820 & 0.018 & 31 & 0.084 & 140 & 22 & 19 \\
\hline March 15, 2004 & $12: 15$ & dip sample & 419 & 0.22 & 500 & 0.038 & 86 & 0.035 & 79 & 8 & 9 \\
\hline March 15, 2004 & $12: 16$ & automated point sample & 419 & 0.26 & 590 & 0.031 & 70 & 0.055 & 120 & 8 & 9 \\
\hline February 4, 2005 & $07: 30$ & automated point sample & 44 & 0.35 & 83 & 0.084 & 20 & 0.043 & 10 & -- & -- \\
\hline February 4, 2005 & 08:00 & automated point sample & 38 & 0.30 & 61 & 0.087 & 18 & 0.032 & 6.6 & -- & -- \\
\hline February 4, 2005 & $08: 30$ & automated point sample & 32 & 0.28 & 48 & 0.079 & 14 & 0.030 & 5.2 & -- & -- \\
\hline February 4, 2005 & 09:00 & automated point sample & 23 & 0.23 & 29 & 0.061 & 7.6 & 0.033 & 4.1 & -- & -- \\
\hline February 4, 2005 & 09:30 & automated point sample & 18 & 0.27 & 26 & 0.094 & 9.1 & 0.027 & 2.6 & -- & -- \\
\hline February 4, 2005 & $10: 00$ & automated point sample & 12 & 0.29 & 19 & 0.102 & 6.6 & 0.023 & 1.5 & -- & -- \\
\hline February 4, 2005 & $10: 30$ & automated point sample & 7.5 & 0.26 & 11 & 0.113 & 4.6 & 0.021 & 0.85 & -- & -- \\
\hline February 4, 2005 & $11: 00$ & automated point sample & 3.9 & 0.27 & 5.7 & 0.121 & 2.5 & 0.022 & 0.46 & -- & -- \\
\hline March 28, 2005 & $13: 45$ & automated point sample & 20 & 0.31 & 33 & 0.021 & 2.3 & 0.079 & 8.5 & 58 & 3.1 \\
\hline March 28, 2005 & $13: 50$ & automated point sample & 20 & $\mathrm{e} 0.26$ & e28 & $\mathrm{e} 0.014$ & $\mathrm{e} 1.5$ & 0.089 & 9.6 & 63 & 3.4 \\
\hline March 28, 2005 & $14: 00$ & automated point sample & 26 & 0.33 & 46 & 0.017 & 2.4 & 0.120 & 17 & 85 & 6.0 \\
\hline March 28, 2005 & $14: 15$ & automated point sample & 28 & 0.43 & 65 & 0.017 & 2.6 & 0.140 & 21 & 76 & 5.7 \\
\hline March 28, 2005 & $14: 30$ & automated point sample & 28 & $\mathrm{e} 0.30$ & $\mathrm{e} 45$ & $\mathrm{e} 0.014$ & e2.1 & 0.097 & 15 & 55 & 4.2 \\
\hline March 28, 2005 & $14: 45$ & automated point sample & 26 & 0.36 & 50 & 0.017 & 2.4 & 0.102 & 14 & 46 & 3.2 \\
\hline March 30, 2005 & $02: 30$ & automated point sample & 38 & 0.23 & 47 & 0.049 & 10 & 0.028 & 5.7 & 16 & 1.6 \\
\hline March 30, 2005 & $02: 35$ & automated point sample & 41 & 0.24 & 53 & 0.049 & 11 & 0.040 & 8.8 & 20 & 2.2 \\
\hline March 30, 2005 & $02: 45$ & automated point sample & 49 & 0.24 & 63 & 0.049 & 13 & 0.035 & 9.3 & 21 & 2.8 \\
\hline March 30, 2005 & 03:00 & automated point sample & 52 & 0.32 & 90 & 0.051 & 14 & 0.049 & 14 & 25 & 3.5 \\
\hline March 30, 2005 & $03: 15$ & automated point sample & 54 & 0.32 & 93 & 0.049 & 14 & 0.061 & 18 & 32 & 4.7 \\
\hline March 30, 2005 & 03:30 & automated point sample & 58 & 0.33 & 100 & 0.048 & 15 & 0.075 & 23 & 41 & 6.4 \\
\hline March 30, 2005 & $11: 54$ & automated point sample & 62 & 0.25 & 84 & 0.038 & 13 & 0.040 & 13 & -- & -- \\
\hline March 30, 2005 & $11: 57$ & discharge-weighted sample & 62 & 0.21 & 70 & 0.038 & 13 & 0.030 & 10 & -- & -- \\
\hline March 30, 2005 & $12: 00$ & automated point sample & 62 & 0.22 & 74 & 0.039 & 13 & 0.032 & 11 & -- & -- \\
\hline
\end{tabular}

a Total nitrogen is calculated by adding nitrogen, total organic + ammonia (Kjeldahl), to nitrogen, nitrite + nitrate, dissolved. If the concentration value of nitrogen, nitrite + nitrate, dissolved,

is estimated and below the minimum reporting level, the concentration value of total nitrogen is reported as the sum of the values shown for nitrogen, total organic + ammonia (Kjeldahl) and nitrogen, nitrite + nitrate, dissolved, and noted as estimated. 
Table 12. Discharge, concentration and instantaneous loads of suspended sediment, for samples collected without associated nutrient analyses, from November 9, 2005, to January 26, 2006, Alenaio Stream at Kilauea Avenue Bridge (16701650), Hilo, Hawaii.

[hh:mm, hours and minutes; Conc., concentration; Load, computed from concentration value and discharge value for each sample; $\mathrm{ft}^{3} / \mathrm{s}$, cubic feet per second; $\mathrm{mg} / \mathrm{L}$, milligrams per liter; lbs/day, pounds per day]

\begin{tabular}{|c|c|c|c|c|c|}
\hline \multirow[b]{2}{*}{ Date } & \multirow[b]{2}{*}{ Mean time (hh:mm) } & \multirow[b]{2}{*}{ Sample type } & \multirow[b]{2}{*}{$\begin{array}{l}\text { Discharge, instant. } \\
\qquad\left(\mathrm{ft}^{3} / \mathrm{s}\right)\end{array}$} & \multicolumn{2}{|c|}{ Suspended sediment } \\
\hline & & & & $\begin{array}{l}\text { Conc. } \\
\text { (mg/L) }\end{array}$ & $\begin{array}{c}\text { Load } \\
\text { (tons/day) }\end{array}$ \\
\hline November 9, 2005 & $15: 18$ & automated point sample & -- & 6 & -- \\
\hline November 9, 2005 & $16: 02$ & automated point sample & -- & 6 & -- \\
\hline November 9, 2005 & $16: 15$ & automated point sample & -- & 6 & -- \\
\hline January 26, 2006 & $14: 28$ & automated point sample & -- & 5 & -- \\
\hline
\end{tabular}

mate based on the relation between sample concentration and discharge for the August 7 sample.

Maximum daily-mean load values were not all caused by a single storm event. In some cases, some samples had lower constituent concentrations than samples from other events, but flows were higher, resulting in higher daily-mean loads.

Along Waiakea Stream, concentrations and daily-mean loads were higher at the upstream site than the lower site for a given storm in 2004 (fig. 17). However, during the storm event beginning on March 27, 2005 (fig. 18), the maximum concentrations of suspended sediment and total nitrogen were nearly equal, yet the loads were much less at the lower site due to less discharge. During the latter part of water year 2005, possibly due to the construction in the stream channel mentioned above, the suspended sediment load was higher at the lower site (fig. 19), but since no nutrient samples were collected during both the August 7 and September 15, 2005, storms, it is uncertain what affect the construction had on nutrient loads. Nutrient concentrations and loads were estimated for the storms on August 7 and September 15, 2005 at the lower site.

In general, storms that were not sampled have estimated data. The estimated loads, for storms that were not sampled, are influenced by the concentrations and loads from samples collected from preceding and/or proceeding events. During any given year of sampling, the more storms with collected samples, the more validity and confidence in these estimations. A combination of sampling thoroughly over the length of an event, with a range of event sizes, durations, and patterns to characterize the manner in which concentration varies during a storm, and, at least, a few samples collected for every peak would allow more confidence in the continuous record.

\section{Summary}

Nutrient and suspended-sediment samples were collected during wet-weather streamflow conditions at three sites in the vicinity of Hilo, Hawaii, during October 2003 to March 2006.
Two sites on Waiakea Stream, and one site on Alenaio Stream were selected to represent different land-use types in the area. Discharge was measured at the two sites on Waiakea Stream. For Alenaio Stream at Kilauea Avenue Bridge, a stage/discharge relation was not created due to hydraulic problems in the channel. Manual discharge measurements were made at the site, and a second site collected discharge data about 0.47 miles upstream of the sampling site to supplement discharge information at the lower site.

During 2003 to 2006, 267 suspended sediment samples and 136 nutrient samples were collected at the three sites. Using the analyses from the Waiakea Stream sites, continuous records of daily-mean loads were computed using a graphical technique that combines continuous discharge data with concentration data for samples collected at each sampling site. No daily-mean load record was computed for Alenaio Stream at Kilauea Avenue Bridge due to the problems with computing the discharge record at this site.

For the daily-mean load record at the two sites on Waiakea Stream, the maximum daily-mean loads occurred in 2004, except for suspended sediment load at the lower site, which reached its maximum value during the latter part of 2005. In a similar manner, the continuous record of daily-mean loads during 2004 showed higher daily-mean loads per storm event for suspended sediments and nutrients at the upstream site, Waiakea Stream at Hoaka Road, relative to the downstream site, Waiakea Stream at Hilo. During the latter part of 2005, however, the loads were higher at the downstream site than the upstream site for suspended sediment. A construction project within the stream channel during 2004-2005 may have been the source of increased suspended sediment at the lower site. 


\section{References Cited}

Edwards, T.K., and Glysson, G.D., 1999, Field methods for measurement of fluvial sediment: Techniques of Water-Resources Investigations of the U.S. Geological Survey, Book 3, Chapter C2, 89 p.

Fishman, M.J., ed., 1993, Methods of analysis by the U.S. Geological Survey National Water Quality Laboratory-Determination of inorganic and organic constituents in water and fluvial sediments: U.S. Geological Survey Open-File Report 93-125, 217 p.

Giambelluca, T.W., Nullet, M.A., and Schroeder, T.A., 1986, Rainfall Atlas of Hawaii-Hawaii Department of Land and Natural Resources Report R76, 267 p.

Giambelluca, T.W. and Schroeder, T.A., 1999, Climate, a chapter in the Atlas of Hawaii, 3rd edition; University of Hawaii press, editors: Juvik, S. P. and Juvik, J.O., pages 49-59.

Guy, H.P., 1969, Laboratory theory and methods for sediment analysis: Techniques of Water-Resources Investigations of the U.S. Geological Survey, Book 5, Chapter C1, 58 p.

Hawaii State Department of Health, Environmental Planning Office, 2004, Final 2004 List of impaired waters in Hawaii prepared under Clean Water Act 303(d): 67 p.

Hem, J.D., 1985, Study and interpretation of the chemical characteristics of natural water: U.S. Geological Survey Water-Supply Paper $2254,263 \mathrm{p}$.

Koltun, G.F., Eberle, Michael, Gray, J.R., and Glysson, G.D., 2006, User's manual for the Graphical Constituent Loading Analysis System (GCLAS): U.S. Geological Survey Techniques and Methods $4-\mathrm{C} 1,51 \mathrm{p}$.

McKallip, T.E., Koltun, G.F., Gray, J.R., and Glysson, G.D., 2001, GCLAS - a graphical constituent loading analysis system: Proceedings of the 7th Federal Interagency Sedimentation Conference, Reno, Nevada, March 25-29, Vol. II, VI-49 to VI-52.

National Oceanographic and Atmospheric Administration, 1995, NOAA Coastal Change Analysis Program (C-CAP)— Guidance for Regional Implementation, 1995: NOAA Technical Report NMFS 123 [http://www.csc.noaa.gov/crs/lca/pdf/protocol.pdf].

National Oceanographic and Atmospheric Administration, 2001, NOAA Coastal Change Analysis program (C-CAP). Hawaii Land Cover, Main Island: U.S. Department of Commerce, National Oceanographic and Atmospheric Administration, Coastal Services Center: Charleston, S.C. [http://www.csc.noaa.gov/crs/lca/hawaii. html].

National Oceanographic and Atmospheric Administration, 2006, NOAA Coastal Change Analysis program (C-CAP). Original C-CAP Classification Scheme: U.S. Department of Commerce, National Oceanographic and Atmospheric Administration, Coastal Services Center: Charleston, S.C. [http://www.csc.noaa.gov/crs/ lca/oldscheme].
Patton, C.J., and Truitt, E.P., 2000, Methods of analysis by the U.S. Geological Survey National Water Quality Laboratory-Determination of ammonium plus organic nitrogen by a Kjeldahl digestion method and an automated photometric finish that includes digest cleanup by gas diffusion: U.S. Geological Survey Open-File Report 00-170, 31 p.

Porterfield, G.P., 1972, Computation of fluvial-sediment discharge: Techniques of Water-Resources Investigations of the U.S. Geological Survey, Book 3, Chapter C3, 66 p.

Rantz, S.E., and others, 1982, Measurement and computation of streamflow: Volume 1, Measurement of stage and discharge; Volume 2, Computation of discharge: U.S. Geological Survey Water-Supply Paper 2175, 284 p. and 346 p.

Sato, H.H., Ikeda, W., Paeth, R., Smythe, R,, and Takehiro, M. Jr., 1973, Soil Survey of the Island of Hawaii, State of Hawaii-U.S. Department of Agriculture, Soil Conservation Service, 115 p., 195 sheets.

Sauer, V.B., 2002, Standards for the analysis and processing of surface-water data and information using electronic methods: U.S. Geological Survey Water-Resources Investigations Report 01-4044, 92 p.

Soil Survey Staff, 2006. Soil Survey of Hawaii County, Hawaii; U.S. Department of Agriculture Natural Resources Conservation Service [http://soildatamart.nrcs.usda.gov/Survey.aspx?State=HI", accessed 07/26/2007].

Stearns, H.T., and Macdonald, G.A., 1946, Geology and groundwater resources of the island of Hawaii-Hawaii Division of Hydrography Bulletin 9, 363 p., 3 pl.

U.S. Department of Agriculture, Soil Conservation Service, 1976, Watershed Work Plan, Wailuku-Alenaio Watershed, Hawaii County, Hawaii, prepared by Mauna Kea Soil \& Water Conservation District, Waiakea Soil \& Water District, and County of Hawaii, 55 p.

U.S. Environmental Protection Agency, 1983, EPA Method 365.1, Determination of Phosphorus by Semi-Automated Colorimetry Revision 2.0, Methods for the Determination of Inorganic Substances in Environmental Samples, in Methods for chemical analysis of water and wastewater: EPA-600/4-79-020, USEPA, Cincinnati, Ohio.

Wilde, F.D., Radtke, D.B., Gibs, Jacob, and Iwatsubo, R.T., eds., 1998, National field manual for the collection of water-quality data: U.S. Geological Survey Techniques of Water-Resources Investigations, Book 9 (variable pagination).

Wolfe, E.W. and Morris, J, 1996, Geological Map of the Island of Hawaii, U.S. Geological Survey Miscellaneous Investigations Series, Map 12524A, 3 sheets. 
Figures 15 through 19 and tables 13 through 24 
$\boldsymbol{A}$
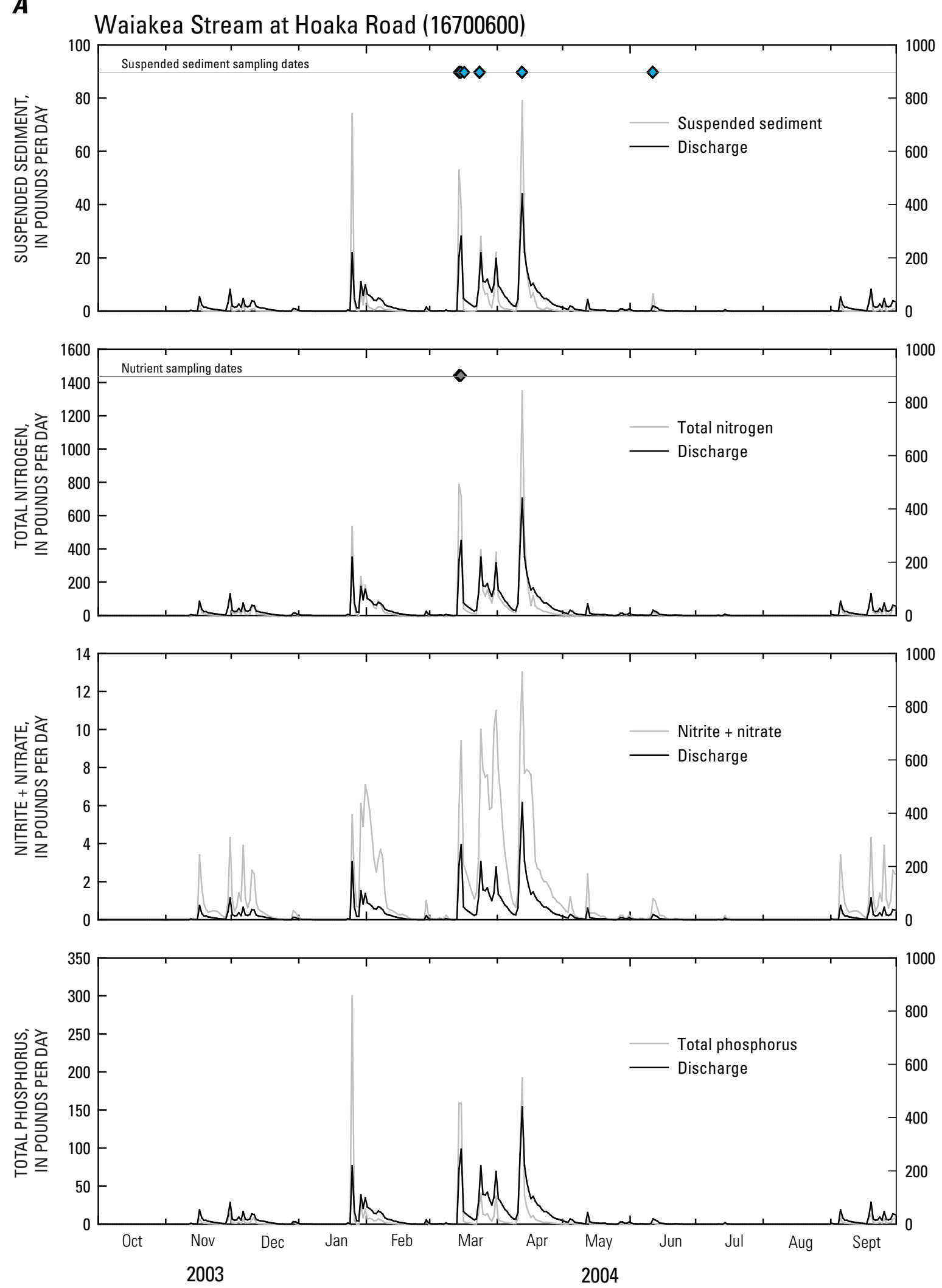

Figure 15. Daily-mean loads of suspended sediment and nutrients at Waiakea Stream at Hoaka Road (16700600), Hilo, Hawaii: (A) October 1, 2003, to September 30, 2004, (B) October 1, 2004, to September 30, 2005. 
$\boldsymbol{B}$
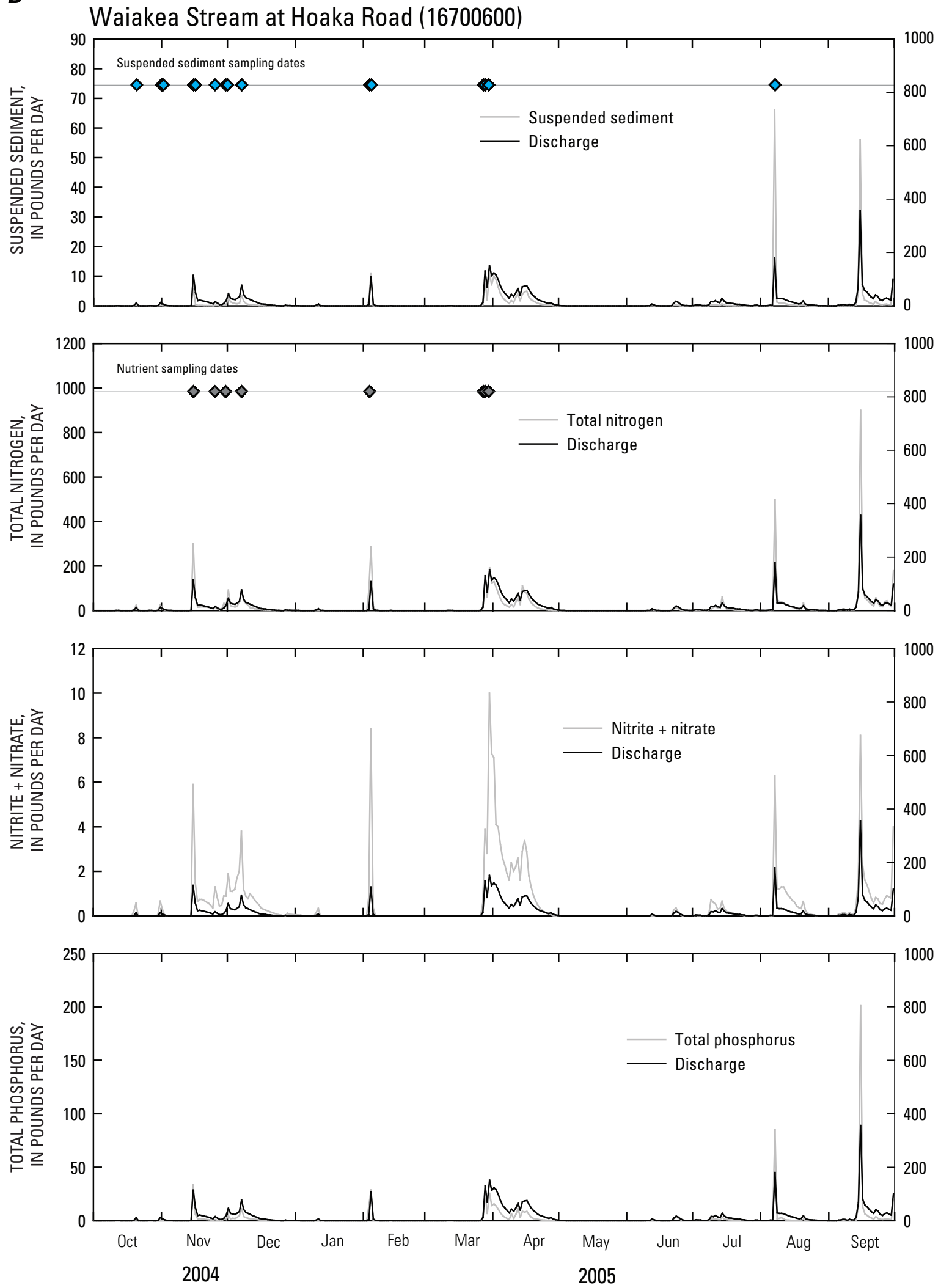

Figure 15. Daily-mean loads of suspended sediment and nutrients at Waiakea Stream at Hoaka Road (16700600), Hilo, Hawaii: (A) October 1, 2003, to September 30, 2004, (B) October 1, 2004, to September 30, 2005.—Continued. 
$\boldsymbol{A}$
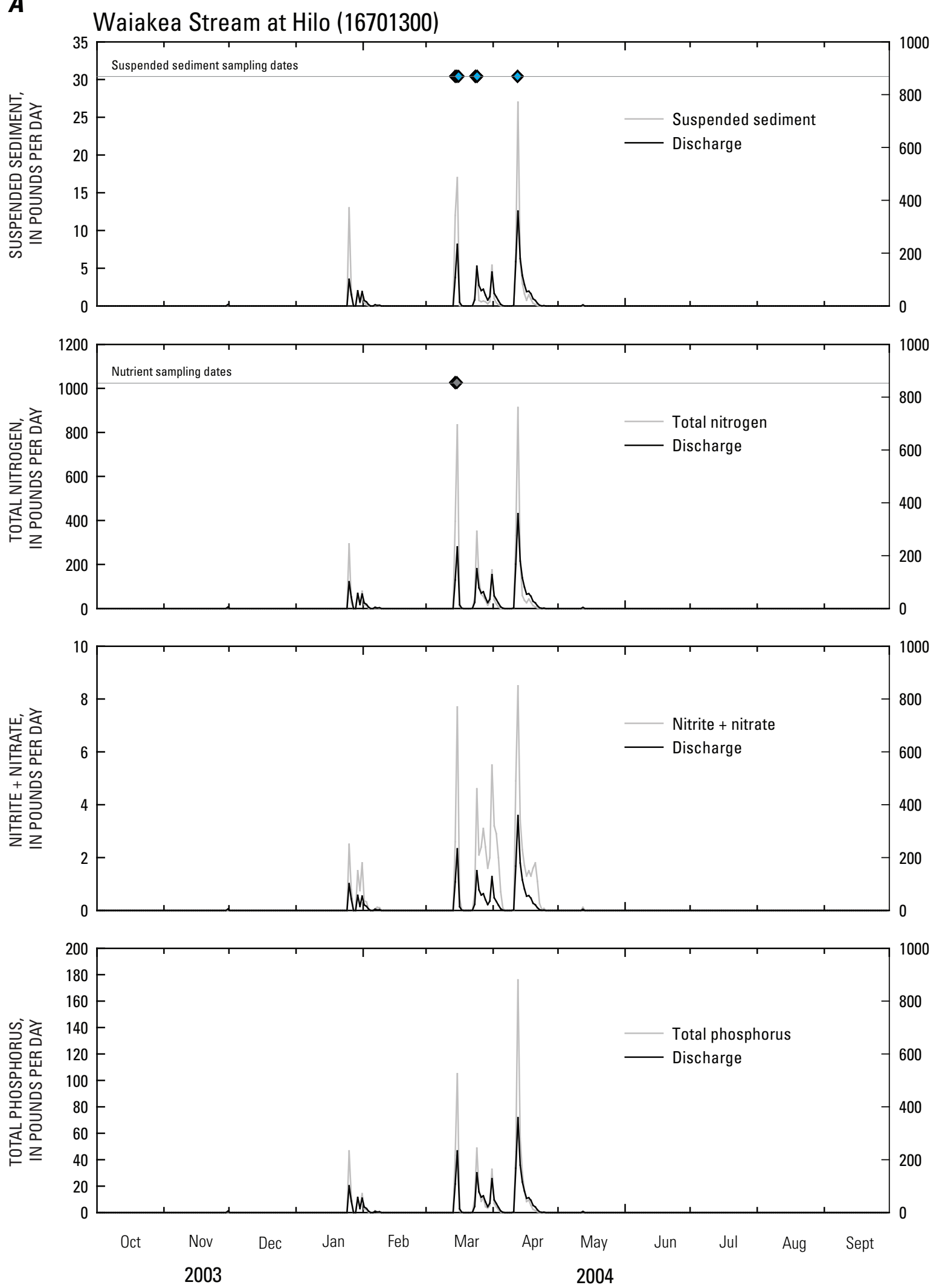

Figure 16. Daily-mean loads of suspended sediment and nutrients at Waiakea Stream at Hilo (16701300), Hilo, Hawaii: $(A)$ October 1, 2003, to September 30, 2004, (B) October 1, 2004 to September 30, 2005. 
$B$
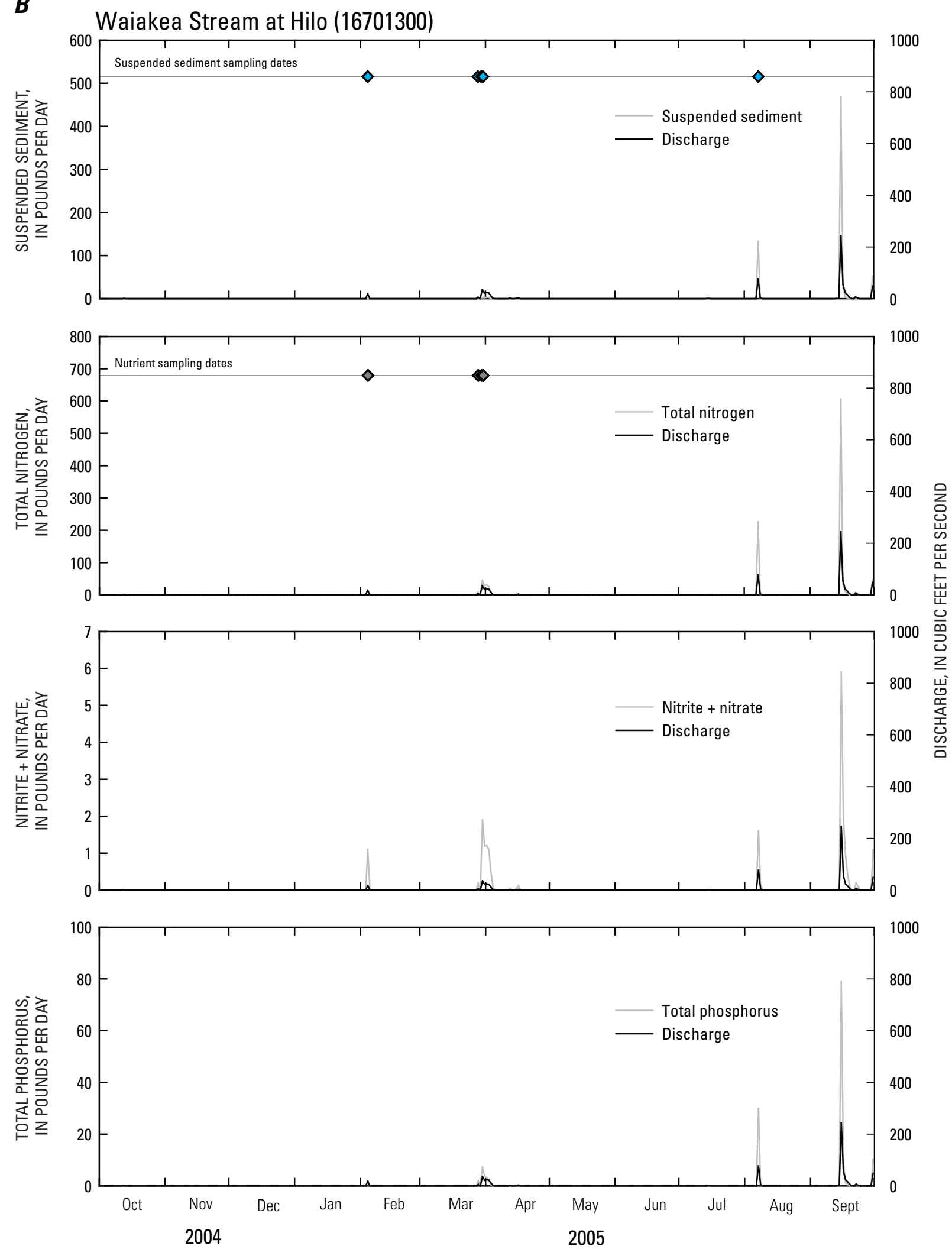

Figure 16. Daily-mean loads of suspended sediment and nutrients at Waiakea Stream at Hilo (16701300), Hilo, Hawaii: (A) October 1, 2003, to September 30, 2004, (B) October 1, 2004, to September 30, 2005.—Continued. 

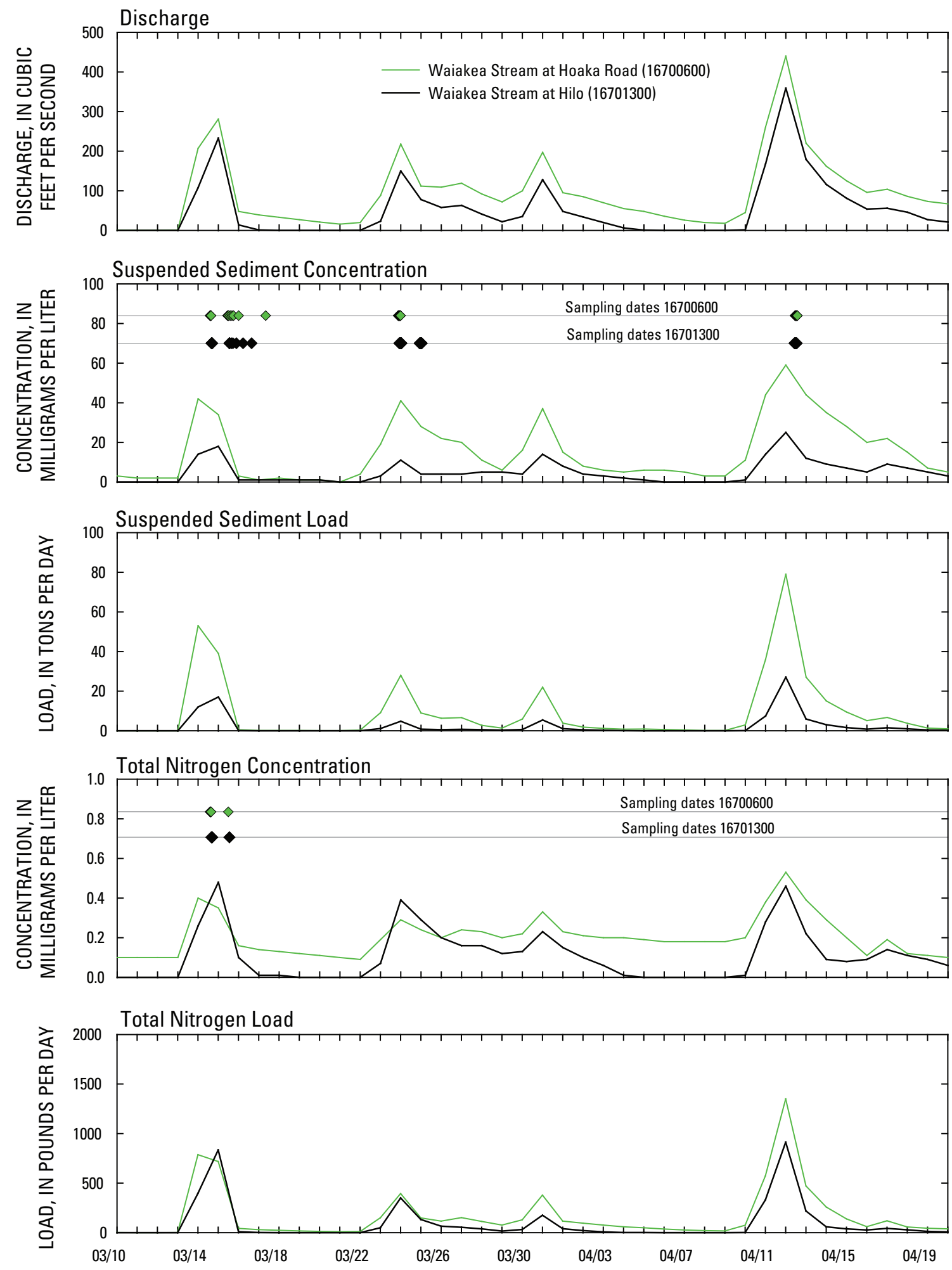

Figure 17. Daily-mean concentration and load for suspended sediment and total nitrogen, and dailymean discharge, for sites Waiakea Stream at Hoaka Road (16700600) and Waiakea Stream at Hilo (16701300) during early March 2004, Hilo, Hawaii. 

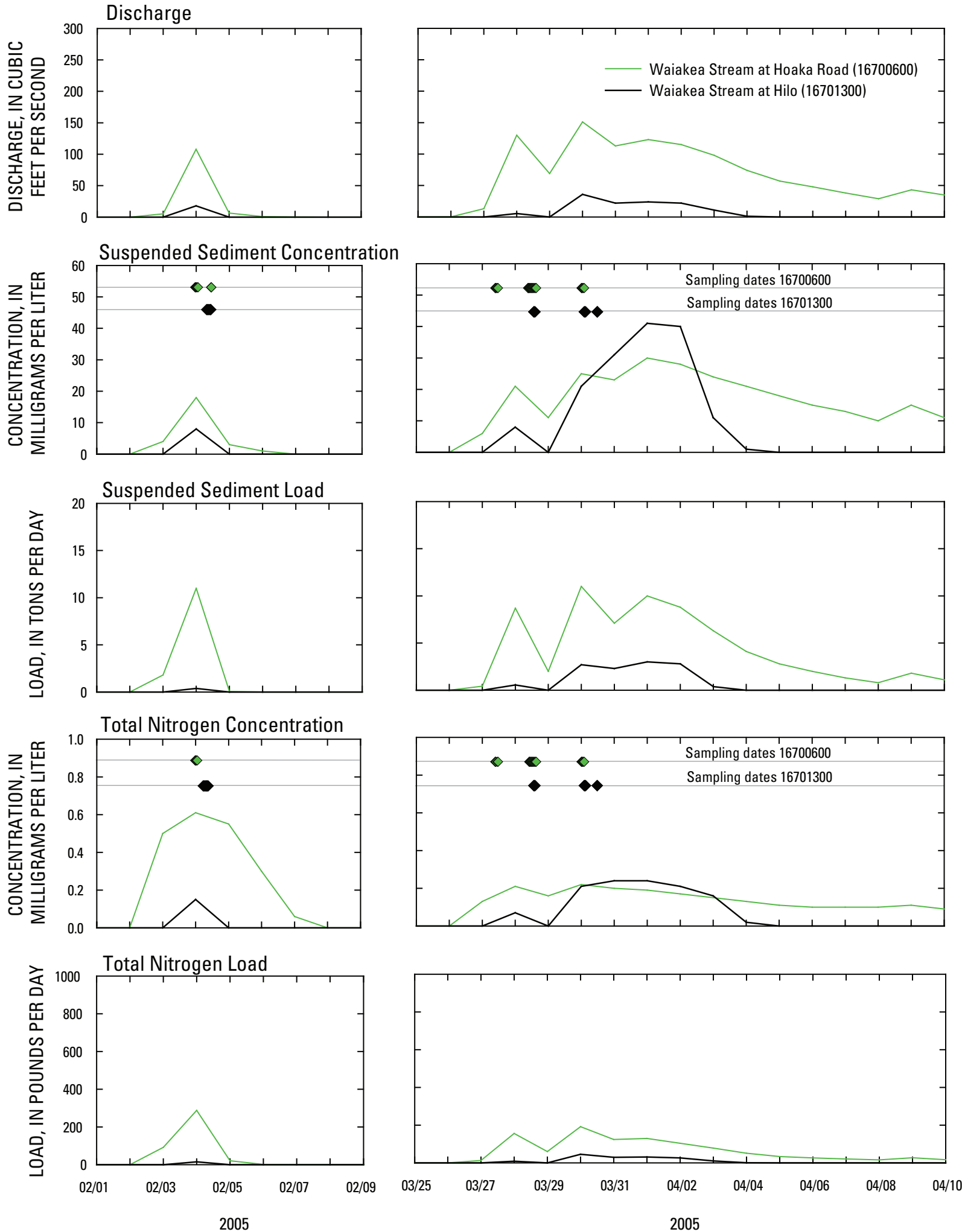

Figure 18. Daily-mean concentration and load for suspended sediment and total nitrogen, and daily-mean discharge, for sites Waiakea Stream at Hoaka Road (16700600) and Waiakea Stream at Hilo (16701300) during early February and late March 2005, Hilo, Hawaii. 

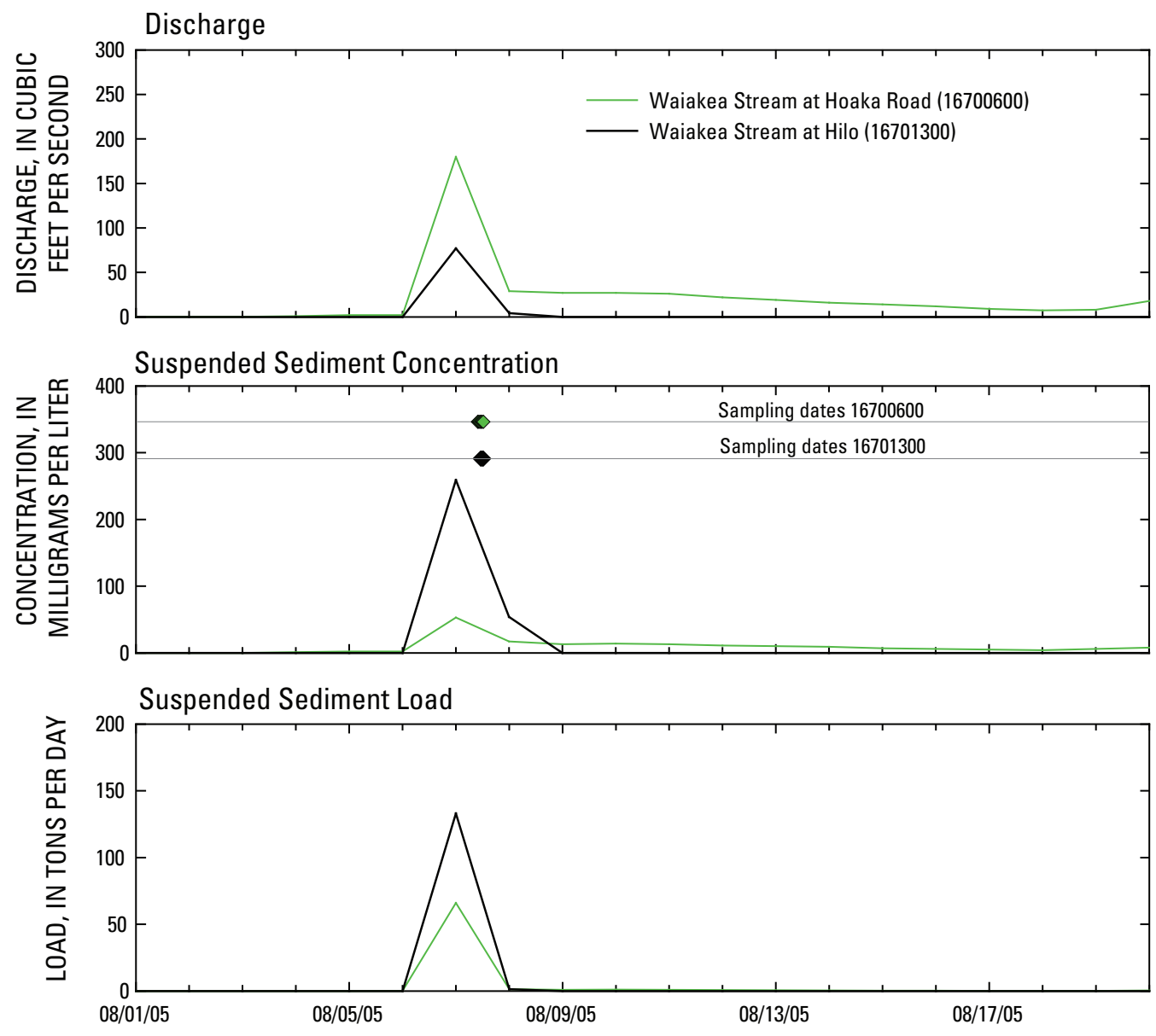

Figure 19. Daily-mean concentration and load for suspended sediment, and daily-mean discharge, for sites Waiakea Stream at Hoaka Road (16700600) and Waiakea Stream at Hilo (16701300) during early August, 2005 Hilo, Hawaii. 
Table 13. Discharge, concentration and instantaneous loads of nutrients and suspended sediment for samples collected from November 9 , 2005, to March 9, 2006, Alenaio Stream at Kilauea Avenue Bridge (16701650), Hilo, Hawaii.

[hh:mm, hours and minutes; Conc., concentration; Load, computed from concentration value and discharge value for each sample; e, value is estimated; --, not analyzed or measured; $\mathrm{ft}^{3} / \mathrm{s}$, cubic feet per second; mg/L,milligrams per liter; lbs/day, pounds per day]

\begin{tabular}{|c|c|c|c|c|c|c|c|c|c|c|c|}
\hline \multirow{2}{*}{ Date } & \multirow{2}{*}{$\begin{array}{c}\text { Mean time } \\
\text { (hh:mm) }\end{array}$} & \multirow{2}{*}{ Sample type } & \multirow{2}{*}{$\begin{array}{c}\text { Discharge, } \\
\text { instant. }^{\mathrm{a}} \\
\left(\mathrm{ft}^{3} / \mathrm{s}\right)\end{array}$} & \multicolumn{2}{|c|}{ Total nitrogen ${ }^{b}$} & \multicolumn{2}{|c|}{$\begin{array}{l}\text { Nitrogen, nitrite + } \\
\text { nitrate, dissolved }\end{array}$} & \multicolumn{2}{|c|}{ Total phosphorus } & \multicolumn{2}{|c|}{ Suspended sediment } \\
\hline & & & & $\begin{array}{c}\text { Conc. } \\
\text { (mg/L as } \mathrm{N})\end{array}$ & $\begin{array}{c}\text { Load } \\
\text { (Ibs/day) }\end{array}$ & $\begin{array}{c}\text { Conc. } \\
\text { (mg/L as } \mathrm{N} \text { ) }\end{array}$ & $\begin{array}{c}\text { Load } \\
\text { (Ibs/day) }\end{array}$ & $\begin{array}{c}\text { Conc. } \\
\text { (mg/L as } \mathrm{P})\end{array}$ & $\begin{array}{c}\text { Load } \\
\text { (Ibs/day) }\end{array}$ & $\begin{array}{l}\text { Conc. } \\
\text { (mg/L) }\end{array}$ & $\begin{array}{c}\text { Load } \\
\text { (tons/day) }\end{array}$ \\
\hline November 9, 2005 & $13: 32$ & automated point sample & 42.6 & 0.66 & 150 & 0.075 & 17 & 0.063 & 14 & 9 & 1 \\
\hline November 9, 2005 & $13: 46$ & automated point sample & 42.9 & 0.28 & 65 & 0.075 & 17 & 0.022 & 5.1 & 7 & 0.8 \\
\hline November 9, 2005 & $15: 17$ & automated point sample & 32.8 & 0.27 & 48 & 0.074 & 13 & 0.019 & 3.4 & -- & -- \\
\hline November 9, 2005 & $15: 27$ & automated point sample & 32.8 & 0.24 & 42 & 0.073 & 13 & 0.018 & 3.2 & -- & -- \\
\hline November 9, 2005 & $16: 00$ & automated point sample & -- & 0.26 & -- & 0.071 & -- & 0.019 & -- & -- & -- \\
\hline November 9, 2005 & $16: 10$ & discharge-weighted sample & -- & 0.25 & -- & 0.088 & -- & 0.018 & -- & 9 & -- \\
\hline November 9, 2005 & $16: 14$ & automated point sample & -- & 0.25 & -- & 0.070 & -- & 0.018 & -- & -- & -- \\
\hline January 26, 2006 & $09: 45$ & automated point sample & -- & $\mathrm{e} 0.50$ & -- & $\mathrm{e} 0.011$ & -- & 0.096 & -- & 182 & -- \\
\hline January 26, 2006 & $10: 00$ & automated point sample & -- & 0.62 & -- & 0.025 & -- & 0.100 & -- & 113 & -- \\
\hline January 26, 2006 & $10: 15$ & automated point sample & -- & 0.54 & -- & 0.020 & -- & 0.188 & -- & 67 & -- \\
\hline January 26, 2006 & $10: 30$ & automated point sample & -- & 0.50 & -- & 0.024 & -- & 0.145 & -- & 58 & -- \\
\hline January 26, 2006 & 11:00 & automated point sample & -- & 0.35 & -- & 0.023 & -- & 0.103 & -- & 56 & -- \\
\hline January 26, 2006 & 13:08 & automated point sample & -- & 0.36 & -- & 0.069 & -- & 0.064 & -- & -- & -- \\
\hline January 26, 2006 & 13:09 & discharge-weighted sample & -- & 0.47 & -- & 0.073 & -- & 0.043 & -- & -- & -- \\
\hline January 26, 2006 & $14: 26$ & automated point sample & -- & 0.31 & -- & 0.097 & -- & 0.097 & -- & -- & -- \\
\hline January 26, 2006 & $14: 27$ & discharge-weighted sample & -- & 0.28 & -- & 0.097 & -- & 0.020 & -- & -- & -- \\
\hline January 26, 2006 & $16: 00$ & automated point sample & -- & 0.36 & -- & 0.099 & -- & 0.015 & -- & 12 & -- \\
\hline January 26, 2006 & $16: 15$ & automated point sample & 371 & 0.43 & 860 & 0.097 & 190 & 0.043 & 86 & 23 & 23 \\
\hline January 26, 2006 & $16: 30$ & automated point sample & 371 & 0.56 & 1,100 & 0.100 & 200 & 0.066 & 130 & 48 & 48 \\
\hline January 26, 2006 & $16: 45$ & automated point sample & -- & 0.66 & -- & 0.099 & -- & 0.036 & -- & 53 & -- \\
\hline January 26, 2006 & $17: 00$ & automated point sample & -- & 0.59 & -- & 0.092 & -- & 0.064 & -- & 50 & -- \\
\hline January 26, 2006 & $17: 15$ & automated point sample & -- & 0.60 & -- & 0.077 & -- & 0.078 & -- & 45 & -- \\
\hline March 9, 2006 & $07: 15$ & automated point sample & -- & 0.70 & -- & 0.085 & -- & 0.184 & -- & 95 & -- \\
\hline March 9, 2006 & $07: 30$ & automated point sample & -- & 0.76 & -- & 0.085 & -- & 0.174 & -- & 96 & -- \\
\hline March 9, 2006 & $07: 45$ & automated point sample & -- & 0.83 & -- & 0.086 & -- & 0.194 & -- & 101 & -- \\
\hline March 9, 2006 & 08:00 & automated point sample & -- & 0.84 & -- & 0.086 & -- & 0.192 & -- & 90 & -- \\
\hline March 9, 2006 & $08: 15$ & automated point sample & -- & 0.75 & -- & 0.084 & -- & 0.154 & -- & 108 & -- \\
\hline March 9, 2006 & $08: 30$ & automated point sample & -- & 0.70 & -- & 0.084 & -- & 0.160 & -- & 88 & -- \\
\hline March 9, 2006 & $14: 15$ & automated point sample & 494 & 0.32 & 850 & 0.132 & 352 & 0.028 & 75 & 15 & 20 \\
\hline March 9, 2006 & $14: 30$ & automated point sample & 581 & 0.32 & 1,000 & 0.135 & 423 & 0.025 & 78 & 14 & 22 \\
\hline March 9, 2006 & $14: 45$ & automated point sample & 615 & 0.32 & 1,100 & 0.136 & 451 & 0.028 & 93 & 14 & 23 \\
\hline March 9, 2006 & $15: 00$ & automated point sample & 493 & 0.31 & 820 & 0.138 & 367 & 0.023 & 61 & 14 & 19 \\
\hline March 9, 2006 & $15: 15$ & automated point sample & 448 & 0.29 & 700 & 0.141 & 341 & 0.027 & 65 & 13 & 16 \\
\hline March 9, 2006 & $15: 30$ & automated point sample & 550 & 0.28 & 830 & 0.141 & 418 & 0.021 & 62 & 14 & 21 \\
\hline
\end{tabular}

${ }^{a}$ Discharge measurements at this site were made by using a previously determined cross-section geometry, depth measurements, and a radar gun to estimate surface velocity

b Total nitrogen is calculated by adding nitrogen, total organic + ammonia (Kjeldahl), to nitrogen, nitrite + nitrate, dissolved. If the concentration value of nitrogen, nitrite + nitrate, dissolved, is estimated and below the minimum reporting level, the concentration value of total nitrogen is reported as the sum of the values shown for nitrogen, total organic + ammonia (Kjeldahl) and nitrogen, nitrite + nitrate, dissolved, and noted as estimated. 
Table 14. Statistical summary of discharge, suspended sediment and nutrient concentrations, and instaneous loads, for Waiakea Stream at Hoaka Road, Waiakea Stream at Hilo, and Alenaio Stream at Kilauea Avenue Bridge, Hilo, Hawaii.

[ft $\mathrm{ft}^{3} \mathrm{~s}$, cubic feet per second; $\mathrm{mg} / \mathrm{L}$, milligrams per liter; lbs/day, pounds per day]

\begin{tabular}{|c|c|c|c|c|c|}
\hline Parameter & $\begin{array}{l}\text { Number of } \\
\text { samples }\end{array}$ & Maximum & $\begin{array}{c}\text { Associated } \\
\text { discharge for } \\
\text { maximum } \\
\text { concentration or load }\end{array}$ & Minimum & $\begin{array}{c}\text { Associated } \\
\text { discharge for } \\
\text { minimum } \\
\text { concentration or } \\
\text { load }\end{array}$ \\
\hline \multicolumn{6}{|c|}{ Waiakea Stream at Hoaka Road (16700600) } \\
\hline Discharge $\left(\mathrm{ft}^{3} / \mathrm{s}\right)$ (for suspended sediment samples only) & 155 & 1,000 & -- & 2.9 & -- \\
\hline Discharge (ft3/s) (for nutrient samples only) & 71 & 684 & -- & 2.9 & -- \\
\hline Total nitrogen $(\mathrm{mg} / \mathrm{L})$ & 70 & 29 & 47 & 0.14 & 19 \\
\hline Inst. load, total nitrogen (lbs/day) & 70 & 7,400 & 47 & 5.3 & 2.9 \\
\hline Total phosphorus (mg/L) & 71 & 3.12 & 47 & 0.006 & 25 \\
\hline Inst. load, total phosphorus (lbs/day) & 71 & 850 & 115 & 0.23 & 2.9 \\
\hline
\end{tabular}

\begin{tabular}{|c|c|c|c|c|c|}
\hline \multicolumn{6}{|c|}{ Waiakea Stream at Hilo (16701300) } \\
\hline Discharge $\left(\mathrm{ft}^{3} / \mathrm{s}\right)$ (for suspended sediment samples only) & 77 & 545 & -- & 5.6 & -- \\
\hline Suspended sediment $(\mathrm{mg} / \mathrm{L})$ & 77 & 1,430 & 262 & 1 & 11 \\
\hline Discharge ( $\left.\mathrm{ft}^{3} / \mathrm{s}\right)$ (for nutrient samples only) & 31 & 419 & -- & 3.9 & -- \\
\hline Inst. load, total nitrogen (lbs/day) & 31 & 2,000 & 362 & 5.7 & 3.9 \\
\hline Nitrogen, nitrite + nitrate, dissolved $(\mathrm{mg} / \mathrm{L})$ & 31 & 0.121 & 3.9 & 0.014 & 20 \\
\hline Inst. load, nitrogen, nitrite + nitrate, dissolved (lbs/day) & $\begin{array}{l}31 \\
31\end{array}$ & $86^{* *}$ & 419 & 1.5 & 20 \\
\hline Total phosphorus (mg/L) & 31 & 0.174 & 362 & 0.021 & 7.5 \\
\hline
\end{tabular}

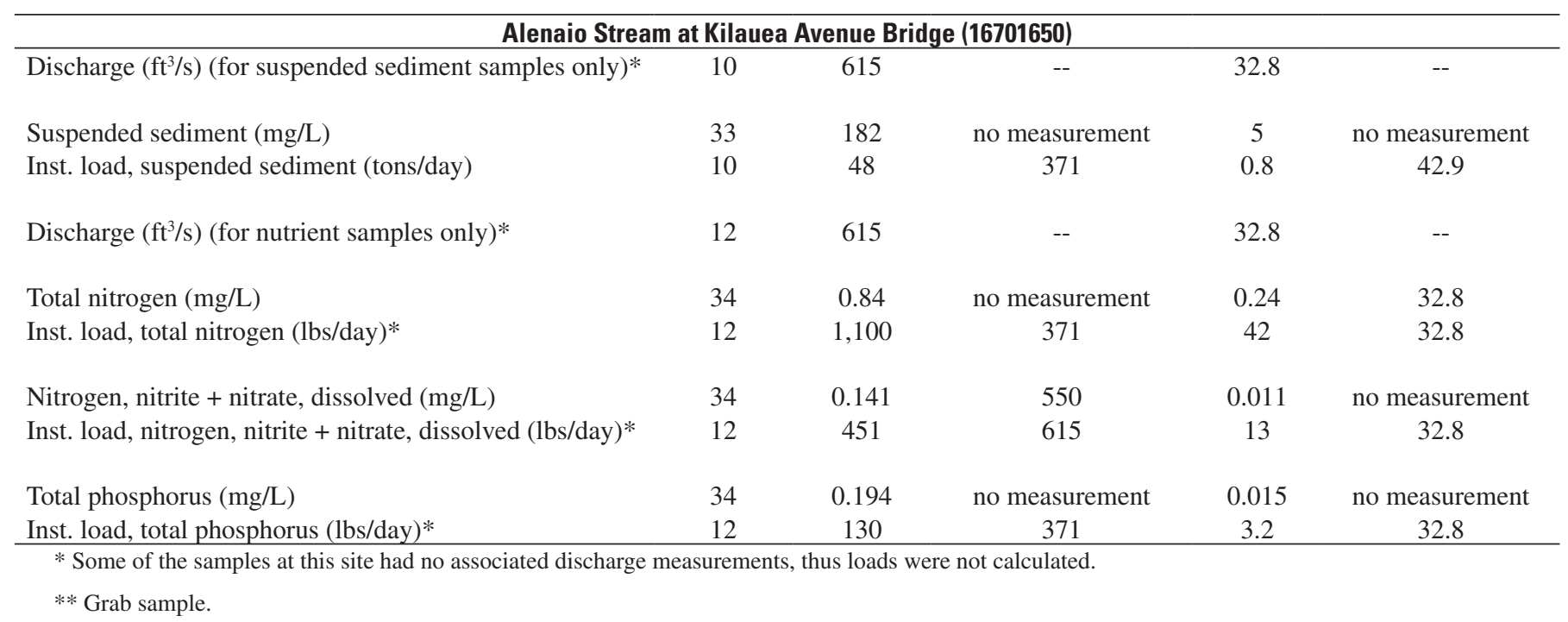


Table 15A. Daily-mean loads of suspended sediment during October 1, 2003, to September 30, 2004, Waiakea Stream at Hoaka Road (16700600), Hilo, Hawaii.

\section{STATION NUMBER 16700600 Waiakea Stream at Hoaka Road, Hawaii LATITUDE 193940 LONGITUDE 1550720 NAD83 \\ Suspended sediment discharge, tons per day WATER YEAR OCTOBER 2003 TO SEPTEMBER 2004 DAILY MEAN VALUES}

\begin{tabular}{|c|c|c|c|c|c|c|c|c|c|c|c|c|}
\hline DAY & OCT & NOV & $\mathrm{DEC}$ & JAN & FEB & MAR & APR & MAY & JUN & JUL & AUG & SEP \\
\hline 1 & e 0.00 & $\mathrm{e} 0.00$ & e0.17 & e0.00 & e2. 3 & e0.00 & e3. 8 & e0.09 & e0.02 & $\mathrm{e} 0.00$ & e0.00 & $\mathrm{e} 0.00$ \\
\hline 2 & e 0.00 & e0.00 & $\mathrm{e} 0.14$ & e0.00 & e1.2 & e0.00 & e1. 8 & $\mathrm{e} 0.06$ & e0.00 & e0.00 & e0.00 & $\mathrm{e} 0.00$ \\
\hline 3 & $\mathrm{e} 0.00$ & $\mathrm{e} 0.00$ & $\mathrm{e} 0.25$ & $\mathrm{e} 0.00$ & e0.97 & $\mathrm{e} 0.00$ & e1. 2 & $\mathrm{e} 0.04$ & $\mathrm{e} 0.00$ & $\mathrm{e} 0.00$ & $\mathrm{e} 0.00$ & $\mathrm{e} 0.00$ \\
\hline 4 & e0.00 & $\mathrm{e} 0.00$ & e0.56 & e0.00 & e0. 40 & $\mathrm{e} 0.00$ & e0.75 & e0.38 & $\mathrm{e} 0.00$ & $\mathrm{e} 0.00$ & e0.00 & $\mathrm{e} 0.00$ \\
\hline 5 & e 0.00 & $\mathrm{e} 0.00$ & $\mathrm{e} 0.12$ & e0.00 & e0.89 & e0.01 & e0.81 & $\mathrm{e} 0.24$ & e0.00 & e0.00 & e0.00 & $\mathrm{e} 0.00$ \\
\hline 6 & $\mathrm{e} 0.00$ & $\mathrm{e} 0.00$ & $\mathrm{e} 2.5$ & $\mathrm{e} 0.00$ & e1. 5 & $\mathrm{e} 0.00$ & e0.57 & $\mathrm{e} 0.10$ & $\mathrm{e} 0.00$ & $\mathrm{e} 0.00$ & $\mathrm{e} 0.00$ & $\mathrm{e} 0.00$ \\
\hline 7 & e 0.00 & $\mathrm{e} 0.00$ & e0.16 & e0.00 & e1. 6 & e 0.00 & e 0.35 & e0.06 & e 0.00 & e0.00 & e 0.00 & $\mathrm{e} 0.00$ \\
\hline 8 & $\mathrm{e} 0.00$ & $\mathrm{e} 0.00$ & $\mathrm{e} 0.12$ & $\mathrm{e} 0.00$ & e0.94 & e0.04 & e 0.15 & $\mathrm{e} 0.04$ & $\mathrm{e} 0.00$ & $\mathrm{e} 0.00$ & $\mathrm{e} 0.00$ & $\mathrm{e} 0.00$ \\
\hline 9 & e 0.00 & e0.00 & $\mathrm{e} 0.20$ & e0.00 & e0.49 & e0.00 & e0.15 & e0.02 & $\mathrm{e} 0.00$ & $\mathrm{e} 0.00$ & e0.00 & $\mathrm{e} 0.00$ \\
\hline 10 & e0.00 & $\mathrm{e} 0.00$ & $\mathrm{e} 0.72$ & e0.00 & e0.36 & e0.00 & e2.9 & e0.01 & $\mathrm{e} 0.00$ & $\mathrm{e} 0.00$ & $\mathrm{e} 0.00$ & $\mathrm{e} 0.00$ \\
\hline 11 & e 0.00 & e0.00 & e0.94 & e0.00 & e0.29 & e0.00 & e36 & $\mathrm{e} 0.00$ & e6. 4 & $\mathrm{e} 0.00$ & $\mathrm{e} 0.00$ & $\mathrm{e} 0.00$ \\
\hline 12 & $\mathrm{e} 0.00$ & $\mathrm{e} 0.00$ & $\mathrm{e} 0.17$ & $\mathrm{e} 0.00$ & $\mathrm{e} 0.24$ & $\mathrm{e} 0.00$ & e79 & e2. 4 & e0.31 & $\mathrm{e} 0.00$ & $\mathrm{e} 0.00$ & $\mathrm{e} 0.00$ \\
\hline 13 & e 0.00 & $\mathrm{e} 0.00$ & $\mathrm{e} 0.13$ & e0.00 & e0.18 & $\mathrm{e} 0.00$ & e27 & $\mathrm{e} 0.13$ & e 0.17 & $\mathrm{e} 0.00$ & $\mathrm{e} 0.00$ & $\mathrm{e} 0.00$ \\
\hline 14 & e 0.00 & $\mathrm{e} 0.00$ & e0.10 & e 0.00 & e 0.13 & e53 & e15 & $\mathrm{e} 0.07$ & $\mathrm{e} 0.04$ & $\mathrm{e} 0.24$ & $\mathrm{e} 0.00$ & $\mathrm{e} 0.00$ \\
\hline 15 & $\mathrm{e} 0.00$ & $\mathrm{e} 0.00$ & $e 0.08$ & $\mathrm{e} 0.00$ & e0.09 & e39 & e9. 4 & e0.05 & $e 0.03$ & $\mathrm{e} 0.00$ & $e 0.00$ & $\mathrm{e} 0.00$ \\
\hline 16 & $\mathrm{e} 0.00$ & e2. 5 & $\mathrm{e} 0.06$ & $\mathrm{e} 0.00$ & $\mathrm{e} 0.06$ & e 0.41 & e5. 1 & $\mathrm{e} 0.04$ & $\mathrm{e} 0.02$ & $\mathrm{e} 0.00$ & $\mathrm{e} 0.00$ & $\mathrm{e} 0.00$ \\
\hline 17 & e0.00 & $\mathrm{e} 0.22$ & $\mathrm{e} 0.04$ & $\mathrm{e} 0.00$ & $\mathrm{e} 0.04$ & $\mathrm{e} 0.12$ & e6. 7 & $e 0.03$ & $\mathrm{e} 0.00$ & $\mathrm{e} 0.00$ & $\mathrm{e} 0.00$ & $\mathrm{e} 0.00$ \\
\hline 18 & e0.00 & e0.08 & $\mathrm{e} 0.03$ & $\mathrm{e} 0.00$ & e0.03 & e0.15 & e3. 7 & $\mathrm{e} 0.02$ & e0.00 & $\mathrm{e} 0.00$ & e0.00 & $\mathrm{e} 0.00$ \\
\hline 19 & e0.00 & e0.10 & e0.02 & e0.00 & e0.01 & e0.09 & e1.3 & $\mathrm{e} 0.02$ & $\mathrm{e} 0.00$ & $\mathrm{e} 0.00$ & $\mathrm{e} 0.00$ & $\mathrm{e} 0.00$ \\
\hline 20 & e 0.00 & e0 0.02 & e 0.01 & e0.00 & e0.00 & e0.04 & e0.96 & e0.01 & $e 0.00$ & $e 0.00$ & e 0.00 & $\mathrm{e} 0.00$ \\
\hline 21 & $\mathrm{e} 0.00$ & $\mathrm{e} 0.00$ & $\mathrm{e} 0.00$ & $\mathrm{e} 0.00$ & $\mathrm{e} 0.00$ & $\mathrm{e} 0.01$ & e0.57 & $\mathrm{e} 0.00$ & $\mathrm{e} 0.00$ & $\mathrm{e} 0.00$ & $\mathrm{e} 0.00$ & $\mathrm{e} 0.00$ \\
\hline 22 & $\mathrm{e} 0.00$ & $\mathrm{e} 0.00$ & $\mathrm{e} 0.00$ & $\mathrm{e} 0.00$ & $\mathrm{e} 0.00$ & e0.28 & e0.53 & $\mathrm{e} 0.00$ & $\mathrm{e} 0.00$ & $\mathrm{e} 0.00$ & $\mathrm{e} 0.00$ & $\mathrm{e} 0.00$ \\
\hline 23 & e0.00 & e0.00 & e0.00 & e0.05 & e0.00 & e9.1 & el.1 & $\mathrm{e} 0.00$ & $\mathrm{e} 0.00$ & $\mathrm{e} 0.00$ & e0.00 & $\mathrm{e} 0.00$ \\
\hline 24 & e0.00 & e0.00 & e0.00 & e0.01 & e0.00 & e28 & e0.97 & $\mathrm{e} 0.00$ & e0.00 & $\mathrm{e} 0.00$ & e0.00 & $\mathrm{e} 0.00$ \\
\hline 25 & $\mathrm{e} 0.00$ & $\mathrm{e} 0.00$ & $\mathrm{e} 0.00$ & e74 & $\mathrm{e} 0.00$ & e8.9 & e0.65 & $\mathrm{e} 0.00$ & $\mathrm{e} 0.00$ & $\mathrm{e} 0.00$ & e 0.00 & $\mathrm{e} 0.00$ \\
\hline 26 & $\mathrm{e} 0.00$ & $\mathrm{e} 0.00$ & $\mathrm{e} 0.00$ & e3.1 & $\mathrm{e} 0.00$ & e6. 3 & $\mathrm{e} 0.33$ & $\mathrm{e} 0.00$ & $\mathrm{e} 0.00$ & $\mathrm{e} 0.00$ & $\mathrm{e} 0.00$ & $\mathrm{e} 0.00$ \\
\hline 27 & e 0.00 & e0.00 & $\mathrm{e} 0.00$ & e0.34 & e0.00 & e6. 6 & e0.25 & $\mathrm{e} 0.06$ & e0.00 & e0.00 & e0.00 & $\mathrm{e} 0.00$ \\
\hline 28 & e0.00 & $e 0.00$ & $\mathrm{e} 0.00$ & e0.15 & e0.25 & e2.7 & $\mathrm{e} 0.20$ & $\mathrm{e} 0.07$ & $\mathrm{e} 0.00$ & $\mathrm{e} 0.00$ & $\mathrm{e} 0.00$ & $\mathrm{e} 0.00$ \\
\hline 29 & e 0.00 & e2. 7 & e0.07 & e6. 8 & e0.04 & e1.3 & e 0.16 & e0.02 & e0.00 & $\mathrm{e} 0.00$ & e0.00 & $\mathrm{e} 0.00$ \\
\hline 30 & e0.00 & e6. 0 & e0.03 & e2. 4 & --- & e5. 9 & e 0.12 & $\mathrm{e} 0.00$ & $\mathrm{e} 0.00$ & $\mathrm{e} 0.00$ & e0.00 & $\mathrm{e} 0.00$ \\
\hline 31 & $\mathrm{e} 0.00$ & --- & $\mathrm{e} 0.01$ & e7.7 & --- & e22 & --- & e0.08 & --- & $\mathrm{e} 0.00$ & $\mathrm{e} 0.00$ & --- \\
\hline TOTAL & 0.00 & 11.62 & 6.63 & 94.55 & 12.01 & 183.95 & 201.52 & 4.04 & 6.99 & 0.24 & 0.00 & 0.00 \\
\hline MAX & 0.00 & 6.0 & 2.5 & 74 & 2.3 & 53 & 79 & 2.4 & 6.4 & 0.24 & 0.00 & 0.00 \\
\hline MIN & 0.00 & 0.00 & 0.00 & 0.00 & 0.00 & 0.00 & 0.12 & 0.00 & 0.00 & 0.00 & 0.00 & 0.00 \\
\hline TOTAL Q & 0.00 & 265.77 & 371.41 & 564.37 & 526.08 & 1808.74 & 2454 & 192.44 & 67.04 & 6.33 & 0.04 & 0.00 \\
\hline WTR YR & 2004 & TOTAL 521.55 & 5 MEAN & $1.4 \quad$ MAX & 79 MIN & $0.00 \quad$ MED & 0.00 & & & & & \\
\hline
\end{tabular}


Table 15B. Daily-mean loads of suspended sediment during October 1, 2004, to September 30, 2005, Waiakea Stream at Hoaka Road (16700600), Hilo, Hawaii.

\section{STATION NUMBER 16700600 Waiakea Stream at Hoaka Road, Hawaii LATITUDE 193940 LONGITUDE 1550720 NAD83 \\ Suspended sediment discharge, tons per day WATER YEAR OCTOBER 2004 TO SEPTEMBER 2005 \\ DAILY MEAN VALUES}

\begin{tabular}{|c|c|c|c|c|c|c|c|c|c|c|c|c|}
\hline DAY & $\mathrm{OCT}$ & NOV & DEC & JAN & FEB & MAR & APR & MAY & JUN & JUL & AUG & SEP \\
\hline 1 & e0.00 & 0.06 & e2. 7 & e 0.00 & e0 0.00 & e0 0.00 & e10 & e 0.00 & e 0.00 & e0.00 & e 0.00 & $\mathrm{e} 0.00$ \\
\hline 2 & $\mathrm{e} 0.00$ & $\mathrm{e} 0.02$ & e1.3 & $\mathrm{e} 0.00$ & $\mathrm{e} 0.00$ & $\mathrm{e} 0.00$ & e8. 8 & $\mathrm{e} 0.00$ & $\mathrm{e} 0.00$ & $\mathrm{e} 0.02$ & $\mathrm{e} 0.00$ & $\mathrm{e} 0.00$ \\
\hline 3 & $\mathrm{e} 0.00$ & $\mathrm{e} 0.00$ & e0.99 & $\mathrm{e} 0.00$ & 1.8 & $\mathrm{e} 0.00$ & e6. 3 & $\mathrm{e} 0.00$ & $\mathrm{e} 0.00$ & $\mathrm{e} 0.01$ & $\mathrm{e} 0.00$ & $\mathrm{e} 0.00$ \\
\hline 4 & $\mathrm{e} 0.00$ & e0.00 & e 0.75 & e 0.00 & 11 & e0.00 & e 4.1 & e 0.00 & e 0.00 & e0.00 & e 0.00 & $\mathrm{e} 0.00$ \\
\hline 5 & $e 0.00$ & e 0.00 & $e 0.67$ & e 0.00 & $e 0.05$ & e 0.00 & e2. 8 & e 0.00 & e 0.00 & $e 0.00$ & e 0.00 & $\mathrm{e} 0.02$ \\
\hline 6 & e0.00 & e 0.00 & e0.83 & e 0.00 & e0 0.00 & e0.00 & $\mathrm{e} 2.0$ & e 0.00 & e 0.00 & $\mathrm{e} 0.00$ & e 0.04 & e0.02 \\
\hline 7 & e0.00 & e 0.00 & e3. 5 & e 0.00 & e0 0.00 & e0.00 & e1.3 & e 0.00 & e 0.00 & $\mathrm{e} 0.00$ & 66 & e0.04 \\
\hline 8 & $\mathrm{e} 0.00$ & $\mathrm{e} 0.00$ & e1. 5 & $\mathrm{e} 0.00$ & $\mathrm{e} 0.00$ & $\mathrm{e} 0.00$ & $\mathrm{e} 0.79$ & $\mathrm{e} 0.00$ & $\mathrm{e} 0.00$ & $\mathrm{e} 0.05$ & e1.3 & $\mathrm{e} 0.02$ \\
\hline 9 & $\mathrm{e} 0.00$ & $\mathrm{e} 0.00$ & $\mathrm{e} 0.74$ & $\mathrm{e} 0.00$ & $\mathrm{e} 0.00$ & $\mathrm{e} 0.00$ & e1.8 & $\mathrm{e} 0.00$ & $\mathrm{e} 0.00$ & $\mathrm{e} 0.28$ & e0.93 & $\mathrm{e} 0.00$ \\
\hline 10 & e 0.00 & e 0.00 & e 0.48 & e 0.01 & $e 0.00$ & e 0.00 & el.1 & e 0.00 & e 0.00 & $e 0.25$ & e1.0 & e0.05 \\
\hline 11 & $\mathrm{e} 0.00$ & $\mathrm{e} 0.00$ & $\mathrm{e} 0.45$ & e0.05 & $\mathrm{e} 0.00$ & $\mathrm{e} 0.00$ & e2. 8 & $\mathrm{e} 0.00$ & $\mathrm{e} 0.00$ & $\mathrm{e} 0.33$ & e 0.88 & $\mathrm{e} 0.03$ \\
\hline 12 & $\mathrm{e} 0.00$ & e0.00 & e0.33 & e0.00 & $\mathrm{e} 0.00$ & $\mathrm{e} 0.00$ & e 4.0 & e 0.00 & e0.07 & e 0.17 & $e 0.67$ & $e 0.02$ \\
\hline 13 & $\mathrm{e} 0.00$ & e0.00 & e 0.24 & e0.00 & $\mathrm{e} 0.00$ & e 0.00 & el.7 & e 0.00 & e 0.02 & $\mathrm{e} 0.14$ & e 0.51 & e0.19 \\
\hline 14 & $e 0.00$ & $e 0.00$ & e 0.17 & $e 0.00$ & $e 0.00$ & $e 0.00$ & e3. 9 & e 0.00 & $\mathrm{e} 0.00$ & $e 0.66$ & e0.38 & e3.7 \\
\hline 15 & $\mathrm{e} 0.00$ & 5.6 & e0.09 & e0.00 & e 0.00 & e0.00 & e4.7 & e 0.00 & e 0.00 & $\mathrm{e} 0.23$ & e 0.27 & e56 \\
\hline 16 & $\mathrm{e} 0.00$ & 0.50 & e0.06 & e0.00 & e 0.00 & $\mathrm{e} 0.00$ & e 4.9 & $\mathrm{e} 0.00$ & $\mathrm{e} 0.00$ & $\mathrm{e} 0.09$ & $\mathrm{e} 0.20$ & $\mathrm{e} 4.3$ \\
\hline 17 & $\mathrm{e} 0.00$ & e 0.12 & e0.05 & e0.00 & e 0.00 & $\mathrm{e} 0.00$ & e3.0 & e 0.00 & e 0.00 & $\mathrm{e} 0.07$ & e 0.11 & e1.9 \\
\hline 18 & $\mathrm{e} 0.00$ & $\mathrm{e} 0.12$ & $\mathrm{e} 0.04$ & $\mathrm{e} 0.00$ & $\mathrm{e} 0.00$ & $\mathrm{e} 0.00$ & e2.1 & $\mathrm{e} 0.00$ & $\mathrm{e} 0.00$ & $\mathrm{e} 0.06$ & e0.08 & e1.6 \\
\hline 19 & e0.06 & e 0.12 & e0.02 & e 0.00 & e 0.00 & e0.00 & e1. 6 & e 0.00 & e 0.00 & e0.05 & e 0.16 & e1.1 \\
\hline 20 & 0.31 & $\mathrm{e} 0.10$ & $\mathrm{e} 0.01$ & $\mathrm{e} 0.00$ & $\mathrm{e} 0.00$ & $\mathrm{e} 0.00$ & e1.2 & e 0.00 & e 0.00 & $e 0.03$ & $e 0.46$ & $e 0.78$ \\
\hline 21 & $\mathrm{e} 0.00$ & e0.09 & $\mathrm{e} 0.01$ & $\mathrm{e} 0.00$ & $\mathrm{e} 0.00$ & $\mathrm{e} 0.00$ & e0.87 & $\mathrm{e} 0.00$ & $\mathrm{e} 0.00$ & $\mathrm{e} 0.02$ & $\mathrm{e} 0.02$ & $\mathrm{e} 0.53$ \\
\hline 22 & e0.00 & e0.08 & e0.00 & e0.00 & e 0.00 & e0.00 & e0.64 & e 0.00 & e 0.12 & e0.02 & e0.01 & $\mathrm{e} 1.4$ \\
\hline 23 & e0.00 & e0.06 & e0.00 & e0.00 & e 0.00 & e0 0.00 & e0.49 & e 0.00 & e0.17 & $\mathrm{e} 0.01$ & e 0.00 & e0.79 \\
\hline 24 & $\mathrm{e} 0.00$ & $\mathrm{e} 0.04$ & $\mathrm{e} 0.00$ & $\mathrm{e} 0.00$ & $\mathrm{e} 0.00$ & $\mathrm{e} 0.00$ & e0.38 & $\mathrm{e} 0.00$ & e0.11 & $\mathrm{e} 0.00$ & $\mathrm{e} 0.00$ & $\mathrm{e} 0.48$ \\
\hline 25 & $\mathrm{e} 0.00$ & 0.15 & e0.00 & e0.00 & e 0.00 & e 0.00 & e 0.27 & e 0.00 & $e 0.03$ & $\mathrm{e} 0.00$ & e0.00 & $\mathrm{e} 0.40$ \\
\hline 26 & $\mathrm{e} 0.00$ & e0.11 & e0.00 & e0.00 & e0.00 & e0.00 & e0.19 & e 0.00 & e 0.00 & $\mathrm{e} 0.00$ & e0.00 & $\mathrm{e} 0.50$ \\
\hline 27 & e0.00 & e0.05 & e0.01 & e 0.00 & $\mathrm{e} 0.00$ & 0.43 & e0.19 & $\mathrm{e} 0.00$ & e 0.00 & $\mathrm{e} 0.00$ & e 0.00 & e0.53 \\
\hline 28 & e0.00 & e0.11 & e0.00 & e0.00 & e0.00 & 8.7 & e0.10 & e 0.00 & e 0.00 & $\mathrm{e} 0.00$ & e0.00 & $\mathrm{e} 0.44$ \\
\hline 29 & e0.00 & 0.30 & e0.00 & e0.00 & --- & e2. 0 & e0.04 & e 0.00 & e 0.00 & $\mathrm{e} 0.01$ & e0.00 & $\mathrm{e} 0.36$ \\
\hline 30 & $\mathrm{e} 0.00$ & 0.40 & e0.00 & e 0.00 & --- & 11 & e0.02 & e 0.00 & e 0.00 & e0.00 & e 0.00 & e8. 8 \\
\hline 31 & 0.12 & --- & $\mathrm{e} 0.00$ & $\mathrm{e} 0.00$ & --- & e7. 1 & --- & $\mathrm{e} 0.00$ & --- & $\mathrm{e} 0.00$ & $\mathrm{e} 0.00$ & --- \\
\hline TOTAL & 0.49 & 8.03 & 14.94 & 0.06 & 12.85 & 29.23 & 72.08 & 0.00 & 0.52 & 2.50 & 73.02 & 84.00 \\
\hline MAX & 0.31 & 5.6 & 3.5 & 0.05 & 11 & 11 & 10 & 0.00 & 0.17 & 0.66 & 66 & 56 \\
\hline MIN & 0.00 & 0.00 & 0.00 & 0.00 & 0.00 & 0.00 & 0.02 & 0.00 & 0.00 & 0.00 & 0.00 & 0.00 \\
\hline TOTAL Q & 26.02 & 358.72 & 473.60 & 9.15 & 120.59 & 476.18 & 1328.6 & 1.21 & 62.44 & 207.37 & 441.08 & 1074.80 \\
\hline WTR YR & 2005 & TOTAL 297.7 & 72 MEAN & 0.82 MAX & 66 MIN & $0.00 \quad$ MED & 0.00 & & & & & \\
\hline
\end{tabular}


Table 16A. Daily-mean loads of total nitrogen during October 1, 2003, to September 30, 2004, Waiakea Stream at Hoaka Road (16700600), Hilo, Hawaii.

\section{STATION NUMBER 16700600 Waiakea Stream at Hoaka Road, Hawaii LATITUDE 193940 LONGITUDE 1550720 NAD83 \\ Total nitrogen, water, unfiltered, pounds per day WATER YEAR OCTOBER 2003 TO SEPTEMBER 2004 DAILY MEAN VALUES}

\begin{tabular}{|c|c|c|c|c|c|c|c|c|c|c|c|c|}
\hline DAY & OCT & NOV & $\mathrm{DEC}$ & JAN & FEB & MAR & $\mathrm{APR}$ & MAY & JUN & JUL & AUG & SEP \\
\hline 1 & e0.00 & $\mathrm{e} 0.00$ & e18. 6 & $\mathrm{e} 0.63$ & e 104 & $\mathrm{e} 0.64$ & e116 & e2.34 & e3.70 & $\mathrm{e} 0.00$ & $\mathrm{e} 0.00$ & $\mathrm{e} 0.00$ \\
\hline 2 & e0.00 & e0.00 & e11.8 & e 0.10 & e93. 3 & $\mathrm{e} 0.22$ & e95.8 & e1.45 & e1. 50 & $\mathrm{e} 0.00$ & e 0.00 & $\mathrm{e} 0.00$ \\
\hline 3 & e0.00 & $\mathrm{e} 0.00$ & e14.2 & $\mathrm{e} 0.00$ & e79. 4 & $\mathrm{e} 0.18$ & e76. 5 & e0.97 & $\mathrm{e} 0.52$ & $\mathrm{e} 0.00$ & $\mathrm{e} 0.00$ & $\mathrm{e} 0.00$ \\
\hline 4 & e0.00 & $\mathrm{e} 0.00$ & e21.3 & $\mathrm{e} 0.00$ & e49.1 & $\mathrm{e} 0.17$ & e58.1 & e2.79 & $\mathrm{e} 0.23$ & $\mathrm{e} 0.00$ & $\mathrm{e} 0.00$ & $\mathrm{e} 0.00$ \\
\hline 5 & e0.00 & $\mathrm{e} 0.00$ & e9.37 & $\mathrm{e} 0.02$ & e 41.3 & $\mathrm{e} 0.66$ & e49.6 & e2.15 & e0.50 & $\mathrm{e} 0.00$ & $\mathrm{e} 0.00$ & $\mathrm{e} 0.00$ \\
\hline 6 & e0.00 & $\mathrm{e} 0.00$ & e39.2 & $\mathrm{e} 0.00$ & e 89.4 & $\mathrm{e} 0.41$ & e 36.0 & e1.03 & e0.51 & $\mathrm{e} 0.00$ & $\mathrm{e} 0.00$ & $\mathrm{e} 0.00$ \\
\hline 7 & $e 0.00$ & $\mathrm{e} 0.00$ & e8.06 & e 0.00 & e72. 8 & e0.07 & e25.7 & e0.67 & e0.21 & $\mathrm{e} 0.00$ & e0.00 & $\mathrm{e} 0.00$ \\
\hline 8 & e0.00 & $\mathrm{e} 0.00$ & e6. 23 & e 0.00 & e 32.2 & e1.90 & e19.4 & e0.49 & $\mathrm{e} 0.06$ & $\mathrm{e} 0.00$ & $\mathrm{e} 0.00$ & $\mathrm{e} 0.00$ \\
\hline 9 & e0.00 & $\mathrm{e} 0.00$ & e9. 80 & e 0.00 & e16. 6 & $\mathrm{e} 0.63$ & e17. 5 & $\mathrm{e} 0.36$ & $\mathrm{e} 0.00$ & $\mathrm{e} 0.00$ & $\mathrm{e} 0.00$ & $\mathrm{e} 0.00$ \\
\hline 10 & $\mathrm{e} 0.00$ & $\mathrm{e} 0.00$ & e 48.0 & e 0.00 & e12. 5 & $\mathrm{e} 0.11$ & e73.9 & $\mathrm{e} 0.24$ & e0.92 & $\mathrm{e} 0.00$ & $\mathrm{e} 0.00$ & $\mathrm{e} 0.00$ \\
\hline 11 & $\mathrm{e} 0.00$ & $\mathrm{e} 0.00$ & e 57.0 & $\mathrm{e} 0.00$ & e10.3 & $\mathrm{e} 0.00$ & e574 & e0.16 & e15. 5 & $\mathrm{e} 0.27$ & $\mathrm{e} 0.00$ & $\mathrm{e} 0.00$ \\
\hline 12 & $\mathrm{e} 0.00$ & e1.07 & e9. 68 & e 0.00 & e8. 54 & $\mathrm{e} 0.00$ & e1350 & e 55.7 & e11.7 & $\mathrm{e} 0.00$ & $\mathrm{e} 0.00$ & $\mathrm{e} 0.00$ \\
\hline 13 & $\mathrm{e} 0.00$ & e0.05 & e6.38 & $\mathrm{e} 0.00$ & e6.78 & $\mathrm{e} 0.33$ & e472 & e8.78 & e7.01 & $\mathrm{e} 0.00$ & $\mathrm{e} 0.00$ & $\mathrm{e} 0.00$ \\
\hline 14 & $\mathrm{e} 0.00$ & $\mathrm{e} 0.00$ & e4.93 & $\mathrm{e} 0.00$ & e5.08 & 786 & e259 & e5. 25 & e1.00 & e3.86 & $\mathrm{e} 0.00$ & $\mathrm{e} 0.00$ \\
\hline 15 & $\mathrm{e} 0.00$ & $\mathrm{e} 0.01$ & e3.99 & e 0.00 & e3. 51 & e717 & e139 & e3.81 & $\mathrm{e} 0.12$ & $\mathrm{e} 0.74$ & $\mathrm{e} 0.00$ & $\mathrm{e} 0.00$ \\
\hline 16 & $\mathrm{e} 0.00$ & e71.2 & e2.92 & $\mathrm{e} 0.00$ & e2.53 & e 42.0 & e59.9 & e3.22 & $\mathrm{e} 0.06$ & $\mathrm{e} 0.06$ & $\mathrm{e} 0.00$ & $\mathrm{e} 0.00$ \\
\hline 17 & e0.00 & e16. 6 & e1.99 & e0.00 & e2.04 & e 30.1 & e119 & e2. 63 & e0.02 & $\mathrm{e} 0.00$ & e0.00 & $\mathrm{e} 0.00$ \\
\hline 18 & e0.00 & e7.80 & e1.27 & e0.00 & e1.30 & e22. 8 & e57.0 & e1.92 & $\mathrm{e} 0.00$ & $\mathrm{e} 0.00$ & $\mathrm{e} 0.00$ & $\mathrm{e} 0.00$ \\
\hline 19 & $\mathrm{e} 0.00$ & e6. 66 & e0.73 & $\mathrm{e} 0.00$ & $\mathrm{e} 0.72$ & e16.9 & e 43.6 & e3.67 & $\mathrm{e} 0.00$ & $\mathrm{e} 0.00$ & $\mathrm{e} 0.00$ & $\mathrm{e} 0.00$ \\
\hline 20 & e0.00 & e3.89 & e0.39 & e 0.00 & e0.33 & e12.1 & e38.2 & e3. 46 & e0.00 & $\mathrm{e} 0.00$ & $\mathrm{e} 0.00$ & $\mathrm{e} 0.00$ \\
\hline 21 & $\mathrm{e} 0.00$ & e2.78 & $\mathrm{e} 0.17$ & e 0.00 & $\mathrm{e} 0.13$ & e8.60 & e29.6 & e0.51 & $\mathrm{e} 0.00$ & $\mathrm{e} 0.00$ & $\mathrm{e} 0.00$ & $\mathrm{e} 0.00$ \\
\hline 22 & $\mathrm{e} 0.00$ & e2. 14 & $\mathrm{e} 0.03$ & e 0.00 & e0.05 & e9.91 & e23. 6 & $\mathrm{e} 0.10$ & $\mathrm{e} 0.00$ & $\mathrm{e} 0.00$ & $\mathrm{e} 0.00$ & $\mathrm{e} 0.00$ \\
\hline 23 & e0.00 & e1.58 & $\mathrm{e} 0.00$ & e2. 40 & e0.00 & e149 & e21.8 & e0.00 & e0.00 & $\mathrm{e} 0.00$ & e0.00 & $\mathrm{e} 0.00$ \\
\hline 24 & $\mathrm{e} 0.00$ & e1.13 & $\mathrm{e} 0.00$ & e0.87 & $\mathrm{e} 0.00$ & e394 & e17.9 & e0.00 & e 0.00 & $\mathrm{e} 0.00$ & e0.00 & $\mathrm{e} 0.00$ \\
\hline 25 & e0.00 & $\mathrm{e} 0.73$ & $\mathrm{e} 0.00$ & e534 & $\mathrm{e} 0.00$ & e148 & e13.8 & $\mathrm{e} 0.00$ & e0.00 & $\mathrm{e} 0.00$ & $\mathrm{e} 0.00$ & $\mathrm{e} 0.00$ \\
\hline 26 & e0.00 & e 0.44 & e0.00 & e 48.4 & e0.00 & e116 & e9.58 & e0.50 & e0.00 & $\mathrm{e} 0.00$ & e0.00 & $\mathrm{e} 0.00$ \\
\hline 27 & $\mathrm{e} 0.00$ & $\mathrm{e} 0.26$ & $\mathrm{e} 0.00$ & e 4.25 & $\mathrm{e} 0.00$ & e152 & e7.33 & e6.05 & $\mathrm{e} 0.00$ & $\mathrm{e} 0.00$ & $\mathrm{e} 0.00$ & $\mathrm{e} 0.00$ \\
\hline 28 & $\mathrm{e} 0.00$ & $\mathrm{e} 0.11$ & $\mathrm{e} 0.00$ & e1.57 & e17.1 & e113 & e 5.70 & e7.10 & $\mathrm{e} 0.00$ & $\mathrm{e} 0.00$ & $\mathrm{e} 0.00$ & $\mathrm{e} 0.00$ \\
\hline 29 & e0.00 & e53. 8 & e9.52 & e233 & e3. 20 & e76. 6 & e4.54 & e2.15 & e0.00 & $\mathrm{e} 0.00$ & $\mathrm{e} 0.00$ & $\mathrm{e} 0.00$ \\
\hline 30 & $\mathrm{e} 0.00$ & e119 & $\mathrm{e} 8.22$ & e106 & --- & e129 & e3.39 & e2.36 & $\mathrm{e} 0.00$ & $\mathrm{e} 0.00$ & $\mathrm{e} 0.00$ & $\mathrm{e} 0.00$ \\
\hline 31 & $\mathrm{e} 0.00$ & --- & e2. 50 & e181 & --- & e379 & --- & e8. 56 & --- & $\mathrm{e} 0.00$ & $\mathrm{e} 0.00$ & --- \\
\hline TOTAL & 0.00 & 289.25 & 296.28 & 1112.24 & 652.21 & 3307.33 & 3817.44 & 128.42 & 43.56 & 4.93 & 0.00 & 0.00 \\
\hline MAX & 0.00 & 119 & 57.0 & 534 & 104 & 786 & 1350 & 55.7 & 15.5 & 3.86 & 0.00 & 0.00 \\
\hline MIN & 0.00 & 0.00 & 0.00 & 0.00 & 0.00 & 0.00 & 3.39 & 0.00 & 0.00 & 0.00 & 0.00 & 0.00 \\
\hline TOTAL Q & 0.00 & 265.77 & 371.41 & 564.37 & 526.08 & 1808.74 & 2454 & 192.44 & 67.04 & 6.33 & 0.04 & 0.00 \\
\hline WTR YR & 2004 & TOTAL 9651 & .66 MEAN & N 26.4 & MAX 1350 & MIN 0.00 & MED 0.03 & & & & & \\
\hline
\end{tabular}


Table 16B. Daily-mean loads of total nitrogen during October 1, 2004, to September 30, 2005, Waiakea Stream at Hoaka Road (16700600), Hilo, Hawaii.

\section{STATION NUMBER 16700600 Waiakea Stream at Hoaka Road, Hawaii LATITUDE 193940 LONGITUDE 1550720 NAD83 \\ Total nitrogen, water, unfiltered, pounds per day WATER YEAR OCTOBER 2004 TO SEPTEMBER 2005 DAILY MEAN VALUES}

\begin{tabular}{|c|c|c|c|c|c|c|c|c|c|c|c|c|}
\hline DAY & OCT & NOV & $\mathrm{DEC}$ & JAN & FEB & MAR & APR & MAY & JUN & JUL & AUG & $\mathrm{SEP}$ \\
\hline 1 & $\mathrm{e} 0.00$ & e6. 50 & e91.3 & $\mathrm{e} 0.10$ & $\mathrm{e} 0.00$ & $\mathrm{e} 0.00$ & e129 & $\mathrm{e} 0.00$ & $\mathrm{e} 0.00$ & $\mathrm{e} 0.00$ & e0.00 & $\mathrm{e} 0.00$ \\
\hline 2 & $\mathrm{e} 0.00$ & e1.35 & e21. 6 & $\mathrm{e} 0.10$ & 0.00 & $\mathrm{e} 0.00$ & e104 & $\mathrm{e} 0.00$ & $\mathrm{e} 0.00$ & $\mathrm{e} 0.36$ & $\mathrm{e} 0.00$ & $\mathrm{e} 0.00$ \\
\hline 3 & $\mathrm{e} 0.00$ & $\mathrm{e} 0.02$ & e18.3 & $\mathrm{e} 0.00$ & 91.7 & $\mathrm{e} 0.00$ & e77.8 & $\mathrm{e} 0.00$ & $\mathrm{e} 0.00$ & e0.31 & $\mathrm{e} 0.00$ & $\mathrm{e} 0.00$ \\
\hline 4 & $\mathrm{e} 0.00$ & $\mathrm{e} 0.00$ & e16. 4 & $\mathrm{e} 0.00$ & e288 & $\mathrm{e} 0.00$ & e50.9 & $\mathrm{e} 0.00$ & $\mathrm{e} 0.00$ & $\mathrm{e} 0.06$ & $\mathrm{e} 0.00$ & $\mathrm{e} 0.00$ \\
\hline 5 & $\mathrm{e} 0.00$ & $\mathrm{e} 0.00$ & e18. 3 & $\mathrm{e} 0.00$ & e20.1 & $\mathrm{e} 0.00$ & e32.9 & $\mathrm{e} 0.00$ & $\mathrm{e} 0.00$ & $\mathrm{e} 0.00$ & $\mathrm{e} 0.00$ & $\mathrm{e} 2.07$ \\
\hline 6 & $\mathrm{e} 0.00$ & $\mathrm{e} 0.00$ & e 40.2 & $\mathrm{e} 0.00$ & e1. 40 & $\mathrm{e} 0.00$ & e25. 8 & $\mathrm{e} 0.00$ & $\mathrm{e} 0.00$ & $\mathrm{e} 0.00$ & $\mathrm{e} 0.68$ & e2. 48 \\
\hline 7 & $\mathrm{e} 0.00$ & $\mathrm{e} 0.00$ & 87.3 & $\mathrm{e} 0.00$ & e0.06 & $\mathrm{e} 0.00$ & e20.4 & $\mathrm{e} 0.00$ & $\mathrm{e} 0.00$ & $\mathrm{e} 0.00$ & e499 & e4.68 \\
\hline 8 & $\mathrm{e} 0.00$ & $\mathrm{e} 0.00$ & e 44.0 & $\mathrm{e} 0.00$ & e0.00 & $\mathrm{e} 0.00$ & e15.7 & $\mathrm{e} 0.00$ & $\mathrm{e} 0.00$ & e3.30 & e49.6 & e3.61 \\
\hline 9 & $\mathrm{e} 0.00$ & $\mathrm{e} 0.00$ & e 30.2 & $\mathrm{e} 0.00$ & $\mathrm{e} 0.00$ & $\mathrm{e} 0.00$ & e27.0 & $\mathrm{e} 0.00$ & $\mathrm{e} 0.00$ & e4.99 & e39. 2 & e1.13 \\
\hline 10 & $\mathrm{e} 0.00$ & $\mathrm{e} 0.00$ & e25.0 & $\mathrm{e} 2.00$ & $\mathrm{e} 0.00$ & $\mathrm{e} 0.00$ & e16.7 & $\mathrm{e} 0.00$ & $\mathrm{e} 0.00$ & e14.9 & e 38.2 & e4.11 \\
\hline 11 & $\mathrm{e} 0.00$ & e 0.00 & e13.0 & e1.68 & e0.00 & $\mathrm{e} 0.00$ & e37.3 & e 0.00 & $\mathrm{e} 0.00$ & e17.0 & e33.7 & e2.55 \\
\hline 12 & $\mathrm{e} 0.00$ & $\mathrm{e} 0.00$ & e10.3 & $\mathrm{e} 0.02$ & e0.00 & $\mathrm{e} 0.00$ & e 55.2 & $\mathrm{e} 0.00$ & e3.51 & e10.4 & e26.9 & e1.62 \\
\hline 13 & $\mathrm{e} 0.00$ & $\mathrm{e} 0.00$ & e7.80 & $\mathrm{e} 0.00$ & e0.00 & $\mathrm{e} 0.00$ & e27.4 & $\mathrm{e} 0.00$ & $\mathrm{e} 0.81$ & e9.98 & e22.1 & e18.2 \\
\hline 14 & $\mathrm{e} 0.00$ & $\mathrm{e} 0.00$ & e6.20 & $\mathrm{e} 0.00$ & e0.00 & $\mathrm{e} 0.00$ & e110 & $\mathrm{e} 0.00$ & $\mathrm{e} 0.00$ & e61.3 & e18.0 & e77.1 \\
\hline 15 & $\mathrm{e} 0.00$ & 300 & e4.70 & $\mathrm{e} 0.00$ & $\mathrm{e} 0.00$ & $\mathrm{e} 0.00$ & e82. 8 & $\mathrm{e} 0.00$ & $\mathrm{e} 0.00$ & e19.5 & e14.2 & e899 \\
\hline 16 & $\mathrm{e} 0.00$ & e52.8 & e2.90 & $\mathrm{e} 0.00$ & e0.00 & $\mathrm{e} 0.00$ & e77.5 & $\mathrm{e} 0.00$ & $\mathrm{e} 0.00$ & e6.31 & e11.6 & e106 \\
\hline 17 & $\mathrm{e} 0.00$ & e15. 1 & e2.30 & $\mathrm{e} 0.00$ & e0.00 & $\mathrm{e} 0.00$ & e 50.2 & $\mathrm{e} 0.00$ & $\mathrm{e} 0.00$ & e 4.75 & e7.89 & e55.6 \\
\hline 18 & $\mathrm{e} 0.00$ & e15.9 & e1.90 & $\mathrm{e} 0.00$ & e0.00 & $\mathrm{e} 0.00$ & e 34.5 & $\mathrm{e} 0.00$ & $\mathrm{e} 0.00$ & e3.92 & e5.85 & e 47.4 \\
\hline 19 & e2.75 & e16. 6 & e1.60 & $\mathrm{e} 0.00$ & e0.00 & $\mathrm{e} 0.00$ & e24.5 & $\mathrm{e} 0.00$ & $\mathrm{e} 0.00$ & e2.93 & e7.66 & e36.4 \\
\hline 20 & 23.5 & e16.0 & e1.10 & $\mathrm{e} 0.00$ & e0.00 & $\mathrm{e} 0.00$ & e17. 2 & $\mathrm{e} 0.00$ & $\mathrm{e} 0.00$ & e1.90 & e33.0 & e27.0 \\
\hline 21 & $\mathrm{e} 0.15$ & e15.0 & $\mathrm{e} 0.90$ & $\mathrm{e} 0.00$ & e0.00 & $\mathrm{e} 0.00$ & e11.4 & $\mathrm{e} 0.00$ & $\mathrm{e} 0.00$ & e1.25 & e9.05 & $\mathrm{e} 20.2$ \\
\hline 22 & $\mathrm{e} 0.00$ & e13.9 & $\mathrm{e} 0.60$ & $\mathrm{e} 0.00$ & e0.00 & $\mathrm{e} 0.00$ & e7.87 & $\mathrm{e} 0.00$ & e8.01 & $\mathrm{e} 0.97$ & e4.94 & e56.9 \\
\hline 23 & $\mathrm{e} 0.00$ & e12.0 & e0.30 & $\mathrm{e} 0.00$ & e0.00 & $\mathrm{e} 0.00$ & e5. 82 & $\mathrm{e} 0.00$ & e11.4 & $\mathrm{e} 0.47$ & e3.16 & e 32.2 \\
\hline 24 & $\mathrm{e} 0.00$ & e9.21 & $\mathrm{e} 0.10$ & $\mathrm{e} 0.00$ & $\mathrm{e} 0.00$ & $\mathrm{e} 0.00$ & e4.28 & $\mathrm{e} 0.00$ & e8.69 & e0.19 & e2.01 & e18.7 \\
\hline 25 & e 0.00 & 14.8 & e0.10 & $\mathrm{e} 0.00$ & e0.00 & e0.00 & e2.89 & e0.00 & e1.94 & e0.02 & e1.21 & e17.2 \\
\hline 26 & e0.01 & e6.98 & e 0.00 & $\mathrm{e} 0.00$ & e 0.00 & e0.00 & e1.83 & e 0.00 & e0.08 & $\mathrm{e} 0.00$ & e0.49 & e 40.2 \\
\hline 27 & e0.00 & e2. 63 & e0.00 & $\mathrm{e} 0.00$ & e0.00 & 12.5 & e1.57 & $e 0.00$ & e 0.00 & e0.00 & e0.11 & e 43.3 \\
\hline 28 & $\mathrm{e} 0.00$ & e7.24 & $\mathrm{e} 0.50$ & $\mathrm{e} 0.00$ & e0.00 & 156 & $\mathrm{e} 0.67$ & $\mathrm{e} 0.00$ & $\mathrm{e} 0.00$ & $\mathrm{e} 0.00$ & $\mathrm{e} 0.01$ & e25.4 \\
\hline 29 & $\mathrm{e} 0.00$ & 31.9 & e0.30 & $\mathrm{e} 0.00$ & --- & e59.5 & e0.19 & $e 0.00$ & e0.00 & e0.00 & e0.00 & e17.8 \\
\hline 30 & $\mathrm{e} 0.23$ & 16.6 & $\mathrm{e} 0.20$ & $\mathrm{e} 0.00$ & --- & 192 & $\mathrm{e} 0.01$ & $\mathrm{e} 0.00$ & $\mathrm{e} 0.00$ & $\mathrm{e} 0.00$ & $\mathrm{e} 0.00$ & e179 \\
\hline 31 & e24.7 & --- & e0.10 & $\mathrm{e} 0.00$ & --- & e 124 & --- & $\mathrm{e} 0.00$ & --- & $\mathrm{e} 0.00$ & $\mathrm{e} 0.00$ & --- \\
\hline TOTAL & 51.34 & 554.53 & 447.50 & 3.90 & 401.26 & 544.00 & 1053.33 & 0.00 & 34.44 & 164.81 & 828.56 & 1739.85 \\
\hline MAX & 24.7 & 300 & 91.3 & 2.00 & 288 & 192 & 129 & 0.00 & 11.4 & 61.3 & 499 & 899 \\
\hline MIN & 0.00 & 0.00 & 0.00 & 0.00 & 0.00 & 0.00 & 0.01 & 0.00 & 0.00 & 0.00 & 0.00 & 0.00 \\
\hline TOTAL & Q 26.02 & 358.72 & 473.60 & 9.15 & 120.59 & 476.18 & 1328.6 & 1.21 & 62.44 & 207.37 & 441.08 & 1074.80 \\
\hline WTR YR & 2005 & TOTAL 582 & .52 MEAN & 16.0 & MAX 899 & MIN 0.00 & MED 0.00 & & & & & \\
\hline
\end{tabular}


Table 17A. Daily-mean loads of nitrogen, nitrite plus nitrate, dissolved, during October 1, 2003, to September 30, 2004, Waiakea Stream at Hoaka Road (16700600), Hilo, Hawaii.

\section{STATION NUMBER 16700600 Waiakea Stream at Hoaka Road, Hawai LATITUDE 193940 LONGITUDE 1550720 NAD83 \\ Nitrogen, nitrite + nitrate, dissolved, Ibs/day as $\mathbf{N}$ WATER YEAR OCTOBER 2003 TO SEPTEMBER 2004 DAILY MEAN VALUES}

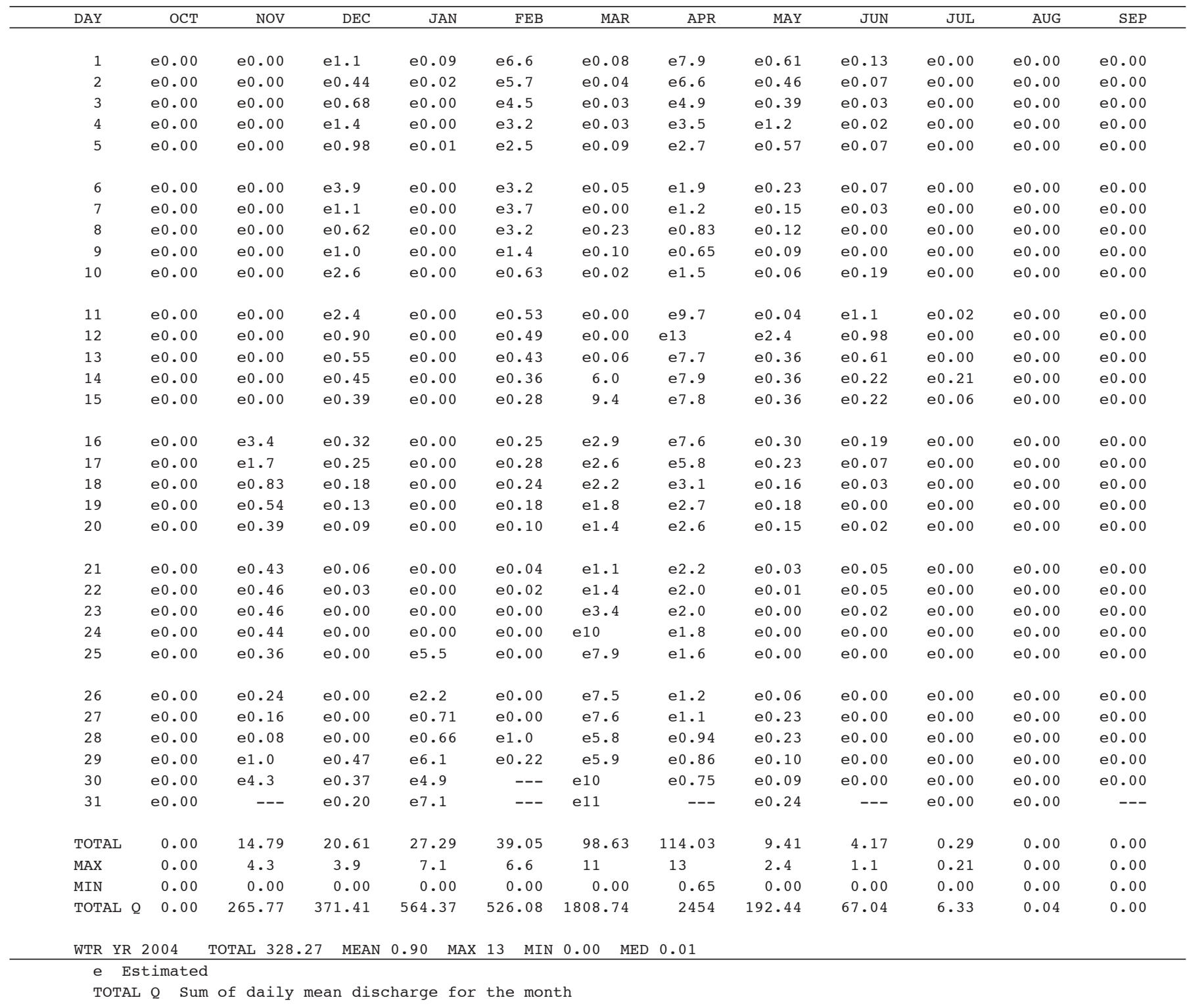


Table 17B. Daily-mean loads of nitrogen, nitrite plus nitrate, dissolved, during October 1, 2004, to September 30, 2005, Waiakea Stream at Hoaka Road (16700600), Hilo, Hawaii.

STATION NUMBER 16700600 Waiakea Stream at Hoaka Road, Hawaii

LATITUDE 193940 LONGITUDE 1550720 NAD83

Nitrogen, nitrite + nitrate, dissolved, Ibs/day as $\mathbf{N}$

WATER YEAR OCTOBER 2004 TO SEPTEMBER 2005

DAILY MEAN VALUES

\begin{tabular}{|c|c|c|c|c|c|c|c|c|c|c|c|c|}
\hline DAY & $\mathrm{OCT}$ & NOV & DEC & JAN & FEB & MAR & APR & MAY & JUN & JUL & AUG & SEP \\
\hline 1 & e0.00 & e0.30 & e1.9 & e0.05 & e0 0.00 & e0 0.00 & e7.1 & e0.00 & e 0.00 & e0.00 & e 0.00 & $\mathrm{e} 0.00$ \\
\hline 2 & $\mathrm{e} 0.00$ & $\mathrm{e} 0.05$ & e1.1 & $\mathrm{e} 0.04$ & $\mathrm{e} 0.00$ & $\mathrm{e} 0.00$ & e4.1 & $\mathrm{e} 0.00$ & $\mathrm{e} 0.00$ & $\mathrm{e} 0.03$ & $\mathrm{e} 0.00$ & $\mathrm{e} 0.00$ \\
\hline 3 & $\mathrm{e} 0.00$ & $\mathrm{e} 0.00$ & e1.1 & $\mathrm{e} 0.04$ & 0.85 & $\mathrm{e} 0.00$ & e 4.0 & $\mathrm{e} 0.00$ & $\mathrm{e} 0.00$ & $\mathrm{e} 0.02$ & $\mathrm{e} 0.00$ & $\mathrm{e} 0.00$ \\
\hline 4 & $\mathrm{e} 0.00$ & e0.00 & e1.2 & e 0.00 & 8.4 & e0.00 & e3. 2 & e0.00 & e 0.00 & e0.02 & e 0.00 & $\mathrm{e} 0.00$ \\
\hline 5 & $e 0.00$ & e 0.00 & e1.7 & e 0.00 & e0.38 & e 0.00 & e2. 6 & e 0.00 & e 0.00 & $e 0.00$ & e 0.00 & $\mathrm{e} 0.07$ \\
\hline 6 & e0.00 & e 0.00 & e2. 0 & e 0.00 & e0.04 & e0.00 & e2. 3 & e0.00 & e 0.00 & $\mathrm{e} 0.00$ & e0.02 & e0.08 \\
\hline 7 & e0.00 & e 0.00 & 3.8 & e 0.00 & e 0.00 & e0.00 & e1.9 & e0.00 & e 0.00 & $\mathrm{e} 0.00$ & e6. 3 & $\mathrm{e} 0.14$ \\
\hline 8 & $\mathrm{e} 0.00$ & $\mathrm{e} 0.00$ & $\mathrm{e} 1.2$ & $\mathrm{e} 0.00$ & $\mathrm{e} 0.00$ & $\mathrm{e} 0.00$ & e1. 6 & $\mathrm{e} 0.00$ & $\mathrm{e} 0.00$ & $\mathrm{e} 0.11$ & $\mathrm{e} 1.2$ & $\mathrm{e} 0.12$ \\
\hline 9 & $\mathrm{e} 0.00$ & $\mathrm{e} 0.00$ & e0.89 & $\mathrm{e} 0.00$ & $\mathrm{e} 0.00$ & $\mathrm{e} 0.00$ & $\mathrm{e} 2.4$ & $\mathrm{e} 0.00$ & $\mathrm{e} 0.00$ & $\mathrm{e} 0.73$ & $\mathrm{e} 1.2$ & $\mathrm{e} 0.04$ \\
\hline 10 & e 0.00 & e 0.00 & e 0.77 & e 0.13 & e 0.00 & e 0.00 & e2. 0 & e 0.00 & e 0.00 & $e 0.61$ & e1.3 & e 0.15 \\
\hline 11 & $\mathrm{e} 0.00$ & $\mathrm{e} 0.00$ & e1.0 & e0.34 & $\mathrm{e} 0.00$ & $\mathrm{e} 0.00$ & $\mathrm{e} 2.2$ & $\mathrm{e} 0.00$ & $\mathrm{e} 0.00$ & $\mathrm{e} 0.53$ & e1.3 & e0.09 \\
\hline 12 & $\mathrm{e} 0.00$ & e0.00 & e0.86 & e0.00 & $\mathrm{e} 0.00$ & $\mathrm{e} 0.00$ & e2. 6 & e 0.00 & e 0.00 & e0.31 & e1.1 & $\mathrm{e} 0.08$ \\
\hline 13 & $\mathrm{e} 0.00$ & e0.00 & e 0.72 & e0.00 & e 0.00 & e 0.00 & el. 6 & e 0.00 & e 0.00 & e0.33 & e0.94 & e0.39 \\
\hline 14 & $e 0.00$ & $e 0.00$ & e0.61 & $e 0.00$ & $e 0.00$ & $e 0.00$ & e2. 9 & e0.00 & $\mathrm{e} 0.00$ & $e 0.66$ & e0.82 & e1. 6 \\
\hline 15 & $\mathrm{e} 0.00$ & 5.9 & e0.50 & e0.00 & e 0.00 & $\mathrm{e} 0.00$ & e3. 4 & $\mathrm{e} 0.00$ & $\mathrm{e} 0.00$ & $\mathrm{e} 0.34$ & e0.69 & e8.1 \\
\hline 16 & $\mathrm{e} 0.00$ & e1. 5 & e0.36 & e0.00 & e 0.00 & $\mathrm{e} 0.00$ & e2. 9 & e0.00 & e 0.00 & $\mathrm{e} 0.20$ & e0.61 & $\mathrm{e} 2.3$ \\
\hline 17 & $\mathrm{e} 0.00$ & $e 0.65$ & e0.30 & e0.00 & e 0.00 & $\mathrm{e} 0.00$ & e1.8 & e0.00 & e 0.00 & e 0.17 & e 0.45 & e1. 6 \\
\hline 18 & $\mathrm{e} 0.00$ & $\mathrm{e} 0.74$ & $\mathrm{e} 0.26$ & $\mathrm{e} 0.00$ & $\mathrm{e} 0.00$ & $\mathrm{e} 0.00$ & e1.3 & $\mathrm{e} 0.00$ & $\mathrm{e} 0.00$ & e0.15 & e0.37 & e 1.4 \\
\hline 19 & e 0.20 & e 0.74 & e 0.23 & e 0.00 & e 0.00 & e 0.00 & e0.94 & e0.00 & e 0.00 & e 0.12 & e0.33 & e1.1 \\
\hline 20 & 0.57 & $\mathrm{e} 0.69$ & e0.18 & $\mathrm{e} 0.00$ & $\mathrm{e} 0.00$ & $\mathrm{e} 0.00$ & e0.69 & e 0.00 & e 0.00 & $e 0.08$ & $e 0.65$ & e0.78 \\
\hline 21 & $\mathrm{e} 0.00$ & $\mathrm{e} 0.63$ & e 0.15 & $\mathrm{e} 0.00$ & $\mathrm{e} 0.00$ & $\mathrm{e} 0.00$ & e0.49 & $\mathrm{e} 0.00$ & $\mathrm{e} 0.00$ & $\mathrm{e} 0.06$ & $\mathrm{e} 0.23$ & e0.58 \\
\hline 22 & e0.00 & e0.57 & e0.11 & e0.00 & e 0.00 & e0.00 & e0.35 & e0.00 & e 0.28 & $e 0.06$ & e 0.13 & $e 0.83$ \\
\hline 23 & e0.00 & e 0.48 & e0.08 & e0.00 & e 0.00 & e0 0.00 & e0.25 & e0.00 & e0.35 & $\mathrm{e} 0.04$ & e0.08 & e0.75 \\
\hline 24 & $\mathrm{e} 0.00$ & $\mathrm{e} 0.36$ & $\mathrm{e} 0.05$ & $\mathrm{e} 0.00$ & $\mathrm{e} 0.00$ & $\mathrm{e} 0.00$ & e0.18 & $\mathrm{e} 0.00$ & e0.17 & $\mathrm{e} 0.02$ & e0.05 & $\mathrm{e} 0.55$ \\
\hline 25 & $\mathrm{e} 0.00$ & e1.3 & e0.04 & e0.00 & e 0.00 & e 0.00 & e 0.12 & e0.00 & e0.06 & $\mathrm{e} 0.01$ & e0.03 & $e 0.53$ \\
\hline 26 & $\mathrm{e} 0.00$ & $e 0.83$ & $\mathrm{e} 0.00$ & $\mathrm{e} 0.00$ & $\mathrm{e} 0.00$ & e0.00 & e0.08 & $\mathrm{e} 0.00$ & e 0.00 & e 0.00 & e 0.01 & e 0.75 \\
\hline 27 & e0.00 & e 0.45 & e0.00 & e 0.00 & e 0.00 & 0.60 & e0.06 & e0.00 & e 0.00 & $\mathrm{e} 0.00$ & e 0.00 & $\mathrm{e} 0.90$ \\
\hline 28 & e0.00 & e 0.47 & e0.11 & e0.00 & e0.00 & 3.9 & e0.02 & e0.00 & e 0.00 & $\mathrm{e} 0.00$ & e0.00 & $\mathrm{e} 0.86$ \\
\hline 29 & e0.00 & e0.89 & e0.07 & e0.00 & --- & e2. 8 & $\mathrm{e} 0.00$ & e0.00 & e 0.00 & $\mathrm{e} 0.00$ & e0.00 & $\mathrm{e} 0.80$ \\
\hline 30 & e0.05 & 0.89 & e0.06 & e 0.00 & --- & 10 & e0.00 & e0.00 & e 0.00 & e0.00 & e 0.00 & e 4.0 \\
\hline 31 & $\mathrm{e} 0.66$ & --- & $\mathrm{e} 0.05$ & $\mathrm{e} 0.00$ & --- & e7. 3 & --- & $\mathrm{e} 0.00$ & --- & $\mathrm{e} 0.00$ & $\mathrm{e} 0.00$ & --- \\
\hline TOTAL & 1.48 & 17.44 & 21.40 & 0.60 & 9.67 & 24.60 & 53.08 & 0.00 & 0.86 & 4.60 & 17.81 & 28.59 \\
\hline MAX & 0.66 & 5.9 & 3.8 & 0.34 & 8.4 & 10 & 7.1 & 0.00 & 0.35 & 0.73 & 6.3 & 8.1 \\
\hline MIN & 0.00 & 0.00 & 0.00 & 0.00 & 0.00 & 0.00 & 0.00 & 0.00 & 0.00 & 0.00 & 0.00 & 0.00 \\
\hline TOTAL Q & 26.02 & 358.72 & 473.60 & 9.15 & 120.59 & 476.18 & 1328.6 & 1.21 & 62.44 & 207.37 & 441.08 & 1074.80 \\
\hline WTR YR & 2005 & TOTAL 180. & 13 MEAN & 0.49 & 10 MIN & $0.00 \quad$ MED & 0.00 & & & & & \\
\hline
\end{tabular}


Table 18A. Daily-mean loads of total phosphorus during October 1, 2003, to September 30, 2004, Waiakea Stream at Hoaka Road (16700600), Hilo, Hawaii.

\section{STATION NUMBER 16700600 Waiakea Stream at Hoaka Road, Hawai LATITUDE 193940 LONGITUDE 1550720 NAD83 \\ Phosphorus, water, unfiltered, pounds per day WATER YEAR OCTOBER 2003 TO SEPTEMBER 2004 DAILY MEAN VALUES}

\begin{tabular}{|c|c|c|c|c|c|c|c|c|c|c|c|c|}
\hline DAY & OCT & NOV & $\mathrm{DEC}$ & JAN & FEB & MAR & $\mathrm{APR}$ & MAY & JUN & JUL & AUG & SEP \\
\hline 1 & e0.00 & $\mathrm{e} 0.00$ & e1. 60 & $\mathrm{e} 0.01$ & e6.74 & e0.11 & e5. 62 & $\mathrm{e} 0.40$ & $\mathrm{e} 0.16$ & $\mathrm{e} 0.00$ & $\mathrm{e} 0.00$ & $\mathrm{e} 0.00$ \\
\hline 2 & e0.00 & e0.00 & e0.88 & e0.00 & e7.57 & e0.04 & e4.07 & e0.28 & $e 0.06$ & $\mathrm{e} 0.00$ & e 0.00 & $\mathrm{e} 0.00$ \\
\hline 3 & e0.00 & $\mathrm{e} 0.00$ & e1.06 & $\mathrm{e} 0.00$ & e6.57 & $\mathrm{e} 0.03$ & e3.12 & $\mathrm{e} 0.22$ & $\mathrm{e} 0.02$ & $\mathrm{e} 0.00$ & $\mathrm{e} 0.00$ & $\mathrm{e} 0.00$ \\
\hline 4 & e0.00 & $\mathrm{e} 0.00$ & e2. 56 & $\mathrm{e} 0.00$ & e4.39 & $\mathrm{e} 0.02$ & e2.37 & e0.95 & $\mathrm{e} 0.00$ & $\mathrm{e} 0.00$ & $\mathrm{e} 0.00$ & $\mathrm{e} 0.00$ \\
\hline 5 & e0.00 & $\mathrm{e} 0.00$ & e0.95 & $\mathrm{e} 0.00$ & e4.68 & e0.11 & e2.01 & e0.62 & $\mathrm{e} 0.03$ & $\mathrm{e} 0.00$ & $\mathrm{e} 0.00$ & $\mathrm{e} 0.00$ \\
\hline 6 & e0.00 & $\mathrm{e} 0.00$ & e6. 55 & $\mathrm{e} 0.00$ & e6.83 & $\mathrm{e} 0.06$ & e1.46 & $\mathrm{e} 0.22$ & $\mathrm{e} 0.02$ & $\mathrm{e} 0.00$ & $\mathrm{e} 0.00$ & $\mathrm{e} 0.00$ \\
\hline 7 & $e 0.00$ & $\mathrm{e} 0.00$ & e1.36 & e 0.00 & e5. 56 & e0.00 & e1.03 & $\mathrm{e} 0.12$ & $\mathrm{e} 0.00$ & $\mathrm{e} 0.00$ & e0.00 & $\mathrm{e} 0.00$ \\
\hline 8 & e0.00 & $\mathrm{e} 0.00$ & e1.40 & $\mathrm{e} 0.00$ & e3.85 & $\mathrm{e} 0.46$ & $\mathrm{e} 0.74$ & $\mathrm{e} 0.08$ & $\mathrm{e} 0.00$ & $\mathrm{e} 0.00$ & $\mathrm{e} 0.00$ & $\mathrm{e} 0.00$ \\
\hline 9 & e0.00 & $\mathrm{e} 0.00$ & e1.59 & $\mathrm{e} 0.00$ & e1.64 & $\mathrm{e} 0.12$ & $\mathrm{e} 0.65$ & $\mathrm{e} 0.06$ & $\mathrm{e} 0.00$ & $\mathrm{e} 0.00$ & $\mathrm{e} 0.00$ & $\mathrm{e} 0.00$ \\
\hline 10 & $\mathrm{e} 0.00$ & $\mathrm{e} 0.00$ & e6.18 & $\mathrm{e} 0.00$ & e1.25 & $\mathrm{e} 0.02$ & e7.56 & $\mathrm{e} 0.04$ & $\mathrm{e} 0.06$ & $\mathrm{e} 0.00$ & $\mathrm{e} 0.00$ & $\mathrm{e} 0.00$ \\
\hline 11 & $\mathrm{e} 0.00$ & $\mathrm{e} 0.00$ & e7.93 & $\mathrm{e} 0.00$ & e1.05 & $\mathrm{e} 0.00$ & e97.3 & $\mathrm{e} 0.03$ & e1.21 & $\mathrm{e} 0.02$ & $\mathrm{e} 0.00$ & $\mathrm{e} 0.00$ \\
\hline 12 & $\mathrm{e} 0.00$ & $\mathrm{e} 0.01$ & e1.21 & $\mathrm{e} 0.00$ & e0.89 & $\mathrm{e} 0.00$ & e192 & e4. 94 & $\mathrm{e} 0.52$ & $\mathrm{e} 0.00$ & $\mathrm{e} 0.00$ & $\mathrm{e} 0.00$ \\
\hline 13 & $\mathrm{e} 0.00$ & $\mathrm{e} 0.00$ & e0 0.75 & $\mathrm{e} 0.00$ & $\mathrm{e} 0.73$ & $\mathrm{e} 0.04$ & e37.4 & $\mathrm{e} 0.26$ & $\mathrm{e} 0.21$ & $\mathrm{e} 0.00$ & $\mathrm{e} 0.00$ & $\mathrm{e} 0.00$ \\
\hline 14 & $\mathrm{e} 0.00$ & $\mathrm{e} 0.00$ & e0.59 & $\mathrm{e} 0.00$ & $\mathrm{e} 0.56$ & e159 & e22. 6 & $\mathrm{e} 0.16$ & $\mathrm{e} 0.03$ & $\mathrm{e} 0.32$ & $\mathrm{e} 0.00$ & $\mathrm{e} 0.00$ \\
\hline 15 & $\mathrm{e} 0.00$ & $\mathrm{e} 0.01$ & $\mathrm{e} 0.49$ & $\mathrm{e} 0.00$ & $\mathrm{e} 0.40$ & e159 & e14.5 & $\mathrm{e} 0.12$ & $\mathrm{e} 0.02$ & $e 0.03$ & $\mathrm{e} 0.00$ & $\mathrm{e} 0.00$ \\
\hline 16 & $\mathrm{e} 0.00$ & e6.79 & $\mathrm{e} 0.37$ & $\mathrm{e} 0.00$ & $\mathrm{e} 0.30$ & e4.02 & e8. 84 & $\mathrm{e} 0.11$ & $\mathrm{e} 0.01$ & $\mathrm{e} 0.00$ & $\mathrm{e} 0.00$ & $\mathrm{e} 0.00$ \\
\hline 17 & $\mathrm{e} 0.00$ & e2.00 & $\mathrm{e} 0.26$ & $\mathrm{e} 0.00$ & $\mathrm{e} 0.25$ & $\mathrm{e} 2.22$ & e11.0 & e0.09 & $\mathrm{e} 0.00$ & $\mathrm{e} 0.00$ & $\mathrm{e} 0.00$ & $\mathrm{e} 0.00$ \\
\hline 18 & $\mathrm{e} 0.00$ & e1.20 & e0.18 & $\mathrm{e} 0.00$ & $\mathrm{e} 0.17$ & e1.71 & e6.18 & e0.07 & $\mathrm{e} 0.00$ & $\mathrm{e} 0.00$ & $\mathrm{e} 0.00$ & $\mathrm{e} 0.00$ \\
\hline 19 & $\mathrm{e} 0.00$ & e1.09 & e0.11 & $\mathrm{e} 0.00$ & $\mathrm{e} 0.10$ & e1.23 & e4.67 & $\mathrm{e} 0.09$ & $\mathrm{e} 0.00$ & $\mathrm{e} 0.00$ & $\mathrm{e} 0.00$ & $\mathrm{e} 0.00$ \\
\hline 20 & e0.00 & $\mathrm{e} 0.80$ & $\mathrm{e} 0.07$ & e0.00 & $\mathrm{e} 0.05$ & e0.83 & e3.86 & e0.08 & e0.00 & $\mathrm{e} 0.00$ & $\mathrm{e} 0.00$ & $\mathrm{e} 0.00$ \\
\hline 21 & $\mathrm{e} 0.00$ & $\mathrm{e} 0.63$ & $\mathrm{e} 0.04$ & $\mathrm{e} 0.00$ & $\mathrm{e} 0.02$ & e0.55 & e2.78 & $\mathrm{e} 0.02$ & $\mathrm{e} 0.00$ & $\mathrm{e} 0.00$ & $\mathrm{e} 0.00$ & $\mathrm{e} 0.00$ \\
\hline 22 & $\mathrm{e} 0.00$ & $\mathrm{e} 0.51$ & $\mathrm{e} 0.01$ & $\mathrm{e} 0.00$ & $\mathrm{e} 0.00$ & e0.55 & e2.04 & $\mathrm{e} 0.00$ & $\mathrm{e} 0.00$ & $\mathrm{e} 0.00$ & $\mathrm{e} 0.00$ & $\mathrm{e} 0.00$ \\
\hline 23 & e0.00 & e 0.40 & $\mathrm{e} 0.00$ & e0. 30 & $\mathrm{e} 0.00$ & e15.9 & e2. 23 & e0.00 & e0.00 & $\mathrm{e} 0.00$ & e0.00 & $\mathrm{e} 0.00$ \\
\hline 24 & $\mathrm{e} 0.00$ & e0.31 & $\mathrm{e} 0.00$ & e0.09 & $\mathrm{e} 0.00$ & e 40.4 & e1.87 & $\mathrm{e} 0.00$ & $\mathrm{e} 0.00$ & $\mathrm{e} 0.00$ & e0.00 & $\mathrm{e} 0.00$ \\
\hline 25 & $\mathrm{e} 0.00$ & $\mathrm{e} 0.22$ & $\mathrm{e} 0.00$ & e300 & $\mathrm{e} 0.00$ & e13.1 & e1. 57 & $\mathrm{e} 0.00$ & $\mathrm{e} 0.00$ & $\mathrm{e} 0.00$ & $\mathrm{e} 0.00$ & $\mathrm{e} 0.00$ \\
\hline 26 & $\mathrm{e} 0.00$ & e0.15 & $\mathrm{e} 0.00$ & e5. 16 & $\mathrm{e} 0.00$ & e11.8 & e1.08 & $\mathrm{e} 0.03$ & $\mathrm{e} 0.00$ & $\mathrm{e} 0.00$ & $\mathrm{e} 0.00$ & $\mathrm{e} 0.00$ \\
\hline 27 & $\mathrm{e} 0.00$ & $\mathrm{e} 0.10$ & $\mathrm{e} 0.00$ & e0.34 & $\mathrm{e} 0.00$ & e13. 5 & e0 0.87 & $\mathrm{e} 0.36$ & $\mathrm{e} 0.00$ & $\mathrm{e} 0.00$ & $\mathrm{e} 0.00$ & $\mathrm{e} 0.00$ \\
\hline 28 & $\mathrm{e} 0.00$ & $\mathrm{e} 0.06$ & $\mathrm{e} 0.00$ & e0.10 & $\mathrm{e} 2.26$ & e7.51 & $\mathrm{e} 0.73$ & e0.43 & $\mathrm{e} 0.00$ & $\mathrm{e} 0.00$ & $\mathrm{e} 0.00$ & $\mathrm{e} 0.00$ \\
\hline 29 & e0.00 & e6.33 & e2. 87 & e23.9 & $\mathrm{e} 0.57$ & e3.96 & e0.63 & e0.11 & $\mathrm{e} 0.00$ & $\mathrm{e} 0.00$ & e0.00 & $\mathrm{e} 0.00$ \\
\hline 30 & $\mathrm{e} 0.00$ & e13.5 & e0.69 & e8.29 & --- & e10.0 & e0.52 & e0.09 & $\mathrm{e} 0.00$ & $\mathrm{e} 0.00$ & $\mathrm{e} 0.00$ & $\mathrm{e} 0.00$ \\
\hline 31 & $\mathrm{e} 0.00$ & --- & $\mathrm{e} 0.11$ & e19.3 & --- & e36. 8 & --- & $\mathrm{e} 0.42$ & --- & $\mathrm{e} 0.00$ & $\mathrm{e} 0.00$ & --- \\
\hline TOTAL & 0.00 & 34.11 & 39.81 & 357.49 & 56.43 & 483.09 & 441.30 & 10.40 & 2.35 & 0.37 & 0.00 & 0.00 \\
\hline MAX & 0.00 & 13.5 & 7.93 & 300 & 7.57 & 159 & 192 & 4.94 & 1.21 & 0.32 & 0.00 & 0.00 \\
\hline MIN & 0.00 & 0.00 & 0.00 & 0.00 & 0.00 & 0.00 & 0.52 & 0.00 & 0.00 & 0.00 & 0.00 & 0.00 \\
\hline TOTAL Q & 0.00 & 265.77 & 371.41 & 564.37 & 526.08 & 31808.74 & 2454 & 192.44 & 67.04 & 6.33 & 0.04 & 0.00 \\
\hline WTR YR & 2004 & TOTAL 1425 & .35 MEAN & $\mathrm{N} 3.89$ MAX & 300 & MIN 0.00 & MED 0.00 & & & & & \\
\hline
\end{tabular}


Table 18B. Daily-mean loads of total phosphorus during October 1, 2004, to September 30, 2005, Waiakea Stream at Hoaka Road (16700600), Hilo, Hawaii.

\section{STATION NUMBER 16700600 Waiakea Stream at Hoaka Road, Hawaii LATITUDE 193940 LONGITUDE 1550720 NAD83 \\ Phosphorus, water, unfiltered, pounds per day WATER YEAR OCTOBER 2004 TO SEPTEMBER 2005 DAILY MEAN VALUES}

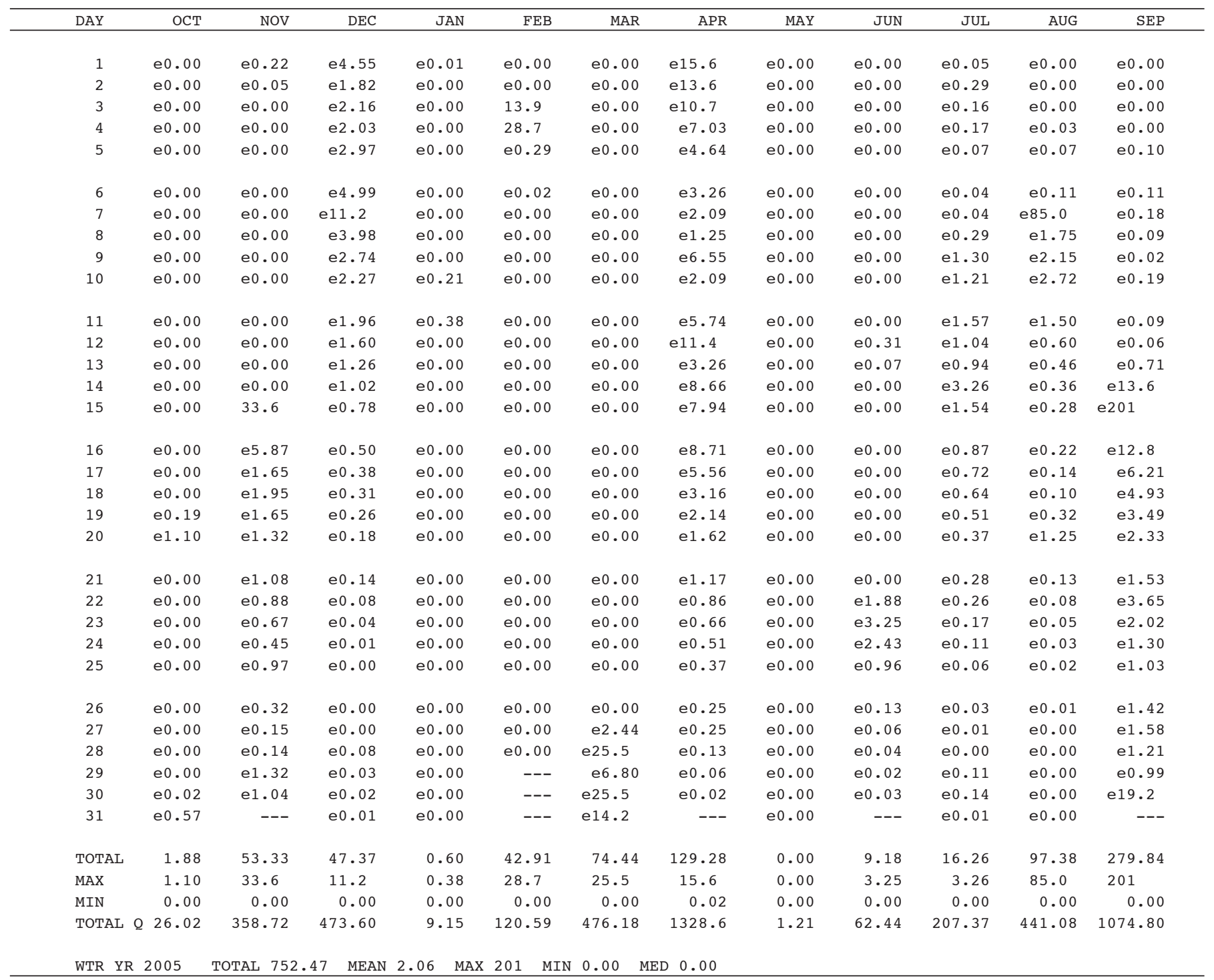


Table 19A. Daily-mean discharge during October 1, 2003, to September 30, 2004, Waiakea Stream at Hoaka Road (16700600), Hilo, Hawaii.

\section{STATION NUMBER 16700600 Waiakea Stream at Hoaka Road, Hawaii LATITUDE 193940 LONGITUDE 1550720 NAD83 \\ Discharge, cubic feet per second WATER YEAR OCTOBER 2003 TO SEPTEMBER 2004 DAILY MEAN VALUES}

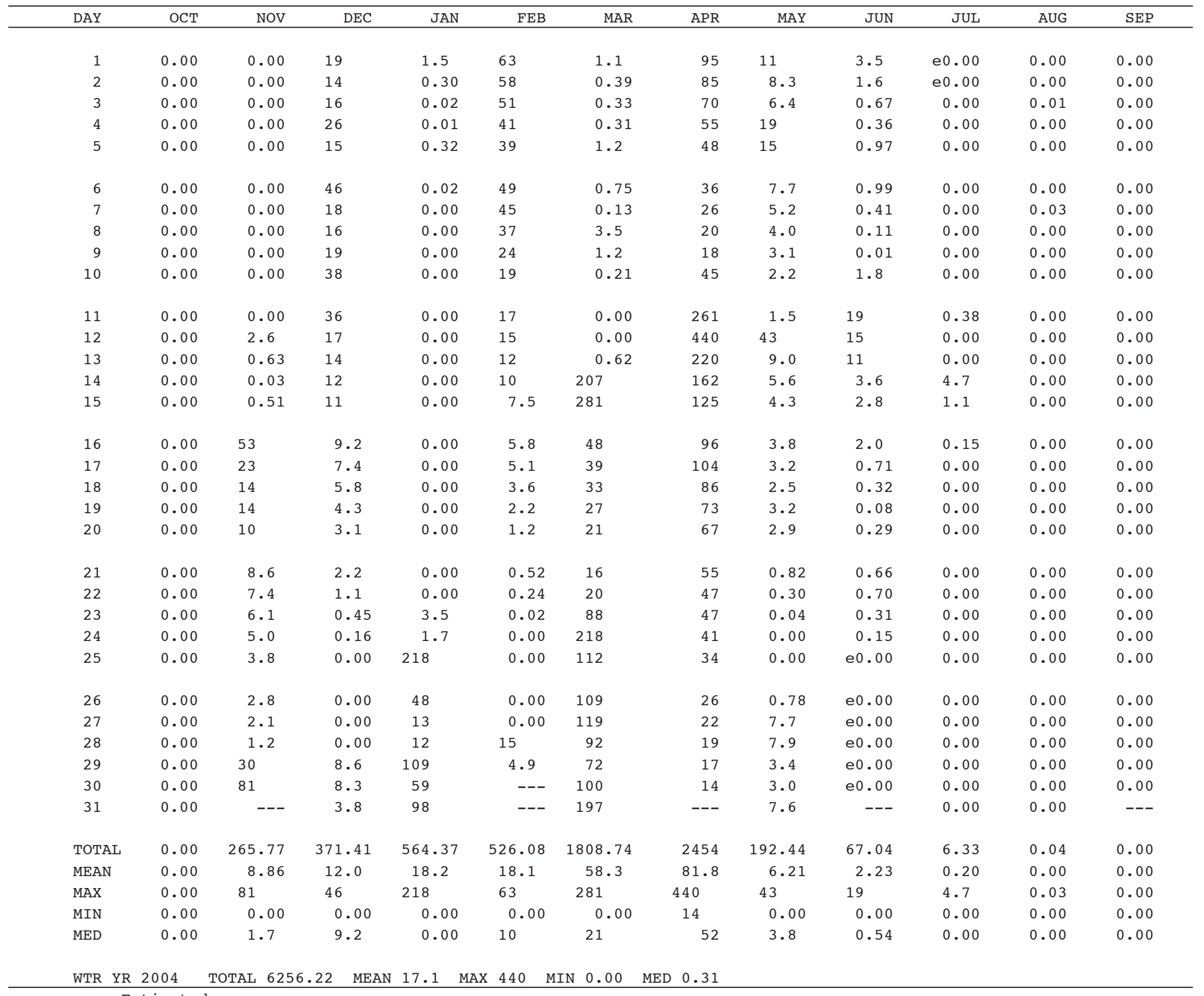


Table 19B. Daily-mean discharge during October 1, 2004, to September 30, 2005, Waiakea Stream at Hoaka Road (16700600), Hilo, Hawaii.

\section{STATION NUMBER 16700600 Waiakea Stream at Hoaka Road, Hawai \\ LATITUDE 193940 LONGITUDE 1550720 NAD83 \\ Discharge, cubic feet per second \\ WATER YEAR OCTOBER 2004 TO SEPTEMBER 2005 \\ DAILY MEAN VALUES}

\begin{tabular}{|c|c|c|c|c|c|c|c|c|c|c|c|c|}
\hline DAY & OCT & NOV & $\mathrm{DEC}$ & JAN & FEB & MAR & $\mathrm{APR}$ & MAY & JUN & JUL & AUG & $\mathrm{SEP}$ \\
\hline 1 & 0.00 & 7.2 & 46 & e 0.20 & 0.00 & 0.00 & 123 & 0.85 & 0.00 & 0.83 & 0.15 & 0.00 \\
\hline 2 & 0.00 & 3.0 & 27 & $\mathrm{e} 0.10$ & 0.00 & 0.00 & 115 & 0.30 & 0.00 & 3.3 & 0.18 & 0.00 \\
\hline 3 & 0.00 & 0.73 & 25 & $\mathrm{e} 0.00$ & 5.2 & 0.00 & 98 & 0.06 & 0.00 & 2.4 & 0.12 & 0.00 \\
\hline 4 & 0.00 & 0.37 & 23 & e 0.00 & 108 & 0.00 & 74 & 0.00 & 0.00 & 2.3 & 0.96 & 0.00 \\
\hline 5 & 0.00 & 0.21 & 28 & e 0.00 & 6.4 & 0.00 & 57 & 0.00 & 0.00 & 1.1 & 2.1 & 2.2 \\
\hline 6 & 0.00 & 0.00 & 34 & e0 0.00 & 0.76 & 0.00 & 48 & 0.00 & 0.00 & 0.72 & 2.0 & 2.8 \\
\hline 7 & 0.00 & 0.00 & 77 & 0.00 & 0.10 & 0.00 & 38 & 0.00 & 0.00 & 0.68 & 180 & 4.6 \\
\hline 8 & 0.00 & 0.00 & 42 & 0.00 & 0.00 & 0.00 & 29 & 0.00 & 0.00 & 3.6 & 29 & 4.1 \\
\hline 9 & 0.00 & 0.00 & 30 & 0.00 & 0.00 & 0.00 & 43 & 0.00 & 0.00 & 16 & 27 & 1.5 \\
\hline 10 & 0.00 & 0.00 & e27 & 1.8 & 0.00 & 0.00 & 35 & 0.00 & 0.22 & 15 & 27 & 4.9 \\
\hline 11 & 0.01 & 0.00 & e23 & 6.7 & 0.00 & 0.01 & 48 & 0.00 & 0.40 & 19 & 26 & 3.2 \\
\hline 12 & 0.01 & 0.00 & e19 & 0.33 & 0.00 & 0.11 & 65 & 0.00 & 6.1 & 14 & 22 & 2.5 \\
\hline 13 & 0.00 & 0.00 & e16 & 0.02 & 0.13 & 0.02 & 40 & 0.00 & 3.0 & 12 & 19 & 13 \\
\hline 14 & 0.00 & 0.01 & e13 & 0.00 & 0.00 & 0.00 & 71 & 0.00 & 0.48 & 28 & 16 & 68 \\
\hline 15 & 0.00 & 114 & e9.0 & 0.00 & 0.00 & 0.00 & 74 & 0.00 & 0.08 & 18 & 14 & 356 \\
\hline 16 & 0.00 & 49 & e7. 3 & 0.00 & 0.00 & 0.00 & 75 & 0.00 & 0.00 & 11 & 12 & 80 \\
\hline 17 & 0.00 & 19 & e6. 2 & 0.00 & 0.00 & 0.00 & 61 & 0.00 & 0.00 & 10 & 9.0 & 58 \\
\hline 18 & 0.00 & 21 & e5. 4 & 0.00 & 0.00 & 0.00 & 47 & 0.00 & 0.00 & 9.5 & 7.3 & 52 \\
\hline 19 & 1.7 & 19 & e4.0 & 0.00 & 0.00 & 0.00 & 38 & 0.00 & 0.00 & 8.3 & 8.1 & 42 \\
\hline 20 & 11 & 17 & e3. 2 & 0.00 & 0.00 & 0.00 & 31 & 0.00 & 0.00 & 6.4 & 18 & 33 \\
\hline 21 & 0.47 & 15 & $\mathrm{e} 2.1$ & 0.00 & 0.00 & 0.00 & 24 & 0.00 & 0.21 & 5.3 & 6.6 & 27 \\
\hline 22 & 0.00 & 13 & $\mathrm{e} 1.2$ & 0.00 & 0.00 & 0.00 & 20 & 0.00 & 10 & 5.3 & 4.2 & 41 \\
\hline 23 & 0.00 & 10 & e 0.50 & 0.00 & 0.00 & 0.00 & 17 & 0.00 & 17 & 3.8 & 3.3 & 35 \\
\hline 24 & 0.00 & 7.3 & $\mathrm{e} 0.20$ & 0.00 & 0.00 & 0.00 & 14 & 0.00 & 13 & 2.9 & 2.6 & 23 \\
\hline 25 & 0.00 & 15 & e0.00 & 0.00 & 0.00 & 0.00 & 11 & 0.00 & 6.9 & 1.7 & 2.1 & 20 \\
\hline 26 & 0.14 & 9.9 & e0.00 & 0.00 & 0.00 & 0.04 & 9.1 & 0.00 & 2.3 & 0.94 & 1.2 & 26 \\
\hline 27 & 0.10 & 5.0 & e2.0 & 0.00 & 0.00 & 13 & 11 & 0.00 & 1.1 & 0.46 & 0.52 & 29 \\
\hline 28 & 0.00 & 4.8 & e1.0 & 0.00 & 0.00 & 130 & 6.7 & 0.00 & 0.72 & 0.20 & 0.32 & 25 \\
\hline 29 & 0.00 & 9.2 & e 0.70 & 0.00 & --- & 69 & 3.8 & 0.00 & 0.41 & 2.0 & 0.29 & 21 \\
\hline 30 & 0.59 & 19 & $\mathrm{e} 0.50$ & 0.00 & --- & 151 & 2.0 & 0.00 & 0.52 & 2.2 & 0.04 & 100 \\
\hline 31 & 12 & --- & $\mathrm{e} 0.30$ & 0.00 & --- & 113 & --- & 0.00 & --- & 0.44 & 0.00 & --- \\
\hline TOTAL & 26.02 & 358.72 & 473.60 & 9.15 & 120.59 & 476.18 & 1328.6 & 1.21 & 62.44 & 207.37 & 441.08 & 1074.80 \\
\hline MEAN & 0.84 & 12.0 & 15.3 & 0.30 & 4.31 & 15.4 & 44.3 & 0.04 & 2.08 & 6.69 & 14.2 & 35.8 \\
\hline MAX & 12 & 114 & 77 & 6.7 & 108 & 151 & 123 & 0.85 & 17 & 28 & 180 & 356 \\
\hline MIN & 0.00 & 0.00 & 0.00 & 0.00 & 0.00 & 0.00 & 2.0 & 0.00 & 0.00 & 0.20 & 0.00 & 0.00 \\
\hline MED & 0.00 & 6.1 & 7.3 & 0.00 & 0.00 & 0.00 & 39 & 0.00 & 0.15 & 3.6 & 4.2 & 22 \\
\hline WTR YR & 2005 & TOTAL 457 & .76 MEAN & $12.5 \quad \operatorname{MAX}$ & 356 MIN & 0.00 & MED 0.46 & & & & & \\
\hline
\end{tabular}


Table 19C. Daily-mean discharge during October 1, 2005, to September 30, 2006, Waiakea Stream at Hoaka Road (16700600), Hilo, Hawaii.

STATION NUMBER 16700600 Waiakea Stream at Hoaka Road, Hawaii

LATITUDE 193940 LONGITUDE 1550720 NAD83

Discharge, cubic feet per second

WATER YEAR OCTOBER 2005 TO SEPTEMBER 2006

DAILY MEAN VALUES

\begin{tabular}{|c|c|c|c|c|c|c|c|c|c|c|c|c|}
\hline DAY & OCT & NOV & DEC & JAN & FEB & MAR & APR & MAY & JUN & JUL & AUG & SEP \\
\hline 1 & 42 & --- & --- & --- & --- & --- & --- & --- & --- & --- & --- & --- \\
\hline 2 & 36 & --- & --- & --- & --- & --- & --- & --- & --- & --- & --- & --- \\
\hline 3 & 41 & --- & --- & --- & --- & --- & --- & --- & --- & --- & --- & --- \\
\hline 4 & 38 & --- & --- & --- & --- & --- & --- & --- & --- & --- & --- & --- \\
\hline 5 & 31 & --- & --- & --- & --- & --- & --- & --- & --- & --- & --- & --- \\
\hline 6 & 32 & --- & --- & --- & --- & --- & --- & --- & --- & --- & --- & --- \\
\hline 7 & 42 & --- & --- & --- & --- & --- & --- & --- & --- & --- & --- & --- \\
\hline 8 & 30 & --- & --- & --- & --- & --- & --- & --- & --- & --- & --- & --- \\
\hline 9 & 24 & --- & --- & --- & --- & --- & --- & --- & --- & --- & --- & --- \\
\hline 10 & 21 & --- & --- & --- & --- & --- & --- & --- & --- & --- & --- & --- \\
\hline 11 & 22 & --- & --- & --- & --- & --- & --- & --- & --- & --- & --- & --- \\
\hline 12 & --- & --- & --- & --- & --- & --- & --- & --- & --- & --- & --- & --- \\
\hline 13 & --- & --- & --- & --- & --- & --- & --- & --- & --- & --- & --- & --- \\
\hline 14 & --- & --- & --- & --- & --- & --- & --- & --- & --- & --- & --- & --- \\
\hline 15 & --- & --- & --- & --- & --- & --- & --- & --- & --- & --- & --- & --- \\
\hline 16 & --- & --- & --- & --- & --- & --- & --- & --- & --- & --- & --- & --- \\
\hline 17 & --- & --- & --- & --- & --- & --- & --- & --- & --- & --- & --- & --- \\
\hline 18 & --- & --- & --- & --- & --- & --- & --- & --- & --- & --- & --- & --- \\
\hline 19 & --- & --- & --- & --- & --- & --- & --- & --- & --- & --- & --- & --- \\
\hline 20 & --- & --- & --- & --- & --- & --- & --- & --- & --- & --- & --- & --- \\
\hline 21 & --- & --- & --- & --- & --- & --- & --- & --- & --- & --- & --- & --- \\
\hline 22 & --- & --- & --- & --- & --- & --- & --- & --- & --- & --- & --- & --- \\
\hline 23 & --- & --- & --- & --- & --- & --- & --- & --- & --- & --- & --- & --- \\
\hline 24 & --- & --- & --- & --- & --- & --- & --- & --- & --- & --- & --- & --- \\
\hline 25 & --- & --- & --- & --- & --- & --- & --- & --- & --- & --- & --- & --- \\
\hline 26 & --- & --- & --- & --- & --- & --- & --- & --- & --- & --- & --- & --- \\
\hline 27 & --- & --- & --- & --- & --- & --- & --- & --- & --- & --- & --- & --- \\
\hline 28 & --- & --- & --- & --- & --- & --- & --- & --- & --- & --- & --- & --- \\
\hline 29 & --- & --- & --- & --- & --- & --- & --- & --- & --- & --- & --- & --- \\
\hline 30 & --- & --- & --- & --- & --- & --- & --- & --- & --- & --- & --- & --- \\
\hline 31 & --- & --- & --- & --- & --- & --- & --- & --- & --- & --- & --- & --- \\
\hline TOTAL & --- & --- & --- & --- & --- & --- & --- & --- & --- & --- & --- & --- \\
\hline MEAN & --- & --- & --- & --- & --- & --- & --- & --- & --- & --- & --- & --- \\
\hline MAX & --- & --- & --- & --- & --- & --- & --- & --- & --- & --- & --- & --- \\
\hline MIN & --- & --- & --- & --- & --- & --- & --- & --- & --- & --- & --- & --- \\
\hline MED & --- & --- & --- & --- & --- & --- & --- & --- & --- & --- & --- & --- \\
\hline
\end{tabular}


Table 20A. Daily-mean loads of suspended sediment during October 1, 2003, to September 30, 2004, Waiakea Stream at Hilo (16701300), Hilo, Hawaii.

\section{STATION NUMBER 16701300 Waiakea Stream at Hilo, Hawaii LATITUDE 194238 LONGITUDE 1550502 OLDHI \\ Suspended sediment discharge, tons per day WATER YEAR OCTOBER 2003 TO SEPTEMBER 2004 DAILY MEAN VALUES}

\begin{tabular}{|c|c|c|c|c|c|c|c|c|c|c|c|c|}
\hline DAY & OCT & NOV & DEC & JAN & FEB & MAR & APR & MAY & JUN & JUL & AUG & SEP \\
\hline 1 & e 0.00 & e0.00 & e0.00 & e 0.00 & e 0.47 & e0 0.00 & e1.0 & e 0.00 & e 0.00 & e 0.00 & e 0.00 & $\mathrm{e} 0.00$ \\
\hline 2 & $\mathrm{e} 0.00$ & $\mathrm{e} 0.00$ & $e 0.00$ & $\mathrm{e} 0.00$ & e0.15 & $\mathrm{e} 0.00$ & e0.42 & $\mathrm{e} 0.00$ & $\mathrm{e} 0.00$ & $\mathrm{e} 0.00$ & $\mathrm{e} 0.00$ & $\mathrm{e} 0.00$ \\
\hline 3 & $\mathrm{e} 0.00$ & $\mathrm{e} 0.00$ & e0.00 & $\mathrm{e} 0.00$ & $\mathrm{e} 0.03$ & $\mathrm{e} 0.00$ & $\mathrm{e} 0.17$ & $\mathrm{e} 0.00$ & $\mathrm{e} 0.00$ & $\mathrm{e} 0.00$ & $\mathrm{e} 0.00$ & $\mathrm{e} 0.00$ \\
\hline 4 & e 0.00 & e0.00 & e0.00 & e 0.00 & e0 0.00 & e0.00 & e0.03 & e 0.00 & e 0.00 & e 0.00 & e 0.00 & $\mathrm{e} 0.00$ \\
\hline 5 & $\mathrm{e} 0.00$ & $\mathrm{e} 0.00$ & $e 0.00$ & e 0.00 & e 0.00 & e 0.00 & $\mathrm{e} 0.00$ & e 0.00 & e 0.00 & e 0.00 & $\mathrm{e} 0.00$ & $\mathrm{e} 0.00$ \\
\hline 6 & e 0.00 & e 0.00 & e0.00 & e 0.00 & $e 0.06$ & e0.00 & e 0.00 & e 0.00 & e 0.00 & e 0.00 & e 0.00 & $\mathrm{e} 0.00$ \\
\hline 7 & e 0.00 & e 0.00 & e0.00 & e 0.00 & $e 0.03$ & e0.00 & e0 0.00 & e 0.00 & e 0.00 & e 0.00 & e 0.00 & $\mathrm{e} 0.00$ \\
\hline 8 & $\mathrm{e} 0.00$ & $\mathrm{e} 0.00$ & e0.00 & $\mathrm{e} 0.00$ & $\mathrm{e} 0.02$ & $\mathrm{e} 0.00$ & e0.00 & $\mathrm{e} 0.00$ & $\mathrm{e} 0.00$ & $\mathrm{e} 0.00$ & $\mathrm{e} 0.00$ & $\mathrm{e} 0.00$ \\
\hline 9 & $\mathrm{e} 0.00$ & $\mathrm{e} 0.00$ & e0.00 & $\mathrm{e} 0.00$ & $\mathrm{e} 0.00$ & $\mathrm{e} 0.00$ & e0.00 & $\mathrm{e} 0.00$ & $\mathrm{e} 0.00$ & $\mathrm{e} 0.00$ & $\mathrm{e} 0.00$ & $\mathrm{e} 0.00$ \\
\hline 10 & $\mathrm{e} 0.00$ & e 0.00 & e0.00 & e0.00 & $\mathrm{e} 0.00$ & $\mathrm{e} 0.00$ & $\mathrm{e} 0.06$ & $\mathrm{e} 0.00$ & $\mathrm{e} 0.00$ & $\mathrm{e} 0.00$ & $\mathrm{e} 0.00$ & $\mathrm{e} 0.00$ \\
\hline 11 & $\mathrm{e} 0.00$ & $\mathrm{e} 0.00$ & $e 0.00$ & $\mathrm{e} 0.00$ & $\mathrm{e} 0.00$ & $\mathrm{e} 0.00$ & e7. 4 & $\mathrm{e} 0.00$ & $\mathrm{e} 0.00$ & $\mathrm{e} 0.00$ & $\mathrm{e} 0.00$ & $\mathrm{e} 0.00$ \\
\hline 12 & e 0.00 & e0.00 & $e 0.00$ & e0.00 & $\mathrm{e} 0.00$ & $\mathrm{e} 0.00$ & 27 & e 0.02 & e 0.00 & e 0.00 & e 0.00 & $\mathrm{e} 0.00$ \\
\hline 13 & e 0.00 & e0.00 & $e 0.00$ & e0.00 & e 0.00 & $\mathrm{e} 0.00$ & e5. 9 & e 0.00 & e 0.00 & e 0.00 & e 0.00 & $\mathrm{e} 0.00$ \\
\hline 14 & e 0.00 & $\mathrm{e} 0.00$ & e0.00 & $\mathrm{e} 0.00$ & $\mathrm{e} 0.00$ & 12 & e 3.0 & $\mathrm{e} 0.00$ & $\mathrm{e} 0.00$ & e0.00 & $\mathrm{e} 0.00$ & $\mathrm{e} 0.00$ \\
\hline 15 & $\mathrm{e} 0.00$ & $\mathrm{e} 0.00$ & e0.00 & e0.00 & e 0.00 & 17 & e1. 6 & $\mathrm{e} 0.00$ & $\mathrm{e} 0.00$ & $\mathrm{e} 0.00$ & $\mathrm{e} 0.00$ & $\mathrm{e} 0.00$ \\
\hline 16 & e 0.00 & $\mathrm{e} 0.00$ & e0.00 & e0.00 & e 0.00 & e0.05 & e0.76 & e 0.00 & e 0.00 & e 0.00 & e 0.00 & $\mathrm{e} 0.00$ \\
\hline 17 & e 0.00 & $\mathrm{e} 0.00$ & e0.00 & e0.00 & e 0.00 & $\mathrm{e} 0.00$ & e1. 5 & e 0.00 & e 0.00 & e 0.00 & e 0.00 & $\mathrm{e} 0.00$ \\
\hline 18 & $\mathrm{e} 0.00$ & $\mathrm{e} 0.00$ & $e 0.00$ & $\mathrm{e} 0.00$ & $\mathrm{e} 0.00$ & $\mathrm{e} 0.00$ & e0.89 & $\mathrm{e} 0.00$ & $\mathrm{e} 0.00$ & $\mathrm{e} 0.00$ & $\mathrm{e} 0.00$ & $\mathrm{e} 0.00$ \\
\hline 19 & $\mathrm{e} 0.00$ & e 0.00 & $e 0.00$ & e 0.00 & e 0.00 & e0.00 & e0.35 & e 0.00 & e 0.00 & e 0.00 & e 0.00 & $\mathrm{e} 0.00$ \\
\hline 20 & $\mathrm{e} 0.00$ & $\mathrm{e} 0.00$ & $e 0.00$ & $\mathrm{e} 0.00$ & $\mathrm{e} 0.00$ & $\mathrm{e} 0.00$ & e0.19 & e 0.00 & e 0.00 & e 0.00 & e 0.00 & $\mathrm{e} 0.00$ \\
\hline 21 & $\mathrm{e} 0.00$ & $\mathrm{e} 0.00$ & $e 0.00$ & $\mathrm{e} 0.00$ & $\mathrm{e} 0.00$ & $\mathrm{e} 0.00$ & e0.06 & $\mathrm{e} 0.00$ & $\mathrm{e} 0.00$ & $\mathrm{e} 0.00$ & $\mathrm{e} 0.00$ & $\mathrm{e} 0.00$ \\
\hline 22 & e 0.00 & $\mathrm{e} 0.00$ & $e 0.00$ & e0.00 & e 0.00 & e0.00 & e0.00 & e 0.00 & e 0.00 & e 0.00 & e 0.00 & $\mathrm{e} 0.00$ \\
\hline 23 & e 0.00 & $\mathrm{e} 0.00$ & e0.00 & e0.00 & e 0.00 & 1.1 & e0 0.00 & e 0.00 & e 0.00 & e 0.00 & e 0.00 & $\mathrm{e} 0.00$ \\
\hline 24 & $\mathrm{e} 0.00$ & $\mathrm{e} 0.00$ & $e 0.00$ & $\mathrm{e} 0.00$ & $\mathrm{e} 0.00$ & 4.8 & $\mathrm{e} 0.00$ & $\mathrm{e} 0.00$ & $\mathrm{e} 0.00$ & $\mathrm{e} 0.00$ & $\mathrm{e} 0.00$ & $\mathrm{e} 0.00$ \\
\hline 25 & e 0.00 & $\mathrm{e} 0.00$ & $e 0.00$ & e13 & e 0.00 & e 0.74 & e0.00 & e 0.00 & e 0.00 & e 0.00 & e 0.00 & $\mathrm{e} 0.00$ \\
\hline 26 & $\mathrm{e} 0.00$ & e 0.00 & $e 0.00$ & e2. 2 & $\mathrm{e} 0.00$ & e0.55 & $\mathrm{e} 0.00$ & $\mathrm{e} 0.00$ & e 0.00 & $\mathrm{e} 0.00$ & e 0.00 & $\mathrm{e} 0.00$ \\
\hline 27 & $\mathrm{e} 0.00$ & e0.00 & $e 0.00$ & e 0.00 & e 0.00 & e0.66 & $\mathrm{e} 0.00$ & $\mathrm{e} 0.00$ & e 0.00 & e 0.00 & e 0.00 & $\mathrm{e} 0.00$ \\
\hline 28 & e 0.00 & e 0.00 & $e 0.00$ & e0.00 & e 0.00 & e0.56 & e0.00 & e 0.00 & e 0.00 & e 0.00 & e 0.00 & $\mathrm{e} 0.00$ \\
\hline 29 & e 0.00 & e 0.00 & $e 0.00$ & e1. 6 & e 0.00 & e0.30 & e0.00 & e 0.00 & e 0.00 & e 0.00 & e 0.00 & $\mathrm{e} 0.00$ \\
\hline 30 & e 0.00 & e 0.10 & e0.00 & e0.38 & --- & e0.58 & e0.00 & e 0.00 & e 0.00 & e 0.00 & e 0.00 & $\mathrm{e} 0.00$ \\
\hline 31 & e 0.00 & --- & $e 0.00$ & e1. 4 & --- & e5. 4 & --- & $\mathrm{e} 0.00$ & --- & $\mathrm{e} 0.00$ & $\mathrm{e} 0.00$ & --- \\
\hline TOTAL & 0.00 & 0.10 & 0.00 & 18.58 & 0.76 & 43.74 & 50.33 & 0.02 & 0.00 & 0.00 & 0.00 & 0.00 \\
\hline MAX & 0.00 & 0.10 & 0.00 & 13 & 0.47 & 17 & 27 & 0.02 & 0.00 & 0.00 & 0.00 & 0.00 \\
\hline MIN & 0.00 & 0.00 & 0.00 & 0.00 & 0.00 & 0.00 & 0.00 & 0.00 & 0.00 & 0.00 & 0.00 & 0.00 \\
\hline TOTAL Q & 0.00 & 5.10 & 0.00 & 271.00 & 49.60 & 953.99 & 1230.85 & 3.60 & 0.00 & 0.00 & 0.00 & 0.00 \\
\hline WTR YR & 2004 & TOTAL 113.53 & 3 MEAN & 0.31 MAX & 27 MIN & $0.00 \quad$ MED & 0.00 & & & & & \\
\hline
\end{tabular}


Table 20B. Daily-mean loads of suspended sediment during October 1, 2004, to September 30, 2005, Waiakea Stream at Hilo (16701300), Hilo, Hawaii.

\section{STATION NUMBER 16701300 Waiakea Stream at Hilo, Hawaii LATITUDE 194238 LONGITUDE 1550502 OLDHI \\ Suspended sediment discharge, tons per day WATER YEAR OCTOBER 2004 TO SEPTEMBER 2005 DAILY MEAN VALUES}

\begin{tabular}{|c|c|c|c|c|c|c|c|c|c|c|c|c|}
\hline DAY & OCT & NOV & $\mathrm{DEC}$ & JAN & FEB & MAR & APR & MAY & JUN & JUL & AUG & SEP \\
\hline 1 & $\mathrm{e} 0.00$ & $\mathrm{e} 0.00$ & $\mathrm{e} 0.00$ & $\mathrm{e} 0.00$ & $\mathrm{e} 0.00$ & $\mathrm{e} 0.00$ & e3.0 & $\mathrm{e} 0.00$ & $\mathrm{e} 0.00$ & $\mathrm{e} 0.00$ & $\mathrm{e} 0.00$ & e0.00 \\
\hline 2 & $\mathrm{e} 0.00$ & $\mathrm{e} 0.00$ & e0.00 & e0.00 & $\mathrm{e} 0.00$ & e0.00 & e2. 8 & $\mathrm{e} 0.00$ & $\mathrm{e} 0.00$ & $\mathrm{e} 0.00$ & $\mathrm{e} 0.00$ & e0.00 \\
\hline 3 & $\mathrm{e} 0.00$ & $\mathrm{e} 0.00$ & $\mathrm{e} 0.00$ & $\mathrm{e} 0.00$ & $\mathrm{e} 0.00$ & $\mathrm{e} 0.00$ & $\mathrm{e} 0.38$ & $\mathrm{e} 0.00$ & $\mathrm{e} 0.00$ & $\mathrm{e} 0.00$ & $\mathrm{e} 0.00$ & e0.00 \\
\hline 4 & $\mathrm{e} 0.00$ & $\mathrm{e} 0.00$ & $\mathrm{e} 0.00$ & $\mathrm{e} 0.00$ & $\mathrm{e} 0.37$ & $\mathrm{e} 0.00$ & $\mathrm{e} 0.00$ & $\mathrm{e} 0.00$ & $\mathrm{e} 0.00$ & $\mathrm{e} 0.00$ & $\mathrm{e} 0.00$ & e0.00 \\
\hline 5 & $\mathrm{e} 0.00$ & $\mathrm{e} 0.00$ & $\mathrm{e} 0.00$ & e0.00 & $\mathrm{e} 0.00$ & $\mathrm{e} 0.00$ & $\mathrm{e} 0.00$ & $\mathrm{e} 0.00$ & $\mathrm{e} 0.00$ & $\mathrm{e} 0.00$ & $\mathrm{e} 0.00$ & e0.00 \\
\hline 6 & $\mathrm{e} 0.00$ & $\mathrm{e} 0.00$ & $\mathrm{e} 0.00$ & $\mathrm{e} 0.00$ & $\mathrm{e} 0.00$ & $\mathrm{e} 0.00$ & $\mathrm{e} 0.00$ & $\mathrm{e} 0.00$ & $\mathrm{e} 0.00$ & $\mathrm{e} 0.00$ & $\mathrm{e} 0.00$ & e 0.00 \\
\hline 7 & $\mathrm{e} 0.00$ & $\mathrm{e} 0.00$ & $\mathrm{e} 0.00$ & $\mathrm{e} 0.00$ & $\mathrm{e} 0.00$ & $\mathrm{e} 0.00$ & $\mathrm{e} 0.00$ & $\mathrm{e} 0.00$ & $\mathrm{e} 0.00$ & $\mathrm{e} 0.00$ & 133 & e 0.00 \\
\hline 8 & $\mathrm{e} 0.00$ & $\mathrm{e} 0.00$ & $\mathrm{e} 0.00$ & $\mathrm{e} 0.00$ & $\mathrm{e} 0.00$ & $\mathrm{e} 0.00$ & $\mathrm{e} 0.00$ & $\mathrm{e} 0.00$ & $\mathrm{e} 0.00$ & $\mathrm{e} 0.00$ & e1.3 & $\mathrm{e} 0.00$ \\
\hline 9 & $\mathrm{e} 0.00$ & $\mathrm{e} 0.00$ & $\mathrm{e} 0.00$ & $\mathrm{e} 0.00$ & $\mathrm{e} 0.00$ & $\mathrm{e} 0.00$ & $\mathrm{e} 0.00$ & $\mathrm{e} 0.00$ & $\mathrm{e} 0.00$ & $\mathrm{e} 0.00$ & $\mathrm{e} 0.00$ & $\mathrm{e} 0.00$ \\
\hline 10 & $\mathrm{e} 0.00$ & $\mathrm{e} 0.00$ & $\mathrm{e} 0.00$ & $\mathrm{e} 0.00$ & $\mathrm{e} 0.00$ & $\mathrm{e} 0.00$ & $\mathrm{e} 0.00$ & $\mathrm{e} 0.00$ & $\mathrm{e} 0.00$ & $\mathrm{e} 0.00$ & $\mathrm{e} 0.00$ & e 0.00 \\
\hline 11 & $\mathrm{e} 0.00$ & $\mathrm{e} 0.00$ & $\mathrm{e} 0.00$ & $\mathrm{e} 0.00$ & $\mathrm{e} 0.00$ & $\mathrm{e} 0.00$ & $\mathrm{e} 0.00$ & $\mathrm{e} 0.00$ & $\mathrm{e} 0.00$ & $\mathrm{e} 0.00$ & $\mathrm{e} 0.00$ & e0.00 \\
\hline 12 & e0.00 & e0.00 & e0.00 & e0.00 & $\mathrm{e} 0.00$ & e0.00 & e0.03 & $\mathrm{e} 0.00$ & $\mathrm{e} 0.00$ & $\mathrm{e} 0.00$ & $\mathrm{e} 0.00$ & e0.00 \\
\hline 13 & e0.00 & $\mathrm{e} 0.00$ & e0.00 & e0.00 & $\mathrm{e} 0.00$ & e0.00 & $\mathrm{e} 0.00$ & $\mathrm{e} 0.00$ & $\mathrm{e} 0.00$ & $\mathrm{e} 0.00$ & $\mathrm{e} 0.00$ & e0.00 \\
\hline 14 & $\mathrm{e} 0.00$ & $\mathrm{e} 0.00$ & $\mathrm{e} 0.00$ & $\mathrm{e} 0.00$ & $\mathrm{e} 0.00$ & $\mathrm{e} 0.00$ & $\mathrm{e} 0.00$ & $\mathrm{e} 0.00$ & $\mathrm{e} 0.00$ & $\mathrm{e} 0.00$ & $\mathrm{e} 0.00$ & e0.13 \\
\hline 15 & e 0.00 & $\mathrm{e} 0.00$ & e0.00 & e0.00 & $\mathrm{e} 0.00$ & $\mathrm{e} 0.00$ & e0.03 & $e 0.00$ & $\mathrm{e} 0.00$ & $e 0.00$ & e0.00 & e468 \\
\hline 16 & $\mathrm{e} 0.00$ & $\mathrm{e} 0.00$ & $\mathrm{e} 0.00$ & $\mathrm{e} 0.00$ & $\mathrm{e} 0.00$ & $\mathrm{e} 0.00$ & $\mathrm{e} 0.18$ & $\mathrm{e} 0.00$ & $\mathrm{e} 0.00$ & $\mathrm{e} 0.00$ & $\mathrm{e} 0.00$ & e26 \\
\hline 17 & $\mathrm{e} 0.00$ & $\mathrm{e} 0.00$ & $\mathrm{e} 0.00$ & $\mathrm{e} 0.00$ & $\mathrm{e} 0.00$ & $\mathrm{e} 0.00$ & $\mathrm{e} 0.00$ & $\mathrm{e} 0.00$ & $\mathrm{e} 0.00$ & $\mathrm{e} 0.00$ & $\mathrm{e} 0.00$ & e3.7 \\
\hline 18 & $\mathrm{e} 0.00$ & $\mathrm{e} 0.00$ & $\mathrm{e} 0.00$ & $\mathrm{e} 0.00$ & $\mathrm{e} 0.00$ & $\mathrm{e} 0.00$ & $\mathrm{e} 0.00$ & $\mathrm{e} 0.00$ & $\mathrm{e} 0.00$ & $\mathrm{e} 0.00$ & $\mathrm{e} 0.00$ & e1. 8 \\
\hline 19 & $\mathrm{e} 0.00$ & e0.00 & $\mathrm{e} 0.00$ & $\mathrm{e} 0.00$ & $\mathrm{e} 0.00$ & e0.00 & $\mathrm{e} 0.00$ & $\mathrm{e} 0.00$ & e0.00 & $\mathrm{e} 0.00$ & $\mathrm{e} 0.00$ & e0.36 \\
\hline 20 & $\mathrm{e} 0.00$ & $\mathrm{e} 0.00$ & $\mathrm{e} 0.00$ & $\mathrm{e} 0.00$ & $\mathrm{e} 0.00$ & $\mathrm{e} 0.00$ & $\mathrm{e} 0.00$ & $\mathrm{e} 0.00$ & $\mathrm{e} 0.00$ & $\mathrm{e} 0.00$ & $\mathrm{e} 0.00$ & e0.00 \\
\hline 21 & $\mathrm{e} 0.00$ & $\mathrm{e} 0.00$ & $\mathrm{e} 0.00$ & $\mathrm{e} 0.00$ & $\mathrm{e} 0.00$ & $\mathrm{e} 0.00$ & $\mathrm{e} 0.00$ & $\mathrm{e} 0.00$ & $\mathrm{e} 0.00$ & $\mathrm{e} 0.00$ & $\mathrm{e} 0.00$ & $\mathrm{e} 0.00$ \\
\hline 22 & e0.00 & e0.00 & e0.00 & e0.00 & e0.00 & e0.00 & $\mathrm{e} 0.00$ & e0.00 & $\mathrm{e} 0.00$ & $\mathrm{e} 0.00$ & $\mathrm{e} 0.00$ & e0.53 \\
\hline 23 & $\mathrm{e} 0.00$ & $\mathrm{e} 0.00$ & $\mathrm{e} 0.00$ & $\mathrm{e} 0.00$ & $\mathrm{e} 0.00$ & $\mathrm{e} 0.00$ & $\mathrm{e} 0.00$ & $\mathrm{e} 0.00$ & $\mathrm{e} 0.00$ & $\mathrm{e} 0.00$ & $\mathrm{e} 0.00$ & e0.04 \\
\hline 24 & $\mathrm{e} 0.00$ & e0.00 & e0.00 & e0.00 & e0.00 & $\mathrm{e} 0.00$ & $\mathrm{e} 0.00$ & $\mathrm{e} 0.00$ & $\mathrm{e} 0.00$ & $\mathrm{e} 0.00$ & $\mathrm{e} 0.00$ & e0.00 \\
\hline 25 & e0.00 & e 0.00 & e0.00 & e0.00 & e0.00 & e0.00 & $\mathrm{e} 0.00$ & e0.00 & $\mathrm{e} 0.00$ & $\mathrm{e} 0.00$ & $\mathrm{e} 0.00$ & e0.00 \\
\hline 26 & e0.00 & e0.00 & e0.00 & e0.00 & e0.00 & e0.00 & $\mathrm{e} 0.00$ & e0.00 & $\mathrm{e} 0.00$ & $\mathrm{e} 0.00$ & $\mathrm{e} 0.00$ & e0.00 \\
\hline 27 & e0.00 & e0.00 & e0.00 & e0.00 & e0.00 & e 0.00 & $\mathrm{e} 0.00$ & e0.00 & e0.00 & e 0.00 & $\mathrm{e} 0.00$ & e 0.00 \\
\hline 28 & e0.00 & e0.00 & e0.00 & e0.00 & e0.00 & 0.55 & $\mathrm{e} 0.00$ & e0.00 & $\mathrm{e} 0.00$ & e0.00 & $\mathrm{e} 0.00$ & e0.00 \\
\hline 29 & e0.00 & e0.00 & e0.00 & e0.00 & --- & e0.00 & $\mathrm{e} 0.00$ & e0.00 & $\mathrm{e} 0.00$ & e0.00 & $\mathrm{e} 0.00$ & e0.00 \\
\hline 30 & $\mathrm{e} 0.00$ & $\mathrm{e} 0.00$ & e0.00 & $\mathrm{e} 0.00$ & --- & 2.7 & $\mathrm{e} 0.00$ & $\mathrm{e} 0.00$ & $\mathrm{e} 0.00$ & $\mathrm{e} 0.00$ & $\mathrm{e} 0.00$ & e53 \\
\hline 31 & $\mathrm{e} 0.00$ & --- & e0.00 & e0.00 & --- & e2. 3 & --- & $\mathrm{e} 0.00$ & --- & $\mathrm{e} 0.00$ & e0.00 & --- \\
\hline TOTAL & 0.00 & 0.00 & 0.00 & 0.00 & 0.37 & 5.55 & 6.42 & 0.00 & 0.00 & 0.00 & 134.30 & 553.56 \\
\hline MAX & 0.00 & 0.00 & 0.00 & 0.00 & 0.37 & 2.7 & 3.0 & 0.00 & 0.00 & 0.00 & 133 & 468 \\
\hline MIN & 0.00 & 0.00 & 0.00 & 0.00 & 0.00 & 0.00 & 0.00 & 0.00 & 0.00 & 0.00 & 0.00 & 0.00 \\
\hline TOTAL Q & 0.01 & 0.00 & 0.00 & 0.00 & 18.00 & 63.40 & 62.87 & 0.00 & 0.00 & 0.43 & 81.20 & 401.74 \\
\hline WTR YR & 2005 & TOTAL 700.20 & MEAN & 1.9 MAX & 468 MIN & 0.00 MED & 0.00 & & & & & \\
\hline
\end{tabular}


Table 21A. Daily-mean loads of total nitrogen during October 1, 2003, to September 30, 2004, Waiakea Stream at Hilo (16701300), Hilo, Hawaii.

\section{STATION NUMBER 16701300 Waiakea Stream at Hilo, Hawaii LATITUDE 194238 LONGITUDE 1550502 OLDHI \\ Total nitrogen, water, unfiltered, pounds per day WATER YEAR OCTOBER 2003 TO SEPTEMBER 2004 DAILY MEAN VALUES}

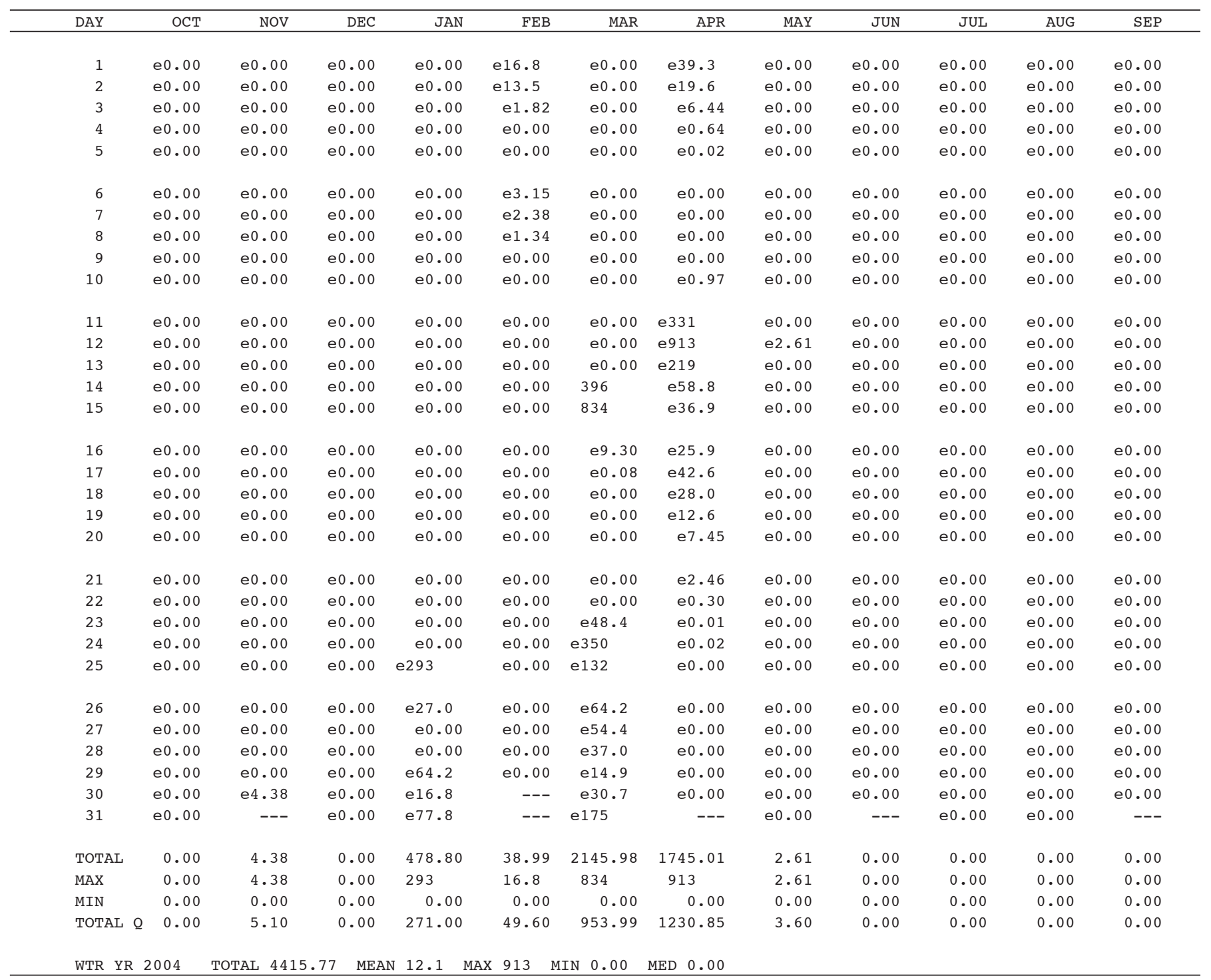


Table 21B. Daily-mean loads of total nitrogen during October 1, 2004, to September 30, 2005, Waiakea Stream at Hilo (16701300), Hilo, Hawaii.

\section{STATION NUMBER 16701300 Waiakea Stream at Hilo, Hawaii LATITUDE 194238 LONGITUDE 1550502 OLDHI \\ Total nitrogen, water, unfiltered, pounds per day WATER YEAR OCTOBER 2004 TO SEPTEMBER 2005 DAILY MEAN VALUES}

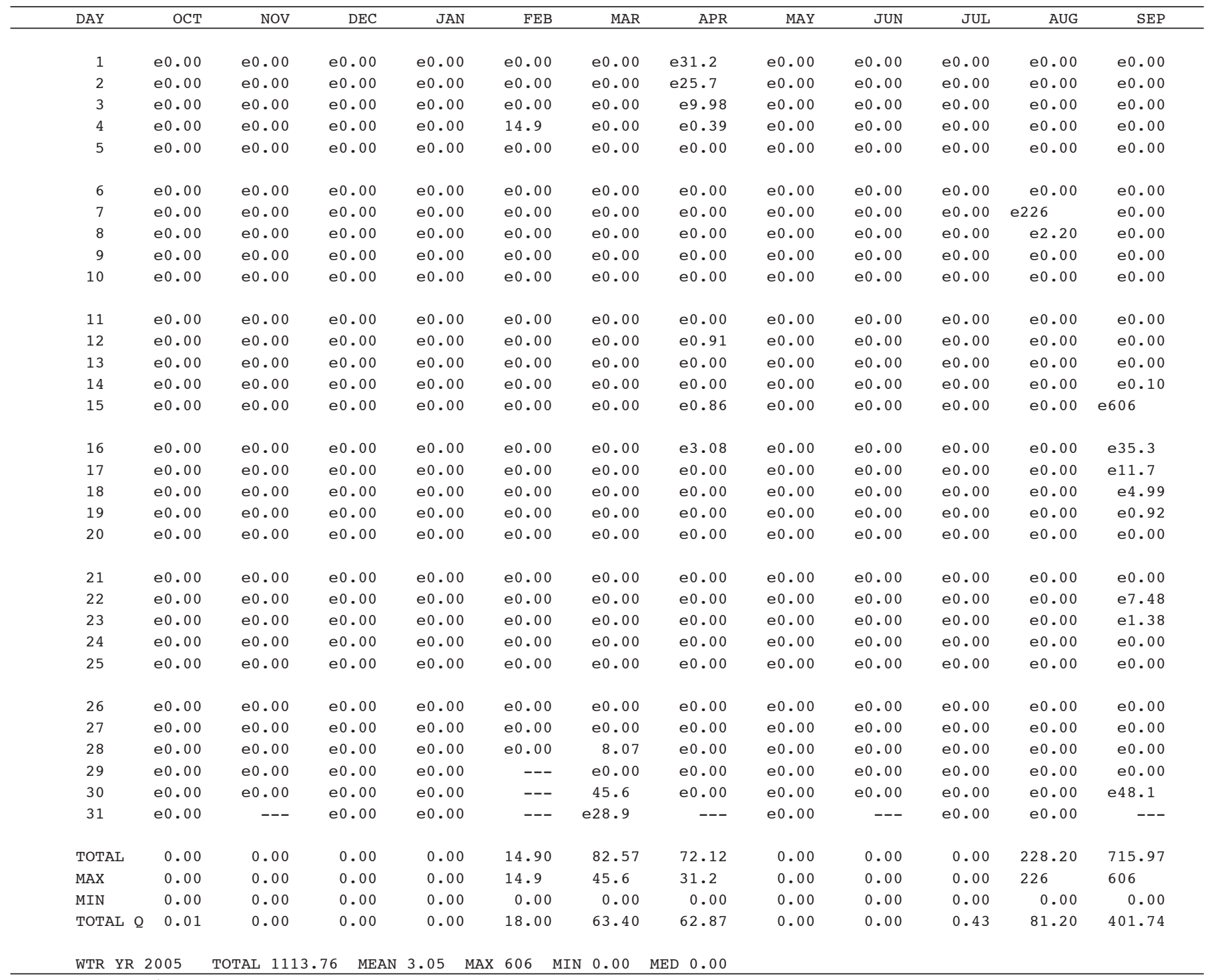


Table 22A. Daily-mean loads of nitrogen, nitrite plus nitrate, dissolved, during October 1, 2003, to September 30, 2004, Waiakea Stream at Hilo (16701300), Hilo, Hawaii.

\section{STATION NUMBER 16701300 Waiakea Stream at Hilo, Hawaii LATITUDE 194238 LONGITUDE 1550502 OLDHI \\ Nitrogen, nitrite + nitrate, dissolved, lbs/day as $\mathbf{N}$ WATER YEAR OCTOBER 2003 TO SEPTEMBER 2004 DAILY MEAN VALUES}

\begin{tabular}{|c|c|c|c|c|c|c|c|c|c|c|c|c|}
\hline DAY & $\mathrm{OCT}$ & NOV & DEC & JAN & FEB & MAR & APR & MAY & JUN & JUL & AUG & SEP \\
\hline 1 & e 0.00 & e 0.00 & e0.00 & e 0.00 & e0.37 & e0.00 & e3. 2 & e 0.00 & $\mathrm{e} 0.00$ & e 0.00 & e 0.00 & $\mathrm{e} 0.00$ \\
\hline 2 & $\mathrm{e} 0.00$ & e 0.00 & $\mathrm{e} 0.00$ & $\mathrm{e} 0.00$ & e0.32 & $\mathrm{e} 0.00$ & e2.9 & $\mathrm{e} 0.00$ & $\mathrm{e} 0.00$ & $\mathrm{e} 0.00$ & $\mathrm{e} 0.00$ & $\mathrm{e} 0.00$ \\
\hline 3 & $\mathrm{e} 0.00$ & $\mathrm{e} 0.00$ & $\mathrm{e} 0.00$ & $\mathrm{e} 0.00$ & $\mathrm{e} 0.05$ & $\mathrm{e} 0.00$ & $\mathrm{e} 2.0$ & $\mathrm{e} 0.00$ & $\mathrm{e} 0.00$ & $\mathrm{e} 0.00$ & $\mathrm{e} 0.00$ & $\mathrm{e} 0.00$ \\
\hline 4 & $\mathrm{e} 0.00$ & e 0.00 & e0.00 & e 0.00 & e0 0.00 & e0.00 & e0.70 & e 0.00 & e0.00 & e 0.00 & e 0.00 & $\mathrm{e} 0.00$ \\
\hline 5 & e 0.00 & $\mathrm{e} 0.00$ & $\mathrm{e} 0.00$ & e 0.00 & $\mathrm{e} 0.00$ & e 0.00 & e0.09 & e 0.00 & e 0.00 & e 0.00 & e 0.00 & $\mathrm{e} 0.00$ \\
\hline 6 & $\mathrm{e} 0.00$ & e 0.00 & e 0.00 & e0 0.00 & e0.06 & e0.00 & e0.00 & e 0.00 & e0.00 & e 0.00 & e 0.00 & $\mathrm{e} 0.00$ \\
\hline 7 & $\mathrm{e} 0.00$ & e 0.00 & e 0.00 & e 0.00 & e 0.12 & e0.00 & e0.00 & e 0.00 & e0.00 & e 0.00 & e 0.00 & $\mathrm{e} 0.00$ \\
\hline 8 & $\mathrm{e} 0.00$ & $\mathrm{e} 0.00$ & $\mathrm{e} 0.00$ & $\mathrm{e} 0.00$ & $\mathrm{e} 0.10$ & $\mathrm{e} 0.00$ & $\mathrm{e} 0.00$ & $\mathrm{e} 0.00$ & $\mathrm{e} 0.00$ & $\mathrm{e} 0.00$ & $\mathrm{e} 0.00$ & $\mathrm{e} 0.00$ \\
\hline 9 & $\mathrm{e} 0.00$ & $\mathrm{e} 0.00$ & $\mathrm{e} 0.00$ & $\mathrm{e} 0.00$ & $\mathrm{e} 0.00$ & $\mathrm{e} 0.00$ & $\mathrm{e} 0.00$ & $\mathrm{e} 0.00$ & $\mathrm{e} 0.00$ & $\mathrm{e} 0.00$ & $\mathrm{e} 0.00$ & $\mathrm{e} 0.00$ \\
\hline 10 & $\mathrm{e} 0.00$ & $\mathrm{e} 0.00$ & $\mathrm{e} 0.00$ & $\mathrm{e} 0.00$ & $\mathrm{e} 0.00$ & $\mathrm{e} 0.00$ & e0.00 & $\mathrm{e} 0.00$ & $\mathrm{e} 0.00$ & $\mathrm{e} 0.00$ & $\mathrm{e} 0.00$ & $\mathrm{e} 0.00$ \\
\hline 11 & $\mathrm{e} 0.00$ & $\mathrm{e} 0.00$ & $\mathrm{e} 0.00$ & $\mathrm{e} 0.00$ & $\mathrm{e} 0.00$ & $\mathrm{e} 0.00$ & e 4.9 & $\mathrm{e} 0.00$ & $\mathrm{e} 0.00$ & $\mathrm{e} 0.00$ & $\mathrm{e} 0.00$ & $\mathrm{e} 0.00$ \\
\hline 12 & e 0.00 & e 0.00 & $\mathrm{e} 0.00$ & e0.00 & $\mathrm{e} 0.00$ & $\mathrm{e} 0.00$ & e8. 5 & e 0.12 & $\mathrm{e} 0.00$ & e 0.00 & e 0.00 & $\mathrm{e} 0.00$ \\
\hline 13 & e 0.00 & e 0.00 & $\mathrm{e} 0.00$ & e 0.00 & $\mathrm{e} 0.00$ & $\mathrm{e} 0.00$ & e3. 4 & e 0.00 & $\mathrm{e} 0.00$ & e 0.00 & e 0.00 & $\mathrm{e} 0.00$ \\
\hline 14 & e 0.00 & $\mathrm{e} 0.00$ & $\mathrm{e} 0.00$ & $\mathrm{e} 0.00$ & $\mathrm{e} 0.00$ & 2.6 & e2. 3 & $\mathrm{e} 0.00$ & $\mathrm{e} 0.00$ & e 0.00 & $\mathrm{e} 0.00$ & $\mathrm{e} 0.00$ \\
\hline 15 & $\mathrm{e} 0.00$ & $\mathrm{e} 0.00$ & $\mathrm{e} 0.00$ & $\mathrm{e} 0.00$ & $\mathrm{e} 0.00$ & e7.7 & e1.7 & $\mathrm{e} 0.00$ & $\mathrm{e} 0.00$ & $\mathrm{e} 0.00$ & $\mathrm{e} 0.00$ & $\mathrm{e} 0.00$ \\
\hline 16 & $\mathrm{e} 0.00$ & e 0.00 & e0.00 & e 0.00 & e 0.00 & e 0.46 & e1.3 & e 0.00 & $\mathrm{e} 0.00$ & e 0.00 & e 0.00 & $\mathrm{e} 0.00$ \\
\hline 17 & $\mathrm{e} 0.00$ & $\mathrm{e} 0.00$ & $\mathrm{e} 0.00$ & e0.00 & $\mathrm{e} 0.00$ & $\mathrm{e} 0.04$ & e1.5 & $\mathrm{e} 0.00$ & $\mathrm{e} 0.00$ & $\mathrm{e} 0.00$ & $\mathrm{e} 0.00$ & $\mathrm{e} 0.00$ \\
\hline 18 & $\mathrm{e} 0.00$ & e 0.00 & e0.00 & e 0.00 & e 0.00 & e0.00 & e1.3 & e 0.00 & $\mathrm{e} 0.00$ & e 0.00 & e 0.00 & $\mathrm{e} 0.00$ \\
\hline 19 & e 0.00 & e 0.00 & e0.00 & e 0.00 & $\mathrm{e} 0.00$ & e0.00 & e1. 6 & e 0.00 & e0.00 & e 0.00 & e 0.00 & $\mathrm{e} 0.00$ \\
\hline 20 & e 0.00 & e 0.00 & $\mathrm{e} 0.00$ & $\mathrm{e} 0.00$ & e0.00 & $\mathrm{e} 0.00$ & e1. 8 & e 0.00 & e 0.00 & e 0.00 & e 0.00 & $\mathrm{e} 0.00$ \\
\hline 21 & $\mathrm{e} 0.00$ & $\mathrm{e} 0.00$ & $\mathrm{e} 0.00$ & $\mathrm{e} 0.00$ & $\mathrm{e} 0.00$ & $\mathrm{e} 0.00$ & e1.1 & $\mathrm{e} 0.00$ & $\mathrm{e} 0.00$ & $\mathrm{e} 0.00$ & $\mathrm{e} 0.00$ & $\mathrm{e} 0.00$ \\
\hline 22 & e 0.00 & $\mathrm{e} 0.00$ & e0.00 & e 0.00 & e0.00 & e0.00 & e0.26 & e 0.00 & e0.00 & e 0.00 & e 0.00 & $\mathrm{e} 0.00$ \\
\hline 23 & $\mathrm{e} 0.00$ & $\mathrm{e} 0.00$ & $\mathrm{e} 0.00$ & $\mathrm{e} 0.00$ & e0.00 & $\mathrm{e} 0.66$ & e0.04 & $\mathrm{e} 0.00$ & $\mathrm{e} 0.00$ & $\mathrm{e} 0.00$ & $\mathrm{e} 0.00$ & $\mathrm{e} 0.00$ \\
\hline 24 & $\mathrm{e} 0.00$ & $\mathrm{e} 0.00$ & $\mathrm{e} 0.00$ & $\mathrm{e} 0.00$ & $\mathrm{e} 0.00$ & e4. 6 & e0.07 & $\mathrm{e} 0.00$ & $\mathrm{e} 0.00$ & $\mathrm{e} 0.00$ & $\mathrm{e} 0.00$ & $\mathrm{e} 0.00$ \\
\hline 25 & e 0.00 & e 0.00 & e0.00 & e2. 5 & e0.00 & e2.1 & e0.00 & e 0.00 & $\mathrm{e} 0.00$ & e 0.00 & e 0.00 & $\mathrm{e} 0.00$ \\
\hline 26 & e 0.00 & e 0.00 & e0.00 & e0.79 & e 0.00 & $\mathrm{e} 2.4$ & e0.00 & e 0.00 & $\mathrm{e} 0.00$ & e 0.00 & e 0.00 & $\mathrm{e} 0.00$ \\
\hline 27 & e 0.00 & $\mathrm{e} 0.00$ & e0.00 & $\mathrm{e} 0.00$ & $\mathrm{e} 0.00$ & e3.1 & e0.00 & $\mathrm{e} 0.00$ & e0.00 & e 0.00 & e 0.00 & $\mathrm{e} 0.00$ \\
\hline 28 & e 0.00 & e 0.00 & e0.00 & e 0.00 & e0.00 & $\mathrm{e} 2.4$ & e0.00 & e 0.00 & $\mathrm{e} 0.00$ & e 0.00 & e 0.00 & $\mathrm{e} 0.00$ \\
\hline 29 & e 0.00 & e 0.00 & e0.00 & e1. 5 & e0.00 & e1. 6 & e0.00 & e 0.00 & $\mathrm{e} 0.00$ & e 0.00 & e 0.00 & $\mathrm{e} 0.00$ \\
\hline 30 & $\mathrm{e} 0.00$ & e 0.00 & e0.00 & e 0.75 & --- & $\mathrm{e} 2.0$ & e0.00 & e 0.00 & e0.00 & e 0.00 & e 0.00 & $\mathrm{e} 0.00$ \\
\hline 31 & $\mathrm{e} 0.00$ & --- & $\mathrm{e} 0.00$ & e1. 8 & --- & e5. 5 & --- & $\mathrm{e} 0.00$ & --- & $\mathrm{e} 0.00$ & $\mathrm{e} 0.00$ & --- \\
\hline TOTAL & 0.00 & 0.00 & 0.00 & 7.34 & 1.02 & 35.16 & 38.66 & 0.12 & 0.00 & 0.00 & 0.00 & 0.00 \\
\hline MAX & 0.00 & 0.00 & 0.00 & 2.5 & 0.37 & 7.7 & 8.5 & 0.12 & 0.00 & 0.00 & 0.00 & 0.00 \\
\hline MIN & 0.00 & 0.00 & 0.00 & 0.00 & 0.00 & 0.00 & 0.00 & 0.00 & 0.00 & 0.00 & 0.00 & 0.00 \\
\hline TOTAL Q & 0.00 & 5.10 & 0.00 & 271.00 & 49.60 & 953.99 & 1230.85 & 3.60 & 0.00 & 0.00 & 0.00 & 0.00 \\
\hline WTR YR & 2004 & TOTAL 82.30 & MEAN & $0.22 \quad \operatorname{MAX}$ & 8.5 MIN & 0.00 & 0.00 & & & & & \\
\hline
\end{tabular}


Table 22B. Daily-mean loads of nitrogen, nitrite plus nitrate, dissolved, during October 1, 2004, to September 30, 2005, Waiakea Stream at Hilo (16701300), Hilo, Hawaii.

\section{STATION NUMBER 16701300 Waiakea Stream at Hilo, Hawaii LATITUDE 194238 LONGITUDE 1550502 OLDHI \\ Nitrogen, nitrite + nitrate, dissolved, Ibs/day as $\mathbf{N}$ WATER YEAR OCTOBER 2004 TO SEPTEMBER 2005 DAILY MEAN VALUES}

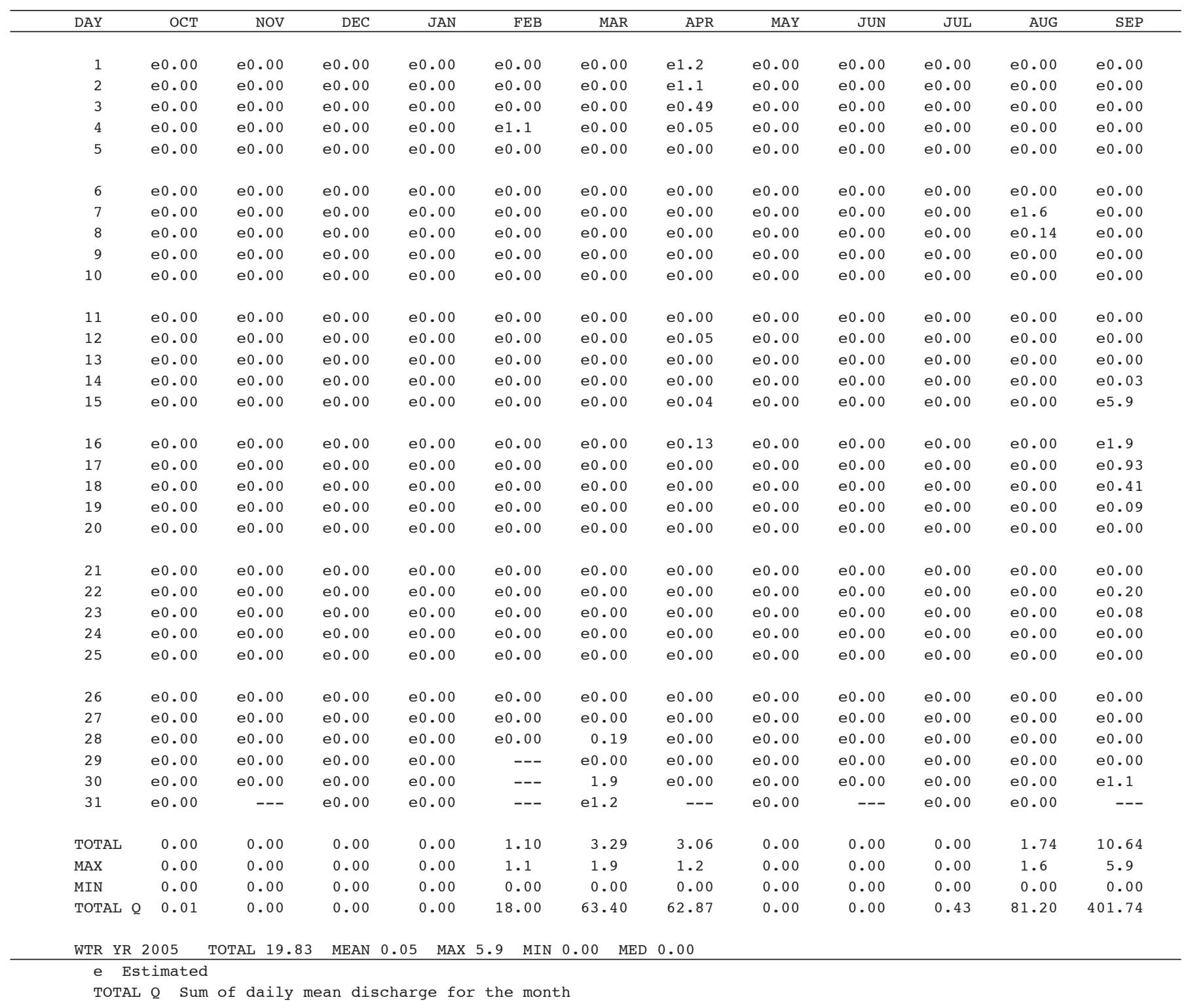


Table 23A. Daily-mean loads of total phosphorus during October 1, 2003, to September 30, 2004, Waiakea Stream at Hilo (16701300), Hilo, Hawaii.

\section{STATION NUMBER 16701300 Waiakea Stream at Hilo, Hawaii LATITUDE 194238 LONGITUDE 1550502 OLDHI \\ Phosphorus, water, unfiltered, pounds per day WATER YEAR OCTOBER 2003 TO SEPTEMBER 2004 DAILY MEAN VALUES}

\begin{tabular}{|c|c|c|c|c|c|c|c|c|c|c|c|c|}
\hline DAY & $\mathrm{OCT}$ & NOV & DEC & JAN & FEB & MAR & APR & MAY & JUN & JUL & AUG & SEP \\
\hline 1 & e 0.00 & e 0.00 & e0.00 & e 0.00 & e2. 41 & e0 0.00 & e6.85 & e 0.00 & $\mathrm{e} 0.00$ & e 0.00 & e0.00 & $\mathrm{e} 0.00$ \\
\hline 2 & $\mathrm{e} 0.00$ & e 0.00 & $e 0.00$ & $\mathrm{e} 0.00$ & e2.15 & $\mathrm{e} 0.00$ & e4.15 & $\mathrm{e} 0.00$ & $\mathrm{e} 0.00$ & $\mathrm{e} 0.00$ & $\mathrm{e} 0.00$ & $\mathrm{e} 0.00$ \\
\hline 3 & $\mathrm{e} 0.00$ & e0.00 & e0.00 & $\mathrm{e} 0.00$ & $\mathrm{e} 0.28$ & $\mathrm{e} 0.00$ & e1.96 & $\mathrm{e} 0.00$ & $\mathrm{e} 0.00$ & $\mathrm{e} 0.00$ & $\mathrm{e} 0.00$ & $\mathrm{e} 0.00$ \\
\hline 4 & $\mathrm{e} 0.00$ & e 0.00 & e0.00 & e 0.00 & e0 0.00 & e0.00 & e0.45 & e 0.00 & e0.00 & e 0.00 & e 0.00 & $\mathrm{e} 0.00$ \\
\hline 5 & e 0.00 & $\mathrm{e} 0.00$ & e0.00 & e 0.00 & $\mathrm{e} 0.00$ & e 0.00 & e0.01 & e 0.00 & e 0.00 & e 0.00 & $e 0.00$ & $\mathrm{e} 0.00$ \\
\hline 6 & $\mathrm{e} 0.00$ & e 0.00 & e0.00 & e 0.00 & e1.31 & e0.00 & e0 0.00 & e 0.00 & e0.00 & e 0.00 & e 0.00 & $\mathrm{e} 0.00$ \\
\hline 7 & $\mathrm{e} 0.00$ & e 0.00 & e0.00 & e 0.00 & e 0.24 & e0.00 & e0 0.00 & e 0.00 & e0.00 & e 0.00 & e 0.00 & $\mathrm{e} 0.00$ \\
\hline 8 & $\mathrm{e} 0.00$ & $\mathrm{e} 0.00$ & e0.00 & $\mathrm{e} 0.00$ & $\mathrm{e} 0.36$ & $\mathrm{e} 0.00$ & e0.00 & $\mathrm{e} 0.00$ & $\mathrm{e} 0.00$ & $\mathrm{e} 0.00$ & $\mathrm{e} 0.00$ & $\mathrm{e} 0.00$ \\
\hline 9 & $\mathrm{e} 0.00$ & $\mathrm{e} 0.00$ & e0.00 & $\mathrm{e} 0.00$ & $\mathrm{e} 0.00$ & $\mathrm{e} 0.00$ & e0.00 & $\mathrm{e} 0.00$ & $\mathrm{e} 0.00$ & $\mathrm{e} 0.00$ & $\mathrm{e} 0.00$ & $\mathrm{e} 0.00$ \\
\hline 10 & $\mathrm{e} 0.00$ & $\mathrm{e} 0.00$ & e0.00 & $\mathrm{e} 0.00$ & $\mathrm{e} 0.00$ & $\mathrm{e} 0.00$ & $\mathrm{e} 0.43$ & $\mathrm{e} 0.00$ & $\mathrm{e} 0.00$ & $\mathrm{e} 0.00$ & $\mathrm{e} 0.00$ & $\mathrm{e} 0.00$ \\
\hline 11 & $\mathrm{e} 0.00$ & $\mathrm{e} 0.00$ & $e 0.00$ & $\mathrm{e} 0.00$ & $\mathrm{e} 0.00$ & $\mathrm{e} 0.00$ & e 46.1 & $\mathrm{e} 0.00$ & $\mathrm{e} 0.00$ & $\mathrm{e} 0.00$ & $\mathrm{e} 0.00$ & $\mathrm{e} 0.00$ \\
\hline 12 & e 0.00 & e 0.00 & $e 0.00$ & e0.00 & $\mathrm{e} 0.00$ & $\mathrm{e} 0.00$ & e176 & $e 0.60$ & $\mathrm{e} 0.00$ & e 0.00 & $\mathrm{e} 0.00$ & $\mathrm{e} 0.00$ \\
\hline 13 & e 0.00 & e 0.00 & $e 0.00$ & e 0.00 & $\mathrm{e} 0.00$ & $\mathrm{e} 0.00$ & e 56.2 & e 0.00 & $\mathrm{e} 0.00$ & e 0.00 & $\mathrm{e} 0.00$ & $\mathrm{e} 0.00$ \\
\hline 14 & e 0.00 & e 0.00 & e0.00 & e0.00 & e 0.00 & e 43.2 & e 30.3 & e 0.00 & e0.00 & e 0.00 & e 0.00 & $\mathrm{e} 0.00$ \\
\hline 15 & $\mathrm{e} 0.00$ & $\mathrm{e} 0.00$ & e0.00 & $\mathrm{e} 0.00$ & $\mathrm{e} 0.00$ & 105 & e16. 6 & $\mathrm{e} 0.00$ & $\mathrm{e} 0.00$ & $\mathrm{e} 0.00$ & $\mathrm{e} 0.00$ & $\mathrm{e} 0.00$ \\
\hline 16 & $\mathrm{e} 0.00$ & e 0.00 & e0.00 & e 0.00 & e 0.00 & e1.01 & e8. 25 & e 0.00 & $\mathrm{e} 0.00$ & e 0.00 & $\mathrm{e} 0.00$ & $\mathrm{e} 0.00$ \\
\hline 17 & $\mathrm{e} 0.00$ & $\mathrm{e} 0.00$ & $e 0.00$ & e0.00 & $\mathrm{e} 0.00$ & $\mathrm{e} 0.02$ & e9.47 & $\mathrm{e} 0.00$ & $\mathrm{e} 0.00$ & $\mathrm{e} 0.00$ & $\mathrm{e} 0.00$ & $\mathrm{e} 0.00$ \\
\hline 18 & $\mathrm{e} 0.00$ & $\mathrm{e} 0.00$ & $e 0.00$ & e0.00 & $\mathrm{e} 0.00$ & $\mathrm{e} 0.00$ & e5.36 & $\mathrm{e} 0.00$ & $\mathrm{e} 0.00$ & $\mathrm{e} 0.00$ & $\mathrm{e} 0.00$ & $\mathrm{e} 0.00$ \\
\hline 19 & e 0.00 & e 0.00 & $e 0.00$ & e0.00 & e0 0.00 & e0.00 & e2.34 & e 0.00 & e0.00 & e 0.00 & e 0.00 & $\mathrm{e} 0.00$ \\
\hline 20 & $\mathrm{e} 0.00$ & $\mathrm{e} 0.00$ & $e 0.00$ & $\mathrm{e} 0.00$ & $\mathrm{e} 0.00$ & $\mathrm{e} 0.00$ & e1.53 & e 0.00 & e 0.00 & e 0.00 & $e 0.00$ & $\mathrm{e} 0.00$ \\
\hline 21 & $\mathrm{e} 0.00$ & $\mathrm{e} 0.00$ & $e 0.00$ & $\mathrm{e} 0.00$ & $\mathrm{e} 0.00$ & $\mathrm{e} 0.00$ & $\mathrm{e} 0.60$ & $\mathrm{e} 0.00$ & $\mathrm{e} 0.00$ & $\mathrm{e} 0.00$ & $\mathrm{e} 0.00$ & $\mathrm{e} 0.00$ \\
\hline 22 & e 0.00 & $\mathrm{e} 0.00$ & $e 0.00$ & e 0.00 & e0.00 & e0.00 & e0.10 & e 0.00 & e0.00 & e 0.00 & $\mathrm{e} 0.00$ & $\mathrm{e} 0.00$ \\
\hline 23 & $\mathrm{e} 0.00$ & $\mathrm{e} 0.00$ & $e 0.00$ & $\mathrm{e} 0.00$ & e0.00 & e11.2 & e0.01 & $\mathrm{e} 0.00$ & $\mathrm{e} 0.00$ & $\mathrm{e} 0.00$ & $\mathrm{e} 0.00$ & $\mathrm{e} 0.00$ \\
\hline 24 & $\mathrm{e} 0.00$ & $\mathrm{e} 0.00$ & $e 0.00$ & e0.00 & $\mathrm{e} 0.00$ & e48.6 & e0.01 & $\mathrm{e} 0.00$ & $\mathrm{e} 0.00$ & $\mathrm{e} 0.00$ & $\mathrm{e} 0.00$ & $\mathrm{e} 0.00$ \\
\hline 25 & e 0.00 & e 0.00 & $e 0.00$ & e46.6 & e 0.00 & e17.8 & e0.00 & e 0.00 & $\mathrm{e} 0.00$ & e 0.00 & e0.00 & $\mathrm{e} 0.00$ \\
\hline 26 & e 0.00 & e 0.00 & $e 0.00$ & e12. 5 & e 0.00 & e8. 43 & e0.00 & e 0.00 & $\mathrm{e} 0.00$ & e 0.00 & e0.00 & $\mathrm{e} 0.00$ \\
\hline 27 & e 0.00 & $\mathrm{e} 0.00$ & $e 0.00$ & $\mathrm{e} 0.00$ & e0.00 & e11.4 & $\mathrm{e} 0.00$ & $\mathrm{e} 0.00$ & e0.00 & e 0.00 & e0.00 & $\mathrm{e} 0.00$ \\
\hline 28 & e 0.00 & e 0.00 & $e 0.00$ & e 0.00 & e0.00 & e 4.43 & e0.00 & e 0.00 & $\mathrm{e} 0.00$ & e 0.00 & e0.00 & $\mathrm{e} 0.00$ \\
\hline 29 & e 0.00 & e 0.00 & $e 0.00$ & e10.6 & e0.00 & e3.29 & e0.00 & e 0.00 & $\mathrm{e} 0.00$ & e 0.00 & e0.00 & $\mathrm{e} 0.00$ \\
\hline 30 & $\mathrm{e} 0.00$ & e 0.52 & e0.00 & e3. 65 & --- & e5.04 & e0.00 & e 0.00 & e0.00 & e 0.00 & e0.00 & $\mathrm{e} 0.00$ \\
\hline 31 & $\mathrm{e} 0.00$ & --- & $e 0.00$ & e14. 2 & --- & e32. 6 & --- & $\mathrm{e} 0.00$ & --- & $\mathrm{e} 0.00$ & $\mathrm{e} 0.00$ & --- \\
\hline TOTAL & 0.00 & 0.52 & 0.00 & 87.55 & 6.75 & 292.02 & 366.72 & 0.60 & 0.00 & 0.00 & 0.00 & 0.00 \\
\hline MAX & 0.00 & 0.52 & 0.00 & 46.6 & 2.41 & 105 & 176 & 0.60 & 0.00 & 0.00 & 0.00 & 0.00 \\
\hline MIN & 0.00 & 0.00 & 0.00 & 0.00 & 0.00 & 0.00 & 0.00 & 0.00 & 0.00 & 0.00 & 0.00 & 0.00 \\
\hline TOTAL Q & 0.00 & 5.10 & 0.00 & 271.00 & 49.60 & 953.99 & 1230.85 & 3.60 & 0.00 & 0.00 & 0.00 & 0.00 \\
\hline WTR YR & 2004 & TOTAL 754.16 & MEAN & 2.06 MAX & 176 MIN & $0.00 \quad \mathrm{~N}$ & MED 0.00 & & & & & \\
\hline
\end{tabular}


Table 23B. Daily-mean loads of total phosphorus during October 1, 2004, to September 30, 2005, Waiakea Stream at Hilo (16701300), Hilo, Hawaii.

\section{STATION NUMBER 16701300 Waiakea Stream at Hilo, Hawaii LATITUDE 194238 LONGITUDE 1550502 OLDHI \\ Phosphorus, water, unfiltered, pounds per day WATER YEAR OCTOBER 2004 TO SEPTEMBER 2005 DAILY MEAN VALUES}

\begin{tabular}{|c|c|c|c|c|c|c|c|c|c|c|c|c|}
\hline DAY & OCT & NOV & DEC & JAN & FEB & MAR & APR & MAY & JUN & JUL & AUG & SEP \\
\hline 1 & $\mathrm{e} 0.00$ & $\mathrm{e} 0.00$ & $\mathrm{e} 0.00$ & $\mathrm{e} 0.00$ & $\mathrm{e} 0.00$ & $\mathrm{e} 0.00$ & e3.23 & $\mathrm{e} 0.00$ & $\mathrm{e} 0.00$ & $\mathrm{e} 0.00$ & $\mathrm{e} 0.00$ & $\mathrm{e} 0.00$ \\
\hline 2 & $\mathrm{e} 0.00$ & $\mathrm{e} 0.00$ & $\mathrm{e} 0.00$ & $\mathrm{e} 0.00$ & $\mathrm{e} 0.00$ & $\mathrm{e} 0.00$ & e2.36 & e0.00 & e 0.00 & $\mathrm{e} 0.00$ & e0.00 & $\mathrm{e} 0.00$ \\
\hline 3 & $\mathrm{e} 0.00$ & $\mathrm{e} 0.00$ & $\mathrm{e} 0.00$ & $\mathrm{e} 0.00$ & $\mathrm{e} 0.00$ & $\mathrm{e} 0.00$ & $\mathrm{e} 0.41$ & $\mathrm{e} 0.00$ & $\mathrm{e} 0.00$ & $\mathrm{e} 0.00$ & $\mathrm{e} 0.00$ & $\mathrm{e} 0.00$ \\
\hline 4 & e 0.00 & e 0.00 & e 0.00 & e0.00 & 1.41 & e 0.00 & $\mathrm{e} 0.01$ & e0.00 & e0.00 & e 0.00 & e0.00 & $\mathrm{e} 0.00$ \\
\hline 5 & e 0.00 & e 0.00 & e 0.00 & e0.00 & e0.00 & e 0.00 & e0.00 & e0.00 & e0.00 & e 0.00 & e0.00 & $\mathrm{e} 0.00$ \\
\hline 6 & $\mathrm{e} 0.00$ & $\mathrm{e} 0.00$ & $\mathrm{e} 0.00$ & $\mathrm{e} 0.00$ & $\mathrm{e} 0.00$ & $\mathrm{e} 0.00$ & $\mathrm{e} 0.00$ & $\mathrm{e} 0.00$ & $\mathrm{e} 0.00$ & $\mathrm{e} 0.00$ & $\mathrm{e} 0.00$ & $\mathrm{e} 0.00$ \\
\hline 7 & $\mathrm{e} 0.00$ & $\mathrm{e} 0.00$ & $\mathrm{e} 0.00$ & $\mathrm{e} 0.00$ & $\mathrm{e} 0.00$ & $\mathrm{e} 0.00$ & $\mathrm{e} 0.00$ & $\mathrm{e} 0.00$ & $\mathrm{e} 0.00$ & $\mathrm{e} 0.00$ & e29.9 & $\mathrm{e} 0.00$ \\
\hline 8 & e 0.00 & e 0.00 & e 0.00 & e0.00 & e0.00 & e 0.00 & $\mathrm{e} 0.00$ & e 0.00 & e 0.00 & e 0.00 & e0. 48 & $\mathrm{e} 0.00$ \\
\hline 9 & $\mathrm{e} 0.00$ & $\mathrm{e} 0.00$ & $\mathrm{e} 0.00$ & $\mathrm{e} 0.00$ & $\mathrm{e} 0.00$ & $\mathrm{e} 0.00$ & $\mathrm{e} 0.00$ & $\mathrm{e} 0.00$ & $\mathrm{e} 0.00$ & $\mathrm{e} 0.00$ & $\mathrm{e} 0.00$ & $\mathrm{e} 0.00$ \\
\hline 10 & e0.00 & e 0.00 & e0.00 & $\mathrm{e} 0.00$ & e0.00 & e 0.00 & $\mathrm{e} 0.00$ & e 0.00 & e 0.00 & e 0.00 & e0.00 & $\mathrm{e} 0.00$ \\
\hline 11 & $\mathrm{e} 0.00$ & $\mathrm{e} 0.00$ & $\mathrm{e} 0.00$ & $\mathrm{e} 0.00$ & $\mathrm{e} 0.00$ & $\mathrm{e} 0.00$ & $\mathrm{e} 0.00$ & $\mathrm{e} 0.00$ & $\mathrm{e} 0.00$ & $\mathrm{e} 0.00$ & $\mathrm{e} 0.00$ & $\mathrm{e} 0.00$ \\
\hline 12 & $\mathrm{e} 0.00$ & $\mathrm{e} 0.00$ & $\mathrm{e} 0.00$ & $\mathrm{e} 0.00$ & $\mathrm{e} 0.00$ & $\mathrm{e} 0.00$ & $\mathrm{e} 0.07$ & $\mathrm{e} 0.00$ & $\mathrm{e} 0.00$ & $\mathrm{e} 0.00$ & $\mathrm{e} 0.00$ & $\mathrm{e} 0.00$ \\
\hline 13 & $\mathrm{e} 0.00$ & $\mathrm{e} 0.00$ & $\mathrm{e} 0.00$ & $\mathrm{e} 0.00$ & $\mathrm{e} 0.00$ & $\mathrm{e} 0.00$ & $\mathrm{e} 0.00$ & $\mathrm{e} 0.00$ & $\mathrm{e} 0.00$ & $\mathrm{e} 0.00$ & $\mathrm{e} 0.00$ & $\mathrm{e} 0.00$ \\
\hline 14 & e 0.00 & e 0.00 & $\mathrm{e} 0.00$ & e 0.00 & e 0.00 & e 0.00 & e0.00 & e 0.00 & e 0.00 & e 0.00 & e0.00 & $\mathrm{e} 0.02$ \\
\hline 15 & e0.00 & e 0.00 & e0.00 & $\mathrm{e} 0.00$ & $\mathrm{e} 0.00$ & e 0.00 & $\mathrm{e} 0.07$ & e0.00 & e0.00 & e 0.00 & e0.00 & e79.1 \\
\hline 16 & $\mathrm{e} 0.00$ & $\mathrm{e} 0.00$ & $\mathrm{e} 0.00$ & $\mathrm{e} 0.00$ & $\mathrm{e} 0.00$ & $\mathrm{e} 0.00$ & $\mathrm{e} 0.26$ & $\mathrm{e} 0.00$ & $\mathrm{e} 0.00$ & $\mathrm{e} 0.00$ & $\mathrm{e} 0.00$ & e9.17 \\
\hline 17 & e0.00 & e 0.00 & $\mathrm{e} 0.00$ & $\mathrm{e} 0.00$ & e0.00 & e 0.00 & $\mathrm{e} 0.00$ & e0.00 & e0.00 & e 0.00 & e0.00 & e1.21 \\
\hline 18 & e0.00 & e 0.00 & $\mathrm{e} 0.00$ & $\mathrm{e} 0.00$ & e0.00 & e 0.00 & $\mathrm{e} 0.00$ & e0.00 & e0.00 & e 0.00 & $\mathrm{e} 0.00$ & e0.53 \\
\hline 19 & $\mathrm{e} 0.00$ & $\mathrm{e} 0.00$ & $\mathrm{e} 0.00$ & $\mathrm{e} 0.00$ & $\mathrm{e} 0.00$ & $\mathrm{e} 0.00$ & $\mathrm{e} 0.00$ & $\mathrm{e} 0.00$ & e 0.00 & $\mathrm{e} 0.00$ & $\mathrm{e} 0.00$ & $\mathrm{e} 0.11$ \\
\hline 20 & $\mathrm{e} 0.00$ & $\mathrm{e} 0.00$ & e0.00 & e0.00 & e0.00 & e0.00 & e0.00 & e0.00 & e0.00 & e0.00 & e0.00 & $\mathrm{e} 0.00$ \\
\hline 21 & $\mathrm{e} 0.00$ & $\mathrm{e} 0.00$ & $\mathrm{e} 0.00$ & $\mathrm{e} 0.00$ & $\mathrm{e} 0.00$ & $\mathrm{e} 0.00$ & $\mathrm{e} 0.00$ & $\mathrm{e} 0.00$ & e0.00 & $\mathrm{e} 0.00$ & $\mathrm{e} 0.00$ & $\mathrm{e} 0.00$ \\
\hline 22 & $\mathrm{e} 0.00$ & $\mathrm{e} 0.00$ & $\mathrm{e} 0.00$ & $\mathrm{e} 0.00$ & $\mathrm{e} 0.00$ & $\mathrm{e} 0.00$ & $\mathrm{e} 0.00$ & $\mathrm{e} 0.00$ & $\mathrm{e} 0.00$ & $\mathrm{e} 0.00$ & $\mathrm{e} 0.00$ & $\mathrm{e} 0.66$ \\
\hline 23 & e0.00 & e 0.00 & e0.00 & e0.00 & e0.00 & e 0.00 & $\mathrm{e} 0.00$ & e0.00 & e 0.00 & e 0.00 & e0.00 & e0.15 \\
\hline 24 & e0.00 & e 0.00 & e0.00 & e0.00 & e0.00 & e 0.00 & $\mathrm{e} 0.00$ & e0.00 & e 0.00 & e 0.00 & e0.00 & $\mathrm{e} 0.00$ \\
\hline 25 & $\mathrm{e} 0.00$ & $\mathrm{e} 0.00$ & $\mathrm{e} 0.00$ & $\mathrm{e} 0.00$ & $\mathrm{e} 0.00$ & $\mathrm{e} 0.00$ & $\mathrm{e} 0.00$ & $\mathrm{e} 0.00$ & $\mathrm{e} 0.00$ & $\mathrm{e} 0.00$ & $\mathrm{e} 0.00$ & $\mathrm{e} 0.00$ \\
\hline 26 & $\mathrm{e} 0.00$ & e0.00 & $\mathrm{e} 0.00$ & $\mathrm{e} 0.00$ & $\mathrm{e} 0.00$ & $\mathrm{e} 0.00$ & $\mathrm{e} 0.00$ & $\mathrm{e} 0.00$ & $\mathrm{e} 0.00$ & $\mathrm{e} 0.00$ & $\mathrm{e} 0.00$ & $\mathrm{e} 0.00$ \\
\hline 27 & e 0.00 & $\mathrm{e} 0.00$ & $\mathrm{e} 0.00$ & $\mathrm{e} 0.00$ & $\mathrm{e} 0.00$ & e 0.00 & $\mathrm{e} 0.00$ & $\mathrm{e} 0.00$ & e 0.00 & e 0.00 & $\mathrm{e} 0.00$ & $\mathrm{e} 0.00$ \\
\hline 28 & $\mathrm{e} 0.00$ & $\mathrm{e} 0.00$ & $\mathrm{e} 0.00$ & e0.00 & $\mathrm{e} 0.00$ & 1.98 & $\mathrm{e} 0.00$ & $\mathrm{e} 0.00$ & $\mathrm{e} 0.00$ & $\mathrm{e} 0.00$ & $\mathrm{e} 0.00$ & $\mathrm{e} 0.00$ \\
\hline 29 & $\mathrm{e} 0.00$ & $\mathrm{e} 0.00$ & $\mathrm{e} 0.00$ & e0.00 & --- & $\mathrm{e} 0.00$ & $\mathrm{e} 0.00$ & $\mathrm{e} 0.00$ & $\mathrm{e} 0.00$ & $\mathrm{e} 0.00$ & $\mathrm{e} 0.00$ & $\mathrm{e} 0.00$ \\
\hline 30 & e0.00 & e0.00 & $e 0.00$ & e0.00 & --- & 7.32 & $\mathrm{e} 0.00$ & e0.00 & e0.00 & e 0.00 & $\mathrm{e} 0.00$ & e10.3 \\
\hline 31 & e 0.00 & --- & $e 0.00$ & e0.00 & --- & e3. 85 & --- & e0.00 & --- & e 0.00 & e0.00 & --- \\
\hline TOTAL & 0.00 & 0.00 & 0.00 & 0.00 & 1.41 & 13.15 & 6.41 & 0.00 & 0.00 & 0.00 & 30.38 & 101.25 \\
\hline MAX & 0.00 & 0.00 & 0.00 & 0.00 & 1.41 & 7.32 & 3.23 & 0.00 & 0.00 & 0.00 & 29.9 & 79.1 \\
\hline MIN & 0.00 & 0.00 & 0.00 & 0.00 & 0.00 & 0.00 & 0.00 & 0.00 & 0.00 & 0.00 & 0.00 & 0.00 \\
\hline TOTAL Q & 0.01 & 0.00 & 0.00 & 0.00 & 18.00 & 63.40 & 62.87 & 0.00 & 0.00 & 0.43 & 81.20 & 401.74 \\
\hline WTR YR & 2005 & TOTAL 152.60 & MEAN & 0.42 MAX & 79.1 MIN & 0.00 & MED 0.00 & & & & & \\
\hline
\end{tabular}


Table 24A. Daily-mean discharge during October 1, 2003, to September 30, 2004, Waiakea Stream at Hilo (16701300), Hilo, Hawaii.

\section{STATION NUMBER 16701300 Waiakea Stream at Hilo, Hawaii LATITUDE 194238 LONGITUDE 1550502 OLDHI \\ Discharge, cubic feet per second \\ WATER YEAR OCTOBER 2003 TO SEPTEMBER 2004 \\ DAILY MEAN VALUES}

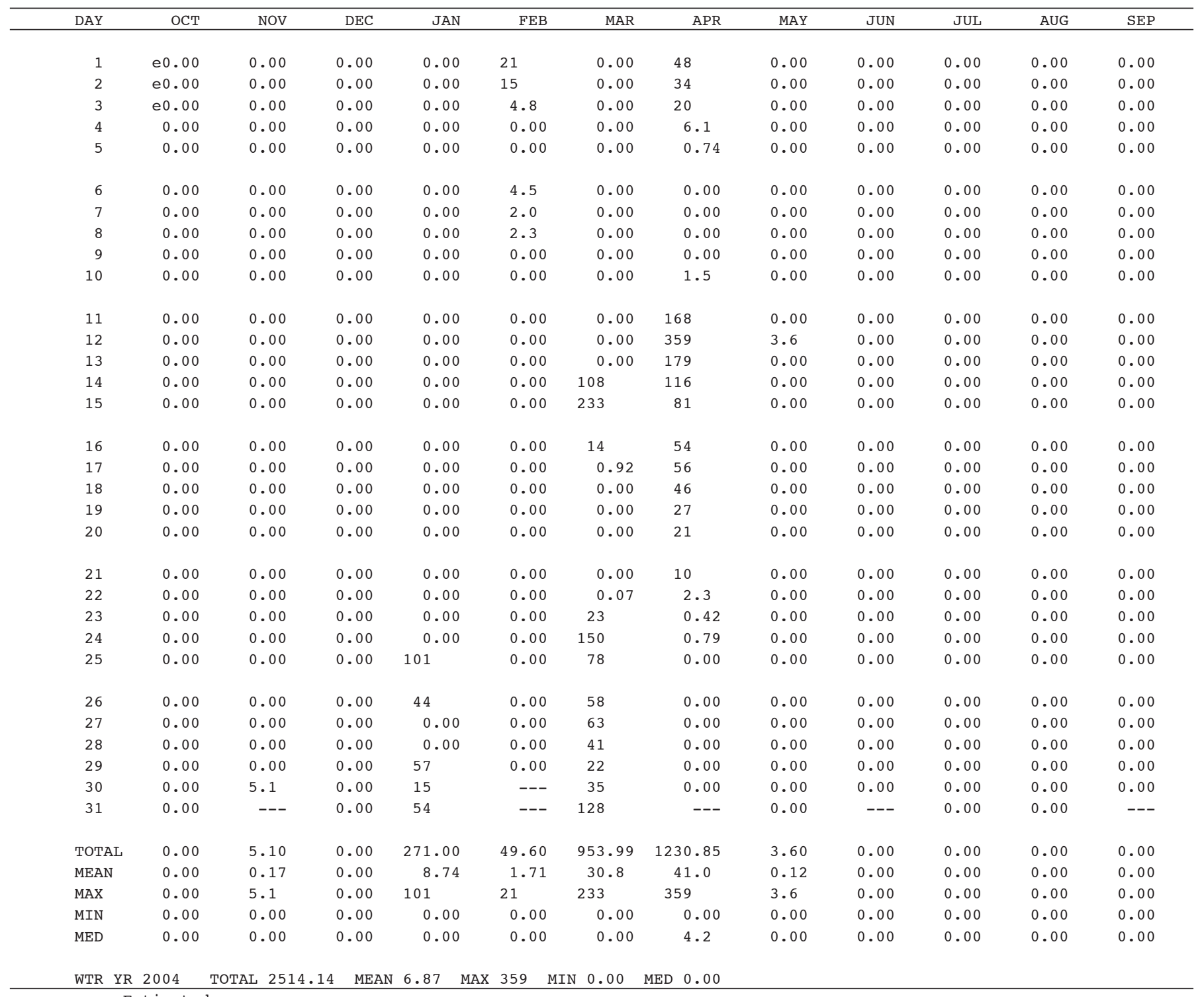


Table 24B. Daily-mean discharge during October 1, 2004, to September 30, 2005, Waiakea Stream at Hilo (16701300), Hilo, Hawaii.

\section{STATION NUMBER 16701300 Waiakea Stream at Hilo, Hawaii LATITUDE 194238 LONGITUDE 1550502 OLDHI \\ Discharge, cubic feet per second WATER YEAR OCTOBER 2004 TO SEPTEMBER 2005 \\ DAILY MEAN VALUES}

\begin{tabular}{|c|c|c|c|c|c|c|c|c|c|c|c|c|}
\hline DAY & OCT & NOV & $\mathrm{DEC}$ & JAN & FEB & MAR & APR & MAY & JUN & JUL & AUG & SEP \\
\hline 1 & 0.00 & 0.00 & 0.00 & 0.00 & $\mathrm{e} 0.00$ & 0.00 & 24 & 0.00 & $\mathrm{e} 0.00$ & 0.00 & 0.00 & 0.00 \\
\hline 2 & 0.00 & 0.00 & 0.00 & 0.00 & $\mathrm{e} 0.00$ & 0.00 & 22 & 0.00 & $\mathrm{e} 0.00$ & 0.00 & 0.00 & 0.00 \\
\hline 3 & 0.00 & 0.00 & 0.00 & 0.00 & $e 0.00$ & 0.00 & 11 & 0.00 & e0.00 & 0.00 & 0.00 & 0.00 \\
\hline 4 & 0.00 & 0.00 & 0.00 & 0.00 & e18 & 0.00 & 0.97 & 0.00 & 0.00 & 0.00 & 0.00 & 0.00 \\
\hline 5 & 0.00 & 0.00 & 0.00 & 0.00 & 0.00 & 0.00 & 0.00 & 0.00 & 0.00 & 0.00 & 0.00 & 0.00 \\
\hline 6 & 0.00 & 0.00 & 0.00 & 0.00 & 0.00 & 0.00 & 0.00 & 0.00 & 0.00 & 0.00 & 0.00 & 0.00 \\
\hline 7 & 0.00 & 0.00 & 0.00 & $\mathrm{e} 0.00$ & 0.00 & 0.00 & 0.00 & 0.00 & 0.00 & 0.00 & 77 & 0.00 \\
\hline 8 & 0.00 & 0.00 & 0.00 & $\mathrm{e} 0.00$ & 0.00 & 0.00 & 0.00 & 0.00 & 0.00 & 0.00 & 4.2 & 0.00 \\
\hline 9 & 0.00 & 0.00 & 0.00 & e0.00 & 0.00 & 0.00 & 0.00 & 0.00 & 0.00 & 0.00 & 0.00 & 0.00 \\
\hline 10 & 0.00 & 0.00 & 0.00 & $\mathrm{e} 0.00$ & 0.00 & 0.00 & 0.00 & 0.00 & 0.00 & 0.00 & 0.00 & 0.00 \\
\hline 11 & 0.00 & 0.00 & 0.00 & $\mathrm{e} 0.00$ & 0.00 & 0.00 & 0.00 & 0.00 & 0.00 & 0.00 & 0.00 & 0.00 \\
\hline 12 & 0.01 & 0.00 & 0.00 & e0.00 & 0.00 & 0.00 & 1.2 & 0.00 & 0.00 & 0.00 & 0.00 & 0.00 \\
\hline 13 & 0.00 & 0.00 & 0.00 & e0.00 & 0.00 & 0.00 & 0.00 & 0.00 & 0.00 & 0.00 & 0.00 & 0.02 \\
\hline 14 & 0.00 & 0.00 & 0.00 & $\mathrm{e} 0.00$ & 0.00 & 0.00 & 0.00 & 0.00 & 0.00 & 0.17 & 0.00 & 1.0 \\
\hline 15 & 0.00 & 0.00 & 0.00 & $\mathrm{e} 0.00$ & 0.00 & 0.00 & 1.0 & 0.00 & 0.00 & 0.26 & 0.00 & 244 \\
\hline 16 & 0.00 & 0.00 & 0.00 & $\mathrm{e} 0.00$ & 0.00 & 0.00 & 2.7 & 0.00 & 0.00 & 0.00 & 0.00 & 55 \\
\hline 17 & 0.00 & 0.00 & 0.00 & $\mathrm{e} 0.00$ & 0.00 & $\mathrm{e} 0.00$ & 0.00 & 0.00 & 0.00 & 0.00 & 0.00 & 23 \\
\hline 18 & 0.00 & 0.00 & 0.00 & $\mathrm{e} 0.00$ & 0.00 & 0.00 & 0.00 & 0.00 & 0.00 & 0.00 & 0.00 & 15 \\
\hline 19 & 0.00 & 0.00 & 0.00 & e0.00 & 0.00 & 0.00 & 0.00 & 0.00 & 0.00 & 0.00 & 0.00 & 5.9 \\
\hline 20 & 0.00 & 0.00 & 0.00 & e0.00 & 0.00 & 0.00 & 0.00 & 0.00 & 0.00 & 0.00 & 0.00 & 0.42 \\
\hline 21 & 0.00 & 0.00 & 0.00 & $\mathrm{e} 0.00$ & 0.00 & 0.00 & 0.00 & 0.00 & 0.00 & 0.00 & 0.00 & 0.00 \\
\hline 22 & 0.00 & 0.00 & 0.00 & $\mathrm{e} 0.00$ & 0.00 & 0.00 & 0.00 & 0.00 & 0.00 & 0.00 & 0.00 & 6.3 \\
\hline 23 & 0.00 & 0.00 & 0.00 & $\mathrm{e} 0.00$ & 0.00 & 0.00 & 0.00 & 0.00 & 0.00 & 0.00 & 0.00 & 2.1 \\
\hline 24 & 0.00 & 0.00 & 0.00 & $\mathrm{e} 0.00$ & 0.00 & 0.00 & 0.00 & 0.00 & 0.00 & 0.00 & 0.00 & 0.00 \\
\hline 25 & 0.00 & 0.00 & 0.00 & $\mathrm{e} 0.00$ & 0.00 & 0.00 & 0.00 & 0.00 & 0.00 & 0.00 & 0.00 & 0.00 \\
\hline 26 & 0.00 & 0.00 & 0.00 & $\mathrm{e} 0.00$ & 0.00 & 0.00 & 0.00 & 0.00 & 0.00 & 0.00 & 0.00 & 0.00 \\
\hline 27 & 0.00 & 0.00 & 0.00 & $\mathrm{e} 0.00$ & 0.00 & 0.00 & 0.00 & $\mathrm{e} 0.00$ & 0.00 & 0.00 & 0.00 & 0.00 \\
\hline 28 & 0.00 & 0.00 & 0.00 & $\mathrm{e} 0.00$ & 0.00 & 5.4 & 0.00 & $\mathrm{e} 0.00$ & 0.00 & 0.00 & 0.00 & 0.00 \\
\hline 29 & 0.00 & 0.00 & 0.00 & e0.00 & --- & 0.00 & 0.00 & e0.00 & 0.00 & 0.00 & 0.00 & 0.00 \\
\hline 30 & 0.00 & 0.00 & 0.00 & $\mathrm{e} 0.00$ & --- & 36 & 0.00 & $\mathrm{e} 0.00$ & 0.00 & 0.00 & 0.00 & 49 \\
\hline 31 & 0.00 & --- & 0.00 & e0.00 & --- & 22 & --- & e0.00 & --- & 0.00 & 0.00 & --- \\
\hline TOTAL & 0.01 & 0.00 & 0.00 & 0.00 & 18.00 & 63.40 & 62.87 & 0.00 & 0.00 & 0.43 & 81.20 & 401.74 \\
\hline MEAN & 0.00 & 0.00 & 0.00 & 0.00 & 0.64 & 2.05 & 2.10 & 0.00 & 0.00 & 0.01 & 2.62 & 13.4 \\
\hline MAX & 0.01 & 0.00 & 0.00 & 0.00 & 18 & 36 & 24 & 0.00 & 0.00 & 0.26 & 77 & 244 \\
\hline MIN & 0.00 & 0.00 & 0.00 & 0.00 & 0.00 & 0.00 & 0.00 & 0.00 & 0.00 & 0.00 & 0.00 & 0.00 \\
\hline MED & 0.00 & 0.00 & 0.00 & 0.00 & 0.00 & 0.00 & 0.00 & 0.00 & 0.00 & 0.00 & 0.00 & 0.00 \\
\hline WTR YR & 2005 & TOTAL 627.65 & MEAN & 1.72 MAX & 244 MIN & 0.00 MED & 0.00 & & & & & \\
\hline
\end{tabular}


72 Suspended-Sediment and Nutrient Loads for Waiakea and Alenaio Streams, Hilo, Hawaii, 2003-2006

Table 24C. Daily-mean discharge during October 1, 2005, to September 30, 2006, Waiakea Stream at Hilo (16701300), Hilo, Hawaii.

STATION NUMBER 16701300 Waiakea Stream at Hilo, Hawaii

LATITUDE 194238 LONGITUDE 1550502 OLDHI

Discharge, cubic feet per second

WATER YEAR OCTOBER 2005 TO SEPTEMBER 2006

DAILY MEAN VALUES

\begin{tabular}{|c|c|c|c|c|c|c|c|c|c|c|c|c|}
\hline DAY & OCT & NOV & DEC & JAN & FEB & MAR & APR & MAY & JUN & JUL & AUG & SEP \\
\hline 1 & 6.1 & --- & --- & --- & --- & --- & --- & --- & --- & --- & --- & --- \\
\hline 2 & 0.52 & --- & --- & --- & --- & --- & --- & --- & --- & --- & --- & --- \\
\hline 3 & 0.23 & --- & --- & --- & --- & --- & --- & --- & --- & --- & --- & --- \\
\hline 4 & 0.38 & --- & --- & --- & --- & --- & --- & --- & --- & --- & --- & --- \\
\hline 5 & 0.00 & --- & --- & --- & --- & --- & --- & --- & --- & --- & --- & --- \\
\hline 6 & 0.00 & --- & --- & --- & --- & --- & --- & --- & --- & --- & --- & --- \\
\hline 7 & 0.00 & --- & --- & --- & --- & --- & --- & --- & --- & --- & --- & --- \\
\hline 8 & 0.00 & --- & --- & --- & --- & --- & --- & --- & --- & --- & --- & --- \\
\hline 9 & 0.00 & --- & --- & --- & --- & --- & --- & --- & --- & --- & --- & --- \\
\hline 10 & 0.00 & --- & --- & --- & --- & --- & --- & --- & --- & --- & --- & --- \\
\hline 11 & 0.00 & --- & --- & --- & --- & --- & --- & --- & --- & --- & --- & --- \\
\hline 12 & 0.00 & --- & --- & --- & --- & --- & --- & --- & --- & --- & --- & --- \\
\hline 13 & 0.00 & --- & --- & --- & --- & --- & --- & --- & --- & --- & --- & --- \\
\hline 14 & 0.00 & --- & --- & --- & --- & --- & --- & --- & --- & --- & --- & --- \\
\hline 15 & --- & --- & --- & --- & --- & --- & --- & --- & --- & --- & --- & --- \\
\hline 16 & --- & --- & --- & --- & --- & --- & --- & --- & --- & --- & --- & --- \\
\hline 17 & --- & --- & --- & --- & --- & --- & --- & --- & --- & --- & --- & --- \\
\hline 18 & --- & --- & --- & --- & --- & --- & --- & --- & --- & --- & --- & --- \\
\hline 19 & --- & --- & --- & --- & --- & --- & --- & --- & --- & --- & --- & --- \\
\hline 20 & --- & --- & --- & --- & --- & --- & --- & --- & --- & --- & --- & --- \\
\hline 21 & --- & --- & --- & --- & --- & --- & --- & --- & --- & --- & --- & --- \\
\hline 22 & --- & --- & --- & --- & --- & --- & --- & --- & --- & --- & --- & --- \\
\hline 23 & --- & --- & --- & --- & --- & --- & --- & --- & --- & --- & --- & --- \\
\hline 24 & --- & --- & --- & --- & --- & --- & --- & --- & --- & --- & --- & --- \\
\hline 25 & --- & --- & --- & --- & --- & --- & --- & --- & --- & --- & --- & --- \\
\hline 26 & --- & --- & --- & --- & --- & --- & --- & --- & --- & --- & --- & --- \\
\hline 27 & --- & --- & --- & --- & --- & --- & --- & --- & --- & --- & --- & --- \\
\hline 28 & --- & --- & --- & --- & --- & --- & --- & --- & --- & --- & --- & --- \\
\hline 29 & --- & --- & --- & --- & --- & --- & --- & --- & --- & --- & --- & --- \\
\hline 30 & --- & --- & --- & --- & --- & --- & --- & --- & --- & --- & --- & --- \\
\hline 31 & --- & --- & --- & --- & --- & --- & --- & --- & --- & --- & --- & --- \\
\hline TOTAL & --- & --- & --- & --- & --- & --- & --- & --- & --- & --- & --- & --- \\
\hline MEAN & --- & --- & --- & --- & --- & --- & --- & --- & --- & --- & --- & --- \\
\hline MAX & --- & --- & --- & --- & --- & --- & --- & --- & --- & --- & --- & --- \\
\hline MIN & --- & --- & --- & --- & --- & --- & --- & --- & --- & --- & --- & --- \\
\hline MED & --- & --- & --- & --- & --- & --- & --- & --- & --- & --- & --- & --- \\
\hline
\end{tabular}




\section{Appendix. Discharge-Reporting and Load-Calculation Methods}

This appendix further defines the methods used for reporting discharge data and constituent-concentration data and the methods for calculating instantaneous constituent loads. Discharge and water-quality-data values are rounded off to the number of significant figures that best describe the precision of the measurement.

Discharge data.-Appendix Table 1 shows the number of significant figures and rounding limits for the range of discharges used in this study. Discharges measured by current meter or float-measurement techniques follow guidelines for measured discharges. Discharges determined by streamflow rating or by averaging follow guidelines for daily-mean discharges (Sauer, 2002). Measured discharges may have more significant figures because they are considered more precise than averaged discharges.

Table A1. Significant figures and rounding limits for measured, streamflow-rating, and averaged discharges. $\left[\mathrm{ft}^{3} / \mathrm{s}\right.$, cubic feet per second; <, actual value is less than shown; , actual value is greater than or equal to value shown]

\begin{tabular}{|c|c|c|c|c|}
\hline \multirow[b]{2}{*}{ Range of discharge ( $\left.\mathrm{ft}^{3} / \mathrm{s}\right)$} & \multicolumn{2}{|c|}{ Measured discharge } & \multicolumn{2}{|c|}{ Streamflow-rating and averaged discharges } \\
\hline & Significant figures & Rounding limit & Significant figures & Rounding limit \\
\hline$<0.10$ & 2 & thousandths & 1 & hundredths \\
\hline 1.0 and $<10$ & 3 & hundredths & 2 & tenths \\
\hline 10 and $<100$ & 3 & tenths & 2 & units \\
\hline
\end{tabular}

Calculation of loads.-Appendix Table 2 shows the conversion factors used for determining constituent loads. Constituent loads for all analyses are reported as pounds per day (lbs/day) or tons per day (tons/day). All loads are the product of constituent concentration multiplied by associated discharge and the appropriate conversion factor (equation 1). Concentrations are reported in milligrams per liter $(\mathrm{mg} / \mathrm{L})$. Four significant figures are used for the conversion factors; however, the load value is reported with the lesser number of significant figures of the values of concentration and discharge.

$$
Q(C) K=L
$$

Where

$$
\begin{aligned}
& \mathrm{Q}=\operatorname{discharge}\left(\mathrm{ft}^{3} / \mathrm{s}\right) \\
& \mathrm{C}=\text { constituent concentration }(\mathrm{mg} / \mathrm{L}) \\
& \mathrm{K}=\text { conversion factor } \\
& \mathrm{L}=\text { constituent load }\left(\text { lbs } / \text { day },{ }^{\text {tons }} / \text { day }\right)
\end{aligned}
$$

Table A2. Conversion factors for computing daily loads from constituent concentration and discharge $[\mathrm{mg} / \mathrm{L}$, milligrams per liter; lbs/day, pounds per day]

\begin{tabular}{ccc}
\hline Unit of concentration & Conversion factor $^{\mathbf{a}}$ & Load unit $^{\text {(n) }}$ \\
\hline $\mathrm{mg} / \mathrm{L}$ & 5.394 & $\mathrm{lbs} / \mathrm{day}$ \\
$\mathrm{mg} / \mathrm{L}$ & 0.002697 & tons/day \\
\hline
\end{tabular}

${ }^{\mathrm{a}}$ All conversion factors are based on discharge in cubic feet per second. 
